USP - Universidade de São Paulo

ECA - Escola de Comunicações e Artes

CAC - Departamento de Artes Cênicas

\title{
"CALEIDOSCÓPIO DIGITAL"
}

Contribuições e renovações das tecnologias da imagem na cena contemporânea

Tese apresentada à banca examinadora da Escola de Comunicações e Artes, da Universidade de São Paulo, como requisito para obtenção do título de Doutor em Artes Cênicas.

Nível: Doutorado

Marcelo Denny de Toledo Leite

Orientação:

Profa. Dra. Sílvia Fernandes Telesi 


\section{Banca Examinadora}




\section{Agradecimentos}

Aos mestres do passado: Afonso Barone, Joaquim Gama, Newton de Souza, Elizete Gomes, Wander Ferreira e Jorge Vermelho;

Aos mestres do presente: Clóvis Garcia, Luís Fernando Ramos, Antônio Araújo, Antônio Januzelli, Maria Lúcio Pupo e em especial a Marcos Bulhões;

Aos amigos de sempre: Fábio Mendes, Edimar Otávio, Alberto Santiago, Wilson

Maximiano, Edson Sansil, Márcio Pimentel e em especial a Marcelo Henrique;

A minha orientadora Profa. Dra. Silvia Fernandes, pela sabedoria e carinho;

A minha família em especial a minha mãe, Denir Henriqueta, que sempre me apoiou.

\section{Dedicatória}

Dedico este trabalho a todos que dizem e aos que aceitam o Sim

Tudo no mundo começou com um sim.

Uma molécula disse sim a outra molécula e nasceu a vida

Clarice Lispector 


\section{Resumo}

Qual é o lugar das imagens tecnológicas na cena hoje? O que muda com a inclusão das linguagens cinematográficas, videográficas e agora a internet nas artes cênicas na contemporaneidade? Quais seriam as contribuições desses cruzamentos entre o teatro, a performance art, a ópera e a dança, quando utilizam as linguagens audiovisuais? Nesse estudo pretendo levantar uma reflexão sobre essas contribuições, dividindo em três pilares de análise: as somas das imagens tecnológicas em relação ao Espaço, depois sobre o Tempo e finalmente sobre o Corpo.

Sempre utilizando exemplos da cena contemporânea, mas também recorrendo aos pioneiros nessa ativade, mostrarei como os recursos eletrônicos e digitais mudaram a forma de fazer e ver como potências cênicas hoje, e como podem dialogar com novas ideias de espacialidade, temporalidade e corporificação quando se apresenta: efeitos de alteracão, efeitospoéticos, de memória e também como a presença.

Uso como exemplos de análise também trabalhos que eu desenvolvi como diretor e diretor de arte/cenógrafo nos últimos quatro anos, bem como exemplos de artistas e grupos nacionais e internacionais. Os resultados obtidos podem abrir perspectivas para professores de artes cênicas em geral, assim como para diretores, cenógrafos, profissionais do cinema e do vídeo, artístas das mídias e outras pessoas que investiguem a encenação contemporânea e seu universo híbrido. 


\section{Abstract}

Which is the place of technologic images in the theatre today? What is changed due to inclusion of cinematographic, videographic and internet languages nowadays? Which contributions would be from these intersections between theatre, performance art, opera and dance when we use audiovideo languages? In this study, I wish to raise a reflection on those contributions, dividing into three pillars of analysis: The sums of the technologic images in relation to Space, on Time and then finally on the Body.

Always using examples of the contemporary scene, but also using the pioneers in this activity, I will show how the electronic and digital resources like scenic powers today have changed the way of doing and seeing the theatre, and how they can engage with new ideas of spatiality, temporality and embodiment when they present effects of changing, poetry, memory and also presence.

Using as examples of analysis also works that I developed as a director and art director / designer in the last four years, as well as examples of artists and national and international groups. The results may open perspectives for teachers of performing arts in general, as well as directors, designers, cinema's and video's professionals, artists from the media and others who investigate contemporary staging and its hybrid universe. 


\section{Sumário}

Introdução Pág.8

1. Capítulo 1 - A Imagem-Espaço: os recursos da tecnologia da imagem na criação de novas espacialidades cênicas Pág.24

1.1 Os primeiros visionários Pág. 32

1.2 Meyerhold e a cineficação interna e externa Pág.34

1.3 O espaço-imagem no expressionismo Pág.39

1.4 A experimentação na Bauhaus Pág.40

1.5 Erwin-Piscator e O Teatro-Filme Pág.44

1.6 A Lanterna Mágica de Joseph Svoboda Pág.50

1.7 La Fura dels Baus Pág.52

1.8 La Fura dels Baus - Óperas Pág. 64

1.9 Outras óperas Pág.67

1.10 Novos formatos Pág.69

1.11 Novos formatos - No Brasil Pág.77

1.12 Espaços impossíveis Pág.84

1.13 A cena no ciberespaço Pág.90

2. Capítulo 2 - A Imagem-Tempo: A imagem tecnológica na criação de efeitos de tempo e memoria: passado e futuro Pág.97

2.1 Um primeiro olhar Pág.97

2.2 A imagem-tempo nos primeiros Happenings Pág.98

2.3 As inovações de Nam June Paik Pág.100

2.4 A imagem-tempo invade o teatro e a dança Pág.103

2.50 tempo na cena de Robert Lepage Pág.105

2.6 Experiências do grupo Cena 11 (Brasil) Pág.119

2.7 Outras experiências brasileiras Pág.120

2.8 Experiências em 'Devorando Quixote' Pág.124

2.9 A imagem digital como tempo-memória Pág.125

3. Capítulo 3 - A Imagem-Corpo: As tecnologias da imagem na construção de efeitos de presença do ator / performer Pág.128

3.1 Primeiras reflexões Pág.128

3.2 A fantasmagoria, primórdios dos efeitos de presença Pág.132

3.3 A dança (multimídia) de Loïe Fuller Pág.135

3.4. O "Teatro do Futuro" de Robert Edmond Jones Pág.136

3.5 O corpo vídeo Pág.140

3.6 As imagens tecnológicas e o corpo Pág.141

3.7 Os corpos fantásticos de Tony Oursler Pág.142

3.8 As múltiplas faces de Denis Marleau Pág.145

3.9 O hibridismo do Studio Azzuro Pág.147

3.10 Marcel-li Antunez Roca e a imagem como interface para o corpo Pág.148

3.11 A dança telemática Pág.154

3.12 Experiências brasileiras Pág.159

3.12.1 As vídeocriaturas de Otavio Donasci Pág.159

3.12.2 Os rituais eletrônicos de Renato Cohen Pág.163

3.12.3 A tecno-dança do grupo Cena 11 Pág.165

3.12.4 Outras experiências brasileiras Pág.178 
3.13 Sobre interação entre corpo e imagem tecnológica Pág.184

4. Considerações Gerais Pág.186

5. Relação de Figuras Pág.195

6. Referência Bibliográfica Pág.198 


\section{Introdução}

A arte não tem necessidade de certezas; ela não tem de se preocupar em saber aonde vai; ela vai em direção a si mesma, simplesmente porque ela é e porque é levada naturalmente a se lançar e a se desdobrar. Nietzsche

Qual é o lugar das novas tecnologias para as artes na atualidade? Qual o lugar das tecnologias nas artes cênicas? Como podemos fazer uso das imagens tecnológicas em diálogo com os atuantes? Quais seriam as contribuições possíveis entre o cruzamento das artes audiovisuais (virtuais e não presentes) com as artes cênicas (presença real)? Quais os tipos de entendimento que podemos e devemos ter sobre a simbiose entre linguagens que a cada dia parecem ser mais miscigenadas e criativas?

Perguntas como estas me moveram a iniciar esse estudo e refletir, distinguir um levante estético das imagens tecnológicas, aqui imagens projetadas vindas do cinema/vídeo em cena. Toda forma de arte faz uso de algum tipo de tecnologia. Fotografia e cinema são exemplos óbvios, mas as artes plásticas também se valem de dispositivos tecnológicos, como pincéis, pigmentos e cinzéis.

Mesmo as artes do corpo empregam um estudo característico de tecnologias ou, antes, tecnologias próprias. Porém nesse estudo investigarei os prismas mais estéticos das tecnologias audiovisuais típicas dessa época das telas, em que desde celulares com recursos de captação e edição de vídeo até projetores cada vez menores, computadores (hardwares) e uma infinidade de programas (softwares), são a cada dia mais facilitados, simples e fáceis de adentrar.

Simples por um lado, complexas por outro, as criações com meios digitais são, acima de tudo, uma escolha que abrange a amplitude das relações entre tecnologia e cultura; e nesse sentido as variáveis proporcionam novos paradigmas de feitura, leitura e percepção daquilo que antes era a arte da presença e agora requer o virtual, mudando registros, re-poetizando cenas e mundos à medida que incorporam mídias cada vez mais híbridas.

Da cineficação das artes cênicas até as possibilidades de internetização, pretendo criar, mais que um panorama, um estudo sobre o cruzamento das tecnologias da cena (aqui as imagens) a partir de três pilares de entendimento e uso - 
no espaço, no tempo e no corpo. Passarei, assim, por análises de artistas e grupos atuais que incorporam cada vez mais as tecnologias da imagem em seus espetáculos em busca da abertura de novos caminhos.

Diante de tantas possibilidades que o processo de criação na cena tecnológica (digital) proporciona, há um ponto particular de questionamento: Por que utilizar as tecnologias? Qual o lugar da interatividade tecnológica com o público? O que muda nesse cruzamento? O que pode mudar?

Tecnologia, maquinário e efeitos especiais no palco sempre fizeram parte da experiência do teatro, da performance e outras artes cênicas, como um recurso utilizado, na maioria das vezes, para solucionar e viabilizar ações que não poderiam ser realizadas em cena, como explosões, catástrofes e fenômenos da natureza.

Sejam elas mecânicas, eletrônicas ou digitais, as tecnologias, usadas como fins em si mesmas, também promoveram deslumbramento e fantasia. A perda do fôlego pelo terror e assombro em sua operação se torna um aspecto significativo da experiência nas artes cênicas como, por exemplo, o intenso prazer do momento "agora vê, agora não vê" num efeito especial de ilusão ou a transformação inexplicável de um local em outro, como mágica, ao piscar de luzes e efeitos sonoros que acompanhavam os personagens nos teatros barrocos.

Em momentos significativos na história do teatro e da performance, a tecnologia tem servido como uma representação e celebração na habilidade e arte em entreter, refletir e expor a magia. Ao mesmo tempo que a reverencia, a cena a usa como suporte técnico e estético.

Na utilização ostensiva da tecnologia pode habitar o poder de uma nação, de um monarca ou de um Estado, o poder do proprietário do teatro ou os meios de apresentação, de forma que o recurso contém simbologia de poder e autoridade quando presente em cena.

Segundo o Dicionário Houaiss da Língua Portuguesa (2001, p.2683), a palavra tecnologia vem do grego tekhnologia, junção de tekchno (arte, indústria e ciência) e logia (linguagem, estudo), ou seja, é a linguagem ou estudo da arte e da ciência.

Tão antigas quanto a espécie humana, da engenhosidade originaram-se as mais diferenciadas tecnologias e o uso do raciocínio tem garantido um processo crescente 
de inovações. Atualmente é comum encontrar na literatura referências como tecnologias da informação, tecnologia industrial, tecnologia social, dentre outras.

Para facilitar a compreensão do que é tecnologia empresta-se aqui a concepção de CARVALHO que defende que a tecnologia não é apenas um recurso instrumental, e sim um processo que contempla aspectos socioculturais envolvidos na sua produção.

\begin{abstract}
Tal concepção centraliza tecnologia como um fenômeno que se manifesta na sociedade moderna que se caracteriza pela existência do trabalho produtivo (...) porque na produção das condições materiais de vida, necessária a qualquer sociedade, é imprescindível a criação, apropriação e manipulação de técnicas que carregam em si elementos culturais, políticos, religiosos e econômicos, constituintes da concretude da existência social. Deste ponto de vista, tecnologia está intrinsecamente presente tanto numa enxada quanto num computador. (CARVALHO, et.al, 2005)
\end{abstract}

Para além dos deslumbramentos com as "maravilhas da tecnologia" e do ceticismo frio, esta pesquisa, examina o universo híbrido das linguagens artísticas num recorte tecnológico e imagético, suas práticas e seus praticantes; e analisa as tendências teóricas e tecnológicas que emergiram com o aparecimento de novas tecnologias das imagens em cena, ou seja, a congruência entre as artes audiovisuais e as artes cênicas.

O uso de formas aparentemente frias e vazias, sobretudo nas artes, meramente técnicas, das novas tecnologias, provoca transformações profundas, movimentos de aceleração e corrosões de conceitos: sinapses poéticas, novas formas de ver e fazer, fruição do sublime.

Reagimos com sentimentos contraditórios perante o novo e diante de tecnologias não incorporadas, oscilando entre atração e repulsa, euforia e depressão. Nas artes cênicas, acredito no sublime tecnológico presente quando a máquina se transforma em poesia.

Para exemplificar, me permito referenciar diretamente o mito de Frankenstein, de Mary Shelley, como ícone da técnica tornada arte, que se afirma em sua atemporalidade e sua modernidade. $\mathrm{O}$ monstro criado a partir de partes mortas e reanimado artificialmente transcende seu mestre e seu tempo, ou seja, a tecnologia torna-se viva, criativa, sublime; e pode até superar as capacidades e habilidades de seu criador, catapultando a obra-monstro pra um território desconhecido. 
Estou cada vez mais convencido de que 'poesia' (do grego poíesis = ação de fazer algo) é a única palavra capaz de dar conta da dimensão, complexidade e fluidez da criação artístico-científica no Universo em expansão das novas tecnologias. Estamos fadados à poesia. (VALLIAS, 2007 p.121)

A máquina capaz de abrir novas descobertas, o super-corpo animado pela tecnologia do monstro de Frankenstein, reavalia as dimensões científicas e tecnológicas como possibilidade libertadora. A criatura monstruosa foi animada pelo uso da eletricidade e rompeu barreiras definidoras de natureza versus ciência.

Se o homem e sua cognição forem vistos como elementos pertencentes e intrínsecos à sua evolução, a tecnologia ganhará o sentido essencial para a compreensão desta pesquisa, de forma que não serei por demais panorâmico ao analisar a abordagem genérica das artes cênicas + tecnologia, mas sim me direcionarei ao fragmento artes cênicas + tecnologias da imagem, ao qual denomino "contribuições e renovações das tecnologias da imagem na cena contemporânea" devido à ampla utilização de recursos cinematográficos e videográficos presentes nas encenações atuais.

Para discutir essa tecnologia, como a confluência entre o cênico presente e o cênico gravado/filmado/projetado/televisionado, será necessário remover equívocos sobre o entendimento comum de tecnologia, observar a face oculta deste mito e refletir sobre sua existência real, elucidando o pensamento que opera em suas entranhas.

As somas e cruzamentos de artes e linguagens e outros campos do saber tem sido umas das principais características das artes contemporâneas, de maneira que as fronteiras se romperam, gerando uma mistura que fomenta um cenário cada vez mais híbrido de narrativas enviesadas, mixadas e até caóticas.

Entender que natureza e cultura estão entrelaçadas e áreas como mente-corpo, natural-artificial, ou real-virtual, entre outras, não mais devem legislar sobre estruturas separatistas e dualistas em que vivemos hoje, faz-se obrigatório para contextualização do cenário de artes cênicas em que me detenho neste estudo.

O mito do monstro tecnicista de Mary Shelley toma forma mutante, caleidoscópica de possibilidades, visto que o campo de diálogo entre arte e tecnologia, 
arte e mídia, pode ser muito vasto ao considerar o desenvolvimento exponencial das novas tecnologias audiovisuais na cena contemporânea.

Por mídia compreendo todo sistema de comunicação que permita a uma sociedade realizar as funções essenciais da conversação, uma comunicação à distância de mensagens e conhecimentos e a ritualização de práticas culturais e políticas.

Pretendo apresentar o uso de telas de imagens nas artes cênicas elucidando o cruzamento entre linguagens tão complexas (a tradição teatral, incluindo performance e dança, e o audiovisual, considerando o cinema e a nova linguagem videográfica) a partir da trajetória evolutiva do mecânico ao eletrônico, chegando ao analógico e agora ao digital; um desdobramento mágico, dinâmico e ilimitado.

A tradição teatral, durante séculos, deteve reinado soberano com seu ator e texto falado. Com a chegada da fotografia e do cinema, vimos o estatuto dessa e outras formas de arte evoluírem. Coincidentemente, na mesma época, surgem os encenadores teatrais. No início, o cinema baseou-se nas formas de produção de criações teatrais até que, aos poucos, foi se firmando como divertimento e, mais tarde, como arte, estabelecendo seus próprios códigos e especificidades.

\footnotetext{
Não obstante, experimentamos um mal-estar ao falar do teatro como uma mídia, pois persistimos em ver nele uma reunião de artes (literatura, pintura, música) na medida em que não o concebemos como uma arte autônoma ou sintética. Assim, quando se faz referência ao teatro e as mídias, sugere-se, implicitamente, não apenas que o teatro não é uma mídia e que ele precede e domina estas últimas, mas sobretudo, que as mídias técnicas, as tecnologias novas ou antigas (vídeo, filme, projeção de imagens) "invadem" o espaço inviolável da representação, ela própria limitada ao desempenho do ator, até à escuta do texto. Esse desprezo, essa atitude de defensiva, testemunham uma concepção essencialista do teatro, tal como, por exemplo, a de Grotóvski, Kantor, Brook ou Mnouchkine. Porém, o teatro não tem sempre recorrido às tecnologias de toda espécie? E estas, estão tão afastadas da noção de mídia? (PAVIS, 2010, p.174)
}

Walter Benjamim em 'A obra de arte na era de sua reprodutibilidade técnica' afirma que a nova linguagem do cinema alterou a maneira de ver e perceber as coisas e faz várias alusões ao cinema como uma reprodução do trabalho teatral, de forma que o que torna o cênico irreprodutível é exatamente seu caráter efêmero de evento não durável. 
No entanto, o uso da tecnologia foi incorporado ao teatro, não somente como meio de reprodução, mas também como processo de criação e encenação teatrais, transformando a própria reprodução num elemento visto em cena, 'ao vivo'.

O que desencadeou, como se podia prever, novas formas de ver e produzir uma obra de arte, assim como a mudança de paradigma no modo como o mundo consome as mídias. Como aponta o pesquisador Henry Jenkins

as velhas mídias estão na UTI, mas na verdade as velhas mídias não morreram. Mas nossa relação com elas é que morreu. Estamos numa época de grandes transformações, e todos nós temos três opções: temê-las, ignorálas ou aceitá-las. Se optarmos por ignorá-las, perderemos, como artistas cênicos, o "bonde da história". Se optar por temê-las, poderá ser um sinal de enfrentamento e de diálogo com esse hibridismo caótico e por vezes atormentador, mas não menos rico e profundo. (JENKINS, 2008, p. 8)

Como afirma o diretor inglês Peter Greenaway 'toda forma de arte pode e deve ser reinventada'. Se optarmos por aceitar essa informação, então esse estudo poderá ser de grande valia para a compreensão dos desafios a serem enfrentados e das oportunidades que surgirem.

As antigas formas da produção cênica e da produção tecnológica, em constante evolução, promovem novos níveis de participação, elaboração e confecção das artes cênicas, incorporando o aparato das tecnologias, cada vez mais acessível, potencializando discursos estéticos urgentes. Novos mecanismos de mediação estão sendo implementados para estreitar o espaço entre o virtual e real, entre a presença e o efeito de presença.

O universo midiático se abre para as artes cênicas: novas práticas são adotadas para atender as mesmas audiências fragmentadas num território novo, complexo, ramificado e interligado. Para além do niilismo da era digital, num jogo de interpelações de linguagens e laços artísticos cada vez mais estreitos, em que o cruzamento e a miscigenação são regras, temos atualmente, a partir das idéias do filósofo francês Gilles Delleuze ${ }^{1}$, a ideia de rizoma ${ }^{2}$, que afeta as áreas e as relações de intermídia, um labirinto digital.

\footnotetext{
${ }^{1}$ Delleuze (1925-1995), filósofo francês formado pela Universidade de Paris 'Sourbonne', fez parceria com Félix Guattari, encontro que resulta com uma longa e rica, e considerada por muitos, controversa colaboração. Foi vinculado aos denominados movimentos pós-estruturalistas, categorizações que o próprio Gilles questionava pelo que trazem ainda da visão e luta pelo idêntico. Suas teorias a cerca da
} 
A aplicação de novas mídias às artes cênicas é extremamente diversa e essa contaminação cria um tipo de ação estética descentralizada, em que o cinema/vídeo se potencializa como linguagem a partir do contato com novas linguagens.

Com sínteses desse tipo podemos verificar o circuito dos meios expressivos da arte sendo contaminados pelo conglomerado sígnico que representa o audiovisual. Além das probabilidades interativas abertas pelas redes de computadores, elas possibilitam a criatividade compartilhada nas improvisações textuais e telemáticas em tempo real; o que refaz paradigmas tão caros às artes cênicas como o de presença.

A revolução tecnológica, que no modo de fazer e ver não é previlégio apenas do teatro, se desenvolve com ferramentas que permitem uma melhor (mais fácil e rápida) realização de tarefas rotineiras à estrutura da filmagem, afetando profundamente a produção e o resultado cinematográfico, possibilitando novas e intensas experiências interativas de imagem.

Analisando as obras dos cineastas James Cameron, Wim Wenders e Peter Greenaway, observam-se que eles destroem convenções atuais oferecendo ao receptor um tipo de experiência visivelmente diferente, como a definição de imagem, códigos de edição. O discurso narrativo adquire uma forma amplamente definida pelas tecnologias e técnicas eletrônicas e digitais.

Assim, a percepção do filme alcança novo caráter para realizar o efeito de irrealidade, ou talvez o 'efeito de nova realidade', produzidos por simulação e oferecendo novas formas de experiências e de compreensão. Por outro lado, essas renovações no cinema e vídeo acabam por chegar muito rápido às práticas teatrais e performáticas, alimentando as artes cênicas e dinamizando um rizoma estético que se

diferença e da singularidade nos desafiam a pensar em temas como rizoma, ontologia da experiência, a teoria do que fazemos, a virtualidade e a atualidade.

${ }^{2}$ Para a botânica rizoma é o conceito que permite analisar o caule de planta como uma expansão que une os sucessivos brotos ilimitadamente expansíveis mantendo potencialidade de uma nova planta em cada um de seus 'nós' ou pseudo bulbos, a grama é um exemplo bastante conhecido de planta rizomatica por não ter raízes únicas, todas estão interligadas. Na teoria filosófica, Delleuze e Guattari, com base no conceito botânico, apresentam possibilidades interessantes ao embasamento epitemológico para análise de sistemas a partir do conceito aberto que o caule de planta permite a pensar o mundo moderno e a educação. Ambos autores adotam os conceitos de expansão ilimitada com descrições das condições discursivas e propostas topológicas de raiz e radícula, em que cada nó ou desdobramento conceitual possui a essência do conceito que o precede, sem - no entanto - ser uma cópia do conceito original. 
nutre automaticamente, gerando um desenvolvimento muito rápido, tanto técnico como estético.

O teatro em toda sua trajetória configura-se como arte integrativa e colaborativa que potencialmente incorpora todas as artes: a música, a dança, a pintura, a escultura, etc. Essa característica 'multimídia', devido à junção por excelência de todas as artes, provoca em determinados territórios a percepção da 'intermídia', da 'transmídia' e ainda de 'realidade expandida'.

A "orgia rizômica" de Deleuze parece se alimentar da soma dos sentidos, percepção de outras narrativas e fragmentação, possuindo o poder de afetar e contaminar irreversivelmente a outra linguagem em diálogo. Característica presente no processo audiovisual em que uma imagem soma seus sentidos aos sentidos de outras linguagens (como as cenografias em vídeo instalações e múltiplas possibilidades) de tal forma que uma linguagem não pode mais ser dissociada da outra.

\subsection{Multimídia e intermídia}

Exceto ao se referir à informática, com freqüência o termo 'multimídia' é aplicado indiscriminadamente a qualquer performance que use algum tipo de vídeo, filme ou CGI - computer generated imagery (imagens geradas por computador) em performance ao vivo. Mas me proponho apresentar as diferenças terminológicas.

A produção de um texto Shakespeareano pode ocasionalmente utilizar projeções de vídeo para composição do cenário ou para dinamizar a ação no palco, como também pode contar uma produção de alta tecnologia, em que as ações dos performances aconteçam com base na interação entre eles no palco e na tela.

No primeiro formato, o vídeo pode ser considerado como utilizado de maneira análoga ao modo que a iluminação, o cenário e os figurinos eram usados para situar a ação e sugerir uma abordagem interpretativa particular. Nesse caso, o vídeo era uma opção dentre os muitos aparatos que coletivamente davam suporte a performances, configurando um trabalho 'multimídia'.

No segundo, em que há uma interação mais extensiva entre performers e noções remodeladas do personagem e do atuar, em que nem o material ao vivo nem o 
material gravado fariam muito sentido utilizados independentemente, a interação entre mídias altera substancialmente a forma como essa respectiva mídia funciona convencionalmente e convida a uma reflexão sobre sua natureza e seus métodos, configurando um trabalho que chamaremos de 'intermídia'.

$\mathrm{Na}$ prática, as terminologias não são limítrofes. Podemos encontrar um trabalho com predominância 'multimidial'. De modo comercial, uma mera soma entre as mídias, com pequenas abordagens 'intermidiais' buscando pesquisa e correlação entre as mídias. Contudo, considero relevante compreender o poder informativo dessas distinções ao analisar práticas ou trabalhos pessoais.

\begin{abstract}
Eu sugeriria que o uso de filme no teatro era inicialmente mais multimidial, mas interações crescentemente mais complexas entre teatro e outras mídias a partir dos anos 60 deixou uma emergência de trabalhos genuinamente intermídias. Apesar disso, um uso tecnológico mais sofisticado da projeção de vídeo no teatro "mainstream" reflete mais uma abordagem multimidial; como em Mesure for Mesure (Medida por Medida) e The Woman in White, por exemplo, são descritos mais apropriadamente como multimidial. A colaboração de Dudley a Terry Johson em Hitchock Blonde exemplifica trabalhos que inicialmente parecem ser mais ambíguos. Uma exploração esperta do desejo e um olhar cinemático atento, intercala cenas em que um acadêmico e sua aluna reconstroem um dos primeiros filmes de Hitchcock com cenas de "flashbacks" envolvendo Hitchcok e a dublê de corpo de Janet Leigh na cena do chuveiro em Psycho. Projeções são usadas substancialmente como cenário e para mostrar reconstruções de momentos do filme; e algumas vezes o vídeo também evoca fantasias subjetivas dos personagens. Enquanto, mantendo seus temas, a atmosfera geral é cinemática, e o curto filme "reconstruções" sugeri persuasivamente os primeiros filmes de Hitchcock, existe uma pequena interação ativa entre o palco e o material projetado e os temas sobre o filme são trabalhados pelas premissas na ação e diálogos. Apesar de algumas similaridades iniciais com o trabalho intermidial, este emerge em última instância como uma obra multimidial. (GIESEKAM, 2007 p.129)
\end{abstract}

Essa extremidade das artes cênicas refere-se a sua expansão como dispositivo e também a sua ampliação no espaço sensório. Em muitas dessas estratégias criativas, trata-se de observar a saída do cinema/vídeo do plano da tela, do monitor de TV, para estender as experiências ao circuito de novas possibilidades de projeção.

Suportes que mudarão a recepção, como também a textura das imagens e, claro, a soma de imagens digitais e reais produzindo manifestações dialógicas sem, contudo, deixar de existir com seus atributos particulares de código e linguagem. 
Em 1849, no ensaio 'Outlines of the Artwork of the future', Richard Wagner desenvolve o conceito de obra de arte total (Gesamtkunstwerk ${ }^{3}$ ) para se referir ao drama do futuro que, longe de se ater às segmentações e especificidades de cada linguagem, seria fruto da fusão de todas as artes.

No início da década de 1920, László Moholy-Nagy, resgatando o princípio da obra de arte total wagneriana, propõe um novo tipo de teatro: um teatro total que, em vez de centrar-se na atuação do ator e na hierarquia clássica texto/ator/narrativa, pudesse enfatizar os demais aspectos da peça teatral, como cenário, iluminação e figurino, dando maior importância às inter-relações de seus elementos constitutivos.

A concepção de Wagner é central para a linhagem do teatro contemporâneo, tanto em sua recomendação em favor do grande espetáculo teatral como em seu paradigma de convergência, ao unir a Gesamtkunstwerk aos entendimentos contemporâneos do computador moderno como uma "meta-mídia" que unifica todas as mídias (texto, imagem, som, vídeo, etc) dentro de uma única interface.

A própria versão de Wagner de Gesamtkunstwerk, como está expressa em seu épico music-dramas, desdenhou daqueles que descreveram seu trabalho como ópera e empenhou-se não apenas numa síntese de formas de arte, mas também ao objeto de desejo em muitos esforços da multimídia: a imersão do espectador. Atualmente desenvolvemos formas cênicas e cinematográficas em que se busca um maior nível de interatividade e imersão, como por exemplo em performances no Second Life ou no Cinema 3D.

A ciência mais recente, especialmente no que se refere a questões de acaso e caos, fornece um estoque de metáforas e percepções de relações que estão disponíveis para se entender a natureza efêmera e impermanente da performance ao vivo.

Dessa forma, a tecnologia nas artes cênicas passa de suporte técnico, gradualmente, para um suporte estético e é desses suportes estéticos na cena moderna que nos ocuparemos a partir daqui.

\footnotetext{
${ }^{3}$ Gesamtkunstwerk ou obra de arte total é um termo da língua alemã atribuído ao compositor alemão Richard Wagner e refere-se a uma apresentação de ópera que conjuga música, teatro, canto, dança e artes plásticas. Wagner acreditava que na antiga tragédia grega esses elementos estavam unidos, mas, em algum momento separaram-se. Criticava o atual estado da ópera, que dava muita ênfase a música sem conter nenhum drama de qualidade. O termo é usado com freqüência, principalmente na Alemanha, para descrever qualquer integração de múltiplas expressões artísticas diferentes
} 
A influência da tecnologia pode ser vista como uma força que gera uma genuína reavaliação de modelos e um repensar das técnicas e paradigmas artísticos e de comunicação. $O$ século $X X$, como palco das imensas transformações da tecnologia de forma geral, não por acaso, é o período em que as artes cênicas flertaram com o eletrônico, o analógico e, finalmente, o digital.

Um dos campos mais ricos de investigação das mídias audiovisuais no cenário contemporâneo diz respeito à sua confluência com o mundo do teatro, da dança e da performance. Já nos anos 60, experiências de J. Svoboda, John Vage, Merce Cunningham, Robert Rauschenberg, Nam June Paik, Jasper Johns, anunciavam o cenário do teatro midiático contemporâneo, que se consolidaria nos anos 80 e 90, formalizando uma cena demarcada por novas escrituras.

Essas escrituras incorporam a dramaturgia de processo, as hibridizações entre textualidades, as imagens e os acontecimentos, a atuação performativa e os procedimentos de midiatização com veiculação multimídia e a utilização de novas mídias digitais.

Para além dos ciber-cenários construídos geralmente por meio de projeção, os cruzamentos dessas mídias, às vezes, apontam e refletem o próprio uso em si num jogo metalingüístico em que a tecnologia está em cena para ser analisada, criticada e refletida sob novas químicas e novos pontos de vista.

\footnotetext{
Nós reanimamos textos teatrais clássicos, introduzindo-os em novos meios de expressão, e depois remanejando-os dentro do contexto caótico da cultura global contemporânea (...) como o espetáculo Jump Cut (Faust), de 1997, com textos de Jesurun e montangem visivelmente influenciada pelo Wooster Group, que envolveu cenas de vídeo interativas e sofisticadíssimas nas quais personagens do Fausto de Goethe faziam cenas de um filme de Fausto (1926), do tempo do cinema mudo, de F.W. Mornau, e reagiam ao vídeo gerado por uma câmera colocada no palco (DIXON, 2007 p.94).
}

Ainda hoje, devido à tradição, existe muito preconceito sobre a junção dessas linguagens midiáticas e o teatro. Cito John Cage, já que 'não é necessário renunciar ao passado ao entrar no porvir. Ao trocar as coisas, não é necessário perdê-las'. Assim aponto que não é necessário que exista tecnologia para se fazer um bom teatro hoje, nem nos moldes mais experimentais ou vanguardistas. 
Porém, não podemos mais isolar as artes. O mundo hoje vive o pico da chamada revolução tecnológica em que nossa percepção de mundo, ritmos, aspirações e formas de pensar estão profundamente modificadas pela tecnologia.

Revoluções políticas no oriente médio são deflagradas graças às relações em redes sociais. A medicina, os transportes, as comunicações, as relações interpessoais, 0 tempo, estão nitidamente passando por novas interpretações por conta dos avanços tecnológicos. Então, como fazer um teatro que examine o hoje e que dialogue com esse tempo, sem passar pelo cruzamento entre teatro e tecnologia? Se tudo é modificado e alterado pelas mídias, como a própria ideia de percepção e recepção, como ignorar estas mídias na criação cênica atual?

O poder de escolha é do encenador: deixar de lado recursos que podem redirecionar nosso olhar quando adotados de forma criativa e crítica, sem ceder aos encantos da virtuose do uso ou utilizados pelo puro 'poder da máquina'? A aventura da criação artística cênica pode ser feita de várias formas. Avião supersônico ou mera carroça, o que importa é a potência poética, artística, crítica, de inteligência e de sensibilidade representada.

Creio que a forma, o meio (mídia) que usamos para nos transportar e fruir nessa aventura pode alterar consideravelmente a maneira como avaliamos os resultados dessa aventura. Cada vez mais acessíveis e próximas, potencializando discursos estéticos urgentes, as artes cênicas sofrem mudanças com o aparato das tecnologias promovendo novos níveis de participação e elaboração.

Seria extrema arrogância afirmar que produções cênicas que não utilizam certos recursos tecnológicos são melhores ou piores que outras. O cerne da questão não está na comparação entre espetáculos, mas na constatação de que a tecnologia está presente em todos eles, desde o começo dos tempos.

Porém, não deixo de lembrar que o uso da tecnologia pode ser desastroso, como no caso de armamentos ou acidentes complexos como o recente acidente na usina nuclear de Fukushima, no Japão, em que a tecnologia fora de controle passa a ser o algoz. Nas artes é a mesma regra. Quando a tecnologia é empregada de forma equivocada, sem reflexão, apenas na levada dos modismos, os resultados podem ser desastrosos. 
Assim, esta pesquisa também se interessa pela seara pedagógica do teatro, a aprendizagem de novas formas híbridas, afim de criar uma estrutura, uma cartografia de modalidades no uso das tecnologias de imagens em cena, novas visões e reflexões de alunos, pesquisadores, técnicos e criadores cênicos; com o intuito de abrir um leque de possibilidades referente ao uso do audiovisual na cena, seja a experimental das escolas, seja a experimental dos grandes palcos.

Num cenário de pouquíssimas publicações sobre o tema, acredito que esse estudo possa causar reflexão e criação. Acredito que existam muitas formas e princípios do uso do audiovisual nos dias de hoje, e mais ainda num futuro próximo. Mas nesta pesquisa conduzirei a análise de três formas 'espaço, tempo, corpo' que acredito serem as mais recorrentes e que estruturam matrizes de possibilidades cênicas.

Quero com isso provar que com a inclusão de novas tecnologias a cena modificase, o teor cênico altera-se e a cena torna-se mais ramificada, re-poetizada, justaposta, somada, fragmentada, exigindo uma nova percepção de leitura.

A questão cairá sobre lugares da criação (artista) e da percepção alterada (público), já que a utilização de cenas em tempo real criam uma reforma na cena, abrindo outras narrativas, relações com o atuante, possibilidades de iluminação, cenografia e dramaturgia.

Os capítulos seguem com os seguintes princípios:

- Capítulo 1 é intitulado 'A Imagem-Espaço: Os recursos da tecnologia da imagem na criação de novas espacialidades cênicas'. A partir de um breve panorama histórico, que visa recuperar os pioneiros no uso das tecnologias em cena, analisei como essa tecnologia subverte as questões espacias, criando novas brechas entre encenação e cenografia, reconstruindo espaços figurativos, poéticos, estranhados, justapostos e até abstratos. Analizei artistas que incorporaram as máquinas do cinema para a cena, como Meyerhold, Piscator e grupos atuais como La Fura dels Baus, Rimini Protokol e Gob Squad, dentre outros.

Com as possibilidades eletrônicas e digitais ampliando e entrando no dia a dia do mundo, percebemos uma diferença entre trabalhos multimídia e intermídia. Espetáculos multimídias, cada dia mais comuns, são espetáculos que utilizam mídias 
eletrônicas ou digitais como suporte técnico, ou seja, fazem apenas um uso técnico dessas mídias, semelhante ao uso da iluminação, sem efetivamente entrarem nas possibilidades de metalinguagem, sem refletirem sobre a mídia usada.

Os trabalhos com utilização mais ostensiva da tecnologia auto-reflexiva chamaremos de intermídia. Esses trabalhos estão em outro patamar de utilização tecnológica, pois os efeitos das imagens tecnológicas são mais verticalizados e autoreferentes.

Com os aparatos eletrônicos e digitais, e com a internet, os paradigmas de "presença" e "espaço" podem ser revistos, pois a virtualidade saiu dos romances de ficção cientifica do início do século para apossar-se das artes, em especial das artes cênicas, com o poder de embaralhar mundos e territórios com o uso de recursos da tecnologia, em especial das imagens tecnológicas.

O mesmo paradigma de espaço via imagens tecnológicas pode ser utilizado com recursos da abstração, como apontamento de espaços mais subjetivos. Muito usada em trabalhos de diálogo entre dança e tecnologia, a relação abstrata como efetivação de um espaço dado ou relacionado é cada vez maior, na dança, no teatro, no circo, na ópera e até em shows musicais, com o uso de telas de LED e muitas imagens gráficas que conversam com princípios das artes visuais e da vídeo arte.

- Capítulo 2, que chamo de 'A Imagem-Tempo: A imagem tecnológica na criação de efeitos de tempo e memória - passado e futuro'. As relações entre o tempo foram o foco, já que as questões temporais absorvem boa parte das narrativas. Com a inclusão de recursos digitais (incluindo a internet) podemos ampliar as noções de tempo e memória, e a utilização de elementos cinematográficos / videográficos pode criar, neste momento, atmosferas temporais cada vez mais elásticas.

- Capítulo 3, abordei 'A Imagem-Corpo: as tecnologias da imagem na construção de efeitos de presença do ator / performer'. Apliquei algumas relações possíveis entre as tecnologias da imagem e o corpo dos atuantes, sejam atores, dançarinos ou performes. Foi um diálogo visando ampliar as relações entre corpo e cena e também entre corpo e máquina.

Para tanto, os capítulos apresentaram uma estrutura de escrita e reflexão desenvolvida perante a análise de toda abrangência do problema, sempre iniciando com os princípios filosóficos e estéticos que orbitam cada tema, para em seguida 
analisar grupos e artistas que tiveram uma prática no passado e a forma de reverberação do seu trabalho na cena contemporânea. Exemplificando com produções mundiais e brasileiras desenvolvidas recentemente, incluindo a análise de realizações de minha autoria como diretor teatral e cenógrafo.

Importante dizer que abordei o uso de tecnologias da imagem numa 'cena contemporânea' que não limitei exclusivamente ao teatro, mas expandi para áreas da performance, da ópera, da dança e do circo, já que as fronteiras entre essas linguagens parecem a cada dia se tornarem mais movediças e borradas. Esse ciclo que liga as linguagens, mídias e cena, é um processo de transformação, criação, apropriação e contaminação.

Deve-se observar, contudo, que embora as tecnologias da imagem em cena ainda estejam em sua infância, seu ritmo rápido de desenvolvimento nos permite supor que aquilo que consideramos atualmente meramente potencial, um projeto futurológico, pode na verdade ser realizado mais cedo do que se imagina.

O barateamento de softwares e equipamentos, que exigirá um rápido domínio dessas formas e percepções, é extremamente positivo para que técnica e estética se desdobrem em renovações cada vez maiores. O tempo das primeiras experiências das vanguardas cinematográficas, e das segundas vanguardas já com a vídeo instalação, soma-se às novas formas de relação do atuante com seu duplo digital, com cenários virtuais e relação com o mundo via transmissões em tempo real.

Se tudo isso muda o cinema, que muda o vídeo e que muda a cena teatral, outra importante questão seria perguntar se muda, e o quê muda, nos meios de interpretação? Os artistas acompanham todas estas renovações? Isso altera nossas formas de ver um espetáculo cênico nos dias de hoje? Para além do cinema e vídeo, quais as contribuições dos games e da internet para as encenações que virão? Por que não reivindicar às artes interativas o nome Teatro? Se não, qual seria o nome dessa nova arte que agora se desenha?

Para refletirmos sobre o uso positivo dessa força nas artes, novos mecanismos de mediação são implementados para estreitar o espaço entre o virtual e real, entre a presença e o efeito de presença. Novas práticas são adotadas para atender as mesmas 
audiências fragmentadas num território novo, complexo, ramificado e interligado: o novo universo midiático que se abre para as artes cênicas.

Dessa maneira, o estudo que apresento será de grande valia para dramaturgos, encenadores e performes, que verão as possibilidades de espaço, tempo e corpo alteradas e expandidas, e para criadores cênicos, bem como artistas da área audiovisual e interessados em geral sobre os diálogos possíveis entre arte e tecnologia. 


\title{
Capítulo 1
}

\section{A Imagem-Espaço: Os recursos da tecnologia da imagem na criação de novas espacialidades cênicas}

\author{
A arte está sempre na vanguarda. Por meio da arte trabalhamos \\ com a sensibilidade e a relação criativa com o mundo. Aurora Ferreira
}

\begin{abstract}
A adição de imagens e da realidade confere a imagem e a realidade uma nova dimensão, uma espécie de quarta dimensão que enriquece incontestavelmente um espetáculo. Do meu ponto de vista, as artes servem exatamente a isso. Trata-se de criar uma nova dimensão nos espíritos dos expectadores.

Abel Gance

É apenas quando nós nos comparamos com o passado que construímos algo. Jean Luc Godard
\end{abstract}

Quais são as possibilidades que se abrem quando as artes cinematográficas e audiovisuais se encontram? E quais seriam as novas possibilidades de invencão de espaços quando se tem à mão tecnologias cada dia mais baratas e fáceis de manuseio? Se o mundo passa por uma nítida revolução tecnológica e o lugar das tecnologias nas artes é de amplo progresso, qual seria o lugar das tecnologias da imagem nas possibilidades de enfrentamento e reinvenção da cena do presente e real?

Inicio essa pesquisa refletindo sobre as relações entre espaço e as novas tecnologias da imagem. Aqui buscarei entender alguns processos de cruzamento entre a presença das imagens tecnológicas nas artes cênicas quando dialoga com questões espaciais. Muitas vezes, a palavra espaço pode ganhar um sentido territorializado, isto é, físico e simbólico, pois afinal, umas das características que definem a existência da arte é o fato de ela ocupar um espaço comumente pensado como espaço institucionalizado (museus, galerias, etc).

Desde a Grécia antiga a discussão sobre o espaço toma a atenção das artes cênicas, vide as relações múltiplas de planos no espaço cênico do teatro grego. A interrelação entre os planos Terrestre, Infernal (Hades) e Divino (superior) já mostra as relações poéticas e simbólicas do pensamento teatral em relação a transformação dos espaços.

Reflexões sobre o espaço ainda ocupam boa parte da criação artística, em especial a arquitetura cênica, a cenografia e, claro, a encenação, que são objeto de vários enfoques perceptivos e conceituais sobre espaço. Dois deles ancoram boa parte deste primeiro capítulo. 
O primeiro é a Fenomenologia, de Gaston Bachelard ${ }^{4}$, que concebe o espaço como 'fonte de devaneio poético do ser', e a Física, de Einstein ${ }^{5}$, que pensa o espaço e o tempo como entrelaçados, formando uma entidade única que ele chamou de 'continuum espaço-tempo'. Assim, espaço e tempo como condições de conhecimento são apropriados, mas espaço e tempo não permanecem como instâncias absolutas, são tanto referências de apropriação quanto de transformação em um processo criativo.

Logo, é para a flexibilidade da moldura que Bakhtin aponta quando afirma que o tempo e o espaço, ao mesmo tempo que prévios, pré-existentes, são redefinidos pela intervenção modificadora da arte. Mas de que maneira o espaço muda e interferem o projeto e processo artístico? Como estes espaços permitem iniciar processos de percepção diferenciados, devaneios, memórias?

Quando olhamos ao redor e percebemos o espaço que nos circunda, essa percepção pode acontecer em três planos: a atitude contemplativa do mundo circundante, no sentido utilizado na filosofia zen, o olhar analítico voltado para os detalhes, as diferenças e as semelhanças e, por último, o olhar lúdico e poético que transforma simbolicamente o que vê, refuncionalizando os objetos, subvertendo atmosferas e transpondo o espaço real o espaço da ficção. (COELHO, 1999, p.166)

As relações entre o "eu" e o espaço desdobram-se em novas elaborações, sejam elas ligadas às percepções do aqui e agora, como na filosofia do zen-budismo, ou sejam relacionadas a outras técnicas contemporâneas no Ocidente, como a Gestalt. O espaço é transformado em lugar quando adquire definição e significado.

Essas percepções apontam que a nossa representação mental do espaço, elaborada a partir de experiências (diretas ou indiretas), constrói uma imagem que supervaloriza alguns aspectos espaciais em detrimento de outros, estabelecendo um processo de "filtro" em que o observador, à luz de seus propósitos, seleciona, organiza e dá significado ao que vê.

Nas artes cênicas, a questão espacial toma cada vez mais um aspecto caleidoscópico, que se transforma em múltiplas possibilidades, sejam poéticas,

\footnotetext{
${ }^{4}$ Bachelard (1884-1966), filósofo e poeta francês que estudou sucessivamente as ciências e a filosofia; seu pensamento está focado em questões referentes à filosofia da ciência.

${ }^{5}$ Albert Einstein (1879-1955), físico teórico alemão radicado nos Estados Unidos é conhecido por desenvolver a teoria da relatividade, recebendo o Nobel de Física em 1921 pela correta explicação do efeito fotoelétrico; no entando, o prêmio só foi anunciado em 1922. O seu trabalho teórico possibilitou o desenvolvimento da energia atômica, apesar de não prever tal possibilidade.
} 
políticas ou estéticas ou todas essas e muito mais. Para Patrice Pavis ${ }^{6}$ as relações de significação, leitura e criação do espaço são as seguintes:

1. Espaço Dramático - espaço dramatúrgico do qual o texto fala, espaço abstrato e que o leitor ou o espectador deve construir pela imaginação (ficcionalizando).

2. Espaço Cênico - espaço real do palco onde evoluem os atores, quer eles se restrinjam ao espaço propriamente dito da área cênica, quer evoluam no meio do público.

3. Espaço Teatral - espaço ocupado pelo público.

4. Espaço Textual - espaço em sua materialidade gráfica, fônica ou retórica; espaço da "partitura" onde são consignadas réplicas e didascálias. O espaço textual é realizado quando o texto é usado ou não como espaço dramático ficcionalizado pelo leitor ou pelo ouvinte, mas como material bruto disposto ao olhar, audição e visão do público.

5. Espaço Lúdico (ou Gestual) - espaço criado pelo ator por sua presença e deslocamentos, por sua relação com o grupo e disposição no palco.

6. Espaço Interior - espaço cênico enquanto tentativa de representação de uma fantasia, de um sonho, de uma visão do dramaturgo ou de uma personagem.

Esses conceitos e percepções tornam-se ainda mais complexos quando somados às experiências mais radicais em performance e somados ainda ao uso de tecnologias que embaralham os sentidos de espaço em fruições poéticas quase inéditas, e que trazem em sua poética novas formas de perceber a questão do espaço, analisando e até duvidando de seus limites e possibilidades iniciais.

Quando esses "novos" espaços requisitam tecnologia? Entre a atuação ao vivo dos atores e os recursos multimídias, como criar um senso de presença no espaço virtual? A tecnologia tem potencialmente transformado e nos levado a novos espaços, qye tornam impossíveis recepções únicas.

A busca por espaços múltiplos, dinâmicos, parece ser características da dramaturgia contemporânea, que flerta com a rapidez do corte cinematográfico, exigindo assim dinamismo na apresentação de espaços virtuais, seja para meramente embelezar a cena ou utilizados de forma óbvia, como quando a projeção de imagens apenas reflete, exibe, mostra e nos dá exatamente o que o texto-diálogo pede.

\footnotetext{
${ }^{6}$ Patrice Pavis é professor na Universidade Paris VIII e autor do Dicionário de Teatro (Perspectiva). As relações de significação estão no livro 'A análise dos espetáculos'
} 
Considero que o uso da tecnologia da imagem de forma aleatória e rasa, embora frequente, não propícia saltos estéticos, tampouco possibilita novas interpretações. A seguir, reflito sobre o uso das tecnologias da imagem na busca da criação de novos espaços e mundos, para além do figurativo.

Lembro que, na seara da contemporaneidade, o cruzamento de linguagens (espaço real do ator, público e espaço virtual - tecnologia em projeção ou geração de imagens digitais) resulta sempre em material complexo e multifacetado, muitas vezes caótico, e alcança um terceiro espaço, que é o da recepção, em que o jogo da percepção poética abre campos e novas sinapses de presença e entendimento.

As artes sempre buscaram escapar da realidade e, ao mesmo tempo, apresentá-la, criando uma distância ou proximidade parodoxal com a vida, buscando e criando novos mundos, num jogo entre o espaço da representação dado e as possibilidades de imagens de outros espaços virtuais. Num jogo entre o real e o virtual, entre o presente e o imaginado, processos simbólicos e poéticos são cada vez mais comuns no campo da cenografia virtual.

Nas artes cênicas, questões como falso, duplo ou simulacro, parecem ser a espinha dorsal para uma reflexão acerca das próprias estruturas do jogo cênico ao falsear, fingir a realidade ou estilizá-la para que observemos com maior objetividade seus aspectos materiais ou abstratos. Seria previsível que justo nas artes cênicas houvesse um encantamento pelo uso dinâmico das tecnologias para cooperar com as recriações de novas possibilidades do fingir em cena.

Criar campos de fricção entre o real e o falso, entre o virtual e o real, sempre foi tarefas que se desenvolveu no âmago das artes cênicas e das artes em geral, onde encontramos as perguntas: qual é a natureza fundamental da realidade? Como ter certeza dela? Desde os primórdios estas perguntas pertencem à filosofia e também nas artes.

A Encyclopedia od Science Fiction traz no verbete 'percepção' a seguinte definição: 'maneiras pelas quais nos conscientizamos e recebemos informações do mundo exterior, principalmente por meio dos sentidos, são denominadas percepção'. Os filósofos divergem profundamente na questão de saber se a nossa percepção do mundo externo corresponde a uma realidade verdadeira ou se ela constitui simplesmente hipóteses, construções intelectuais, que podem proporcionar uma 
imagem incerta ou parcial da realidade externa. E, ainda, se a realidade externa é, de fato, ela mesma uma construção mental.

A percepção sempre foi e é tema primordial no campo artístico (literário ou cênico). O que sabemos efetivamente sobre o mundo em que aparentemente existimos? E como o conhecemos? O fato é que desde os hipocrates, nome dado pelos gregos antigos aos primeiros atores, até as relações entre o personagem ou a falta dele numa perspectiva do teatro performativo, ou mesmo da própria performance (subtração do personagem para apresentar o atuante, o performer), é nítido que as artes cênicas sempre brincaram com todas as espécies de possibilidades no território paradoxal dos simulacros: entre 'o que é e o que não é' entre o fingido e o verdadeiro, entre a imitação e o modelo e, agora, em tempos digitais, entre o real e o virtual.

A erosão do real e seu deslocamento por imagens simuladas, como no universo da obra pós-moderna 'Simulacro e simulação' de Baudrillard', é uma discussão sempre viva que parece fazer mais sentido do que nunca em tempos digitais. A operação de simulação nunca cessou: "fazer parecer real o que não é" foi invocado muitas vezes para dar conta tanto da escultura grega quanto da perspectiva do renascimento (a famosa ilusão de profundidade), da pintura dita trompe-l'oeil" até o apogeu do movimento barroco.

Cada época alimentou seus simulacros. A nossa tem como particular feito criar entidades híbridas, situadas entre o que é real (segundo o modo do objeto) e o que não é (segundo o modo da representação). Nosso mundo cotidiano começa a se povoar de estranhas criaturas, quimeras modernas, ícones de menus de computadores regulando a composição de textos virtuais (imagens não concebidas para mera visualização, mas para encadeameamento da ação), cujo deslocamento físico manipula objetos imateriais (texto/imagem).

Sem dúvida, estas composições indicam, entretanto de forma balbuciante, a emergência de realidades artificiais como forma de apresentação de um neoambiente, virtualizando objetos e espaços, gerando necessariamente novas

\footnotetext{
${ }^{7}$ Baudrillard (1929-2007), sociólogo e filósofo francês. Suas teorias contradizem o discurso da 'verdade abosluta' e contribui para o questionamento da situação de dominação imposta pelos complexos e contemporâneos sistemas de signos. Os impactos do desenvolvimento da tecnologia e sua abstração das representações dos discursos são outros fenômenos que servem de objeto para seus estudos do famoso livro 'Simulacros e simulação' de 1981.
} 
modalidades para definí-los e animá-los, constituindo um novo espaço de percepção onde o ver/falar/mover/sentir recompõem suas operações.

Numa situação em que a imagem não é somente representação, mas simplesmente presentificação, em que a imagem não é mais figurativa, mas também funcional, ela tem como lastro um coeficiente de realidade, reencontrando novos e cada vez mais dinâmicos caminhos, sua eficácia primeira. Imagem-objeto, objetoimagem, sem dúvida: termos genéricos que designam territórios e o uso de palavras compostas (como aplico nesta pesquisa para nomeação dos capítulos) indicam ainda nossa dependência do mundo da representação, referência bipolar ao antes/depois.

\footnotetext{
A imagem não é mais restrista à transformação do elemento representado em elementos representantes. Em suas possibilidades, ela é metamorfose, metáfora purificada do real, por vezes inconfortável e mutante, a ponto de ser uma representação pura que escapa aos confins do corpóreo. Este não é mais o limite. Aspira-se à representação imagética de processos mentais. $A$ imagem, agora, pode atingir o incorpóreo; ela legitima o real. (NEIVA, 1986, p.76)
}

O virtual no lugar do real corresponde a uma diferença visivelmente exportada das categorias da representação (imagem no lugar do objeto, máquinas no lugar do homem). A decodificação de sua trajetória, em termos de evicção ou de predominância do virtual sobre o real, é sem dúvida portadora de uma interrogação ética salutar.

Nesse sentido são muitos os jogos, as possibilidades de alternância entre o real e o virtual e suas combinações, que resultam em muitas possibilidades estéticas, como um caleidoscópio de possibilidades infinitas, em que a soma e o desdobramento de técnicas e tecnologias cada vez mais complexas, junto a formas de criação cênica mais híbridas, elevam a cena digital a um padrão de desenvolvimento rápido, complexo e mágico.

Em tempos em que as palavras clone e clonagem deixaram de pertencer ao conjunto das ficções mais distantes e passaram a ser da ordem do dia, seja na forma mais simplista de avatares tecnológicos em laboratórios ou na forma de nick-names dos sites de relacionamento social das redes da internet, temos a apresentação do real pelo virtual (seja em cabines de aprendizado de pilotagem, chats para sexo virtual), de forma que o virtual não substitui o real, propriamente falando, e uma das 
formas de percepção, num misto em que as duas entidades são simultaneamente requisitadas.

$\mathrm{Na}$ interpretação do real pelo virtual, imagens de estruturas científicas distantes demais (na astronomia) ou pequenas demais (microbiologia) são difíceis de clara leitura, alimentadas por modelos refeitos, modelos simulados como as fotos obtidas. É um acordo progressivamente obtido na interpretação julgada satisfatória, em que o virtual e real são duas faces da mesma questão. O virtual não substitui o real, ele ajuda a lhe dar sentido.

As possibilidades não se esgotam. Como recurso atual no cinema, o mundo real sofre uma transfusão para o mundo virtual e Ihe atribui anima com a tecnologia performance-capture, utilizada em produções do diretor neozelandês Peter Jackson e sua empresa de pesquisa em efeitos especiais, a Wetta, como acontece em 'O Senhor dos Aneis' e 'King e Kong'. Neles há a captura de movimentos e emoções humanas para transferí-los a objetos inanimados e personagens.

A quebra das barreiras entre virtual e real na sala de exibição do cinema do futuro acontece por meio de lentes polarizadas, novas tecnologias em 3-D, destilação de perfume, som cada vez mais puro (como o sistema THX, sistema de sonorização de salas de filmes e salas de cinema, criado pelo cineasta e produtor americano George Lucas), movimentos físicos da plateia, atores figurantes na sala de exibição e aumento da tela de projeção.

O paradoxismo é atingido quando esse crescimento é atrelado à eliminação das bordas: cinema 360 graus, ou, melhor ainda, um cinema hemisférico/esférico (como na Geode de Paris), renovando assim o processo do espaço caleidoscópio. Não havendo mais bordas, a imersão total daquele que olha será garantida.

Atualmente a NASA já pesquisa simuladores dinamizados que permitirão um salto histórico nas técnicas de representação. Como o teatro ou a performance reagirá a esses inventos? Como o trabalho da encenação, cenografia, dramaturgia e interpretação reagirá a isso?

Com isso, a cada dia, os conceitos de presença e efeito de presença parecem sofrer alterações cada vez mais potentes, ao mesmo tempo que reafirmam a capacidade do homem de reinventar os processos de observação e recriar outras narrativas mais imersivas. Possibilitando, dessa maneira, a revisão das ferramentas 
tecnológicas, hoje e amanhã, num processo interminável que propõe rapidíssimos e avançados saltos em possibilidades novas do fazer criativo.

Dos antigos ritos cênicos, com a presença da consciência alterada dos atuantes, ou das performances imersivas com efeitos visuais para serem sentidos apenas na retina do observador, os artistas da recriação do espaço-mundo (real) encontram vasto material no campo da tecnologia digital (virtual).

Nessa seara encontramos novas possibilidades de alternância, virtualidades, paralelismos e novos campos de atuação/percepção, seja na confluência do teatro/performance com recursos da tecnologia dos vídeo-games, no second life, em programas de inteligência artificial, hologramas ou técnicas cinematográficas de captação de movimentos, rascunhando um futuro próximo à presença do cyber-teatro ou da cyber-performance.

O termo cyber é emprestado da literatura de William Gibson $^{8}(1948)$ e seu romance Neuromancer, de 1984, e se refere a um universo que traspõe as barreiras das páginas da ficção e parece, cada vez mais, presenciar territórios das artes tecnológicas, e em especial nesta pesquisa, das artes cênicas na cultura digital.

Estamos no campo de batalha de uma revolução na forma de ver e interpretar as imagens. A questão da virtualização dos espaços, de caráter urgente, está relacionada a uma alteração radical na forma de conceber também o tempo, o ritmo e a estética.

Essa virtualização amplia nossa capacidade de ver e interpretar a vida na arte, e vice e versa, transformando os modos de criação cênica em diálogo com outras cenas somadas, justapostas, num jogo que se vai no duplo frontal do espelho: o infinito. Complexas, e cada vez mais ramificadas, nossas formas de ver e fazer teatral exigem com urgência novos paradigmas.

\footnotetext{
Ora, a virtualização constitui justamente a essência, ou a ponta fina, da mutação em curso. Enquanto tal, a virtualização não é nem boa, nem má, nem neutra. Ela se apresenta como o movimento meso do 'devir outro'- ou heterogênese- do humano. Antes de temê-la, condená-la ou lançar-se às cegas a ela, proponho que se faça o esforço de aprender, de pensar, de compreender em toda sua amplitude a virtualização. (LÉVY, 1996, p. 11)
}

\footnotetext{
${ }^{8}$ Gibson é escritor canadense que tem sido chamdo de 'profeta noir' do ciberpunk, subgênero da ficção científica, e cunhou o termo cyber espaço em seu conto 'burning chrone', posteriomente popularizou o conceito em sue romance de estreia, Neoromancer (1984). Prevendo o ciberespaço, Gibson criou uma iconografia para a era da informação antes da unipresença da internet e da década de 1990
} 
No diálogo entre o espaço real e virtual, sempre considerando as artes cênicas e a tecnologia de imagens, conduzimos nossa reflexão ao início do século XX com a aparição do cinema, e com a influência deste no teatro, transgredindo os limites da imagem na cena do espaço 'real' (teatro) e dinamizando as narrativas com truques e técnicas que estavam disponíveis somente até então no cinema; segmento que contava com visionários artistas que se lançaram a experimentar a contaminação do cinema com o teatro, recriando o lugar do atuante, novas possibilidades cenográficas, de encenação e outros dispositivos que dinamizariam a cena.

No resgate histórico a seguir, recupero os pioneiros artistas que buscaram criar novas condições no terreno do teatro somado ao cinema e depois ao vídeo: visando possibilitar o surgimento de espaços digitais.

\subsection{Os primeiros visionários}

Ao contrário de tentar destruir o teatro, o domínio ou a inserção de novas técnicas torna seus limites mais abrangentes, explorando seus territórios com novas fronteiras. Era o que provavelmente pensavam Edward Gordon ${ }^{9}$ Craig e Adolf Appia ${ }^{10}$, pioneiros em pensar o movimento em cena, antecipando o uso das novas tecnologias no palco. Acredito que repensar a trajetória desses dois artistas no passado é pensar a cena hoje.

Gordon Craig foi um homem de teatro completo: teórico, cenógrafo, ator, diretor. Seus textos originais trazem muitos desenhos de cena e cenários com papel transparente com muitas informações sobre pontos específicos do desenho, podendo servir como um hipertexto imagético e textual, já antecipando as possibilidades da imagem e texto dos modernos e interativos tablets de hoje.

Craig propunha, em meados de 1900, novas maneiras de perceber o texto teatral e o espaço-imagem, definindo o teatro como a arte do movimento, propondo a

\footnotetext{
${ }^{9}$ Gordon, ator, encenador e cenógrafo inglês. Foi uma das figuras mais interessantes e decisivas para a história do teatro ocidental do século XX. Foi um dos pilares do chamado simbolismo teatral.

${ }^{10}$ Appia (1862-1928), arquiteto e encenador suíço, cujas teorias, especialmente no campo interpretativo da luz, ajudaram a concretizar as encenações simbolistas do século XX. Era contrário a estética realista, por isso quis se utilizar dos elementos expressivos e simbólicos do teatro, da música e da luz. Foi o primeiro a usar a sombras no palco de forma deliberada, influenciando assim, as modernas concepções de iluminação teatral.
} 
criação de painéis móveis e redefinindo o espaço sempre em diálogo com a luz cênica. Para o profissional, esses painéis, que deveriam ser rápidos em entradas e saídas, já indicavam as possibilidades de mudança imagética pela troca de telas, antecipando a edição vertiginosa do cinema de alguns anos depois.

Em Les mille Scenes en une radicaliza as possibilidades do uso e sobreposições desses telões, liberando a cena da imobilidade: é inegável que a rapidez proporciona uma nova dinâmica na cena. Craig sonhou com projeções de luz, em cores, mas a projeção de imagem não estava prevista no seu horizonte estético. Com a afirmação 'Temos que refletir sobre e de onde viemos para refletir para onde se vai', Craig passa a ser um dos visionários do legado do movimento, ou seja, do uso do movimento em cena, recriando o palco frontal e dando-Ihe novo espírito.

Tão importante quanto Craig para a dinamização da cena, temos o suíço Adolf Appia, que estudou as relações de luz e forma no palco. Ele chama seu teatro de "A Catedral do Futuro" ou a "Catedral do por Vir", mudando a forma de pensar o movimento, iluminando e dando à luz um status nunca antes visto: prevendo o uso de projeção sobre a cena. A projeção para Appia daria um papel ativo à cena e em muitos casos suplantaria o papel dos personagens.

O francês Antonin Artaud ${ }^{11}$ (1896-1948) sonhava reformular o fazer teatral como uma nova maneira de utilizar o espaço; pensava o uso dinâmico de luz e de imagens colocando-se contra o teatro de texto francês. Defende em sua prática o uso de sons, imagens e efeitos, observar a força da música e prevê o uso de tecnologias em cena.

Porém, Artaud imagina o uso de projeções de forma completamente diferente de Meyerhold que, por sua vez, foi pioneiro no novo métier teatral, chamado por Louis Jouvet ${ }^{12}$ (1887-1951) de "criador de formas, um poeta da cena, que escreve com gestos, ritmos, com toda a língua teatral", afirmando ainda que "Meyerhold tinha de seu futuro espetáculo uma visão cênica tão viva que ia até a alucinação".

\footnotetext{
${ }^{11}$ Artaud foi poeta, ator, escritor, dramaturgo, roterista e diretor de teatro francês de aspirações anarquistas. Ligado fortemente ao surrealismo, foi expluso do movimento por ser contrário a filiação ao partido comunista. Sua obra 'o teatro e seu duplo' é um dos principais escritos sobre arte do teatro no século XX, referência para grandes diretores como Peter Brook, Jerzy Grotowski e Eugênio Barba 12 Jouvet, ator e diretor teatral francês nascido em Crozon.
} 
Seria aquele que não temeria as imagens que se introduzem no palco, pois ele teria a consciência que a nova arte do século $X X$, o cinema, se desenvolve com, e ao mesmo tempo, que o teatro de vanguarda. O seu teatro flertará com formas bastantes significativas e importantes no campo da tecnologia, propondo uma real e imediata incorporação dessas à sua cena.

\title{
1.2 Meyerhold e a cineficação interna e externa
}

\begin{abstract}
Os artistas do construtivismo se puseram a explorar as qualidades artísticas inerentes aos materiais, tais como a forma e a cor, e incorporar o espírito da era tecnológica moderna. Uma crença apaixonada de que o moderno artista-engenheiro poderia exercer um papel integral em moldar aquela sociedade. (DEMPSEY, 2002, p.106)
\end{abstract}

Como nos cenários construtivistas de 'O magnífico cornudo', dirigido em 1922 por Meyerhold ${ }^{13}$, máquinas e estruturas eram revistas aos olhos sensíveis, e assumidamente transformadas em formas aparentes e mostradas.

Alexander Rodchenko ${ }^{14}$ (1891-1956) e outros artistas do construtivismo, com destaque para Dziga Vertov, também se interessaram pelo desenvolvimento das tecnologias da imagem e do som, e desenvolveram o "Manifesto do Cinema Olho", ou seja, uma reflexão sobre o olho humano transformado pela câmera.

Rodchenko procurava incorporar na fotografia o movimento humano por meio da montagem, ou seja, a introdução do movimento na imagem estática. E Meyerhold desenvolveu seu sistema de treinamento biomecânico (o termo é, por si só, sugestivo quanto ao impulso futurista cibórgico).

Seu sistema biomecânico foi diretamente influenciado pelos estudos de tempo/movimento de Frederick Winslow Taylor (1857-1915), que foram transformando os enfoques soviéticos para a produção industrial. Taylor foi pioneiro no 'gerenciamento científico' e estudou o movimento dos trabalhadores da linha de produção para avançar ideias de economia de movimento e um sistema de ciclos de

\footnotetext{
${ }^{13}$ Meyerhold (1874-1940), grande ator do teatro e um dos mais improtantes diretores e teóricos do teator russoda primeira metade do século XX. Fez parte do Teatro de Arte de Moscou. Executado sumariamente pela ditaduta stalinista, sob acusação de trotskismo e formalismo. Seus trabalhos artísticos e escritos estiveram banidos até 1955 quando foi reabilitado pela corte suprema da antiga da antiga URSS.

${ }^{14}$ Alexander foi um artista plástico, escultor, fotógrafo e designer gráfico russo, um dos fundadores do construtivismo russo e design moderno russo.
} 
trabalho, a fim de maximizar a produção.

Meyerhold espelhou o sistema em seu treinamento de performance física, abraçando a ideologia e a estética da nova era mecanizada, e rejeitando os enfoques não científicos e anacrônicos de Stanislavski e Tairov. O documento de Meyerhold, The Actor of the Future and Biomechanics (1922), argumenta que a arte do ator tem sido concebida sempre de acordo com o contexto social e, que no futuro, o ator 'deve ir ainda mais longe ao relacionar sua técnica com a situação industrial'.

Para Meyerhold só o teatro cineficado suportaria ser comparado ao cinema e se apropriaria do estilo cinematográfico sem propriamente usar de projeção, câmeras e filmes. Sem a necessidade de projeção em si, mas modificando a estrutura do fazer teatral. É um pensamento sobre cinema que afetará diretamente o teatro: por exemplo, como gerar o close up em cena?

Enquanto a cineficação externa usava a projeção direta em cena, as imagens invadem e que gerava um desafio de aplicar as técnicas do cinema para a cena como:

- Multiplicidade de pontos de vista,

- Close up,

- Cortes,

- Movimento de cena.

A cineficação interna que Meyerhold procurava, buscava imitar o cinema utilizando os mesmos recursos, como o close-up, corte, foco, panorâmicas, por meio de treinamento corporal e de marcação sofisticada dos atores em cena. Na montagem de "Inspetor Geral", dirigida por Meyerhold, em 1926, ele adota o close up para o teatro com marcações bem definidas: gestual bizarro, gestualidade biomecânica para conduzir o olho e atenção, gestual realizado duas vezes para fixação, direcionamento de luz sobre o detalhe focalizado e todos os atores param e olham o gesto detalhado.

Esse processo de repensar as técnicas cinematográficas vai mudar o teatro, revolucionando recursos teatrais para alcançar um efeito mais cinematográfico. O que está em jogo é o efeito do cinema almejado em cena. Em Le bal masqué, dirigido por Meyerhold em 1917 (Fig.1) não vemos a tecnologia em cena, mas sim a busca pelo efeito cinematográfico.

No palco, o subir e descer de cortinas secundárias tem o objetivo de guiar o olhar do espectador fechando e abrindo a cena. Segundo Meyerhold 'devemos 
condensar no teatro todas as melhorias técnicas da época autenticamente teatrais'.

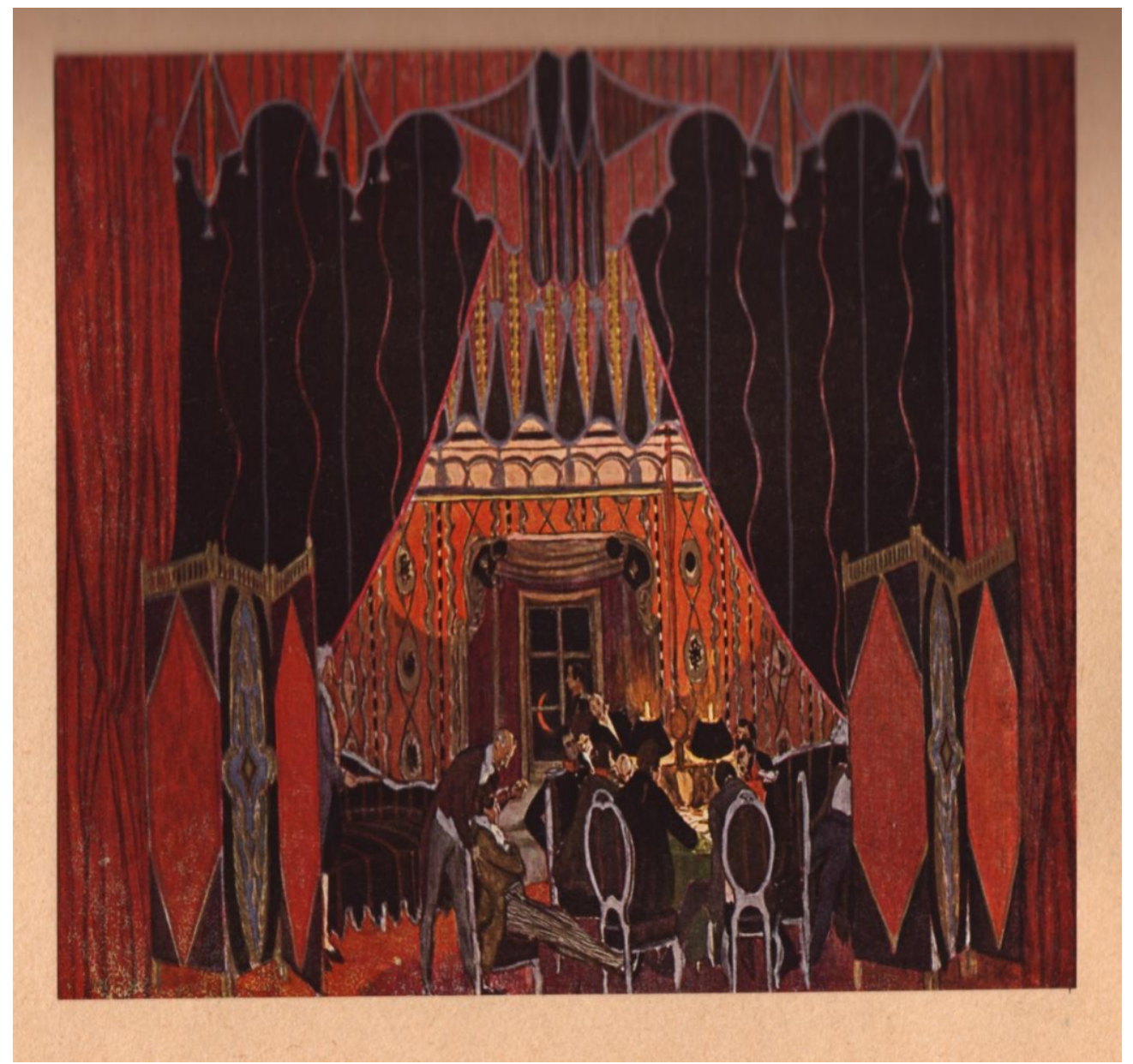

Fig.1. Ilustração de Le Bal masqué dirigido por V. Meyerhold, de 1917

O diretor também trabalha com o uso da cineficação externa, utilizando projeções em cena, reinventado elementos tradicionais do teatro reinterpretados como lentes cinematográficas, que mudam o olhar do espectador de forma rápida e dinâmica.

Em outro espetáculo de sua autoria, em 1923, La Terre Cabré (Fig.2), foram utilizadas na cenografia três telas num palco sem coxias, e nelas projetados os títulos dos capítulos e comentários sobre a ação da cena, como na perspectiva e tradição do cinema mudo da época.

Em La Forêt (Fig.3), de 1924, ele utilizou de forma mais radical a linguagem cinematográfica e introduziu um grande passarela sobre o palco com projeções de títulos e imagens na própria passarela. Na mesma peça, existe uma cena muda que faz referência direta ao cinema. 


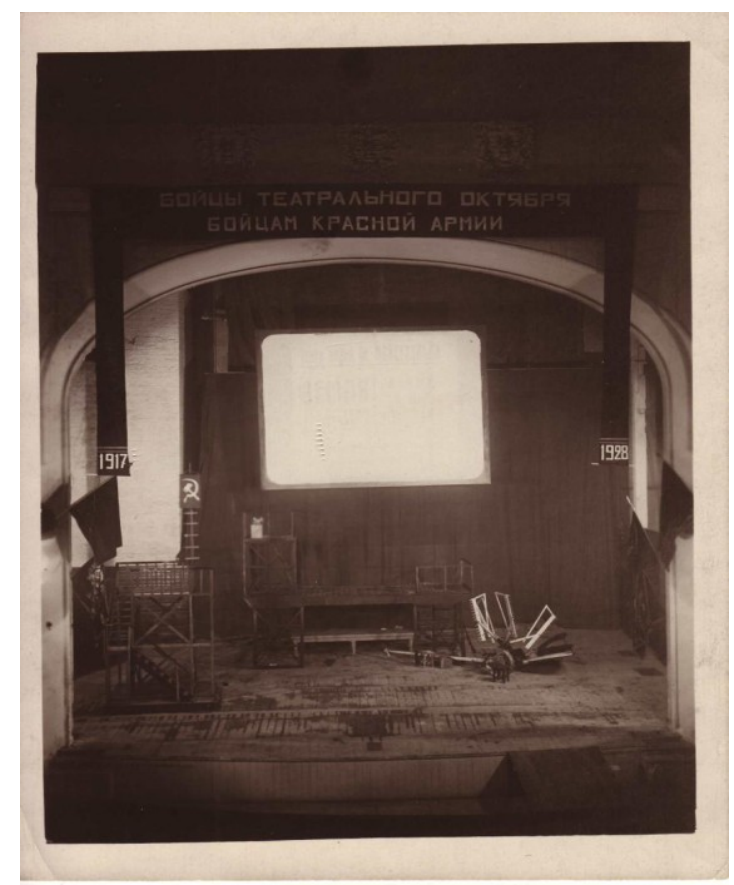

Fig.2. Maquete de La Terre cabrée, de Meyerhold, em1923

Esse espetáculo rendeu a Meyerhold muitos elogios da crítica, que apontava o trabalho como o filme que ainda não se tinha, em referência ao momento em que o cinema soviético estava adormecido por conta da política Stalinista.

As questões levantadas nessa época são, basicamente, as mesmas questões dos diretores de hoje, 2011, mas as respostas de hoje são diferentes graças ao amplo desenvolvimento da tecnologia.

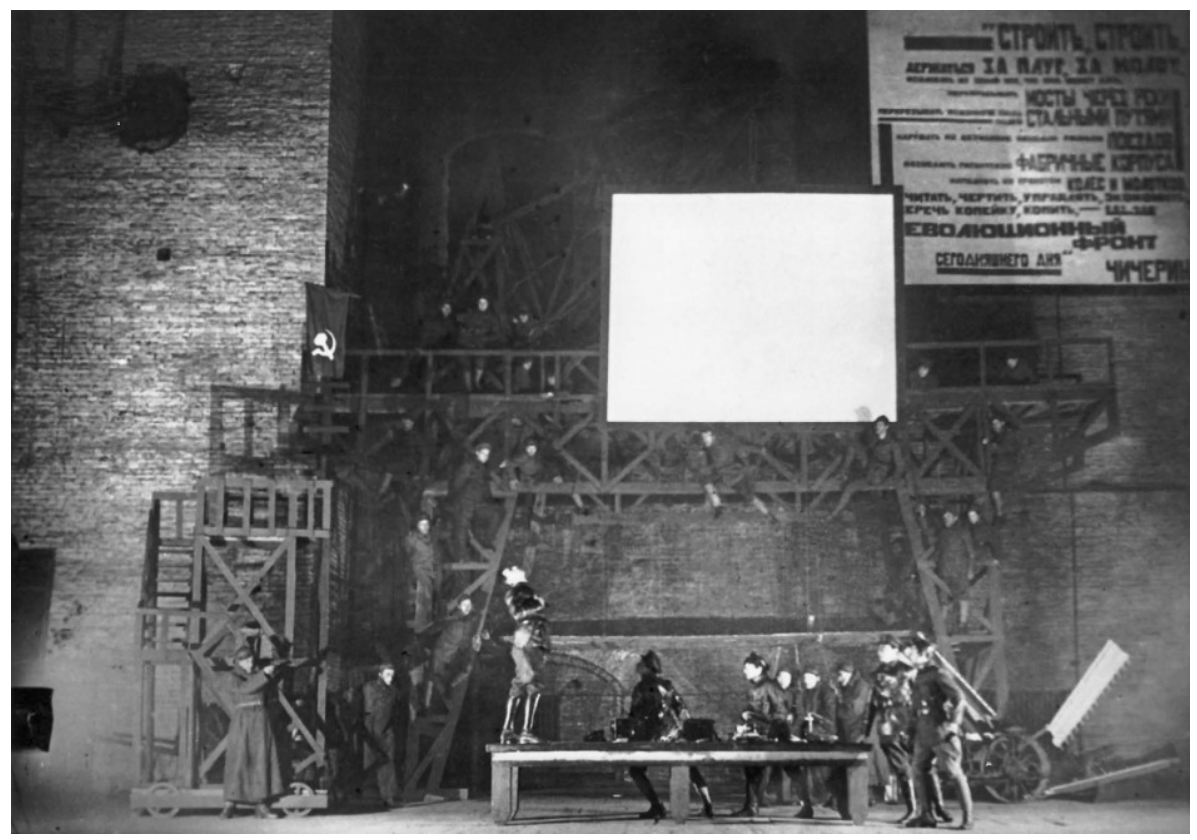

Fig.3. Representação da montagem La Forêt, de 1924 
Atualmente, o teatro também busca a cineficação, mas de forma externa, ou seja, com o uso de tecnologias do audiovisual apoiando a cena (recursos técnicos) ou dentro da própria cena (recursos estéticos), alterando dois espaços: o do palco, com a presença de janelas de imagem em cena, e o do espaço imaginado ou solicitado pelo texto/encenação.

\begin{abstract}
O uso da projeção CGI de larga escala, frequentemente animados de um jeito para imitar o efeito de um movimento horizontal de uma câmera de vídeo ou de crane shot (movimento da câmera quando faz um percurso vindo de cima para baixo, normalmente afastando-se, como se estivesse presa num boom) o que permite transições rápidas entre as cenas. A modelagem 3D e a animação, adicionados à alta resolução de projeção de vídeo que estão agora disponíveis, criam um efeito ilusório mais forte dos que as tecnologias antigas. Também empregando um revolve stage (plataforma mecânica no palco que serve para girar o cenário), os movimentos muito fluídos entre as cenas alcançam um efeito dinâmico como os cinematográficos. Além de tudo isso, o show é baseado numa linha narrativa direta, e o propósito primário dessa abordagem fauxcinematográfica é levá-lo a um estilo espetacular e de alto nível. (GIESEKAM, 2007, p.11)
\end{abstract}

Os apelos de Meyerhold para cinematificar o teatro e suas idéias sobre a mecanização estética do atuador ecoaram junto a outros importantes artistas russos, como Serguei Eisenstein. Porém não dirigiu muitos trabalhos com farto uso de projeções, como gostaria, pois os recursos disponíveis na época eram escassos para pagar a tecnologia cinematográfica de alto custo. Em seus planos chegou a pensar espaços cênicos com projeções no chão, nas paredes e no teto. Foi o início do pensar sobre um teatro imersivo, mais radical, como veremos mais adiante.

Meyerhold pioneiramente empregou cinegrafistas, incluindo Eisenstein (18981979) e Yutkevich (1904-1985), para desenhar cenografias de produções. Seus experimentos, na tentativa de uma "cineficação" do teatro, incluiram a projeção e a dispersão da luz via discos giratórios para o The Kidnapping of the Children (1922) e Be Kind to Horses (1922), onde Yutkevich projetou um ambiente totalmente móvel com degraus móveis e roda de moinho, trampolins, placas luminosas piscando com posters de cinema, decoração rotativa e luzes voadoras.

Eisenstein emprega o uso do filme no teatro em Le Sage, onde utiliza a projeção de um pequeno filme de quatro minutos no início da peça para mostrar que as imagens seriam o conteúdo de um diário, que seria roubado no enredo do 
espetáculo. O diário era representado por uma bobina de filme.

Nos anos 20, Sergei Eisenstein, que tinha trabalhado como cenógrafo tanto com Foregger quanto com Meyerhold, revolucionou a arte do cinema por meio de suas teorias de construção e edição de fotos, que chamou de 'montagem de atrações', justapondo imagens para fins politicamente dialéticos.

\footnotetext{
Os ritmos de percussão e a aceleração do tempo musical de sua técnica de edição de montagem intensificaram o impacto sensorial e dramático de seus filmes, enquanto as justaposições dialéticas de fotos operavam simultaneamente sobre a compreensão intelectual da platéia e sua interpretação dos fundamentos ideológicos dos filmes. (DIXON, 2007, p.73)
}

A montagem de Eisenstein provocava choques, tanto na recepção sensorial como na intelectual, numa práxis que comparava com as rápidas e acumulativas explosões que ativam um motor de combustão interna. Sua filosofia artística era semelhante à de Meyerhold, ao relacionar arte ao labor industrial, e justamente como Meyerhold tinha oferecido uma 'taylorização' do teatro, Eisenstein anunciou uma 'taylorização' do cinema.

A adoção de sistemas formais, geométricos e científicos do Construtivismo como parte do processo artístico se conecta intimamente ao modo como os sistemas formais de lógica matemática do computador são criativamente empregados no teatro tecnológico e digital dos dias atuais.

Noto que muitos artistas envolvidos com a programação de computador podem, inconscientemente, conceber seus trabalhos adotando um sistema ou fazendo uso do termo, mas inevitavelmente estão usando, na prática, um sistema rigorosamente científico e formal.

\subsection{0 espaço-imagem no expressionismo}

Nas considerações sobre os movimentos de vanguarda do início do século XX, a linhagem do expressionismo para a criação da cena com recursos tecnológicos de imagem é a menos distinta e primeiramente se relaciona ao uso da distorção e do exagero nas formas visuais, desde o rosto e o corpo humano até as vistas cênicas e os mundos virtuais.

Brecht descartou o expressionismo como um fenômeno puramente 
inflacionário. Desenhos de cenários expressionistas particularmente ampliam e enfatizam o macabro e o medonho, usando elementos de desenho como representações visuais simbólicas do psicológico e do alucinatório.

O desenho do teatro expressionista estava intimamente relacionado com a mídia baseada nas lentes, espelhando os efeitos cinematográficos de grande-angular e lentes de distorção. Muitas vezes eram realizados por efeitos de sombra e iluminação, tão desenvolvidos durante o teatro expressionista, que ainda hoje são usados e desdobrados em efeitos de projeção de imagens em cena.

O uso exagerado de linhas no expressionismo (seja na maquiagem, na cenografia ou na utilização de objetos) e o estilo estático de atuação colococaram o ator como uma parte integrante desse grande e obscuro design conceitual.

Estilos expressionistas e técnicas particulares de exagero foram adotados por inúmeros artistas e companhias em obras expressionistas, a partir dos anos 20 até os dias atuais, desenvolvendo produções que iremos referir ao teatro performativo. Como notamos no espetáculo M.T.M., do grupo catalão La Fura dels Bauls, em que projeções nos corpos dos atuantes em cena, ao vivo, eram realizadas e distorcidas por VJs que manipulavam imagens, ao vivo e pré gravadas, construindo dinâmicos e duplos espaços, com possibilidades de fragmentação da forma dos corpos e distorção física.

Muitos artistas do teatro performativo e da performance têm usado as contribuições e potencialidades do desenho lúdico e alucinatório das novas tecnologias para explorar o impulso primário do teatro expressionista. Embora a referência ao trabalho do La Fura dels Baus não seja de efeitos expressionistas, esses trabalhos com imagem videográfica se alimentam predominantemente dos conceitos deixados pelo expressionismo e por seu teatro.

\subsection{A experimentação na Bauhaus}

A Staatliches Bauhau, casa estatal de construção conhecida simplesmente por Bauhaus, foi uma escola de design, artes plásticas e arquitetura de vanguarda que funcionou entre 1919 e 1933 na Alemanha, configurando-se como uma das maiores e mais importantes expressões do que é chamado Modernismo no design e na arquitetura, sendo uma das primeiras escolas do gênero no mundo.

Em 1921, iniciam-se os primeiros experimentos teatrais da escola. Com a 
primeira exibição intitulada 'Arte e tecnologia - Uma nova unidade' (1923), os artistas foram influentes ao questionar noções de espaço e de espaço/tempo para aprimorar e reconfigurar formas artísticas e dramáticas.

No setor teatral muitos apoiavam a mecanização representada pelo americanismo. Oskar Schlemmer (1888-1943) dirigiu, não oficialmente, o atelier teatral e, durante o carnaval de 1922, apresentou 'Gabinete Figural', uma paródia sobre o avanço desenvolvimentista e as crenças tecnológicas, adotando em cena figuras planas e coloridas, em forma de disco, que se moviam numa faixa rolante executando movimentos grotescos.

Em 1926, desenvolvido por Schlemmer, a Bauhaus estreia o Ballett Triádico (Fig.4) no Teatro Metroplotina de Berlim, que não era uma peça de ballet no sentido convencional, mas uma combinação de dança, vestuário, pantomina e música. Na realidade, era uma peça anti-dança, uma forma de construtivismo dançante, que só poderia ter sido criada por um pintor escultor.

Mais tarde, os estudantes produziram a peça 'Teatro de Variedades Mecânico' e o 'Ballet Mecânico', estreado na Semana Bauhaus, cujo objetivo era ilustrar diretamente o zeitgeist (espírito do tempo), uma tentativa de dar ao espírito técnico da nossa era novas formas de expressão por meio de combinações não convencionais. Os fundamentos da máquina foram apresentados e transferidos para a forma da dança e um ritmo uniforme e constante foi selecionado, sem mudanças de tempo, a fim de sublinhar a monotonia do mecânico.

Em 1924, surge o trabalho "O Homem no Painel de Controle", que confrontava a relação entre o homem e a máquina onde a criação (a máquina) conquista o seu criador. O novo homem torna uma marionete controlada por uma força superior, não humana e indomável, tema muito revisitado pela ficção científica do cinema e da literatura dos anos 60 até final dos 90.

Mas foi outro artista da Bauhaus que se destacou pela tentativa de criar um novo espaço cênico. Walter Gropius, com base nos paradigmas da escola, entre eles pensar o contemporâneo em todas as artes, desenha e vislumbra espaços cênicos esféricos com giros e telas por toda a platéia, numa tentativa de (re)educar o olhar do espectador para o mundo, um novo mundo, e com isso transformar o espectador, formando por meio do novo teatro um novo olhar para um novo homem. 


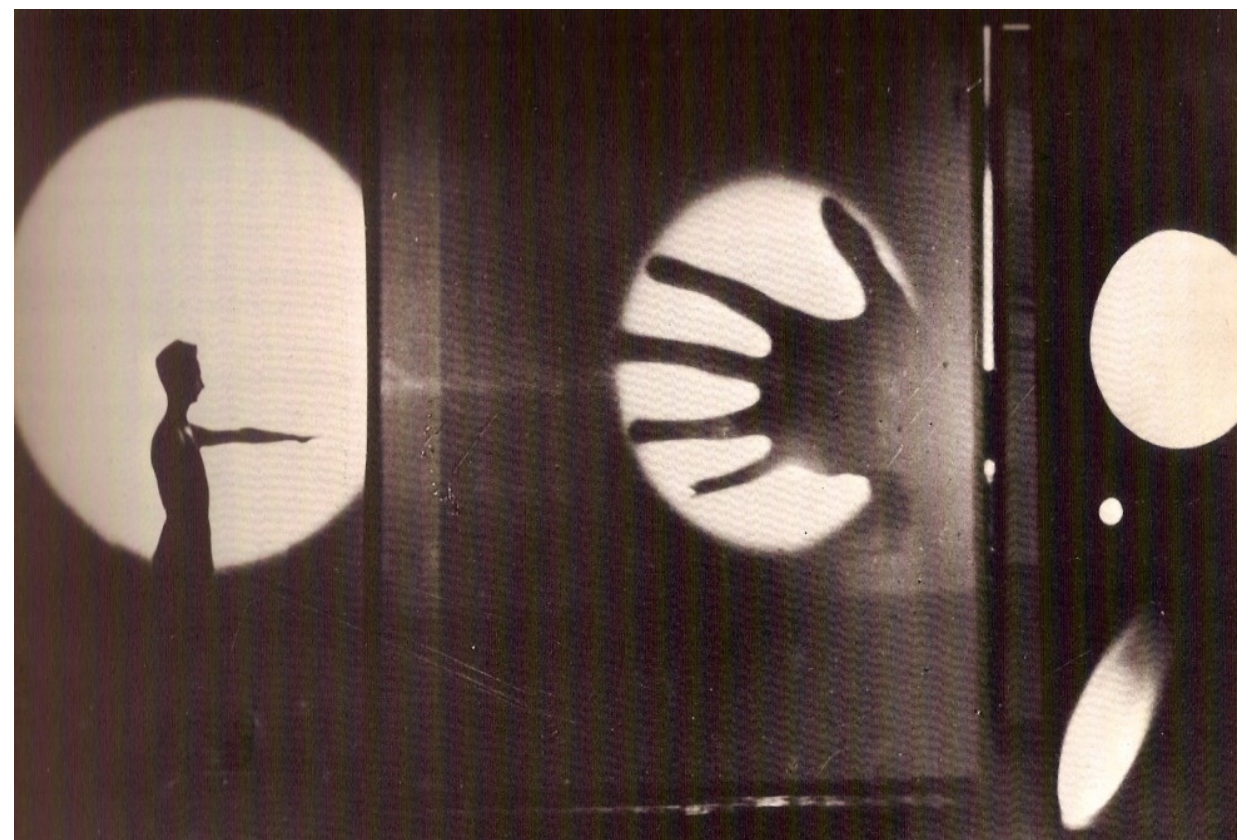

Fig.4 Espetáculo experimental da Bauhaus, dirigido por Schlemmer, em 1926, com efeitos de iluminação e projeção em jogos de sombras

O 'Teatro Total' (Fig.5), de Gropius, de 1926, prevê várias configurações entre cinema e sala teatral com muitos pontos a fixação de telas para projeção de imagem criando assim uma grande máquina teatral. Tudo que serviria como aparato teatral pode e deve ser visto, exibindo a tecnologia no espaço presente como parte do espetáculo. Mesmo bastante utópicos, esses projetos não realizados seriam influenciadores e bastante revisitados em projetos futuros.

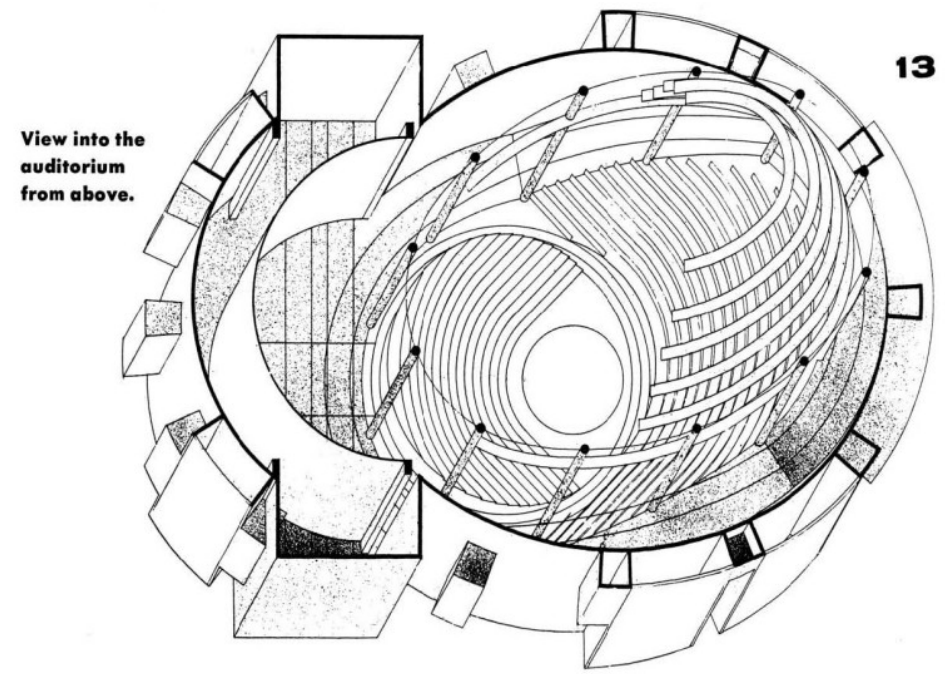

Fig.5 Ilustração de projeto de Gropius como 'Teatro Total', de 1926 
Durante a década de 1920, a partir de experiências com os preceitos sobre luz de Adolph Appia (1862-1928), a noção do Ubermarionette (Supermarionete) de Edward Gordon Craig (1872-1966) e seus próprios conceitos de espaço, linha e plano, Schlemmer elevou a narrativa espacial e a abstração coreográfica a novos patamares.

Ele esboçou trajes robóticos para a dança futurista, utilizou dispositivos mecânicos para movimentar figuras metálicas sobre fios de forma mais veloz e incluiu cabeça e mãos de uma performer em esferas de prata, como numa ficção científica, para a peça Metal Dance, realizada dentro de um cenário com superfície revestida de folhas de flandres corrugadas.

Schlemmer também preconcebeu, em seus projetos, figuras de avatares e de robôs artificialmente inteligentes para criação de uma figura artificial (Kunstfigur) sem fios. Esta figura poderia ser acionada por meio de controle remoto ou até mesmo auto propulsionada, quase livre da intervenção humana, permitindo qualquer tipo de movimento e qualquer tipo de posição durante o tempo que fosse necessário.

Além disso, as experiências de teatro na Bauhaus e o reprocesso da forma não partiam só das formas elementares das cores primárias investigadas pelos artistas, professores e alunos, e sim do modo de trabalho da máquina. Georg Muche ${ }^{15}$, pintor e professor, defendia que 'o elemento artístico da forma é um corpo estranho no produto industrial, o requisito técnico torna a arte um inútil extra'.

Em seu Stäbentanz (The Pole Dance, 1927), Manda von Kreibig dançou segurando duas varas de dois metros de comprimento, com outras oito presas à roupa, enfatizando uma coreografia geométrica em que o corpo humano era literalmente reduzido à condição de simples carregador/condutor da linha. A reorientação radical de Schlemmer quanto à topografia do corpo no espaço e sua redução a planos bidimensionais equivale e se harmoniza com a reconfiguração do corpo dançante dentro de ambientes digitais e no ciberespaço.

Em 2000, o estudo de M. L. Palumbo, da New Wombs: Electronic Bodies in Architectural Disorders (Novos Ventres: Corpos Eletrônicos em Desordens

\footnotetext{
${ }^{15}$ Georg Muche, arquiteto, pintor expressionista alemão (Bauhaus). Começou sua carreria artística com composições abstratas passando no final dos anos 20 para uma pintura lírica - decorativa com formas vegetais orgânicas. A partir de 1945 dedicou-se principalmente a temas figurativos.
} 
Arquiteturais), relaciona o trabalho de Schlemmer aos paradigmas do corpo virtual, descrevendo Schlemmer como um performativo,

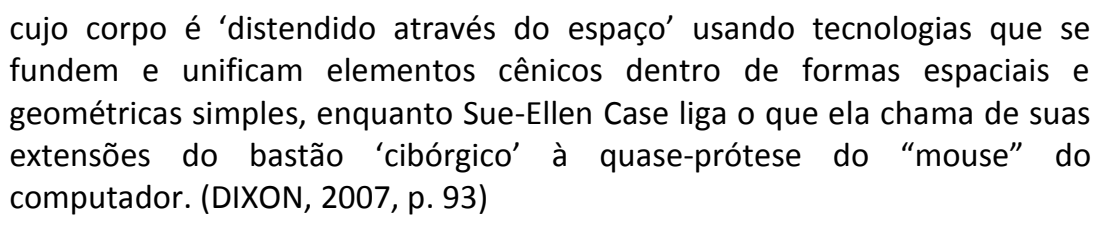

A visão otimista do progresso social e artístico promovido pelo movimento Bauhaus oferece um modelo para um equivalente contemporâneo da unificação da arte e da tecnologia moderna.

\subsection{Erwin-Piscator e O Teatro-Filme}

A década de 20 é marcada pelo espírito do pós-guerra e a diversidade das produções cinematográficas é reflexo deste sentimento. Nos EUA, os talentos de Charlie Chaplin, Buster Keaton e Harold Lloyd dominam na comédia; Cecil B. De Mille continua a realizar melodramas carregados de sensualidade e os primeiros filmes de gangsters e documentários fazem a sua aparição.

Na Europa, as experiências vanguardistas de Man Ray e Luis Bunuel marcam a França do pós-guerra. A Alemanha vive, na primeira metade da década, a era de ouro do expressionismo. Após anos de filmes de propaganda, o cinema soviético controlado pelo estado torna-se um centro criativo, cujo expoente máximo são as obras de Sergei Eisentein. O final da década viria a ser marcada por um dos mais importantes acontecimentos da história do cinema: a exibição do primeiro filme sonoro.

Embora todas as experiências de Thomas Edison, foi a pequena empresa Vitaphone, criada pela Warner Bros e pela Wester Electric, que desenvolveu em 1926, um sistema eficaz e produziu as primeiras curtas-metragens sonoras. Um ano mais tarde estreia a primeira longa-metragem sonora, The Jazz Singer, realizada por Alan Crosland e interpretada por Al Jolson. Os filmes sonoros foram um sucesso imediato e por volta do final da década cerca de metade das salas de cinema americanas estava preparada para exibir filmes sonoros. 


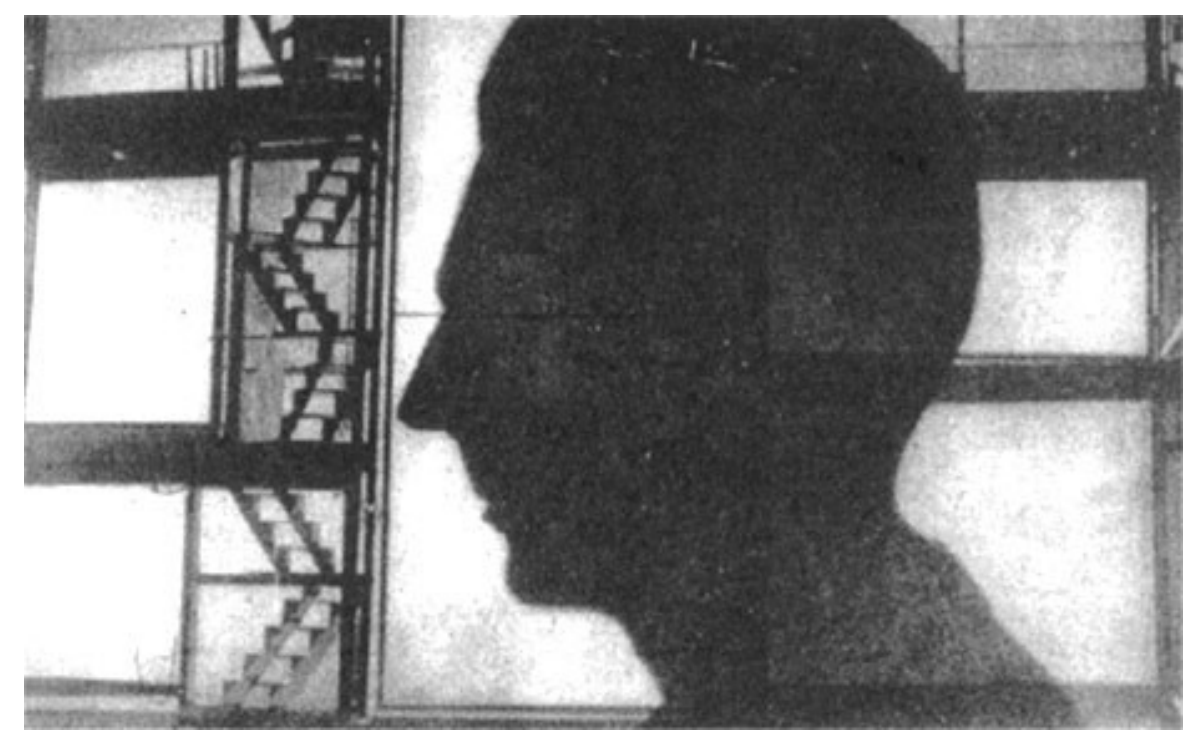

Fig.6. Projeção do perfil do próprio Piscator em cena de Hop là, nous vivons, direção própria em 1927

Na década de 20, cenas de documentários eram também empregadas com efeitos marcantes, quando Erwin Piscator (1893-1966) trouxe um filme noticiário editado para dentro do espaço do teatro para enfatizar a política dialética da produção de seu planejado documentário (Fig.6). De acordo com Hugh Rorrison, Piscator projetou pela primeira vez na história do teatro

uma mediação dialética de material factual, por exemplo, contra argumentando intentos políticos (discursos patrióticos nos debates dos Créditos de Guerra) contra suas consequências militares (sequência de filme com atrocidades do massacre na frente de batalha do Oeste). (DIXON, 2007, p. 101)

Em 1927, Piscator observou de que forma sua combinação de teatro e cinema transformou a moldura dramática, de modo que uma obra didática (Lehrstück) poderia ser desenvolvida a partir do que, superficialmente, pareceria uma obra-espetáculo (Schaustück). No mesmo ano Piscator criou uma produção de teatro multimídia definitiva. Seu teatro-filme era o tratamento do 'Dramas de estações' expressionista de Ernst Toller com o Hoppla, Wir Leben! (Hurrah, We're Living!) (Fig.7). 


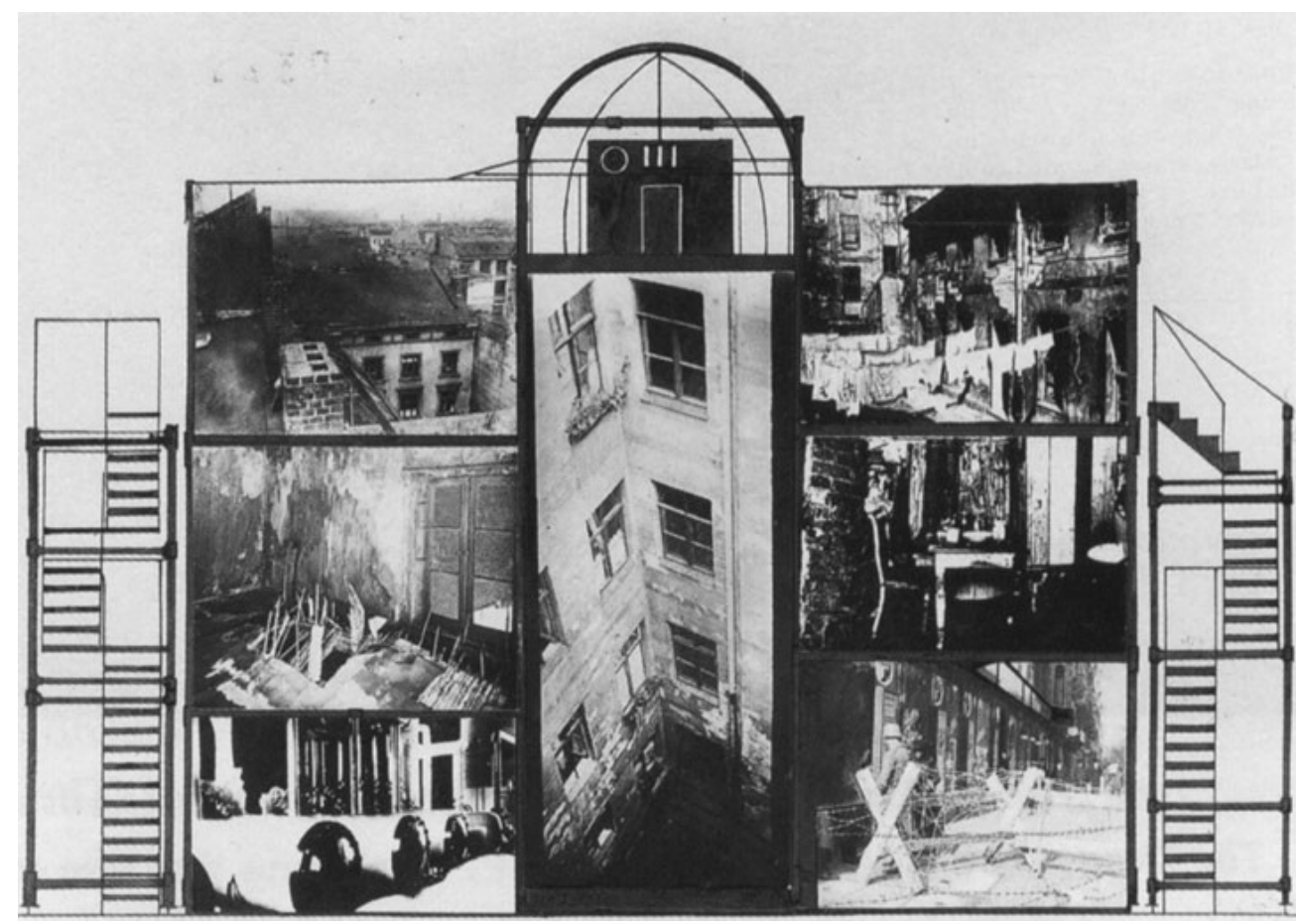

Fig.7. Fotomontagem do espetáculo Hoppla, wir leben!, por Ernst Toller, de 1927

Stationendramas (Dramas de estação) eram encenações que progrediam por meio de discretos episódios, semelhantes àqueles das ficções da hipermídia e de outras experiências on-line, incluindo aquelas que o surfar na rede faz. Parece-me apto e pertinente afirmar que esta estrutura episódica serviu a Piscator para criar uma das mais históricas estruturas precursoras do teatro digital.

Enquanto nos dramas da hipermídia (e nas obras de paixão medieval das quais, o termo dramático se deriva), as sequências individuais em Stationendramas suportam alguma conexão entre si, mas são distintas e não progridem através de uma lógica convencional, acumulativa, ou de uma estrutura dramática fluída. Nem são conforme as ideias aristotélicas de uma unidade de ação, tempo e lugar. As "estações" através das quais o protagonista expressionista progride (Karl Thomas no caso de Hoppla!) atuam como sinalizadores proféticos e encruzilhadas para onde as forças do destino, da escolha, da oportunidade, e a força humana convergirão. (DIXON, 2007, p. 45)

Para a produção de Piscator, o cenográfo Traugott Muller construiu um complexo de estúdios que compreendia seis salas alojadas em duas estruturas metálicas verticais, em cada lado de uma tela central de projeção. A decoração das salas estava distribuída com cortinas pintadas. Ao lado da mobília, filmes e slides se alternavam sobre telas transparentes, em locações de celas de presídios, salas-deestar, quartos de hotel e escritórios projetados por trás da tela. 
Esta técnica de usar a projeção em lugar dos tradicionais materiais cenográficos (madeira, tecido) tem sido usada para colocar atores dentro de mutáveis locações por toda a história do teatro multimídia, e tem alcançado novos avanços tecnológicos em desenhos digitais tridimensionais usados por companhias como a George Coates Performance Works.

$\mathrm{Na}$ tela central, narrativas de filmes, imagens de guerra, lutas de boxe, crises monetárias, dança e montagens de filme de notícias, foram algumas vezes projetadas durante a ação de palco. Em outras, constituiram um discreto interlúdio durante os blackouts entre as cenas.

Dois filmes especialmente produzidos abriram a temporada. O primeiro foi uma sequência editada de um filme de notícias, que justapunha a primeira Guerra Mundial à Revolução da Alemanha e incorporava tomadas de cenas especialmente filmadas de um ator desempenhando Thomas, locando-o como participante em ambos os eventos. Um exemplo de dinamização do tempo e do espaço:

\begin{abstract}
A tela em frente ao cenário subiu, as cortinas transparentes desceram para a projetada decoração, e a cena teve início. Um enorme relógio sobre a tela marcava intermitentemente a passagem dos anos de 1919 a 03 de novembro de 1927 - isto é, direto para a noite de abertura, uma outra oferta para a atualidade - enquanto novos flashes dos anos perdidos do personagem, Karl Tomas apareciam na tela. Eventos políticos como os levantes comunistas na cidade de Ruhr, Lenin falando para o povo, a ascensão de Mussolini, Sacco e Vanzetti, e a eleição de Hindenburg como Presidente da Alemanha, em 1925, foram pontuadas com fotos de pernas dançantes, lutas de boxe e a frivolidade dos anos 20. Som alto de jazz enfatizou a excitação do filme de oito minutos, e no final, a tentativa de Karl Thomas de se reabilitar, iniciou. (BAUGH, 2005, p. 62)
\end{abstract}

Piscator utilizou um conjunto de efeitos técnicos, incluindo transmissões de rádio muito amplificadas, e o uso da luz ultravioleta pela primeira vez no teatro que iluminou (apenas) o contorno do esqueleto branco desenhado nas costas dos trajes dos atores para uma dança de morte macabra, seguida de assassinato, coreografada pela célebre dançarina Mary Wigman. As cenas de filme rolaram por aproximadamente metade do tempo da produção total de Hoppla! e foram particularmente importantes para sua abertura e seções climáticas.

Na sequência da prisão do personagem Thomas, com a utilização das projeções foi possível exibir uma infinidade de celas de prisões e soldados marchando, para cima 
e para baixo, de modo opressivo tanto para a platéia quanto para os próprios prisioneiros. Na cena final, prisioneiros em diferentes celas, dentro do cenário de três fileiras, batem nos canos de ventilação para transmitir mensagens de um para o outro.

Transcrições de suas comunicações são projetadas em movimento sobre a fina tela transparente. Um clímax visualmente espantoso é alcançado com a projeção do filme Via Láctea, na seç̧ão central do cenário de 7,6m de altura, com uma densa e nebulosa explosão de estrelas. Nicholas Hern argumenta que, para Piscator, o uso do filme foi 'parcialmente devido à precisão do documentário e, parcialmente, para homenagear o complexo impacto de oito anos de avanço tecnológico na confusa mente de Karl Thomas'.

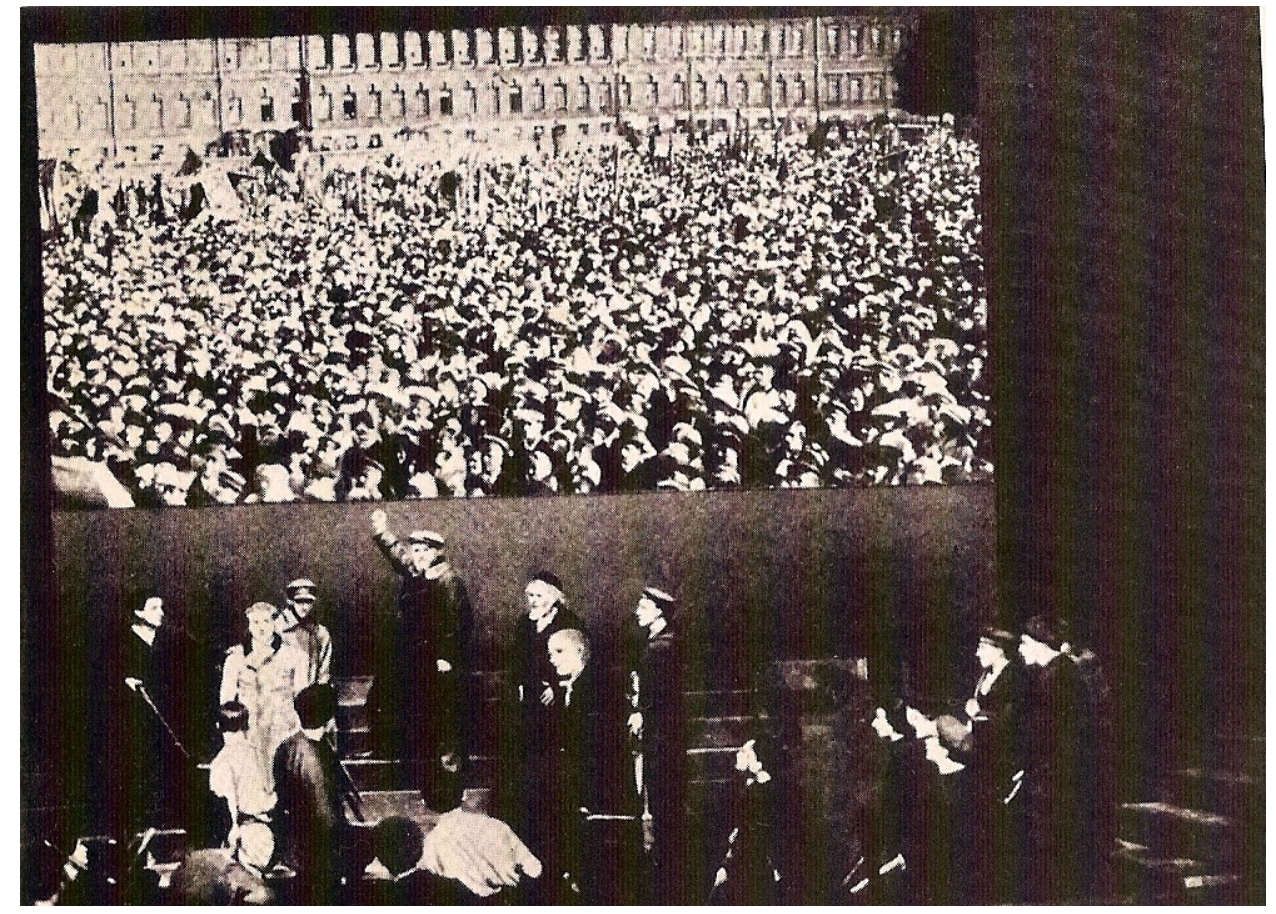

Fig.8 Cena de Raz-de-marée, dirigido por E. Piscator, no Teatro Volksbuhne, Berlim, em 1926. A projeção do filme insere dramaticidade a ação e faz um jogo complementar entre a cena e a imagem

Piscator sentiu que a sátira social de Toller não era suficientemente radical e utilizou o filme para fornecer o impacto político e dramático que faltava na obra (Fig.8). Embora reconhecendo a inovação e o impacto dos métodos de Piscator, a crítica adverte sobre o perigo que é a incorporação de filmes ao teatro, adotando um tom purista, típico de muitas críticas do passado e do presente:

O efeito pode ser usado na moderação para grande efeito (os métodos de Piscator eram uma sensação), mas além de um determinado ponto o método se torna um truque tão precioso quanto um Cinerama de 
brinquedo. Não é substituto para um bom drama, e as tentações que ele oferece para um sensacionalismo imaturo são somente aparentes demais. (GIESEKAM, 2007, p.27)

Toller era igualmente cético quanto aos efeitos do uso de filmes na produção de suas peças e, mais tarde, definiu as tentativas de Piscator para unificar o teatro e o filme como um erro, uma vez que considerava que as duas artes seguiam leis diferentes.

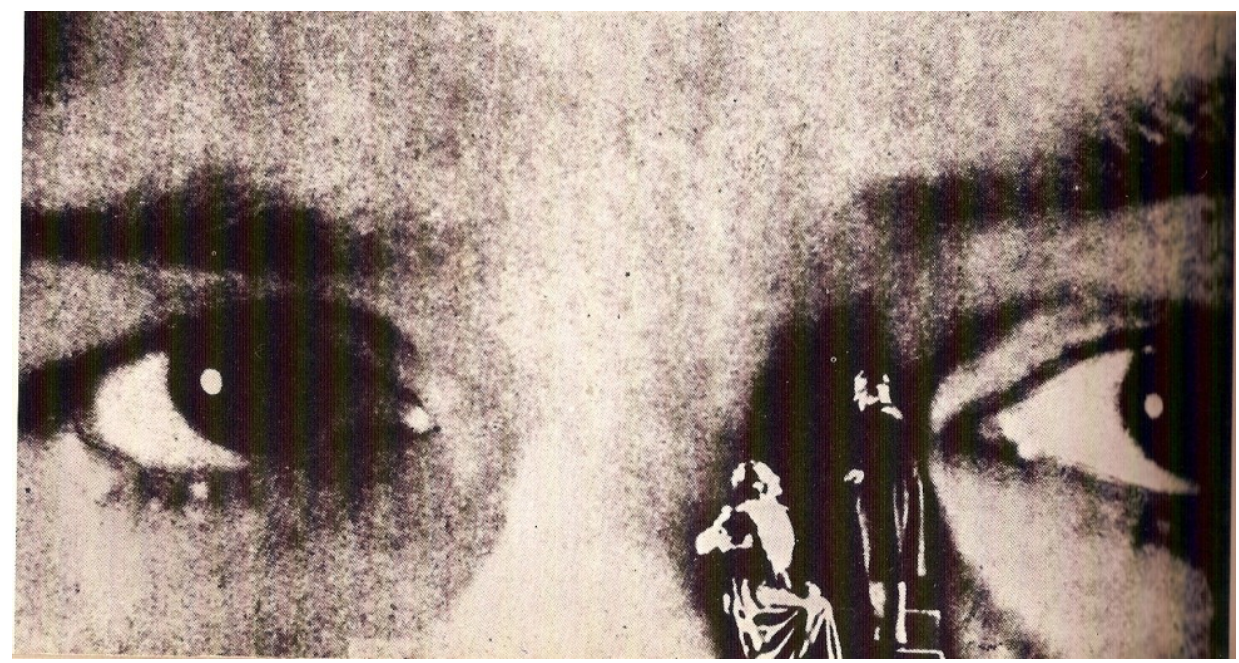

Fig. 9 Projeção com interação em cena em L'Eveil du Printemps, de 1936, direção de M. Kouril, encenada no Teatro Nacional de Praga

Referências críticas ao trabalho com cinema em teatro são raras nos trinta anos seguintes e parece que, depois de poucos anos de experimentação com filmes no final dos anos 20, o teatro retornou a suas tradicionais raízes vivas, com ocasionais e normalmente incidentais inclusões de filmes.

\begin{abstract}
O clima político dos anos 30 represou ou explicitamente reprimiu a atividade de vanguarda, com depressão econômica nos Estados Unidos e em outros países, a ascensão do fascismo na Espanha, Itália e Alemanha, e o decreto de Zhdanov, Ministro das Artes, em 1934, que a arte da Rússia deveria se dedicar exclusivamente ao realismo socialista. A partir de 1939, o trauma da II Guerra Mundial, e seus longos re-mapeamentos políticos e de reconstrução sócio-econômica, marcou um hiato de 20 anos no uso das tecnologias da imagem no teatro e, deveras, na vanguarda em geral. (GOLDBERG, 2006, p. 22)
\end{abstract}

Depois dos experimentos de E. Piscator, floresceram outras experiências pela Europa, com o uso de projeções em cena. Destaco as experiências das montagens L'Eveil du printemps, de 1936, direção de M. Kouril (Fig.9), encenada no Teatro Nacional de Praga, em que os espaços eram refeitos pela projeção de desenhos simples. 


\subsection{A Lanterna Mágika de Joseph Svoboda}

Em 1958, com a fundação da Laterna Magika, na Tchecoslováquia, hoje República Tcheca, por Joseph Svoboda (1920-2002) e Alfred Radok (1914-1976), o teatro multimídia começou, mais uma vez, a se desenvolver significativamente.

Inspirada pelo colega tcheco Emil Burian (1876-1926), que usava projeção de slides e filmes em suas produções do theatregraph, incluindo Spring's Awakening, 1936, de Wedekind, a companhia utilizou filmes em conjunção com múltiplas telas e efeitos de truques para criar ilusões e espetáculos de fantasia.

Complexos sistemas de telas, como polyscreen, foram desenvolvidos, em conjunto com esteiras rolantes e efeitos de luz difusa e direcional para atingir uma síntese teatral de imagens projetadas de atuação e encenação sincronizadas, possibilitando assim uma explosão na percepção espacial do espectador.

Em turnê pela Europa, em 1958, Svoboda e Radok transportaram palco e tecnologia de projeção. Pesando mais de 6800 quilos, incluindo dez diferentes tipos de telas móveis e duas esteiras rolantes que os levavam ao palco durante a apresentação. Para Svoboda, conjugar filme e teatro ofereceu uma forma de arte disciplinar, que expandiria as possibilidades dramatúrgicas e criaria novos significados e dimensões artísticas.

O equilíbrio entre as funções estética e dramática das duas formas foi fundamental para sua concepção, já que o trabalho dos atores não pode existir sem o filme e vice-versa. Um não é o plano de fundo do outro e a simultaneidade existente corresponde à fusão de atores e projeção: o filme tem uma função dramática.

Em sua detalhada atenção à escala e precisão do timing entre a ação de palco e a imagem do filme, Laterna Magika foi altamente influente ao demonstrar o potencial para a síntese visual do ao vivo e do gravado e das suas possibilidades narrativas e espaciais.

A companhia ocupa um lugar único na história do teatro multimídia, realizando alguns dos mais avançados e pioneiros experimentos direcionados a unir filme e atores. Cria um sentido de vivência que se origina na habilidade de ver a realidade a partir de diversos ângulos, em diversos níveis de tempo, conectando imagens que não podem ser unidas em nosso limitado mundo real. 


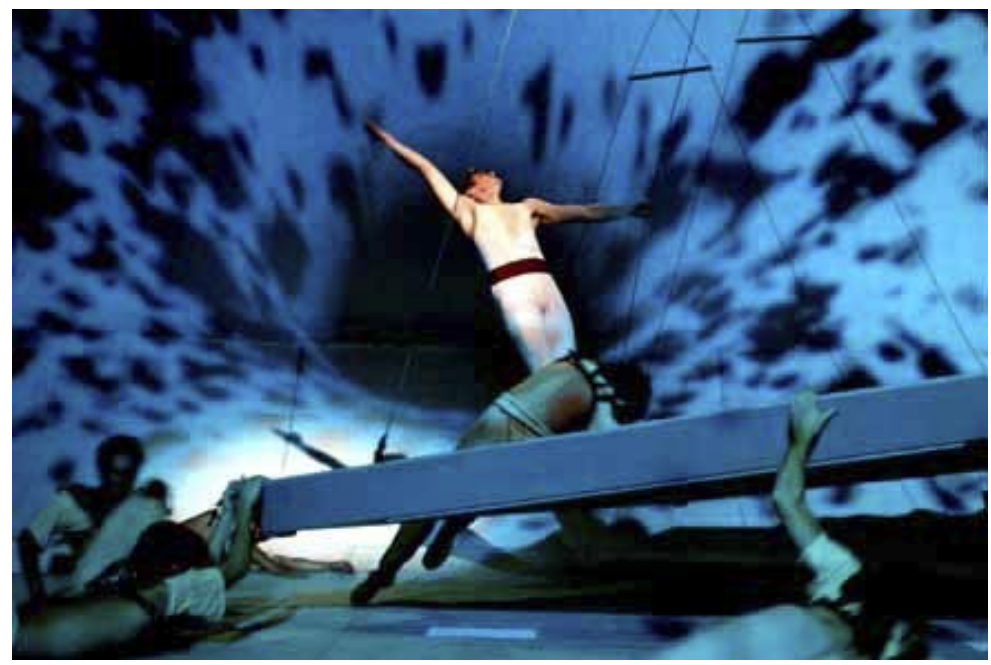

Fig. 10 Cena de Odisseus, direção de Josef Svoboda

Atualmente, a companhia continua em seu próprio teatro, no centro de Praga, com uma estrutura copiada por diversos grupos teatrais da mesma cidade. A produção Odysseus, de 1979 (Fig. 10 e 11), confirmou sua invenção visual na criação de um complexo narrativo teatral sem palavras, combinando dança, drama, projeção de filme e mecânicos efeitos de palco.

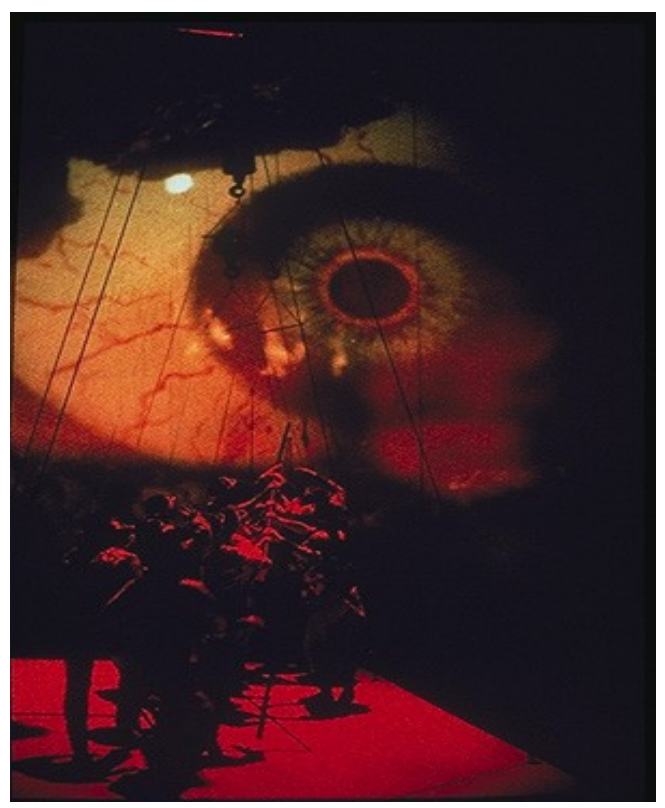

Fig. 11 Cena de Odisseus, direção de Josef Svoboda

Além dos trabalhos no grupo Lanterna Magika, Svoboda trabalhou com grandes diretores de sua época, por toda Europa. Um dos espetáculos mais importantes de sua carreira é o seu trabalho como cenógrafo em L'Instruction (O interrogatório), de 1966, 
com texto de Peter Weiss e direção de V. Puecher, no Piccolo Teatro, em Milão.

A partir de pesquisa feita pelo próprio Weiss sobre o julgamento de Nuremberg, o espetáculo mostra a sutil e genial forma de tratar o espaço por Svoboda. Com somente uma tela ao fundo do palco e toda a parafernália de edição à mostra à frente do palco, Svoboda usa o trilho de câmera entre o palco e a platéia para registar o espetáculo em travellings sequencias ao vivo e projetar imagens em cena.

Também usa close da câmera do próprio espaço teatral sobre os trilhos em movimento, para fazer uma alusão espacial e temporal aos trilhos dos trens dos campos de concentração alemães durante a Segunda Guerra.

O impacto é mais significante porque o espectador assiste a uma imagem sendo feita naquele momento. Projetado o trilho, o palco pode se transportar para outro espaço, mesmo que seja pelo uso de um símbolo simples (aqui, um trilho de câmera).

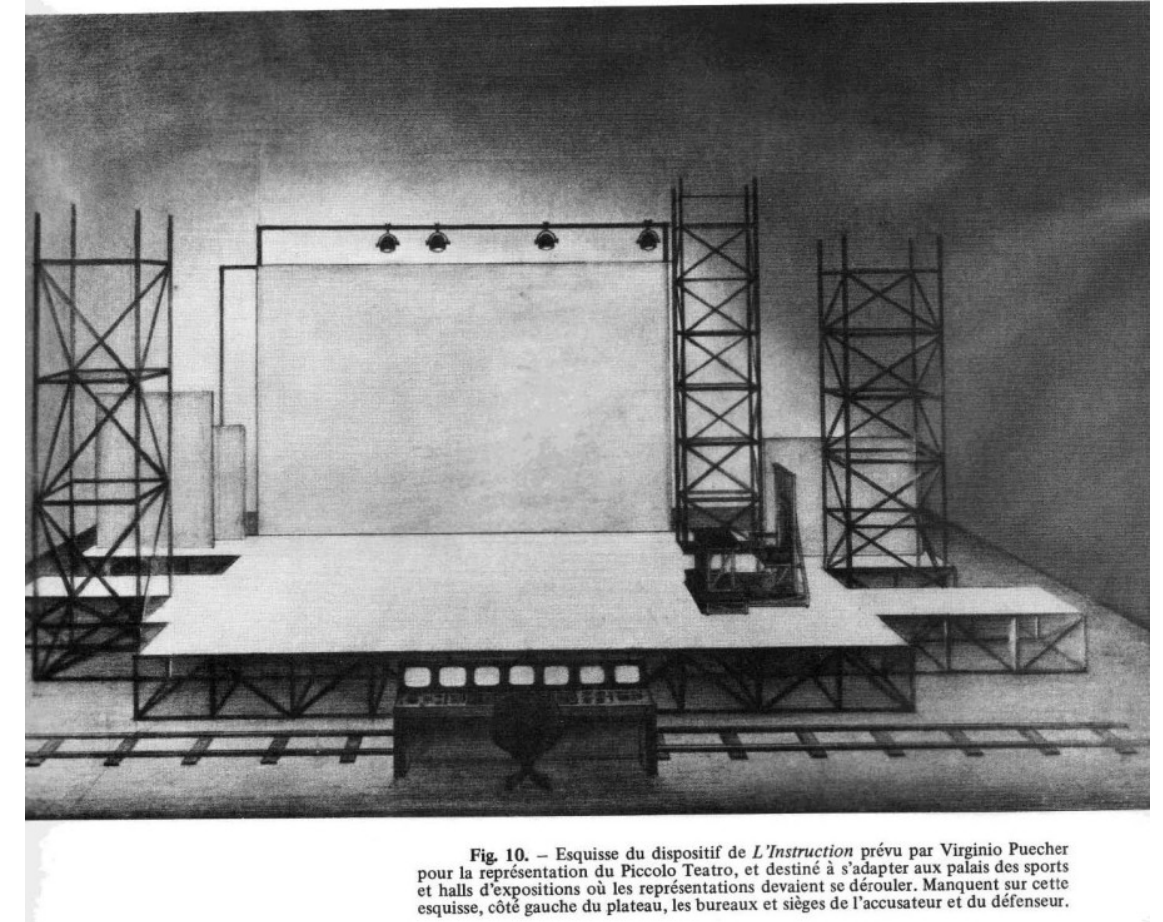

Fig. 12 Ilustração da cenografia de Svoboda para o trabalho L'Instruction, de 1966

\subsection{La Fura dels Baus}


No campo do uso das imagens tecnológicas temos a presença do grupo espanhol La Fura dels Baus ${ }^{16}$ que traz, não só em suas práticas, o uso cada vez mais ostensivo de imagens digitais em cena, além de carregar em seus trabalhos uma forte aliança da ação e do espaço. Criado em 1979, em Barcelona, o grupo nasce durante a efervescência cultural da transição democrática após a morte do ditador Franco, em 1975 .

Nesse solo histórico, La Fura passa por uma fase inicial de quatro anos de teatro em ruas e praças em Barcelona, que por sua vez passa por intenso processo de normalização linguística e de resgate da identidade catalã. Na sua primeira formação, tem nove homens responsáveis pelo grande rompimento com o teatro de rua e o salto artístico que se notaria nos primeiros três espetáculos (Accions - 1984, Suz/O/Suz 1985 e Tier Mon - 1988), ao fazer uso do hibridismo ou da mestiçagem artística que marcam as artes do século XX, de festas folclóricas da Catalunha, lutas, punk music, circo, butoh, happenings, body art e performance art.

\begin{abstract}
Evoluindo no solo as ações irrompem no meio da platéia a fim de produzir uma "alteração física do espaço". Trata-se, portanto de ocupar o espaço com a energia do corpo e conseguir a "vibração do agir plástico" sobre o único ponto fixo da cenografia, uma tela esticada sobre a superfície onde os atores fazem explodir, pelos seus gestos, as cores ligadas aos seus membros. A cenografia que explodiu em vários pontos no espaço, em seguida, centrase na tela, a criação de uma imagem pictórica: o quadro não importa, só importa o movimento expresso e impresso pelo corpo do ator sobre a imaculada superfície. A imagem pintada será tão efêmera quanto o gesto, o ato teatral em si, já que tudo será destruído no final do espetáculo por um ator em combinação, que virá lavar a tela e os atores com uma mangueira de incêndio. (PLATA apud VALLIN, 1998, p.206)
\end{abstract}

Mas é no campo das relações espaciais que o grupo se destaca, utilizando ruas e lugares inusitados, como estações de trem abandonadas e galpões. O grupo trabalha com a espacialidade expandida ao máximo, ou seja, com uma ação às vezes frenética e um aproveitamento total do espaço, em que não existem limites entre público e atores, afim de produzir uma alteração do espaço e de sua percepção.

Na década de 90 o grupo catalão inicia sua aventura pelo que, mais tarde, chamaria em seu Manifesto do Teatro Digital de interatividade e modificação da cena

\footnotetext{
${ }^{16}$ Fura em catalão significa furão, animal aparentado com fuinhas. El Baus era um córrego seco que virou um depósito espontâneo e anti-ecológico de lixo, na Catalunha, pequena cidade de 3000 habitantes a $60 \mathrm{Km}$ de Barcelona, onde três dos diretores naseceram e cresceram.
} 
tradicional por meio de videoconferências e da combinação de performances ao vivo e outras misturas com artes eletrônicas.

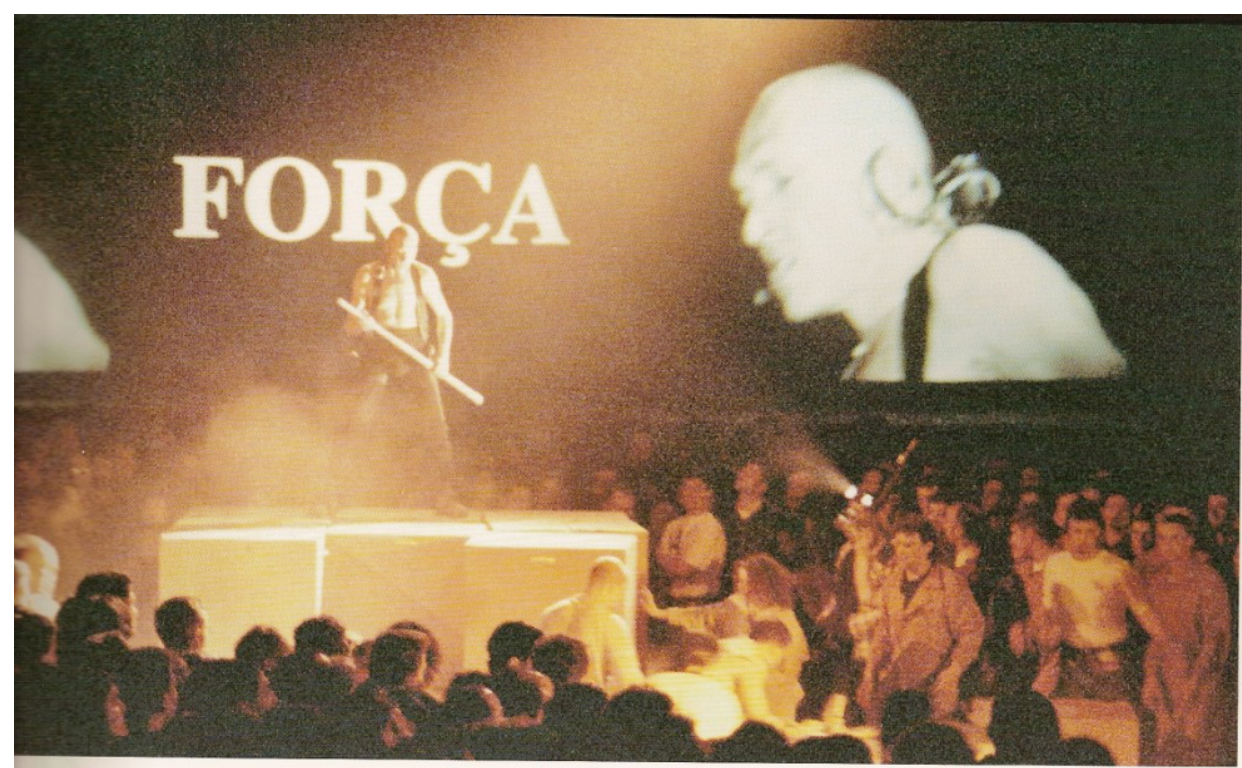

Fig.13 Projeções no espetáculo M.T.M. do La Fura dels Baus, em 1994

Dessa forma, propõe possibilidades infinitas de redinamização da espacialidade, seja pelo uso de imagens gravadas previamente em grandes telões que circundam o espaço do público e a ação cênica, seja pelas imagens ao vivo transmitidas e alteradas, dobradas, repetidas, falseadas por VJ. As possibilidades espaciais que se multiplicam, seja pelo público que se move por todas as direções, junto aos técnicos e atores, seja pelas possibilidades espaciais apresentadas nas grandes telas, utilizando muitas vezes recursos da computação gráfica, mesclando atores, formas e paisagens surreais.

La Fura parece responder à questão apontada de maneira diferenciada e contundente. Sua proposta de falta de barreiras entre o objeto que é observado, a obra, a criação, o palco, o mesmo, eu, e, do outro lado, o sujeito que observa, a assistência, a fruição, a platéia, o outro, ele ou ela, altera radicalmente a percepção habitual do teatro e do tema sendo abordado nessa outra proposição relacional e estética. As associações diretas das montagens fureras com a teorização de Lehmann sobre o pósdramático e teatro político continuam quando ele fala da necessidade de se alterar percepções habituais "nessa sociedade dominada pela mídia", afirmando que o teatro "oferece a alternativa de uma comunicação ao vivo e real", mas que "essa possibilidade de comunicação entre o espectador e o realizado, e o fato de o teatro ser esse cinema tridimensional, não é aproveitada", para concluir que "é justamente essa situação que é aproveitada por algumas dessas novas formas do teatro pós-dramático". La Fura parece aproveitar a situação apropriadamente e também servir como evidência clara. E o mesmo acontece quando Lehmann versa sobre o jogo e 
a categoria ética nessas outras formas de teatro. (PLATA apud VALLIN, 1998, p.216)

Em novas encenações realizadas no final da década de 90, o grupo continuou multiplicando suas atividades numa dinâmica estrutura, que pareceu por vezes perder a potência que existia nos trabalhos iniciais, justamente por conta do uso do vídeo. A radicalidade da ação e da criação de muitas nuances espaciais, agora com a presença do vídeo, se torna fria e falseada. O vídeo rouba umas das principais potencialidades do grupo: a presentificação/ação e radicalidade.

A interdisciplinaridade artística do La Fura não desrespeita nem contradiz o teatro. Tenta apenas dar um passo adiante, podendo ser considerado como ameaçador e/ou demolidor das fundações do teatro do século XX somente se teatro for entendido como uma arte que tem que defender fronteiras disciplinares e certezas absolutistas. Esta constante transformação pode desesperar aqueles que baseiam suas práticas em limites fixos ou no medo de assumir riscos e dúvidas, o que não é o caso nem de interdisciplinaridades artísticas nem de La Fura dels Baus.

\footnotetext{
No entanto, a prática do teatro de rua e a vontade de colocar em cena um dos elementos mais frágeis da representação teatral, a energia do ator, mostram que La Fura atribui mais importância ao movimento, ao vigor das ações que tem a capacidade de "fazer imagem". Além disso, a confusão do espaço teatral com o espaço de interpretação permite que nunca se definam as ações cênicas dentro de um quadro de cena tradicional em que o espectador poderá traçar as linhas de composição de uma imagem. Trata-se então, de uma relação aparentemente contraditória entre as "ações" que surgem do desempenho plástico e da imagem, entre a energia do ator que utiliza o espaço e a projeção sobre suportes fixos. A medida que as imagens projetadas ganharam destaque em seus espetáculos, a relação do público e da cenografia - os dois pilares da prática de La Fura dels Baus - foi alterada. (PLATA apud VALLIN, 1998, p.217)
}

O primeiro passo da evolução estética de La Fura dels Baus é lançado em 1994 durante a criação de M.T.M., com o conceito de 'teatro digital' em um texto teórico cujo objetivo era atualizar suas grandes linhas estéticas em que o espetáculo não seria mais elaborado a partir de um espaço físico, mas dependendo das combinações de 0 a 1 de uma memória digital, unindo e opondo, em um único movimento, conceitos ou de ação cênica, por exemplo, opor-se à singularidade da ação a sua dissolução no espaço, ou alternar, na mesma sequência, mau comportamento e intimidade. 


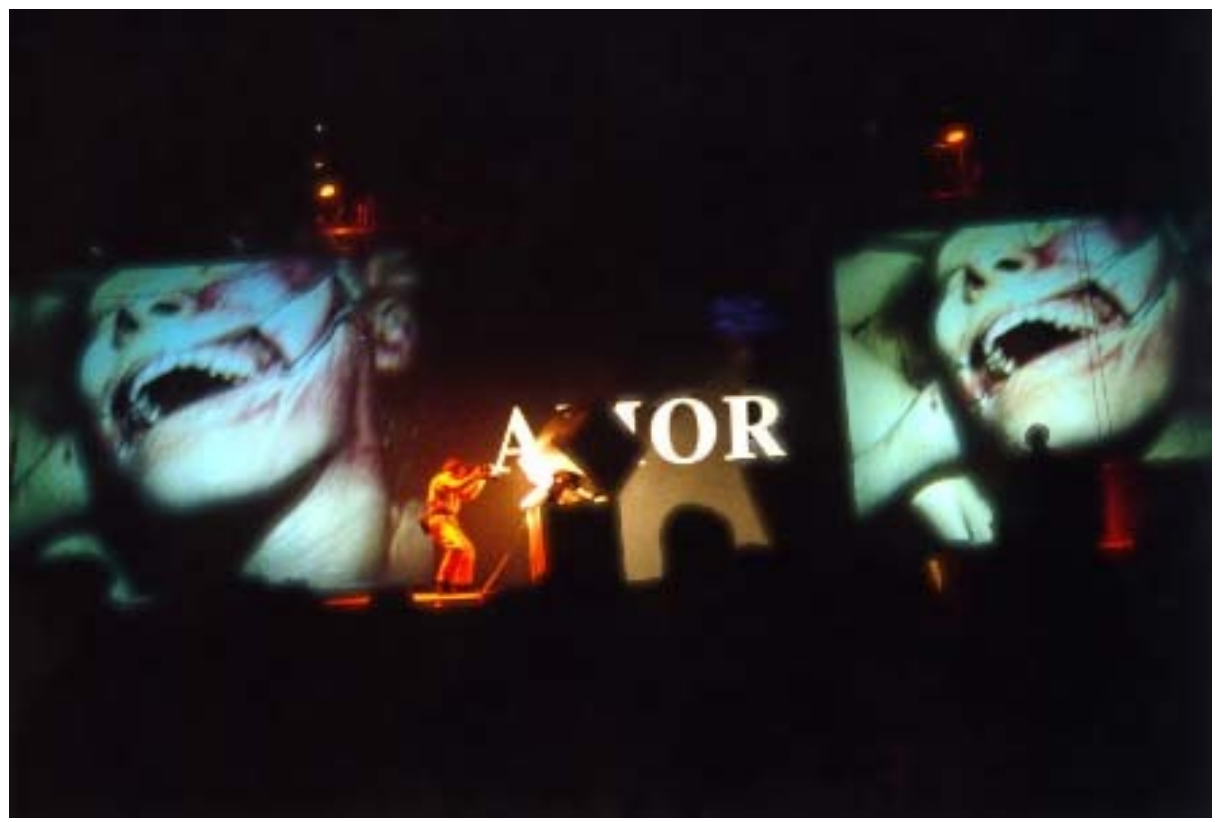

Fig.14 Cena de M.T.M. de La Fura Del Baus, em 1994

Em M.T.M. (Fig.13 e 14) uma tela central, altar da cerimônia-espetáculo, monopoliza a atenção do público com uma montagem acelerada das sequências dramáticas do espetáculo, que Ihe permite avaliar o que no espaço mostrado pelo vídeo "ao vivo" e exibido durante a performance, nem sempre o que se vê é real, pode ser manipulado e alterado.

Sequências que ocorriam em meio ao público eram transmitidas de forma documental nos telões porém, muitas vezes modificadas, dando a impressão de verdade alterada, pelas mãos da mídia (VJs). Até em uma cena em que o grupo fazia uso de grandes espelhos laterais, as imagens vistas eram distorcidas, refletindo claramente uma vontade anárquica de se refazer o espaço e a ação da cena, possibilitando outras visões, muitas vezes assustadoras.

Tal como no auto sacramental do drama barroco espanhol, é preciso estar fora do âmbito da ilusão para explicar o "senso moral e religioso" da obra, embora aqui o espetáculo se recuse a emitir uma mensagem clara. No entanto, independentemente da complexidade dos dispositivos utilizados, o ator continua a determinar as zonas de representação pelo seu deslocamento que, por sua vez, motiva o deslocamento do público.

Entre os dois textos teóricos de La Fura dels Baus (Manifesto Canalha e Le Théâtre digital), dez anos se passaram sem que o tratamento dos elementos da 
representação fosse alterado: a apropriação do espaço pelos atores, como a manipulação do público, continua a ser a marca do grupo.

Os elementos tecnológicos, tanto as máquinas como o vídeo são adicionados a uma prática "aglutinante" e empírica através da cenografia. Esta abordagem é especialmente importante pois La Fura dels Baus cria a seus espetáculos em torno de várias "ações" motivados por impros ${ }^{17}$, que podem ser desenvolvidos a partir de objetos. (PLATA apud VALLIN, 1998, p.210)

Mas a introdução da imagem impõe um quadro fixo para um grupo que privilegia a explosão no espaço e a simultaneidade temporal das ações, com sequências onde o vídeo colabora nos efeitos de ilusão, em outro em que apenas exibe o que acontece num extremo do espaço. A visão da totalidade do espetáculo nem sempre é possível devido à caótica movimentação de todos e ao vídeo que opera também como um manipulador do espaço: traz a cena para todas as paredes. O vídeo impõe aos espetáculos seguintes de La Fura dels Baus um único foco, ainda que as dimensões da imagem possam explodir graças à utilização na cena de uma grande tela, como em M.T.M. e na maioria de seus trabalhos futuros.

Com M.T.M. La Fura dels Baus dá um salto para a revolução virtual. Na verdade, imagem e vídeo são apenas elementos da cenografia que constituem a matéria do espetáculo em si: as telas, de 12 metros cada uma, colocadas em três paredes laterais, são o meio de difusão de muitas das imagens, espaços e nuances importantes do espetáculo. As três telas, com a instalação de vários espelhos em ambos os lados, entornam o espectador em um dispositivo em ' $U$ ' que multiplica as imagens projetadas. O público, que podia circular à vontade, era bloqueado dentro de um quadrado por esse dispositivo e todos os olhares convergiam para o altar desta catedral-discoteca: a tela era o lugar do rito da Eucaristia nesta versão moderna do Grand Théâtre du monde, de Calderón.

Com a tela, o público parece mais motivado a interagir neste momento do que antigamente. Um VJ mistura as imagens filmadas ao vivo por um cameraman que

\footnotetext{
${ }^{17}$ Impros são croquis na mesma direção e com uma natureza subjetiva, produzidos pelos membros do grupo para causar ou estimular uma ação. Exemplo de impro para o espetáculo Tier Mon - Modules escenographiques: móveis, cobertos/descobertos, grande/pequenos. Entro no espaço de interpretação e o vejo iluminado, os módulos empurrados contra a parede começam a circular para uma causa particular; o movimento é criado pelos atores ou motores acoplados a cenografia.
} 
segue os atores com outras imagens gravadas. E mostra ao espectador as imagens montadas a partir das diversas fontes que vêm ao computador.

A tela não é apenas o suporte da imagem projetada, um elemento cenográfico, mas um elemento dramático: às vezes ela suplanta as ações realizadas pelos atores ou a música, que foi muitas vezes a espinha dorsal do espetáculo.

Até a introdução das imagens, a cenografia era o eixo sobre o qual La Fura dels Baus construiria seus espetáculos. A imersão de todos os elementos cênicos para o público sempre foi um importante elemento de sua estética. As imagens e o vídeo não estão envolvidos nesta qualidade imersiva ou mobilidade que antes afetaria o elemento cenográfico.

Em M.T.M., essas características concernem apenas às ações dos atores, os seus movimentos, inclusive à construção de diferentes dispositivos preparados com cubos de papelão com um volume de $80 \mathrm{~cm} 3$. Além disso, a tela tinha uma função dramática autônoma: por exemplo, com as projetadas cartas de baralho nas quais os rostos são os rostos dos atores que se tornam personagens arquétipos, ou seja, os protagonistas de diferentes partes do espetáculo correspondentes a três encenações, três tipos de poder, de política, de religião e de economia.

Em outras cenas, em que não mais existia a pirâmide cenográfica feita de cubos de papelão, as imagens da pirâmide retornavam, assim como outros signos de espaço e imagens diversas, em close-ups. Um dos momentos onde a questão do vídeo se faz mais criativa é quando um grande muro de blocos cenográficos divide literalmente a plateia em duas partes, e cada lado acompanha o que ocorre com o outro, somente por meio das transmissões feitas ao vivo nos telões laterais de sua parte.

Mas o que se observa são cenas falsas da outra metade da multidão, que é sumariamente metralhada. O massacre falso cria uma terceira dimensão de espacialidade e, ao mesmo tempo, corrobora a ideia do espetáculo que tange às manipulações das mídias nos dias de hoje.

Em Noum alguns elementos, como a machina máter e a tela com os espelhos, funcionavam como os principais elementos da fábula, enquanto outros, como as plataformas motorizadas e os cubos de papelão, eram suportes utilizados pelos atores durante a performance. 
Esta evolução na cenografia motivou um novo comportamento no público, cujo deslocamento tem sido até agora determinado e provocado pelos atores. Se em Noun os olhos da máquina não mobilizavam toda a atenção do público, em M.T.M., contudo, a tela atraiu facilmente os olhares dos espectadores. A elevação da tela acima do solo, na altura em que os atores encenam, e suas dimensões são, sem dúvida, os dados que levaram o público a buscar na imagem projetada o que não podia ver no desenrolar de certas ações.

Pode ser constatado que o impacto das imagens na estética furera vai além de uma simples evolução tecnológica da cena e é um conjunto de investigação, assim como um motivo de explosão e uma razão para a cisão. A partir desta experiência, o uso de imagens não é unanimidade no grupo, apesar de dois membros da La Fura, Carlos Padrisa e Alex Ollé, terem continuado a trabalhar com as imagens.

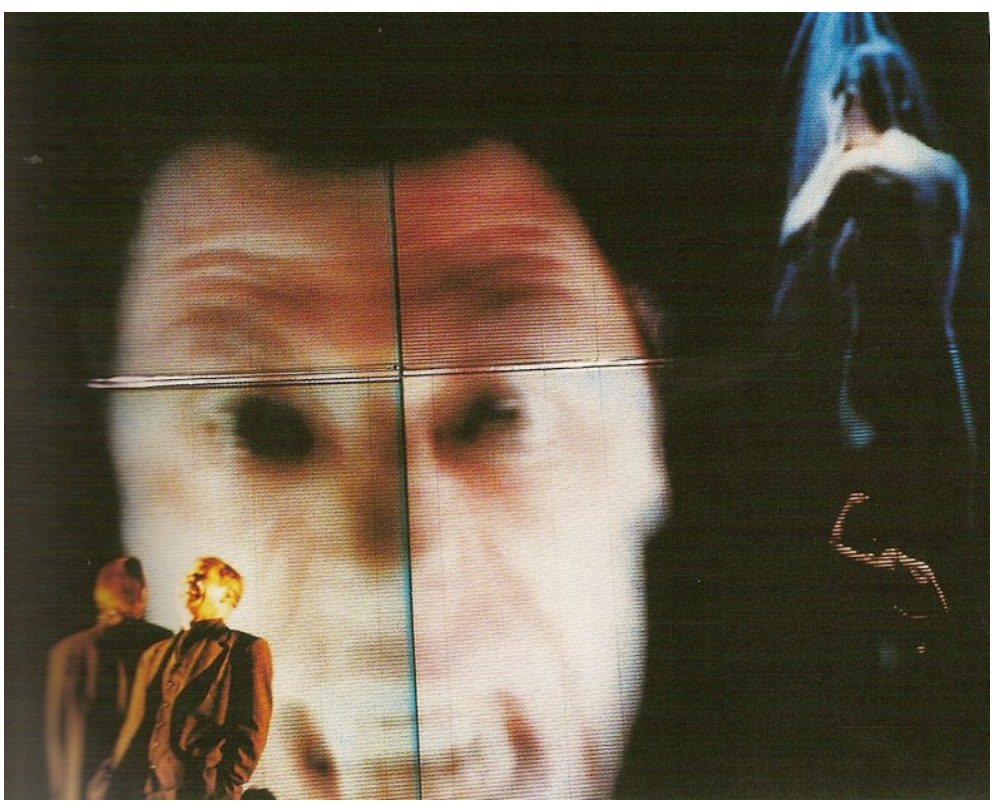

Fig. 15 Interação com vídeo no espetáculo F@ust 3.0, de 1998

Embora La Fura dels Baus muitas vezes exclua o texto dramático, a imagem tecnológica, no seu sentido mais amplo, não deixa de ser o núcleo de sua linguagem. 0 espaço e, sobretudo, a ação são os dois eixos de uma constante busca pelo efectismo ${ }^{18}$. A linguagem de La Fura encontra o seu material em uma constante observação e

\footnotetext{
${ }^{18}$ O grupo inventou este termo para a construção do código estético da soma das impressões produzidas sobre o público fora da fala com o impacto exercido durante a representação.
} 
manipulação da recepção do espectador. A energia e o poder, reivindicados como marca da sua linguagem, são formas de criar o efectismo furero.

Nos trabalhos posteriores nascem as imagens a partir da interação entre os atores e o vídeo, oferecendo a continuidade de uma realidade física na sua simulação eletrônica (Fig.15 e 16). Os monitores serão, então, uma janela aberta a todas as possibilidades de um corpo real limitado no seu movimento ou em seu esforço.

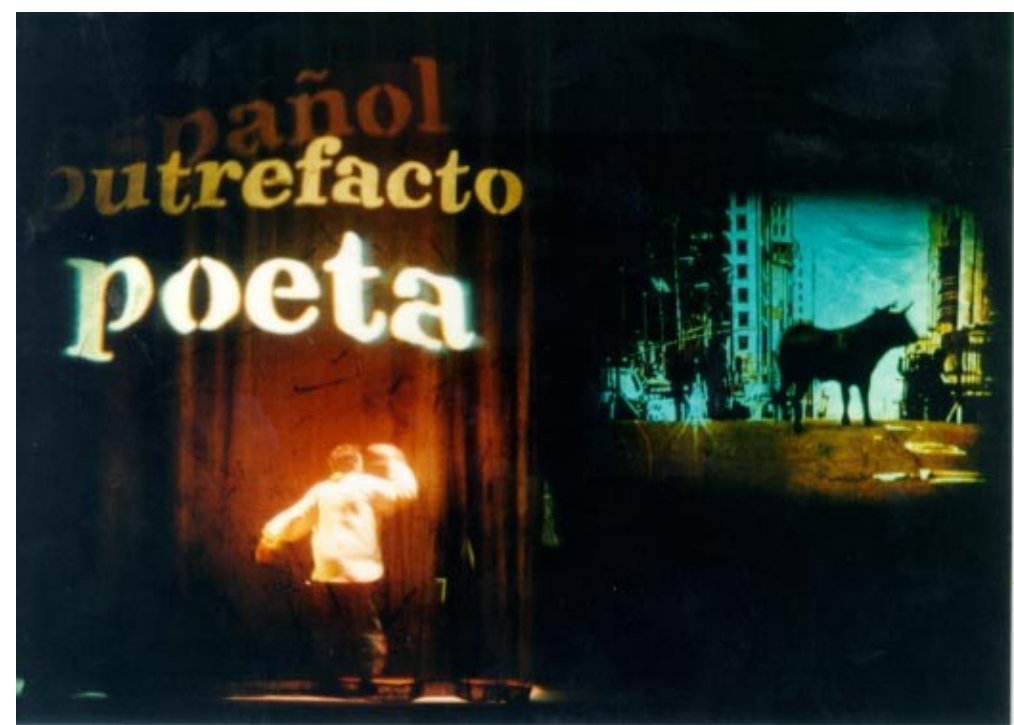

Fig. 16 Interação com vídeo no espetáculo F@ust 3.0, de 1998

A imagem do vídeo traduz os elementos de sua própria língua, substituindo o espaço físico por um espaço virtual, e a energia é expressa por uma força especial, por meio de uma montagem rápida e irregular. A seguir, temos o texto intitulado El Teatro Digital, disponível no site oficial do grupo, que de certa maneira abraça as convicções e os objetivos estéticos do grupo La Fura dels Baus em relação à tecnologia:

¿Por qué Teatro Digital? El teatro del fin del milenio ha abandonado su vieja concepción genetista (desde la fecundación por un tema hasta el parto de la puesta en escena), y la ha sustituido por una organización de experiencias interactivas y, con frecuencia, interculturales. En los años 90, la idea de interactividad ha modificado la puesta en escena tradicional y ha dejado paso a video-conferencias o a la combinación de performance en vivo con otras de tipo electrónico.

La noción de Teatro Digital también se refiere a un lenguaje binario que relaciona lo orgánico con lo inorgánico, lo material con lo virtual, el actor de carne y hueso con el ciberactor, el espectador presencial y el internauta, el escenario físico y el ciberespacio...

De la misma manera, el Teatro Digital puede romper con la jerarquía sexual imperante. El deseo sexual, la libido, se viste y se cubre de nuevas imágenes para tejer la autosatisfacción de los cibernarcisos. Un teatro interior en el que el sueño deviene realidad (virtual).

En este sentido, el Teatro Digital se multiplica en miles de 
representaciones singulares y, paradójicamente, los ciberteatreros pueden desplegar imágenes de su propia subjetividad en el interior de mundos virtuales compartidos.

En el Teatro Digital conviven la abstracción absoluta con el retorno al cuerpo, que puede adquirir una dimensión sado-masoquista, sensual, angélica, orgiástica, o quizá una mezcla de todas ellas. Un cibercuerpo que también comporta una cibersexualidad.

Pero el acto en vivo ofrece un cara a cara, una confrontación con el espectador con la que es difícil rivalizar. Porque el ritual todavía es posible, los límites pueden cruzarse...

Por definición, el acto teatral siempre comporta un exceso, un plus de re-presentación. Es el placer de mostrar, de mostrarse. Entre el actor y el espectador se establece una corriente de identificación. ¿Se identifican ustedes? ¿Cómo se ejerce esa identificación en el Teatro Digital? ¿Como una mano que entra en un guante? ¿Como un pie que encaja en un zapato? ¿Como una prolongación de uno mismo? ¿Con la integración en la red?

Ciertamente, la tecnología digital hace posible el viejo sueño de trascender el propio cuerpo. Así, el ciberespacio puede poblarse de cuerpos humanos en un nuevo envoltorio representacional, disgregando subjetividad y materialidad. Salir de la propia piel para adentrarse en una referencia perceptual común. Los roles de actor, autor y espectador tienden a confundirse. Podemos aventurar que en el siglo XXI, la conciencia individual se integrará cada vez más en una colectividad. Sin ir más lejos, Internet es la visualización de este pensamiento colectivo, orgánico y caótico que ha ido desarrollándose sin jerarquías definidas.

Y si la cultura emergente del próximo milenio trasciende los ámbitos de la biología, de la informática y de la ecología para fundirlas en una cultura de la complejidad, la representación escénica tendrá que adaptarse a estos nuevos parámetros aunque, repetimos, la idea de Teatro seguirá siendo una maravillosa metáfora para la sociedad futura. En ese sentido, el Teatro Digital cataliza la transición entre la escena del siglo XX y la del XXI. Por otra parte, la cultura digital aporta una novedad puesto que no pertenece a una tecnología de la reproducción, sino de la producción inmediata. Así, mientras la fotografía hablaba en pasado, al congelar un instante ya vivido ("esto fue así"), la imagen digital lo hace en presente: "señores y señoras, esto es así". Hermanándose de este modo con el acto en vivo, con el teatro, con el aquí y el ahora.

En fin, XXX es una propuesta interactiva que permite mutar la imagen, haciéndola pasar de una figuración a otra -virtual y presencial-, situándola en escenarios diversos. La suma de todas estas imágenes es la que proporcionará un icono de síntesis de este nuevo teatro que seguirá siendo, sobretodo, HUMANO. 


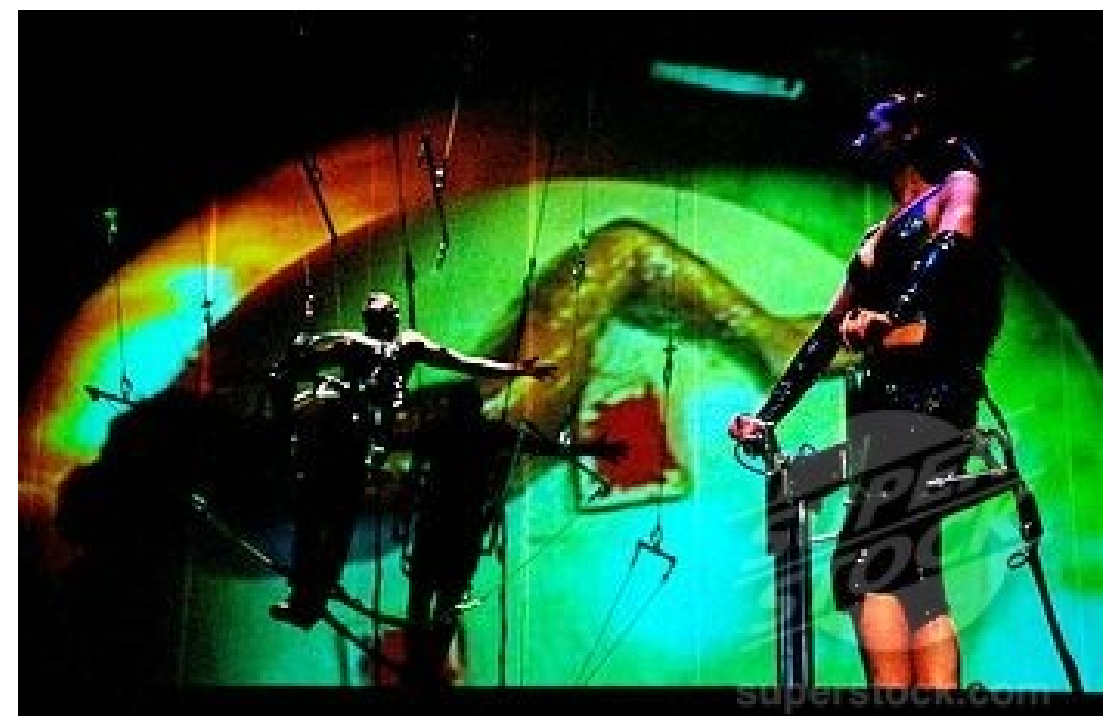

Fig.17 Cena do espetáculo XXX, do grupo La Fura dels Baus

Em 2003 o grupo realiza XXX (Fig.17), espetáculo que explora cenas de sexo explícito, inspirado em A Filosofia na Alcova, obra do Marquês de Sade, de 1795, convidando o público para cenas em espaços obscuros do cenário. Em entrevista, Valentina Carrasco, integrante do La Fura dels Baus, menciona que o uso do erotismo neste trabalho joga essencialmente com o que está presente na obra, a incitação à simulação sexual do prazer, o que leva as pessoas a pensar em Sade como um escritor erótico, que verdadeiramente não é: sua obra realmente recorre a elementos eróticos, mas como um meio, não como uma finalidade.

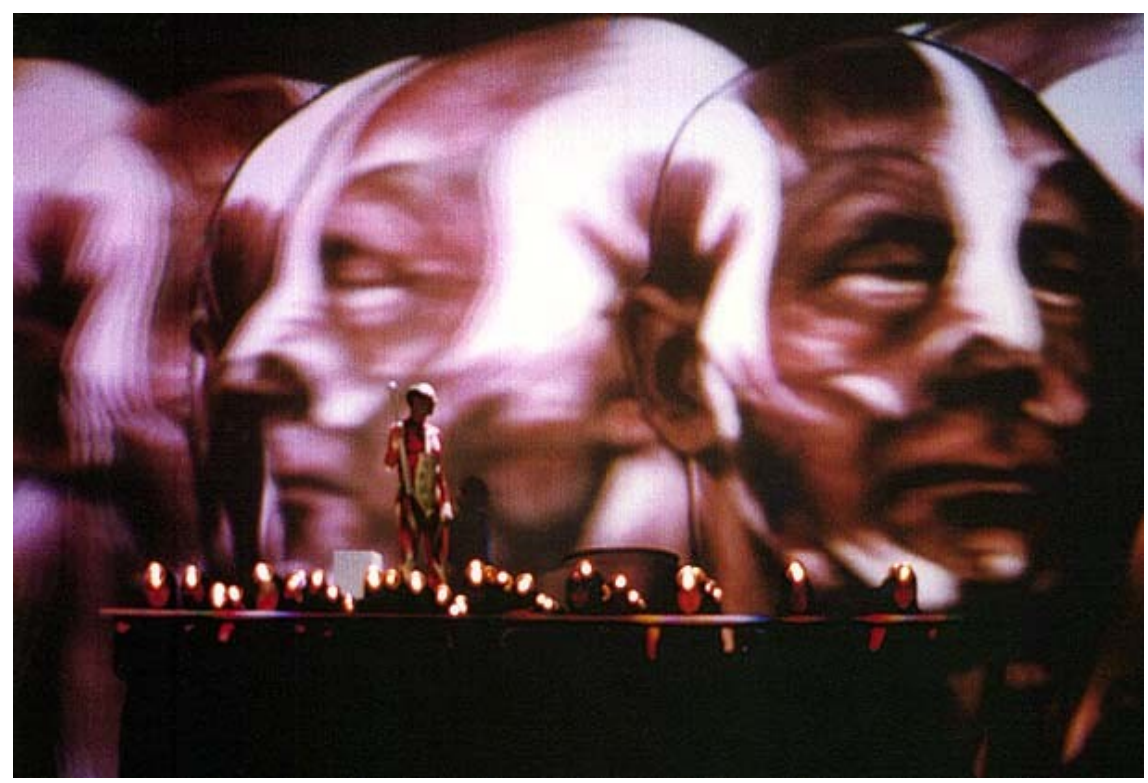

Fig. 18 Cena do espetáculo El martiri de sant Sebastiá, do grupo La Fura dels Baus 
O que mais conservamos sobre Sade é esse confronto com as normas por meio de um erotismo forte, da sensualidade, do prazer táctil. A obra explora vídeos gravados com atores pornôs que participaram do processo e os atores do grupo simulam sexo em cena, de forma a confundir os limites entre cenas reais e simuladas (com imagens pré-gravadas e próteses para simular uma penetração sexual real).

Na peça, a jovem Eugéne responde a um anúncio para participar de um filme pornô e é iniciada sexualmente por um trio de devassos. Segundo Teresa Vallejo (Fig.19), o trabalho acaba por exigir bastante deste trio de atores, conforme comentário a seguir:

Foi difícil, já que não sou uma atriz pornô. Minha formação é de teatro clássico e dança. O processo todo durou seis meses, tempo necessário para que o elenco se adaptasse, e o resultado final só se deu porque havia grande respeito e amizade entre nós. (GARCEZ, 2003, p. 47)

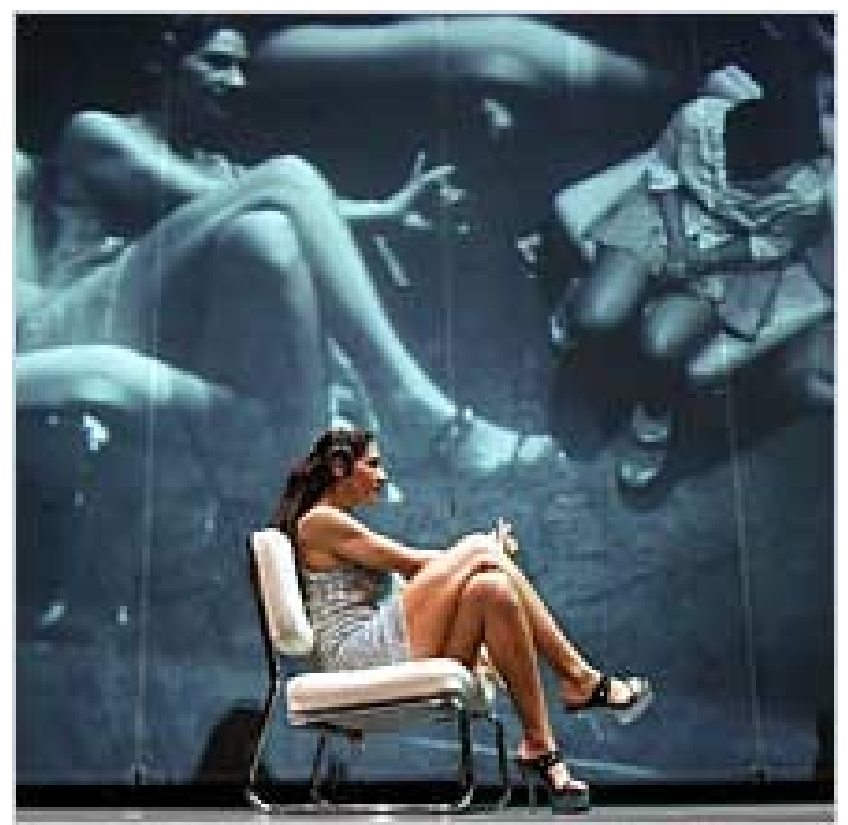

Fig.19 Cena do espetáculo XXX, do grupo La Fura dels Baus

A peça teve, como se poderia esperar, uma repercussão conturbada: muitos protestos da igreja católica, proibição em diversos países e a divisão da opinião pública por tratar o sexo de forma datada para alguns, ou ainda parecer algo novo para outros. Para o diretor Carlos Padrissa XXX foi 'uma peça extremamente pedagógica. Ela não 
buscou fazer com que você fique excitado enquanto a assiste, mas sim que depois, em casa, com sua companheira, você possa se abrir e pensar sobre ela ${ }^{19}$.

\subsection{La Fura dels Baus - Óperas}

A ópera, como um desempenho total, requer tratamento em profundidade de todo o seu potencial. Embora o lado musical da ópera tradicionalmente tenha ensombrado os seus aspectos teatrais, nas últimas décadas, com base em abordagens como as adotadas pela La Fura dels Baus, o gênero tem sido alvo de uma profunda mudança. La Fura optou pelo uso de dispositivos audiovisuais para as configurações de palco gerador e usos alternativos dos papéis dos cantores, atores e coros o que definiu o seu estilo próprio na seara das óperas. As incursões do grupo catalão pelas óperas incluem Atlantida, de Manuel de Falla; O Martírio de São Sebastião, de Claude Debussy; A Danação de Fausto, de Hector Berlioz; e DQ Don Quixot em Barcelona, por José Luis Turina.

Em março de 2002, com o primeiro-ministro de On the Marble Cliffs, em Mannheim, baseado em obra homônima de Ernst Jünger, temos o registro do primeiro uso da videoconferência como elemento de estágio em uma ópera. No mesmo ano estreia a encenação do fantástico Hector Berlioz, Sinfonia de La Fura dels Baus, apresentado pela primeira vez em Palermo como releitura de uma obra clássica da música sinfônica. Em 2003, em Bochum, o grupo lança na Trienal de Ruhr A Flauta Mágica de W. A. Mozart, relançada em 2005 na Ópera de la Bastille em Paris e no Teatro Real de Madrid.

O grupo trabalhou também no não convencional e sempre em áreas de risco do drama escrito ou estilo italiano de teatro, como o F@ust3.0, um programa (turnê internacional encerrada em outubro de 2004, após três anos de trabalho) que percorreu obras clássicas de Goethe, Ombra e releituras de vários textos de Federico García Lorca. No campo do teatro clássico, cito a versão de $O$ Eurípedes com Mulheres de Tróia, de setembro de 2001, dirigido por Irene Pappas e La Fura dels Baus, com

\footnotetext{
${ }^{19}$ Padrissa é um dos fundadores do La fura, atualmente dirige as montagens do grupo que exploram com mais intensidade a aplicação de recursos tecnológicos
} 
música de Vangelis e cenografia de Santiago Calatrava, encenada em Sagunto (Valência).

O mundo das óperas tem tido grandes inovações cênicas, e grandes diretores de cinema, shows e teatro têm sido convidados para dirigir espetáculos não distantes das tecnologias da imagem. Não foi diferente com o tour de force do grupo La Fura dels baús, e o diretor que mais integra imagens tecnológicas a seus espetáculo, Carlos Padrissa, que se juntou ao maestro Zubin Metha e remontou a quadrilogia do 'Anel', de Richard Wagner, uma das óperas mais longas ainda apresentadas.

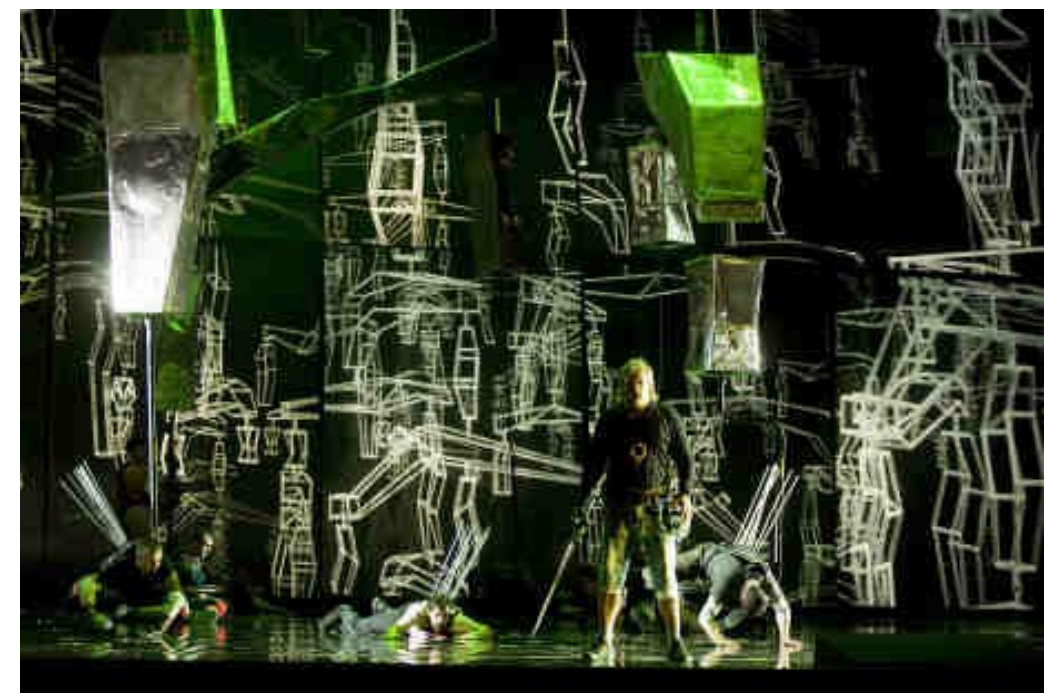

Fig. 20 Montagem da ópera 'O Anel de Nibelungo', de Richard Wagner, pelo grupo catalão La Fura dels Baus sobre direção de cena de Carlos Padrissa e regência de Zubin Mehta

A obra Der Ring des Nibelungen (O Anel dos Nibelungos) é uma tetralogia de quatro óperas, baseadas na mitologia germânica, que levou vinte e seis anos para ser completada, exigindo cerca de quinze horas para ser executada (Fig. 20 e 21). Ela é composta por Das Rheingold (O Ouro do Reno) (1853-1854), Die Walküre (A Valquíria) (1854-1856), Siegfried (1856-1857 e 1864-1871) e Götterdämmerung (Crepúsculo dos Deuses) (1869-1874).

Com ostensivo uso de telões de LED, com imagens que a todo momento traduzem espaços e sensações dos personagens de Wagner, Padrissa consegue mesclar formas, criaturas e personagens fantásticos propostos por Wagner com seres digitais que dialogam, ou melhor, cantam junto ao elenco ao vivo. 


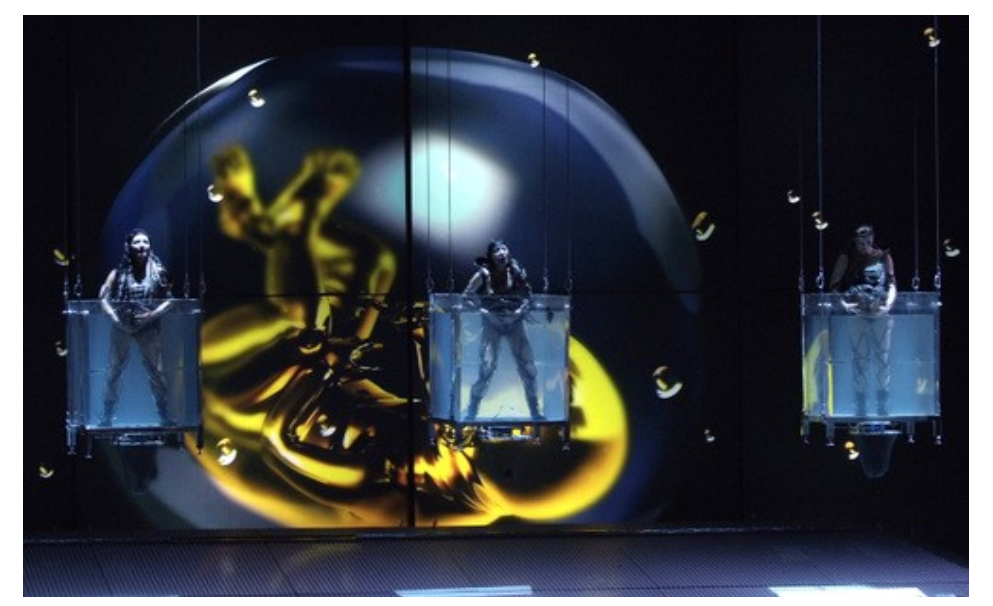

Fig. 21 Montagem da ópera 'O Anel de Nibelungo', de Richard Wagner, pelo grupo catalão La Fura dels Baus sobre direção de cena de Carlos Padrissa e regência de Zubin Mehta

Trata-se de uma experiência radical no uso de imagens tecnológicas em cena de ópera, pois o vídeo segue por muito tempo paralelo às arias, sincronizando trechos e elevando alguns momentos clássicos da obra com ares bem mais contemporâneos e digitais, sem perder o deslumbramento da musicalidade de Richard Wagner.

Um dos últimos trabalhos do grupo espanhol a dialogar com as imagens tecnológicas é o espetáculo Sonntag, do ciclo Licht, um espetáculo de dança, música, teatro e multimídia, acompanhado pela simulação de sons extraterrestes (Fig. 22). A Ópera foi criada por Karlheinz Stockhausen, um dos mais importantes compositores do século XX e para muitos é objeto tanto de culto quanto de controvérsia. O pioneiro da música eletrônica influenciou os caminhos não apenas da tendência erudita, como prova sua presença na capa do legendário álbum dos Beatles Sgt. Pepper's Lonely Hearts Club Band.

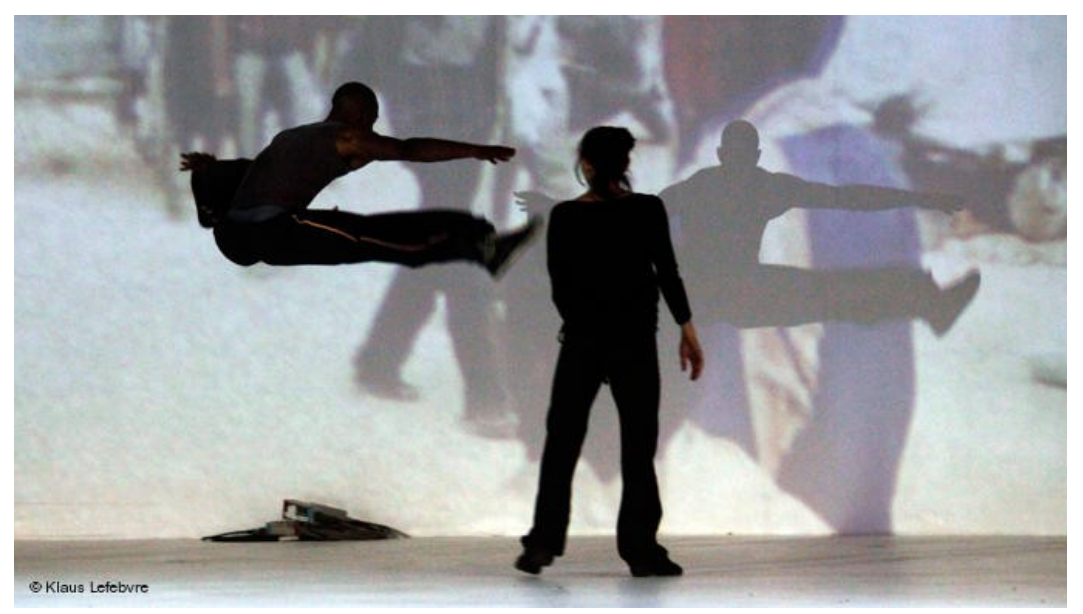

Fig. 22 Cena de Sonntag, de Karlheinz Stockhausen, direção de Carlus Padrissa, da trupe catalã La Fura Dels Baus 
O trabalho em vídeo também serve para transfigurar, separar e criar novos espaços. A cena final (quinta cena de Sonntag, também considerada cena-chave, leva o nome de Hoch-Zeiten - jogo de palavras entre casamentos e tempos altos) era executada simultaneamente em dois locais: Hoch-Zeiten für Orchester na sala B e Hoch-Zeiten für Chor na sala A.

Com o som de cada sala transmitido para a outra, o público era dividido em duas partes. Uma parte sentava-se na sala da orquestra em que cinco grupos instrumentais e cinco regentes apresentavam uma música francamente sensual. $\mathrm{Na}$ sala do coro, em que foram retiradas todas as cadeiras, cinco grupos de dançarinos circundam o público de pé ao som de solenes cantos corais. Projeções de vídeo mostravam por vezes um bazar árabe, por vezes a Catedral de Colônia, e após a última nota e uma breve pausa os espectadores trocavam de posições e a sequência era repetida.

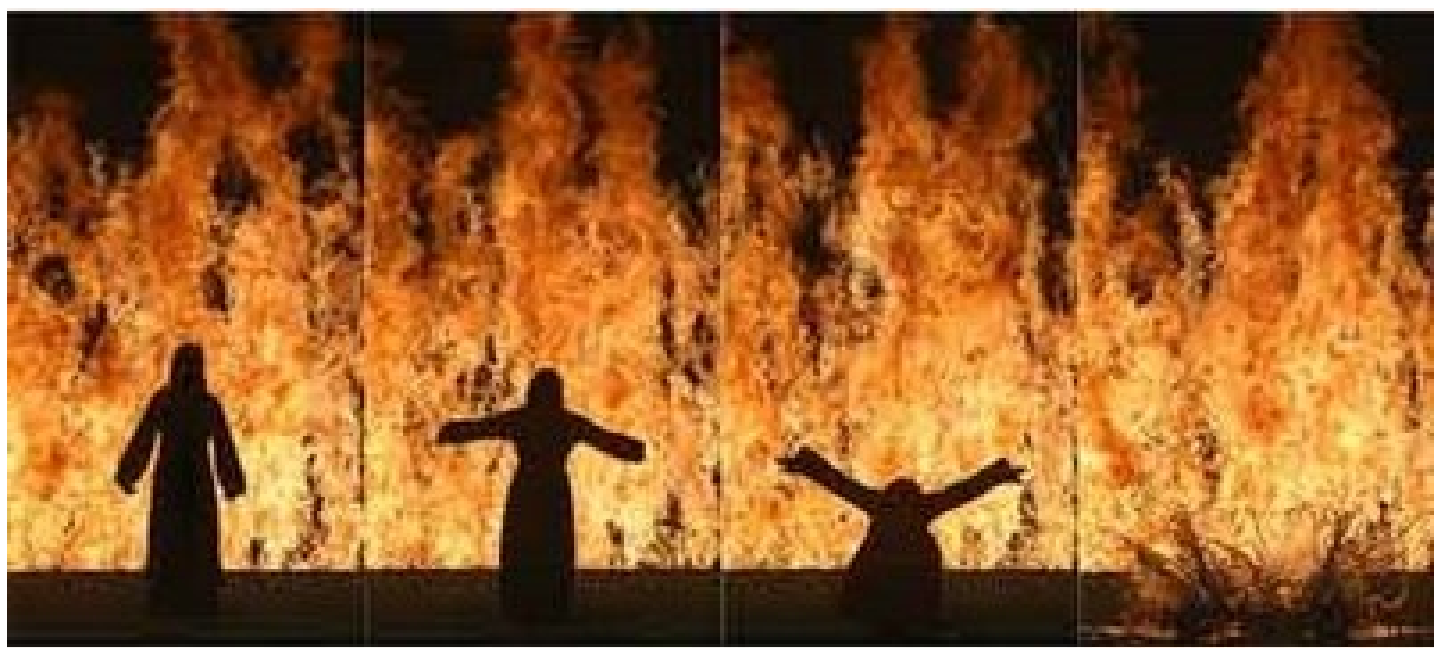

Fig. 23 Cena de Tristão e Isolda, dirigido por Peter Sellars com intervenção videográfica de Bill Violla

\subsection{Outras óperas}

O esgarçamento do uso do espaço em recursos tecnológicos nas artes cênicas tem ampliado e cruzado linguagens, numa orgia artística contemporânea. Cito a ópera 'Tristão e Isolda' (Fig.23), apresentada na Ópera Bastille em Paris, interpretadas respectivamente pelo tenor Clifton Forbis e pela soprano Waltraud Meier, em 2005, e 
dirigida por Peter Sellars, com cenografia/vídeo produzida pelo vídeo artista Bill Viola ${ }^{20}$.

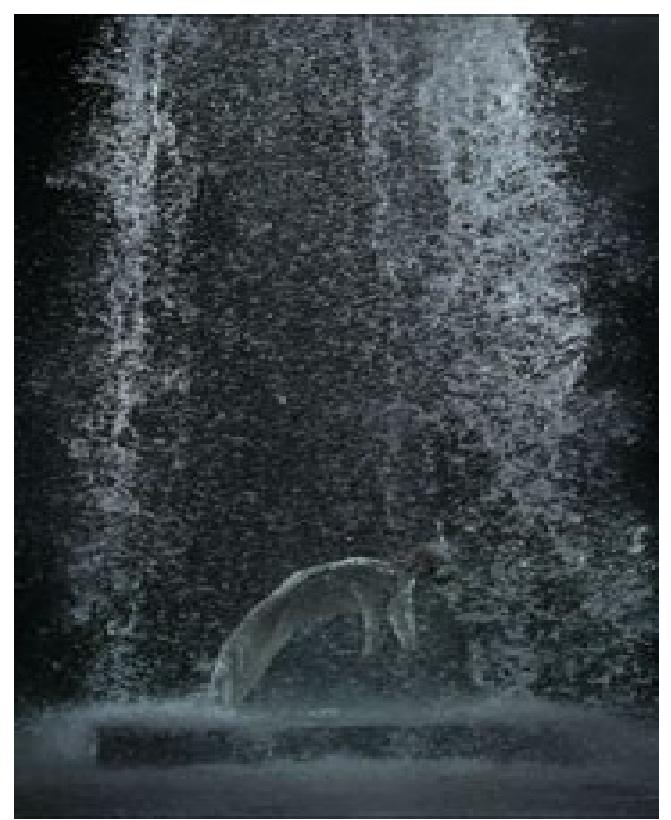

Fig. 24 Cena de 'Tristão e Isolda' dirigido por Peter Sellars com intervenção videográfica de Bill Violla

Neste trabalho, o cruzamento da grandiosidade da ópera de Richard Wagner soma-se à encenação de Sellars. Ao fundo um imenso telão com imagens de espaços que não necessariamente correspondem aos momentos e espaços da ópera, traduzem poesia ao trazer imagens de planícies, skyline de montanhas ao pôr do Sol, imagens de chuvas e tempestades (Fig.24). Os espaços ganham uma outra dimensão, já que o tempo de exposição dessas imagens é bastante alterado. Bill Viola, quando questionado pelo $\mathrm{L}^{\prime} E X P R E S S^{21}$ sobre a temática da monumental ópera wagneriana, observa:

\begin{abstract}
Wagner a créé là un véritable mythe. Dans notre vision de Tristan, il y a donc avant tout des êtres humains: les chanteurs sur la scène. Ils font face à la religion et à la nature. Ils ont un pied dans le monde réel, celui des passions et des déceptions, et un autre dans l'univers spirituel. C'est là qu'intervient mon film, projeté sur le fond de scène pendant les quatre heures que dure la représentation. Une tension naît de la confrontation constante entre ces deux mondes, une tension qui est l'essence même de la vie. Avec la vidéo, je souhaitais créer un monde d'images existant parallèlement à l'action
\end{abstract}

\footnotetext{
${ }^{20}$ Bill Viola é um videoartista Americano que começou sua carreira na década de 1970 com trabalhos no Everson Museum, em Syracuse - Nova York, influenciado por artistas como Nam June Paik, Bruce Nauman e Peter Campus. Seus trabalhos em vídeo consistem em instalações, vídeos e performances, sendo marcados por um uso transparente do aparato videográfico, um controle e entendimento complexo do tempo e por um inventivo uso do som.

${ }^{21}$ Periódico francês de grande circulação, com periodicidade semanal, versão impressa e digital
} 
scénique, un monde poétique pouvant servir de support à nos vies intérieures. ${ }^{22}$ (VIOLA, 2005)

O espaço é trazido no recurso do vídeo, porém como uma contribuição poética, transcendendo a figuração muitas vezes apontada por profissionais da área que considera o uso da tela projetada como a volta do telão pintado do século XIX. Ledo engano, pois com este exemplo temos a magnitude da tecnologia que se justapõe às melodias de Wagner, mas nunca as ilustram. Criam uma suspensão poética em que música, canto e imagem se fundem em algo difícil de mensurar.

\subsection{Novos formatos}

O coletivo de diretores de teatro alemão Rimini Protokoll, famoso por hibridizar muitas linguagens inusitadas em seus trabalhos, é responsável por um dos melhores exemplos do uso de vídeo para alterar as percepções de espaço, como o trabalho intitulado 'Cargo Sofia', do diretor suiço Stefan Kaegi, um dos pontas de lança dessa linha de investigação cênica que integra o coletivo Rimini Protokoll.

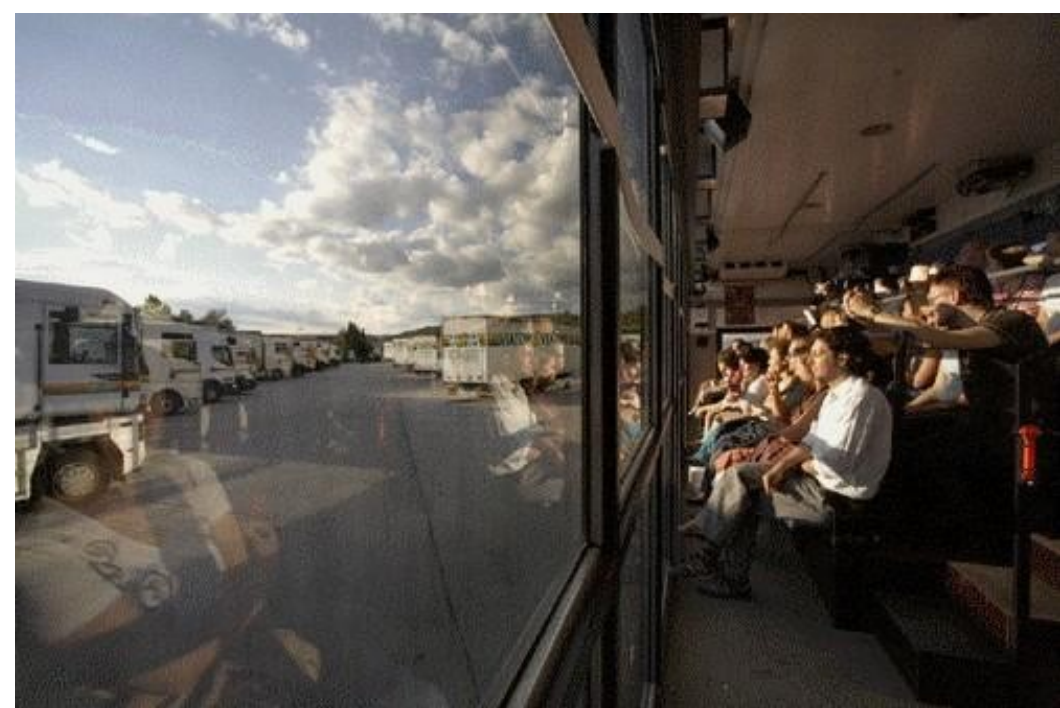

Fig. 25 Cargo Sofia - traseira de caminhão frigorífico adaptada para acomodação da plateia

\footnotetext{
22 Wagner criou um mito real. Em nossa visão de Tristan, então não está acima de todos os seres humanos: os cantores no palco. Eles enfrentam a religião e a natureza. Eles têm um pé no mundo real, das paixões e desapontamentos, e outro no universo espiritual. Este é o lugar do meu filme, projetado em pano de fundo durante as quatro horas que durem a representação. A tensão surge do confronto constante entre esses dois mundos, uma tensão que é a mesma essência da vida. Com o vídeo, eu queria criar um mundo de imagens paralelas à ação cênicaexistente, um mundo poético que pode servir de apoio às nossas vidas interiores.
} 
Kaegi encena nas mais diversas constelações peças de teatro documental, peças radiofônicas e encenações urbanas. Viajou durante vários anos com entusiastas do modelismo ferroviário suiços (Mnemopark) e, mais tarde em Cargo Sofia, adaptou a traseira de um caminhão frigorífico em plateia para embarcar espectadores numa viagem pela rotina de caminhoneiros que conhecem as estradas europeias (Fig. 25).

Uma das paredes do compartimento de carga virava uma vitrine envidraçada em que às vezes eram projetadas imagens dos motoristas na cabine e seus relatos de solidão e saudade de casa, com a reprodução interminável e repetida de centros de estocagem, hotéis de beira de estrada, postos de gasolina e lanchonetes fast food.

Existia uma visualização dos espaços por onde o caminhão passava e a plateia via e os reconhecia. Já em outras cenas, a vitrine, que é uma janela para o mundo, era rebaixada e telas escureciam a plateia sentada dentro do caminhão para projeção de outras imagens, algumas em tempo real, como as conversas da cabine do caminhoneiro (Fig. 26). A inserção do vídeo acontecia para desestabilizar a ideia de espacialidade que, em certos momentos é vista pela "janela", e em outros é virtualizada pelas projeções.

Outro coletivo (britanico-alemão) que trabalha com a questão espacial deslocada através dos recursos da projeção de vídeo é o Gob Squad, que assimila elementos da cultura do entretenimento, o que traz humor, drama e reflexão espontaneamente orquestrados a seus trabalhos.

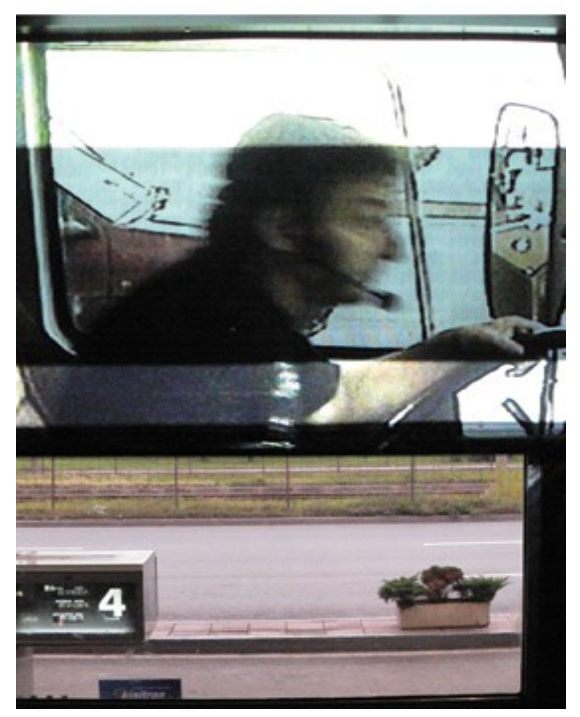

Fig. 26 Cargo Sofia - traseira de caminhão frigorífico adaptada para acomodação da plateia 
Em obras como Super Night Shot, já apresentado em São Paulo e Rio de Janeiro, em 2006, o entretenimento vem da vida real e é apresentado simultaneamente sob diferentes pontos de vista, o que acaba gerando uma espécie de jam session de imagens. Simon Will, um dos coordenadores do grupo, afirma ter uma lista enorme de influências 'passando pela pop art e por videoclipes. Tudo vem desse encontro de um grupo de amigos interessados em cultura pop e tudo que ela promete'.

Um dos primeiros trabalhos, chamado House, como já sugere o título, tinha como foco a vida em um lar classe média. O público presente era convidado a acompanhar o desenvolvimento de atividades cotidianas dentro de uma casa, previamente preparada para a ocasião, onde em cada quarto ocorriam situações diferentes, com personagens distintos, que acabavam se interligando ao longo da encenação.

Na entrada do público não havia direcionamento nem instruções, promovendo o incentivo da escolha de que momento e em que quarto entrar, ressaltando o caráter livre que se tornaria a maior característica dos trabalhos do Gob Squad: mesmo com a estrutura do trabalho previamente estabelecida, o desenvolvimento da peça e o efeito que ela gera são completamente imprevisíveis e livres do controle por parte dos artistas. Mas foi com Super Night Shot (Fig. 27) que o grupo teve sua experiência com a espacialidade multiplicada, transmitindo entrevistas e improvisações de diferentes pontos da cidade para diferentes telas, entre elas paredes de edifícios em grandes ruas de São Paulo.

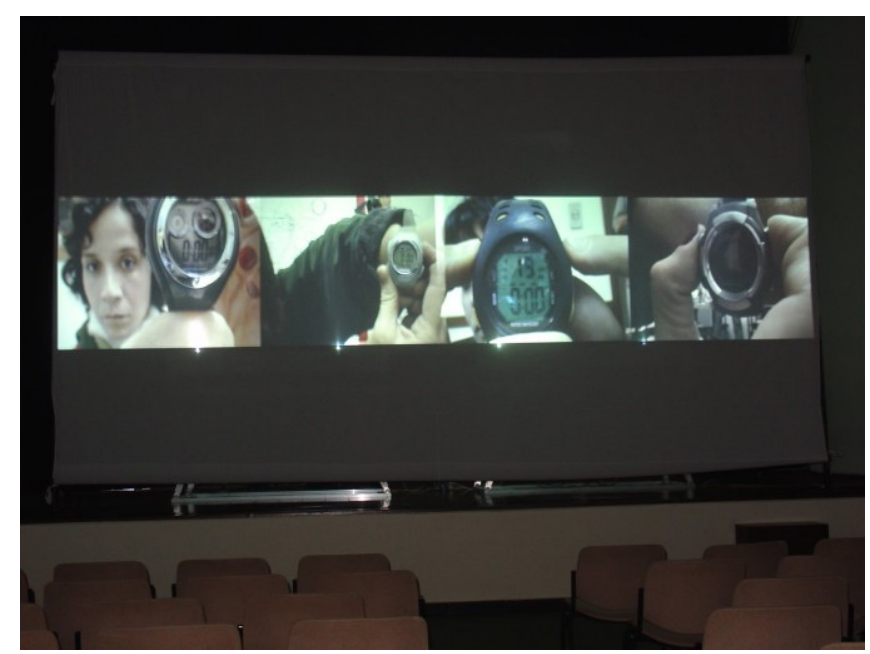

Fig.27 Cena do espaço de projeção de imagens para o trabalho Saturday Night Shot, do grupo Gob Squad 
O grupo brasileiro Recrutas, do Gob Squad, buscou viver os sonhos de pessoas anônimas que povoam a cidade transportando-as para o mundo do cinema e transformando a cidade em um set de filmagens para uma série de missões fantásticas. Bitucas de cigarro, pichações, carros e fachadas, tudo se transformou em adereço e cenário no filme-performance. Neste trabalho, transeuntes foram transforamdos em figurantes, amigos em potencial, amantes e até mesmo libertadores, por meio de quatro tomadas únicas com quatro câmeras.

Tudo era possível: presenciar uma ligação direta em um carro qualquer (com o consentimento de seu proprietário); acompanhar um beijo que se prolonga até a última parada de trem (com a anuência do parceiro escolhido ao acaso); ou a abdução dos protagonistas por alienígenas (devidamente paramentados).

Bem ou mal-sucedido em seus intentos, o grupo documenta o ocorrido, mostrando o regitro à plateia a partir de quatro pontos de vista distintos. Com todas as câmeras sincronizadas para as gravações nas ruas que circundam o local de apresentação, Super Night Shot era filmado por quatro performers, cada qual com sua câmera, uma hora antes de sua projeção para o público, sem qualquer corte ou edição (Fig. 28). Antes de tomar as ruas da cidade como cenário de suas aventuras, ocasião para encontros imprevistos entre indivíduos até então estranhos uns aos outros, os quatro performers declaram guerra ao anonimato.

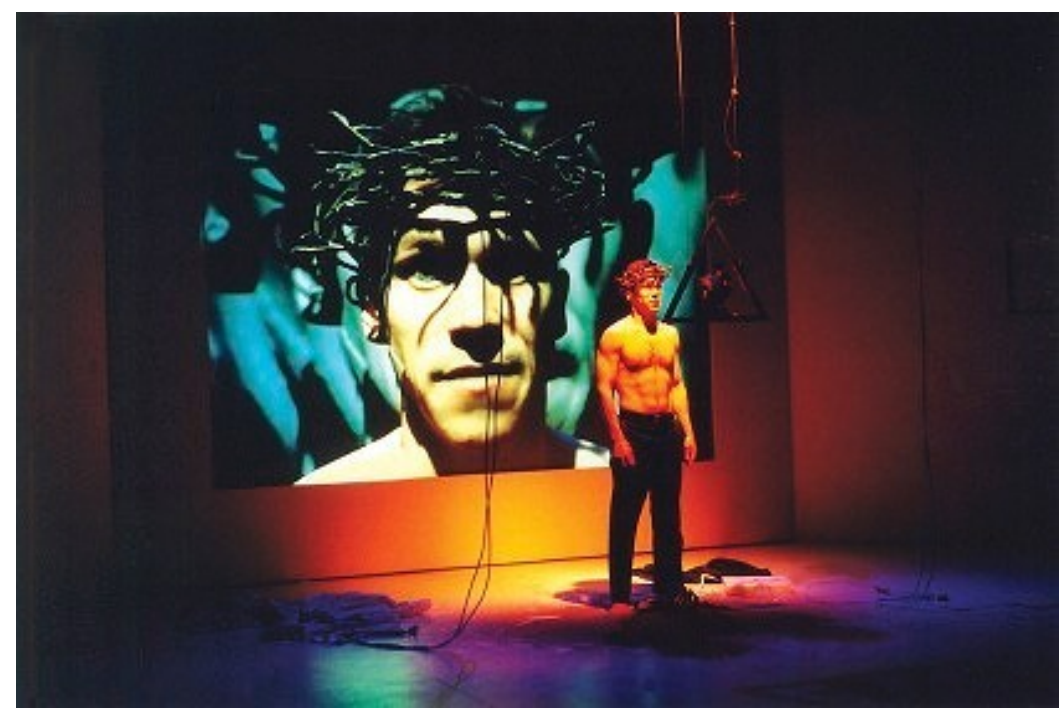

Fig. 28 Cena do espaço de projeção de imagens para o trabalho Saturday Night Shot

Um beijo hollywoodiano entre um auto proclamado herói e sua, antes insuspeitada, co-estrela, sinaliza a reunião final dos quatro exploradores, que voltam 
ao ponto inicial das gravações para serem recebidos pelo público que aguarda a projeção. As fitas são imediatamente projetadas lado a lado, de forma sincronizada, convertendo-se em uma epopeia em tela grande:

um espetáculo de vídeo projetado em quatro telas e filmado uma hora antes da chegada do público, produzido com quatro câmeras por quatro performes sem cortes ou edição. A aparente escolha aleatória dos 'atores', seleção por meio de sites da internet, realça o caráter aleatório da escolha das pessoas do espaço urbano com os quais os 'atores' interagem durante a ação. A cidade como cenário foi então traduzida para o palco vazio do Teatro Nelson Rodrigues (na cidade do Rio de Janeiro), através da projeção de vídeo com as imagens e fatos capturados. A interferência realizada no espaço urbano projetou-se no espaço tradicional do teatro. A projeção de filmes introduzida no teatro por Erwin Piscator, encontrou mais um novo contexto, fazendo-nos lembrar do trabalho de J. Svoboda que fez o filme um indispensável companheiro do ator entre a imagem e a realidade. (BERGHAUS, 2007, p.236)

Com a junção performática de Super Night Shot, Thierry de Luxe ${ }^{23}$ defende terse 'iniciado a Arte Minimal, o espaço teatral, o espaço urbano, a montagem e exibição das imagens como uma mistura entre o cinema e a vídeo-arte, a colagem musical dos $D j^{\prime} s^{\prime}$. Nossa atenção desloca-se então do produto final para o seu processo de feitura e para a presença do homem no espaço urbano.

Não posso deixar de citar o artista Nam June Paik que permite observar o caráter híbrido de seu método utilizado para chegar ao espectador por intermédio das experiências de interferência no espaço urbano. O espectador é levado a refletir sobre o tempo e o espaço com o vídeo, presente desde o início, documentando o tempo imanente do espaço urbano, enquanto o tempo cronológico é constantemente afirmado e exposto.

A exibição simultânea das ações, dos quatro agentes, cadenciados por $D j$ 's, é um exemplo de processo de aniquilação do espaço por meio do tempo que sempre esteve no centro da dinâmica capitalista. Porém ao assistirmos a colagem de imagens, sons e musicas, à presentificação, sem julgamentos de gosto, desconfiamos que estamos diante de um novo modo de ser sensível ao tempo-espaço, assim como um recorte dos tempos e dos espaços, do visível e do invisível, da palavra e do ruído que define ao mesmo tempo o lugar e o que esta em jogo na política como forma de experiência. A política ocupa-se do que se vê e do que se pode dizer sobre o que é visto, de quem tem competência para ver e qualidade para dizer, das propriedades do espaço e dos possíveis do tempo. (RANCIERE, 2005, p.16)

\footnotetext{
${ }^{23}$ Crítico de arte contemporânea, professor e historiador belga, nascido em 1944
} 
As questões entre teatro-arte-performance e espaços urbanos tem sido cada vez mais frequentes em festivais, mostras e literatura sobre arte em geral. A discussão entre os limites e a poética dos espaços da metrópole tem sido também uma das metas do último trabalho do artista Doug Aitken, cujo vídeo-instalação Black Mirror (Espelho Negro) explora a deslocalização e a alienação das pessoas em incessante movimento (Fig.29). A performance/instalação foi revestida com espelhos negros que refletiam infinitamente o horripilante vídeo de Aitken.

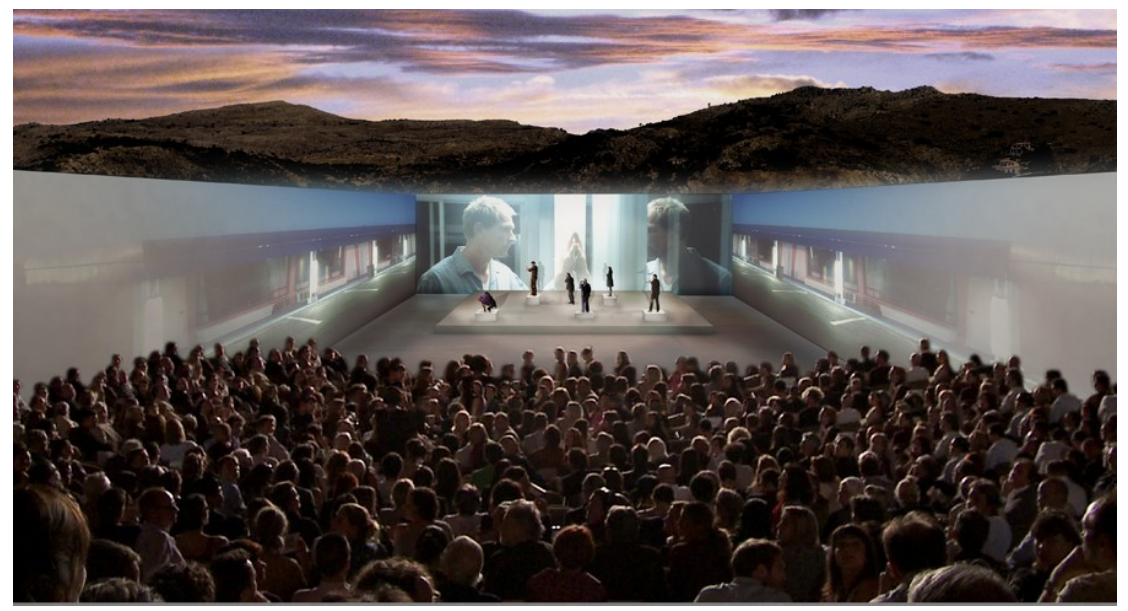

Fig. 29 Plateia em vídeo instalação Black Mirror

Gravado em três continentes, ao longo de um ano e meio, o vídeo usado em Mirror tenta fundir topografias da Nicarágua, de Hong Kong, do sudoeste dos EUA e da Grécia em uma paisagem ficcional perfeita. Sevigny afirmar gostar 'da ideia de pegar todas essas gravações de diferentes partes do mundo e comprimi-las para que tudo convirja num único espaço (...) quando você esta dentro do espaço, pode estar em qualquer lugar do mundo'.

Efeito parecido percebe-se em coletivos urbanos espalhados por grandes cidades do mundo, que criam performances de VJs e projetam vídeos artísticos sobre prédios, aproveitando as imensas e brancas paredes laterias de edifícios sem janelas, possibilitando assim um jogo poético de resignificação da paisagem urbana.

Aproveito para citar o trabalho dos holandeses Robbie Cornelissen, Peter Van Der, Rosa Menkman e Romy Tielman, que criaram projeções para o evento Virada Cultural, em São Paulo, no ano de 2010, com trabalhos que envolvem desenhos abstratos, personagens, animais, cenas de cotidiano e cinema. 
Com a utilização de recursos mais potentes de projeção, performances consistem em um método que mapeia elementos tridimensionais de um local e os reutiliza na hora da exibição de dados em planos bidimensionais, ou seja, todos os elementos como profundidade, altura e volume são relevantes na hora de se projetar algo em um plano, tornando tais elementos parte dessa projeção.

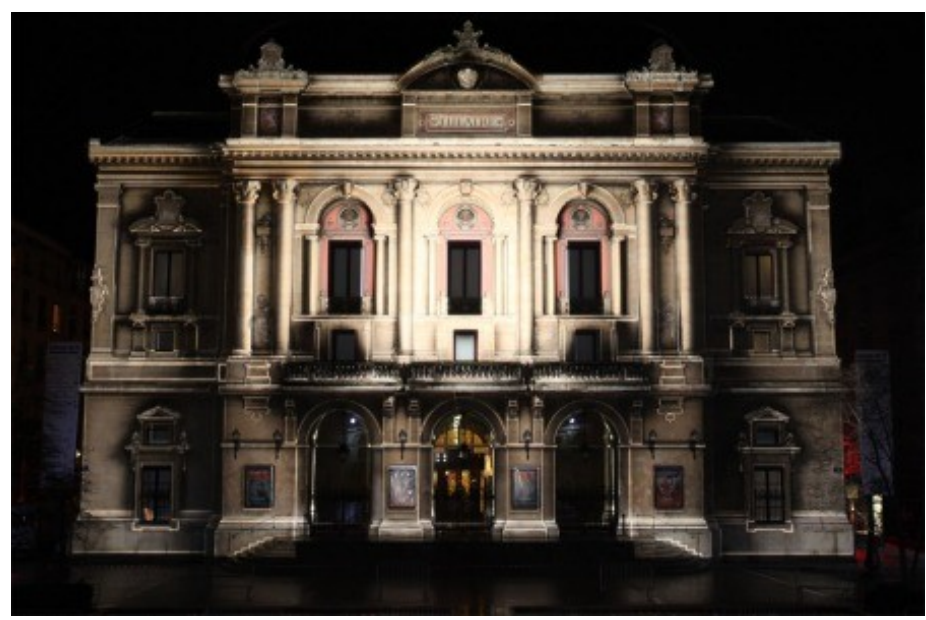

Fig. 30 Imagens de Video Mapping, realizado na cidade de Lion - França, pelo artista François Wunschel

A partir deste princípio, surge o Video Mapping (Fig. 30, 31 e 32), uma técnica complexa utilizada com a projeção em 3D, que faz o mapeamento tridimensional de todos os detalhes da faixada de um prédio, que podem ser utilizados para a exibição de vídeos e imagens, interagindo assim com arquitetura, criando portanto efeitos visuais incríveis. Por vezes, essas performances contam com músicas ao vivo e sempre, como base, transmutando espaços, edificações são transformadas como personagens cênicos que se desdobram, derretem e se modificam de forma espantosa.

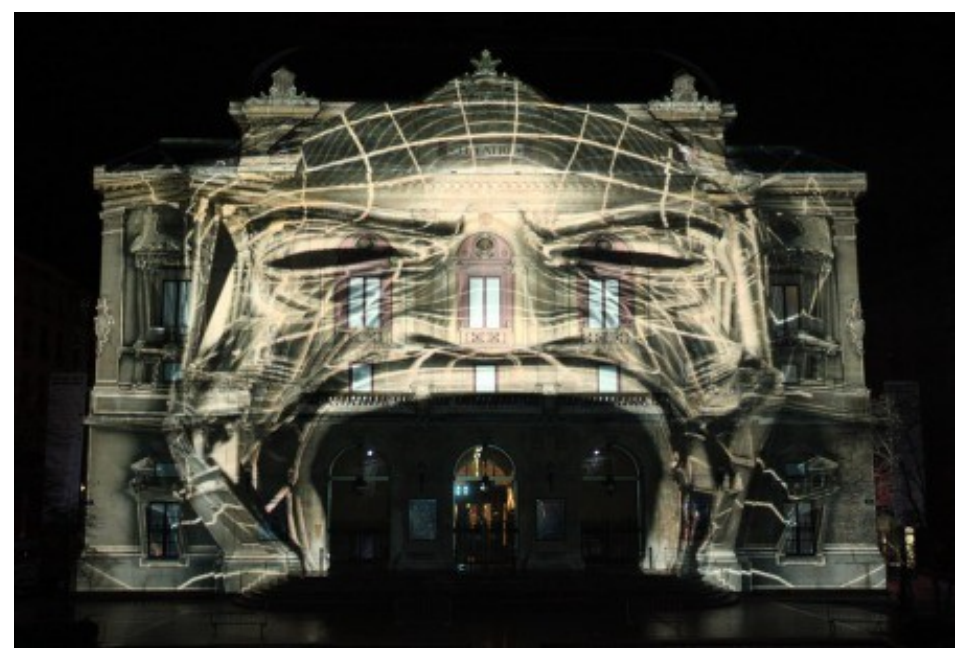

Fig. 31 Imagens de Video Mapping, realizado na cidade de Lion - França, pelo artista François Wunschel 


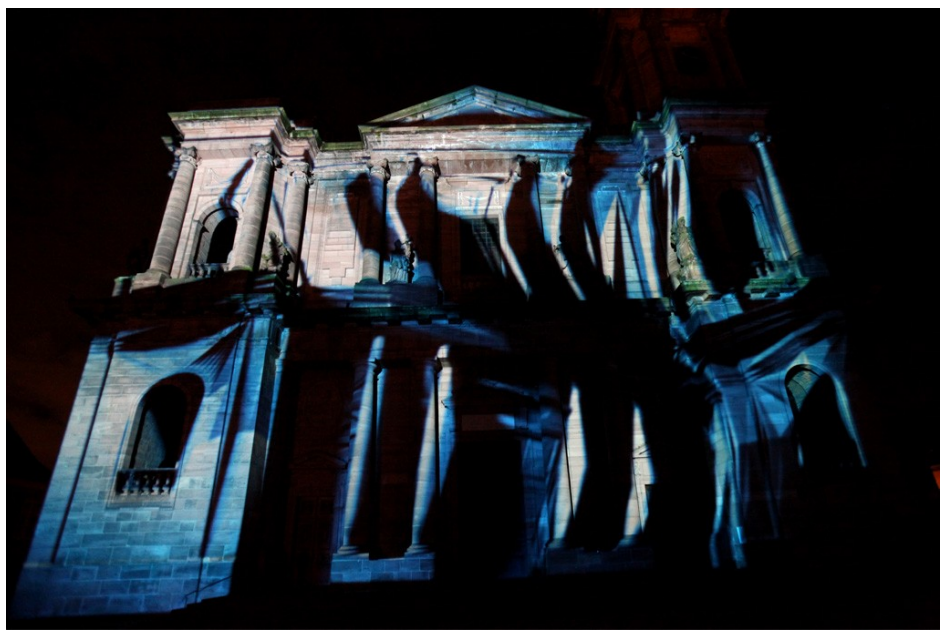

Fig. 32 Imagens de Video Mapping, realizado na cidade de Lion - França, pelo artista François Wunschel

Normalmente, como técnica utilizada para o entretenimento ou ferramenta publicitária, com base na topografia, as imagens não se limitam mais as duas dimensões de uma tela. Considerado o futuro da projeção, o Video Mapping (mapeamento de vídeo ou projeção mapeada) configura-se como uma fantástica técnica de vídeo que permite utilizar qualquer arquitetura como uma grande tela para projeção, se encaixando perfeitamente em cada aresta, em cada janela, degrau ou onde mais o artista quiser mapear.

Além disso, o mapeamento de vídeo é capaz de captar o áudio do ambiente e interagir com as imagens de maneira orgânica. A técnica pode ser gerenciada por uma pessoa ou configurada para funcionar automaticamente criando novas realidades. Qualquer superfície pode ser mapeada; o processo se baseia em projetar uma imagem numa superfície e através de um software, processar o mapeamento dos pontos que cobrem alguns de seus detalhes, como arestas, colunas, portas e janelas.

Com isso podem ser projetadas imagens independentes nessas áreas que quando combinadas, criam ilusões e encontram aplicações tão distintas que vão desde o marketing mais explícito de marcas e novos produtos, até festivais de música, pistas de clubs e vídeo-performances.

Acredito que o recurso será rapidamente incorporado em cenografias de shows e peças teatrais, uma vez que está sendo difundido também em instalações e em eventos híbridos com teatro, performance e dança. 


\subsection{Novos formatos - No Brasil}

Dentre as produções nacionais, destaco as experiências do grupo paulistano Phila7, que mantém um sistemático empenho na pesquisa de projeções de imagens em seus trabalhos teatrais e performativos. Aponto também, qualitativamente, 0 trabalho Uzina-Uzona, do Grupo Oficina, que tem intensificado o uso de captação de imagem e projeções por todo espaço onde se apresentam.

Nas encenações de José Celso, em especial na série épica 'Os Sertões', podemos conferir uma riqueza muito grande de possibilidades do uso de imagens previamente gravadas e a transmissão ao vivo, captadas por varias câmeras operadas junto aos atores, criando conjunções entre os ambientes e os espaços da obra de Euclides da Cunha, que se desdobram em imagens projetadas contemporâneas, dando um novo significado poético ao espaço.

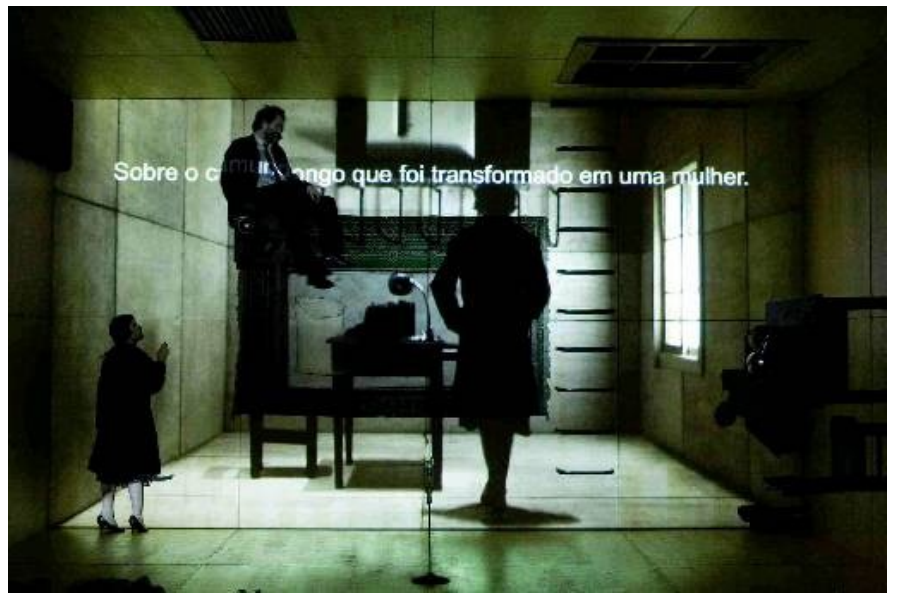

Fig. 33 Cena de Não sobre o amor, com cenografia de Daniela Thomaz

Por exemplo, ao citar as belezas da flora brasileira com detalhes e cores, o que se vê no vídeos são carros alegóricos do carnaval do Rio de Janeiro, ou mesmo quando se fala em cena sobre as características dos tipos de solo e terra do Brasil, as projeções revelam texturas de peles e pelos em detalhes, close ups rápidos que só fazem o textopalavra cruzar com a imagem tecnológica.

Vencedora do Prêmio Shell do Rio de Janeiro nas categorias cenografia e iluminação, 'Não sobre o amor' (Fig.33) faz parte dos projetos premiados do trio Felipe Hirsch (direção), Daniela Thomas (cenário) e Beto Bruel (iluminação), da Sutil Companhia de Teatro. $\mathrm{O}$ tema era o amor, neste caso, materializado nas cartas entre o 
teórico russo Victor Shklovsky e a romancista franco-russa Elsa Triolet, reunidas em livro homônimo.
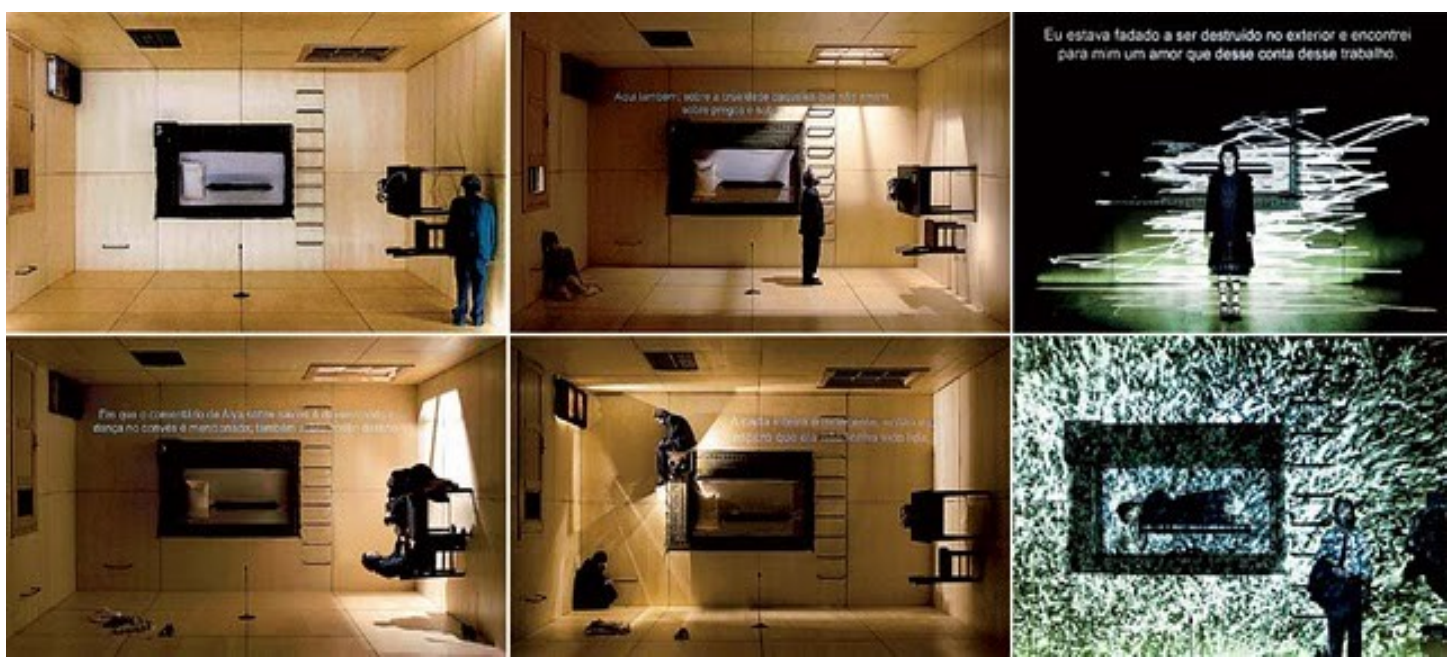

Fig. 34 Trechos de Não sobre o amor com variações cenográficas de Daniela Thomaz

A cena apresentava-se como uma caixa de madeira, intimista, aberta para o público. O conceito do cenário foi o da síntese com poucos elementos: uma cama com uma mesa de cabeceira, presas no fechamento de fundo da caixa; uma porta construída numa das paredes laterais; na outra um conjunto escrivaninha/máquina de escrever/cadeira; e, no teto uma janela e o duto de calefação (Fig. 34).

O desafio lançado aos atores pela cenógrafa e pelo diretor foi o enfrentamento da gravidade. Para a ocupação do espaço cênico pelos personagens foram necessários aparatos como uma escada do tipo marinheiro e painéis de madeira perpendiculares às paredes da caixa. Para o iluminador restaram apenas três entradas de luz - a porta, a janela e a borda frontal da caixa -, que enfocam os atores em momentos específicos, por vezes simulando a iluminação diurna e, por vezes, interagindo com projeções textuais e visuais que complementam o cenário. Tentei acompanhar o claro/escuro da Daniela. (BRUEL, 2009. P. 352)

O cenário de Daniela Thomas é decisivo na transcrição deste estado de suspensão, ao subverter os planos espaciais criando uma área de evasão, na qual as projeções de imagens estão plenamente integradas à mudança do eixo gravitacional dos personagens. Ao ser questionada se, para sua atuação, o cinema cedeu lugar à cenografia, Daniela Thomaz responde:

Busco no teatro certo selo cinematográfico (...) isso vem do amor que tenho por essa linguagem (...) mas a cenografia está envolvida com o cinema, de qualquer forma. Minha grande descoberta como cenógrafa foi a questão das transparências, o uso do filó e de espelhos, que possibilitavam certos cortes em cena, ins- pirados na edição cinematográfica. No teatro, há uma 
limitação atávica: ao terminar uma cena, o ator tem de sair do palco. Podese apagar a luz, deixar tudo preto, mas isso limita o ritmo, o ator pode demorar a sair para a coxia. $O$ uso dos filós permitiu montar uma cena atrás deles, outra na frente. Podia-se cortar de uma cena para outra instantaneamente. Isso foi importante para Gerald, fazia parte de um processo em que ele estava trabalhando, a descontinuidade do ritmo, algo próprio do cinema que estávamos trazendo para o teatro. Atualmente, se olharmos fotos de meus trabalhos de cenografia em teatro, por exemplo em montagens dirigidas por Felipe Hirsch, elas parecem stills de cinema. Busco no teatro certo selo cinematográfico, uma gestalt de cinema, não sei explicar por quê. Isso vem do amor que tenho por essa linguagem, que é algo muito interiorizado, estou impregnada dessa paixão. É algo que me mobiliza desde menina e está em tudo o que faço. Mesmo o trabalho menos ligado ao cinema transpira esse sentimento. (...) Fui criada nesse universe em que tudo era possivel e acho que minha vida é resultado disso. A falta de fronteiras para minha criação é uma vantagem e uma enorme desvantagem. A falta da academia, dos títulos, dos diplomas, das setorizações me transformou nessa pessoa. O trabalho que faço me obriga a especializacões instantâneas. Por exemplo, eu e Felipe (Tassara, arquiteto, seu marido e sócio) faremos (a cenografia de) uma exposição sobre a arte espanhola do seculo XVI. Sou obrigada a conhecer isso. O hibridismo é da natureza de nosso tempo. Circulo nessa falta de fronteiras, nessa globalização da arte. (THOMAS, 2008, p.7)

Em Não Sobre o amor a cenografia cria um quarto desrespeitando as leis da gravidade, que serve de tela para projeções de vários ângulos do mesmo quarto prégravado, num claro jogo com os ângulos da fotografia cinematográfica. Um único espaço físico passa a ser multifacetado, incluindo projeções dos mesmos atores dialogando em partes do quarto em oposição aos atores reais em outro ponto.

Em minhas experiências como diretor e cenógrafo sempre busquei usar os recursos do vídeo. O primeiro deles se realizou com o objetivo de transfigurar o espaço cênico de uma antiga fábrica de cobertores (Cobertores Paraíba), na cidade de São José dos Campos, no interior de São Paulo.

Em experiência cênica com o meu grupo 'Teatro da Pomba-Gira' e outro grupo da cidade, 'ClA do Trailler', pesquisamos por meses o teatro performativo e questões de ritualidade. Por fim concebemos o trabalho intitulado 'Yulunga - Poema para um Deus morto' (2006), em que as paredes da antiga fábrica foram alvo de projeções em justaposição de signos e imagens que, às vezes, dialogava com a cena fazendo provocações de tons políticos.

Numa das cenas, um pênis cenográfico de seis metros de comprimento era içado das profundezas da fábrica e, num ritual com músicos ao vivo, eram projetadas 
neste grande falo imagens das torres do Worl Trade Center, em Nova York, minutos antes de serem atingidas pelo atentado terrorista de 2001 (Fig. 35).

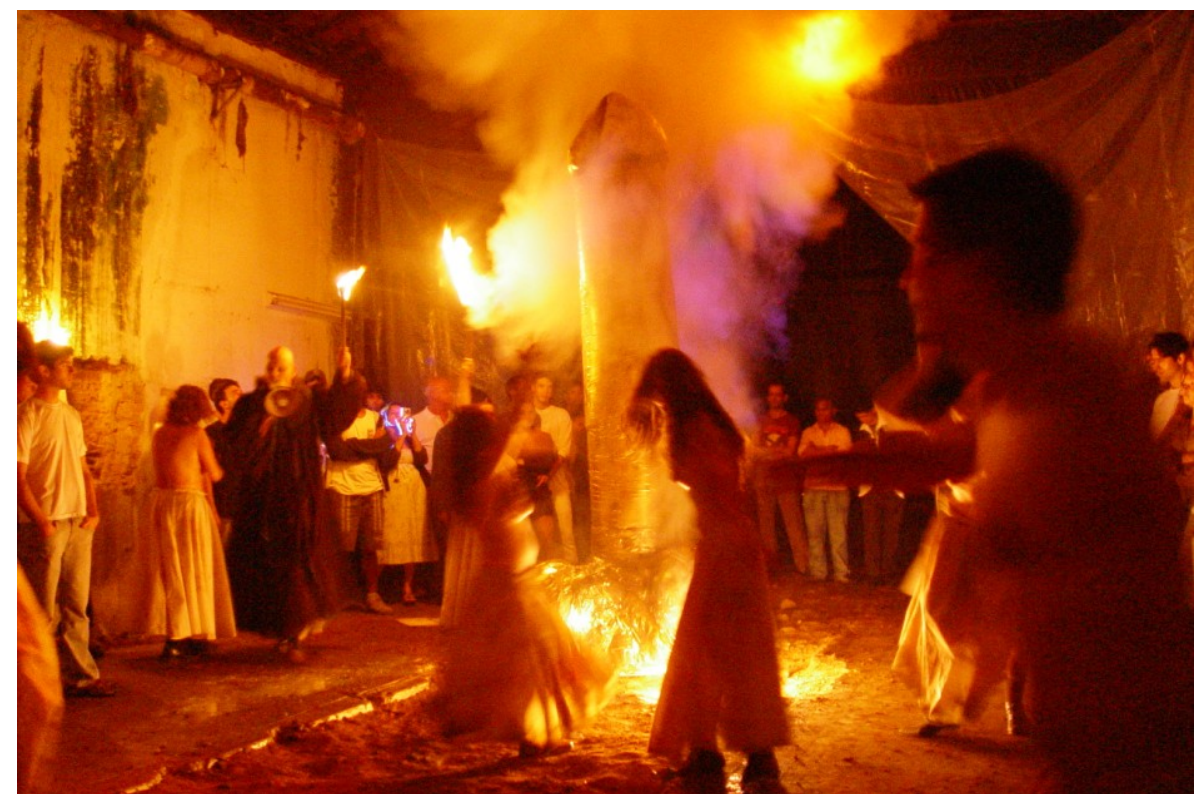

Fig. 35 Cenas de 'Yulunga - Poema para um Deus morto', realizado em 2006, na cidade de São José dos Campos, direção de Marcelo Denny

Em outra cena, o público tinha que andar pelo espaço e as projeções de imagens serviam para ocultar as reais características do espaço da fábrica, permitindo muitas possibilidades cênicas e sígnicas. A cena mais polêmica acontecia quando o público se deparava com vídeo, de minha autoria, projetado em uma parede, em que o close de olhos azuis se fundia a closes de um ânus soltando tinta azul (Fig. 36).

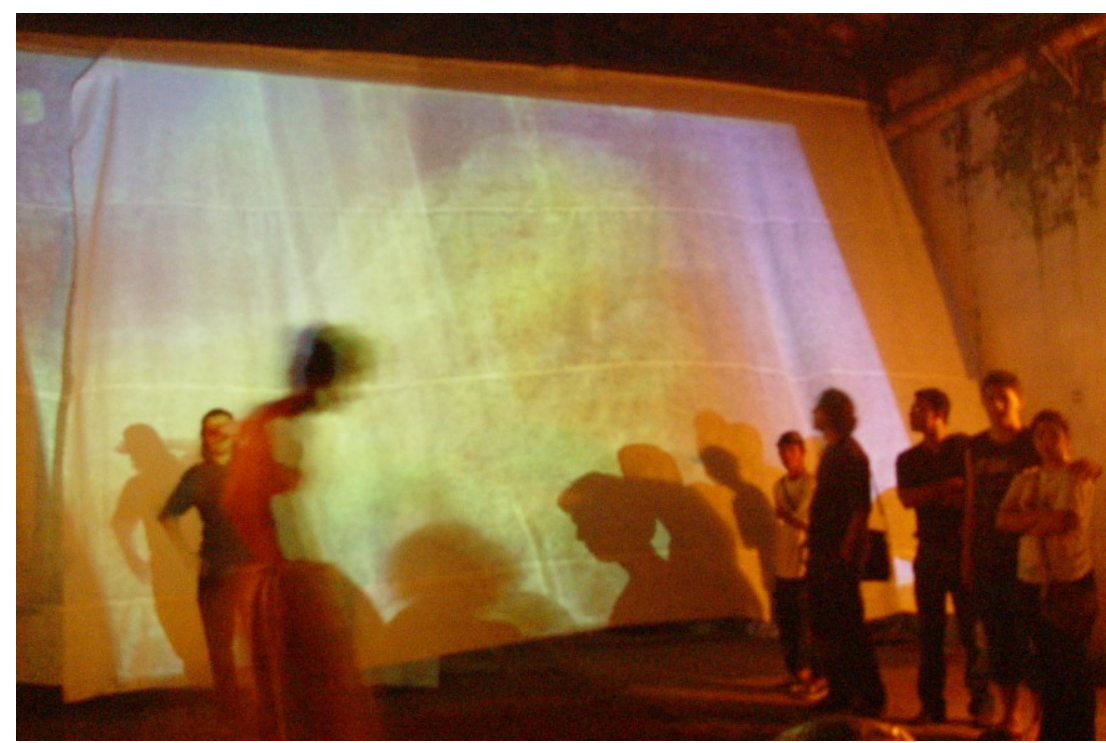

Fig. 36 Cenas de 'Yulunga - Poema para um Deus morto', realizado em 2006, na cidade de São José dos Campos, direção de Marcelo Denny 
O público demorava a perceber que não se tratava de uma simples parede da fábrica, mas de uma ânus gigante, de aproximadamente 9 metros por 11 metros, e adentrava dentro do 'ânus imagem' para outra cena. Percebo em meu trabalho o vídeo não só como uma possibilidade de recriar o espaço, mas também de causar um estranhamento no espaço, um espanto que leva a outros entendimentos, ao mesmo tempo que cria uma atmosfera lúdica, imersiva e até interativa com a imagem, já que o público atravessa o ânus imagem entrando na projeção.

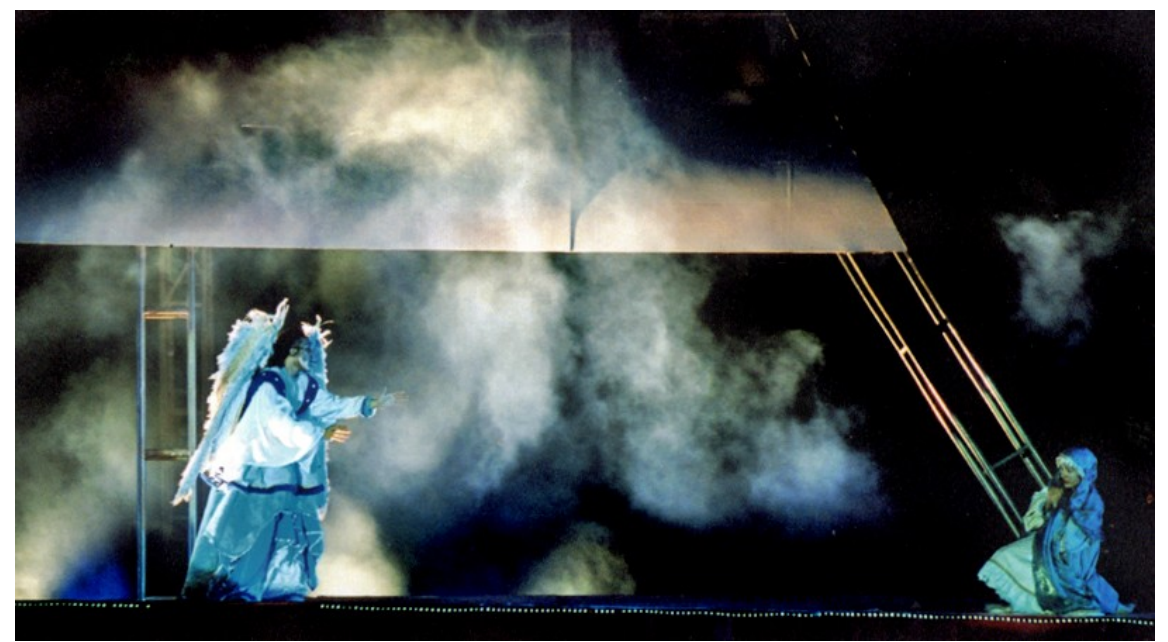

Fig. 37 Cena do "Auto de Natal”, direção de Marcos Bulhões, cenografia de Marcelo Denny. Acima, tela de projeções em forma triangular que dialogavam com imagens ao vivo, da encenação, e também com imagens previamente gravadas

Outro trabalho de minha autoria, relevante neste sentido, foi o espetáculo 'Auto de Natal' (Fig. 37), estreado em 2003, na cidade de Natal, em que utilizamos uma grande tela triangular sobre o palco, desdobrando a forma de uma vela de um barco (palco), em que eram projetadas imagens justapostas à encenação de Marcos Bulhões, que unia dança, grupos folclóricos e teatro.

A experiência mais intensa com tecnologia aconteceu no trabalho "Devorando Fausto" (direção de Marcos Bulhões), em 2008, e "Devorando Quixote" (direção em parceria com Márcio Pimentel), também de 2008. Em ambos os trabalhos, a questão do vídeo fletar com os desdobramentos do espaço era forte.

Em "Devorando Fausto" existia a transmissão direta de imagens ao vivo, sendo projetadas nas paredes brancas do espaço escolhido para a montagem: o Forte dos Reis Magos, em Natal, construção datada de 1598. Criando um efeito caleidoscópio, imagens de outras cenas em outros espaços eram multiplicadas em projeções, além de detalhes que eram ampliados e transmutados, como na cena em que um ator, 
personificado como Jesus Cristo corta com um bisturi seu peito. Câmeras gravavam em close up o escorrer do sangue e as imagens eram projetadas por toda torre e cúpula da capela interior do espaço, pintando-a de vermelho com a imagem do sangue.

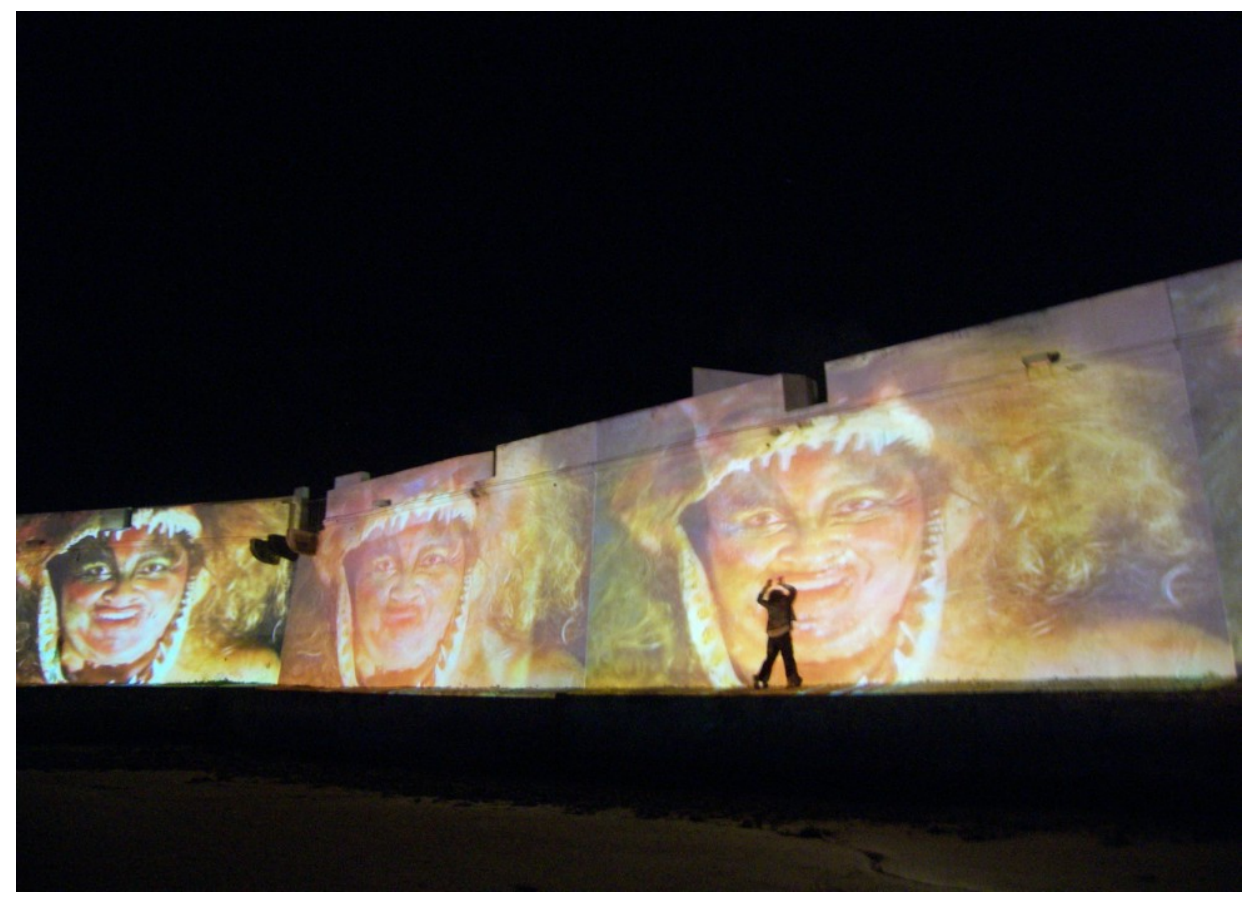

Fig. 38 Cena do personagem Mefistófeles projetado por vários projetores, simultaneamente, nos muros do Forte dos Reis Magos, em Natal, para o espetáculo “Devorando Fausto", em 2008, direção de Marcos Bulhões, direção de arte de Marcelo Denny

O espaço torna-se múltiplas telas e a todo momento se reconfigura com imagens sofisticadas sobre paredes de quase 500 anos. Toda a muralha que reveste 0 Forte dos Reis Magos foi aproveitada, e a imagem de um universo era projetada nela criando uma tela feita por várias projeções, atingindo aproximadamente mais de 30 metros, revestindo as brancas muralhas, inclusive com close up do personagem Mefistófeles (Fig.36). Ou seja, a muralha branca era transformada com som e edição cinematográfica, com a utilização imagens tecnológicas, era que abriam fissuras poéticas e diálogos entre a imagem e o suporte/tela, uma importante construção que deu origem à cidade de Natal.

Com recursos da UFRN - Universidade Federal do Rio Grande do Norte, utilizamos mais de dez projetores de alta potência (até 10.000 LanceLumens) envolvendo e cobrindo de imagens toda a volta dessa fortaleza, que é pintada de branco e transforma-se em um grande tela. A direção dessas imagens, bem como sua costura na dramaturgia, ficou a cargo do diretor Marcos Bulhões. 
Sobre a direção de arte e tecnologia como redescoberta do espaço histórico tenho a dizer que é impossível ficar imune à beleza do Forte dos Reis Magos invadido por dezenas de artistas que recriaram a arquitetura e a funcionalidade espacial. A sua escolha forçou os criadores a entender as relações espaciais para além do teatro tradicional, como um verdadeiro set cinematográfico, num diálogo entre as potencialidades de cada metro quadrado.

Um vetor da visualidade dessa cenografia é a instalação, arte conceitual que pretende a construção de sentido da obra a partir do uso do espaço como suporte. Aqui o espaço ultrapassa a sua condição geográfica: salas de pedra, escadarias, portas, capela, casa de pólvora, mirantes, lagoas e mangues, revelam-se espelho do inconsciente e transgressão.

O roteiro utiliza as potencialidades de uma construção do século XVI para criar metáforas espaciais contemporâneas (tela de cinema, navio surreal, palanque, laboratório, parque de diversões bizarro, castelos oníricos, cabaret) resultando em imagens fortes como quando o público contempla, do alto da muralha, bailarinos dançando na areia da praia, com a cidade de Natal ao fundo, incluindo a ponte e um retumbante skyline do mar emoldurando a cena.

Para a arte contemporânea o corpo é matéria-prima fundamental. O corpo foi outro elemento que a encenação privilegiou, com a abordagem do corpo liberto, quando propus uma radicalização desse enfoque defendendo a ideia de potencializar as dinâmicas do uso do corpo pintado, sujo, iluminado, projetado e até multilado.

A tônica na body art perpassa todo o evento: o corpo frente à tecnologia das projeções de imagens, das pinturas ritualísticas, o corpo nu, ampliado, o corpo como tela, subvertendo a própria ideia de caracterização. Destaco a interação com a tecnologia como marca preponderante desta obra devido às projeções em vídeo que pintaram e transformaram o Forte em múltiplos espaços, remodelando a arquitetura histórica com novas imagens, numa interação com o espaço-tempo e também com o real e o virtual.

A tecnologia reforça o hibridismo da montagem através da transmissão ao vivo de imagens e sentidos, num caleidoscópio simultâneo entre o real e o virtual, poesia multimídia, com novas possibilidades da tecnologia digital como suporte estético da 
cena, vestindo o espaço com imagens, despindo-o de seu sentido meramente histórico. Trânsito livre de signos: re-significar é re-poetizar.

Acredito que belas e fortes imagens ficaram guardadas na mente do público, provocando um subversivo sentido de memória com um dos marcos principais da formação da cidade. Em nossa rede de criadores acreditamos na desordem artística, na radicalidade como passe-livre às nossas guerras necessárias, como estímulo para refletirmos nossas idiossincrasias fáusticas. Em 'Devorando Fausto' canabalizamos obras, imagens e sentidos e regurgitamos nosso sagrado grito.

A influência da mistura entre arte, tecnologia e prática social na vida urbana e seus espaços é uma das correntes mais fortes dentro do cenário e atribuições das artes de forma geral na contemporaneidade. É natural que cada vez mais as performances somem ao público os espaços e os artistas, que se reúnem para explorar o espaço urbano e a integração de novas tecnologias e ideias originais à comunicação entre pessoas.

Processo possível por meio das criações sonoras experimentais e atuações audiovisuais sob a forma de reuniões entre interessados nos campos da arte, tecnologia, música experimental, arte sonora, dispositivos interativos e processos de áudio e vídeo em tempo real. Esses encontros surgem para oferecer uma nova ideia de espaço físico, ajudando o público a decifrar, de forma artística e até onírica, o que está oculto nas produções aos espaços cotidianos.

\subsection{Espaços impossíveis}

Para finalizar, proponho que por meio da tecnologia, com a presença de novas imagens advindas da cinematografia e a da videografia, podemos obter novas relações de espaço na cena contemporânea, para além da ideia de cenografia ou de ilustração de um espaço (como na tradição dos telões pintados do século XIX).

As novas telas (sejam em projeções ou em LEDs) nos transportam à relação sígnica, e até corpórea, com a sobreposição de espaços e a criação de fricções entre o espaço "aqui e agora" e os espaços inconscientes, abstratos (como na tradição da dança com a vídeo-linguagem), em que notamos uma experimentação maior do uso da 
imagem tecnológica na criação de espaços com imagens, cores e texturas, muitas vezes abstratas.

Na tradição do cinema experimental e de animação que Gilles Deleuze define em sua obra 'A Imagem - Movimento', aborda-se a ideia de espacialidade nas imagens cinematográficas, explorando as possibilidades de sombra, formas e abstrações

\begin{abstract}
Como construir um espaço qualquer (em estúdio ou exteriores)? Como extrair um espaço qualquer de um estado de coisas dado, de um espaço determinado? O primeiro recurso foi a sombra, as sombras: um espaço repleto de sombras, ou coberto de sombras, torna-se espaço qualquer. Vimos como é que o expressionismo opera com trevas e a luz, com o fundo negro opaco e o principio luminoso: os dois poderes acoplam-se, abraçamse como lutadores, e não ao espaço uma forte profundidade e uma perspectiva acusada e dformada que vão ser preenchidas por sombras, ou na forma de todos os graus do claro-escuro ou na forma das estrias alternantes e contrastadas. Mundo "gótico", que afoga ou quebra os contornos, que dota as coisas de uma vida nao-organica onde elas perdem a individualidade, e que potencializa o espaço, fazdendo dele qualquer coisa de ilimitado. A profundidade é o lugar da luta, que por vezes atrai o espaço para o sem-fundo de um buraco negro e outras vezes o puxa para a luz. (DELEUZE, 2004, P. 172)
\end{abstract}

A imagem tecnológica abstrata, advindo dos pressupostos da arte abstrata ${ }^{24}$, seria a que não se prende à representação da realidade tangível, em que não há reprodução ou representação de imagens do mundo visível.

Recomendo atenção para não confundir o mero distanciamento das aparências com a criação de arte sem nenhuma conexão com o mundo visível. Distanciamento das aparências já era uma forte tendência em muitos dos principais movimentos artísticos modernos no início do século XX, entre eles o Fauvismo, o Expressionismo, o Cubismo e o Futurismo.

Algumas obras desses movimentos chegaram a distanciar-se de tal forma da aparência natural das coisas que elas tornavam-se praticamente irreconhecíveis. Porém, ainda assim, continuavam sendo obras que representavam algo visível. $\mathrm{Na}$ arte tecnológica abstrata, ao contrário, o artista se expressa por intermédio de formas, cores, texturas e ritmo, inteiramente livres de qualquer influência de objetos da realidade. Não há uma tentativa de representar a imagem de nada.

\footnotetext{
${ }^{24} \mathrm{O}$ início do movimento abstrato é geralmente atribuído a Wassily Kandinsky, que por volta de 1910 passou a pintar quadros puramente abstratos, mas houve outros artistas que adotaram esse rumo, entre eles Robert Delaunay, Kazimir Malevich e Vladimir Tatlin
} 
Recursos de apontamentos com imagens abstratas e líricas podem e devem criar espaços não reais e novos. Imagens ruidosas, típicas de restos de edição, telas brancas, formas geométricas ou orgânicas projetadas, podem representar espaços do porvir ou nuances espaciais mais poéticas que introjetam o atuante (ao vivo) num espaço amplo de significados, repleto de significantes de cores, texturas e ritmo. 0 processo pode ser completamente associado a esquemas mais subjetivos de leituras, como notamos em muitas produções cinematográficas desde a década de 30 até a atualidade, como as vídeo instalações e a WEB art.

\footnotetext{
O cinema abstrato toma vida em torno dos signos, e graças a eles, segue sendo um dos gêneros que mais custa ser compreendido pelo público em geral, pelo simples fato que sua forma não é somente figurativa. Se trata de uma antítese absoluta ao cinema narrativo comercial. De outra maneira, também pode ser um dos subgêneros mais ricos, o mais sofisticados do cinema experimental. (DUNCAN, 2009, p.51)
}

Ao final do filme '2001 Uma odisseia no espaço', o diretor Stanley Kubrick e sua esposa, que era artista plástica, jogaram em aquários, de forma experimental, óleos, tintas e outros fluidos sobre plataforma de luz para criar formas abstratas orgânicas para apontar os confins do universo. Essas imagens abstratas, coloridas e maleáveis, ainda hoje impressionam como efeitos especiais e, ao mesmo tempo, nos remetem a formas orgânicas (células, sangue, esperma, urina) que muito se parecem com o interior de nosso organismo.

Os confins do universo para Kubrick são muito parecidos com o interior orgânico humano, ao mesmo tempo que não são, pois o artista aponta, em diversas sequências, para uma abstração total, um flerte inédito no cinema, quando aposta em longas sequências de abstração cromática, semelhantes ao que Wassily Kandinsky propôs em suas telas.

Vemos aqui a inclusão da ideia de um lugar, de um espaço, em que não nos reconhecemos, mas aceitamos como lugar e espaço. A experiência fenomenológica do sujeito individual não coincide mais com o lugar onde ela se dá. As coordenadas estruturais não são mais acessíveis à experiência imediata do vivido e, em geral, nem conceituadas pelas pessoas.

Dá-se um colapso da experiência, pressuposto das intervenções artísticas que visam um reordenamento do espaço e da sua apreensão pelo observador. Nas artes, 
hoje, têm-se sujeitos individuais inseridos em um conjunto multidimensional de realidades radicalmente descontínuas, espaços abstratos, homogêneos e fragmentários.

O espaço urbano perdeu situabilidade, uma inscrição precisa em dimensões geográficas, acessíveis à experiência individual; instaura-se um problema de incomensurabilidade entre o real e o não real. Em muitos casos, a cenografia tem o dever de tornar impossível sua representação, adotando aquilo que a imagem fotográfica, por mais abrangente que seja, não dá conta, incorporando as dimensões mais abstratas dos espaços.

A preocupação com a espacialidade nas imagens tecnológicas é superior ao do posicionamento do espectador ou do atuante neste sistema global complexo. É também uma questão de representabilidade: embora afetados no cotidiano pelos espaços nao-reais, não temos como modelá-los mentalmente, ainda que de forma abstrata. Ocorre uma ruptura radical entre a experiência cotidiana e esses modelos de espaços abstratos.

Nesse sentido, e num viés mais contemporâneo, altero o sentido da palavra espaço para local, partilhando assim a posição do arquiteto japonês Arakawa e a de Gins, ao descreverem como o corpo se associa ao espaço de modo que 'o corpo é sempre um corpo no espaço'. Ou seja, um corpo espacializado, e por necessidade um corpo arquitetônico. A percepção desse corpo através da imagem tecnológica (inclusão de imagens da WEB) pode dividir-se em três categorias diferentes, a partir de como o corpo e a imagem se associam ao espaço:

- Espaço de convergência do perceptual, em que são registradas as qualidades do aqui e do ali;

- Espaço de convergências do imaginário, em que são preenchidas as brechas existentes na captação perceptiva;

- Espaço de convergência arquitetônica, em que é conferida uma situação de oposição entre elementos híbridos por serem parte perceptuais, parte imaginários.

A dança tem se utilizado mais dos recursos da abstração do que qualquer outra arte cênica, visto que comumente percebemos o uso de imagens abstratas em espetáculos de dança contemporânea. Exemplifico com as experiências da 7 th 
International Festival of Contemporary Dance da Bienal de Veneza 2010 (Fig. 39) com o grupo Chunk Move e sua coreografia Glow, ou com a produção Mortal Engine (Fig. 40), de 2008, em que a companhia australiana, com coreografias de Gideon Obarzaneks, experiencia novas condições espaciais através da projeção de formas abstratas, sincronizadas aos bailarinos, em telões ao fundo e no chão do palco.

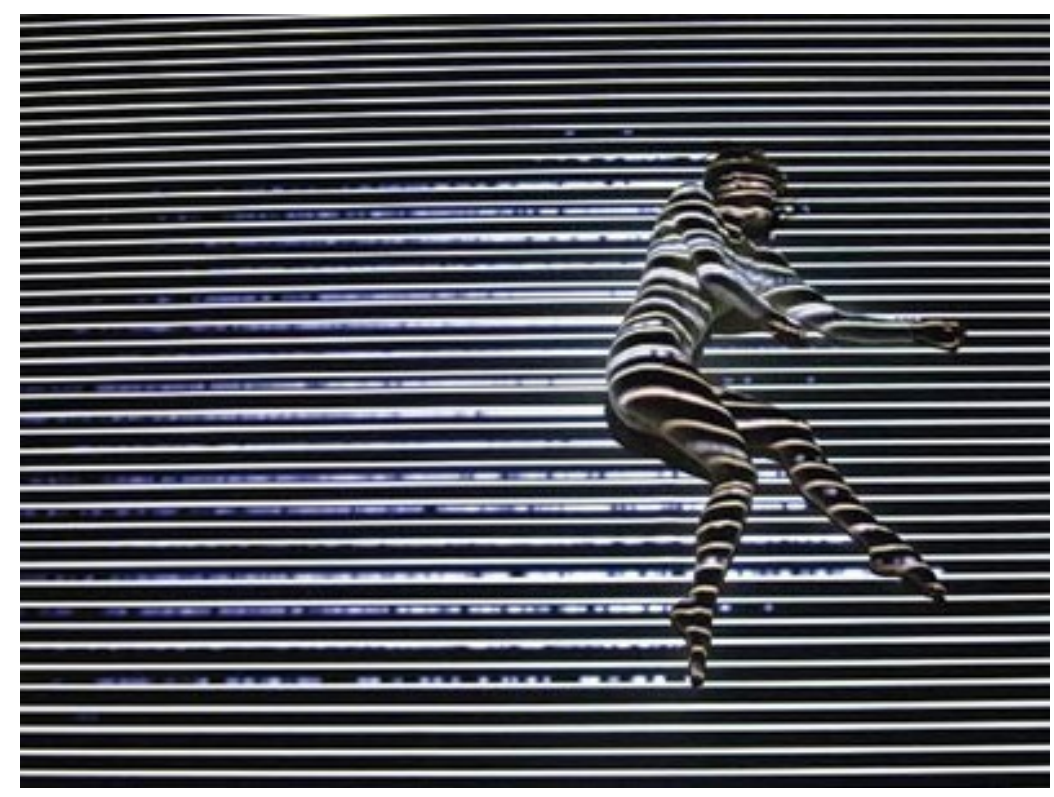

Fig. 39 Cena de espetáculo Glow, do grupo Chunk Move, de 2010

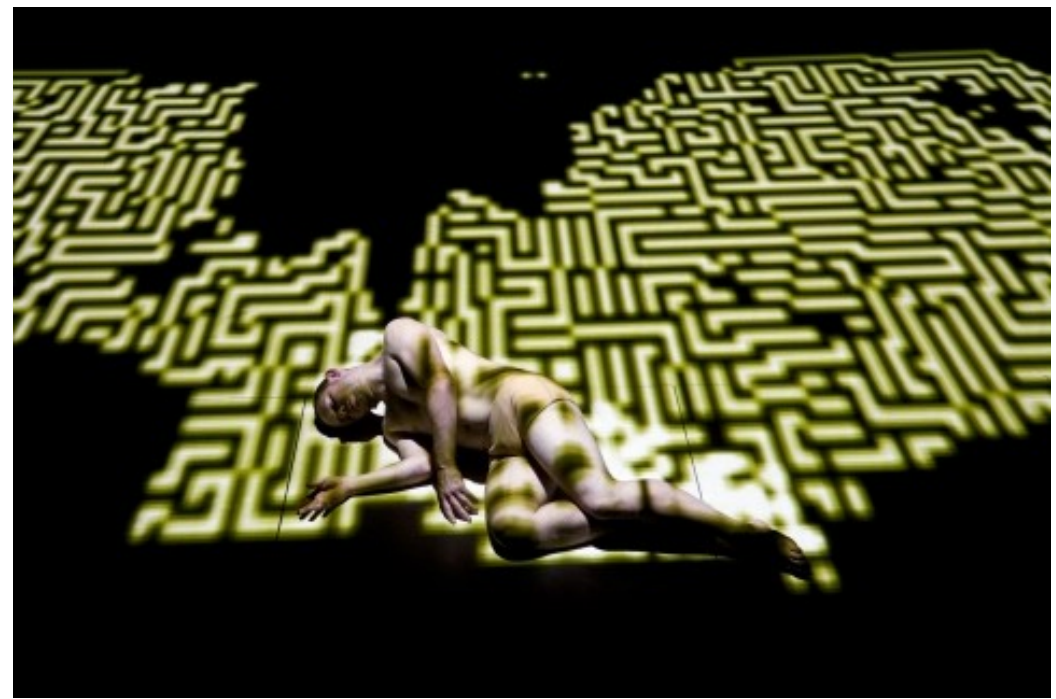

Fig. 40 Cena de espetáculo Mortal Engine, do grupo Chunk Move, de 2008

Tomo também exemplos mais radicais, como a integração entre dança e computação gráfica em 3D, experimentada pela dançarina Julia Mach em sua obra 'Stravinsky's The Rite of Spring' (Fig. 41), que podia ser apreciada com ajuda de óculos de 3D. A plateia que via a criação de muitas imagens abstratas junto aos movimentos do seu corpo coreografado, sob direção técnica de Klaus Obermaier. Aqui a ideia de 
espaço é confrontada com a ilusao de volume em 3D, perceptível somente através de recursos de captaçao e projeção tecnológica, hoje cada vez mais desenvolvidos.

Percebemos esses valores em muitas produções cênicas atuais, em que a projeção não pretende apontar um único lugar, mas sim criar novas possibilidades através da edição de imagens não regulares e não reconhecíveis, em que as conjunções virtuais não coincidam com o estado das coisas ou estejam em oposição às personagens. São espaços abstratos mais soltos e elevados, semelhantes às imagens associadas ao inconsciente e às percepções espaciais de estados alterados da mente, por alucinógenos naturais ou químicos, formas abstratas e cores que se superpõem espaço em si, criando patamares e elevações para muito além das narrativas percebidas.

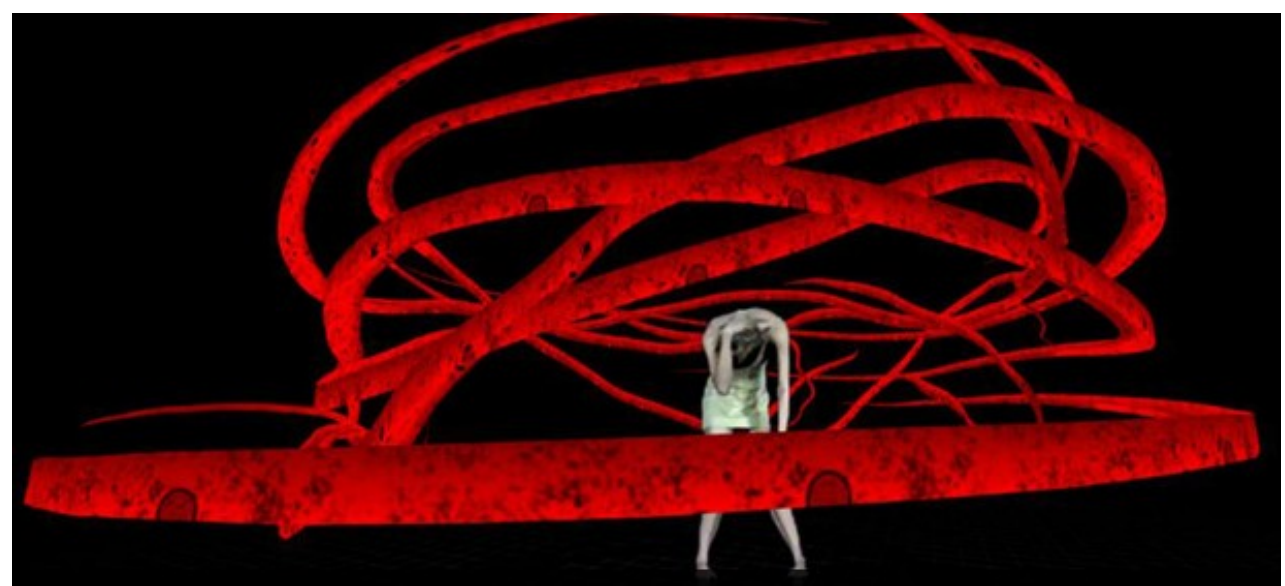

Fig.41 Espetáculo de dança em 3D 'Stravinsky's The Rite of Spring' da dançarina Julia Mach e direção de Klaus Obermaier, de 2011

Cito a obra ZEE, do norueguês Kurt Hentschläger ${ }^{25}$ (no FILE de 2010 em São Paulo) como performance imersiva em que imagens e cores, através de aparelhos de projeção e iluminação em uma sala, com densa fumaça branca, permitem criar uma espacialidade nova e abstrata, segundo o autor, semelhante aos efeitos de LSD.

O diferencial fica para as projeções que só acontecem na retina de cada espectador, num jogo de impacto de rápidas projeções stroboscópicas que criam um

\footnotetext{
${ }^{25}$ Kurt Hentschläger, austríaco, responsável pela obra ZEE, veio pro FILE 2010, com uma performance imersiva, por sessões de no máximo oito pessoas por vezes. O "espectador" entrava numa sala completamente preenchida por fumaça e experimentava sons graves (sobretudo de subwoofers, pra dar aquela sensação de "tremor" invisível do corpo) e luzes coloridas (geradas por strobos que acoplados a "color changers" - que causava uma mudança muito rápida das cores). Por conta da superfície de fumaça, a luz na retina do "espectador" gerava imagens aleatórias (as imagens mais frequentemente testemunhadas eram "mandalas" e "caleidoscópios"). Ele experimentava essa sensação por aproximadamente doze minutos.
} 
resíduo na retina. Muitas vezes, o espectador perde a noção de espacialidade real e entra em estado de tontura e até de convulsões e vômito. Aqui, a ideia da imagem abstrata e projetada é levada à máxima leitura de imersão e subjetividade, e mostra como a ideia de espacialidade pode e deve ser rompida, expandida e até reconstruída de forma poética-lírica por meio das possibilidades das linguagens audiovisuais existentes hoje.

\subsection{A cena no ciberespaço}

Se antes as artes cênicas buscavam uma cineficação da cena, ou seja, um diálogo / mistura dos recursos do cinema e do vídeo com as artes cênicas, como vimos no início desse capítulo, penso que agora elas acordam para uma possível internetização, em que há a ideia de portais que se abrem ao mesmo tempo, unindo espaços tão distantes como cidades e países em tempo real através de simples programas da internet. Eles podem, com rapidez e custo reduzido, provocar e possibilitar a transmissão de cenas em tempo real entre atuantes de vários pontos espalhados pelo mundo.

Transmissões simples, via programas como M.S.N e Skipe, já são usadas em trabalhos de teatro, dança e performance, e a internet cada vez mais aparece como protagonista de espetáculos cênicos, aglutinando pessoas e até operando com recursos tão inusitados como ilimitados.

Cito o caso do grupo brasileiro Os Satyros com seu experimento Cabaret Stravaganza, de 2011, dirigido por Rodolfo García Vázquez, que utiliza recursos do teatro expandido para flertar com recursos da internet (transmissão ao vivo de sequências, trechos da obra em blogs, sites e redes sociais que se misturam repatriando a ideia de espaço da cena). Agora podem acontecer parte ao vivo no teatro e parte no mundo cyber da internet.

Em entrevista concedida para esta pesquisa, Rodolfo Garcia Vásquez observa:

O teatro expandido, para falar do humano, terá de ir além dele. O ator e o espectador expandido serão aqueles que, além dos seus próprios corpos, carregarão suas próteses cibernéticas, de celulares a operações cirúrgicas, de identidades físicas a identidades digitais. $O$ ator do novo teatro se expandirá em apetrechos tecnológicos que completarão sua performance cênica. $O$ conceito de atuação se ampliará. O corpo físico do ator será sua realidade carnal original e suas próteses incorporadas, tornando-se plataforma a partir 
da qual o ator expandido realizará suas investigações reais e virtuais. Ao mesmo tempo, o ator expandido dialogará com um espectador que não estará ali apenas com seu corpo, mas com todas as suas próteses cibernéticas, de celulares a identidades virtuais. Deste encontro de ciborgues, surge esta pesquisa teatral. (VÁZQUEZ, 2011)

A peça Cabaret Stravaganza prevê uma experiência com o teatro expandido, apresentado pelos Satyros, visto que sua estreia digital acontecerá a partir do Projeto Lou-Leo, em que Leo Moreira Sá, um transexual masculino e artista do grupo, acompanhado de uma série de médicos e especialistas, se submeterá a um processo cirúrgico de adequação física de seu corpo à sua identidade de gênero, sendo mais um passo da transgenitalização.

Tal projeto se dará através de crowdfunding (financiamento colaborativo), em que a Internet se torna uma parte da própria pesquisa e da peça em fase de criação. As transformações advindas do procedimento cirúrgico de mastectomia para a reconstrução física do corpo de Leo Moreira Sá serão acompanhadas de perto pelos financiadores do projeto.

A partir da estreia, os espectadores poderão assistir, ao vivo e em tempo real, de que maneira o projeto de transformação física do artista e o financiamento digital estão evoluindo. Antes e após o espetáculo, um hotsite dedicado à cena permite ao espectador continuar a acompanhar o processo, com detalhes do projeto, com palestras com artistas envolvidos e pesquisadores discorrendo sobre questões relacionadas ao teatro expandido e a temas do espetáculo ${ }^{26}$.

Como percebemos, a internet, além de se configurar como apoio, pode transmitir e armazenar dados, histórias e imagens (ou cenas) e estas usadas ou não no espetáculo em forma de projeção de imagens ou na forma de acessos reais aos sites relacionados. São ações paralelas que criam a ideia de rizoma para além da cena em si, possibilitando uma exposição cultural que está disponível além dos museus ou espaços para eventos. O uso da internet pelas artes cênicas facilita a inserção de muitos artistas no mercado cultural, sem fronteiras.

O cenário das possibilidades entre artes cênicas, artes e recursos digitais e da internet. Meio de divulgação por excelência, a internet é propagadora dos mais

\footnotetext{
${ }^{26}$ Participo deste projeto acompanhando os ensaios e ministrando palestra elucidativa (realizada em 26 de setembro de 2011) sobre características do teatro expandido que nesse projeto utiliza de recursos de projeções de redes sociais
} 
diversos assuntos e descobre um mundo de possibilidades que expõe a arte entre interfaces digitais na perspectiva de dispositivos móveis, como celulares e tablets.

O que pode mudar quando a cyber realidade encontra as possibilidades hipertextuais de novas dramaturgias e encenações com recursos de projeção e transmissão cada vez mais rápidos? Claramente aponto que as fronteiras e os limites de territórios geográficos ou estéticos, são rapidamente alargados.

Por outro lado as interferências, tanto em nossos próprios corpos quanto na ordem natural, estão realizando transformações inéditas. O sequenciamento do genoma humano, as cirurgias plásticas e as pesquisas desenvolvidas por grandes corporações com alimentos transgênicos visando à alimentação em massa de bilhões de seres humanos estão nos levando a redefinir a própria relação com a natureza.

Se a construção da civilização sempre partiu do embate contra a natureza caótica e poderosa, hoje essa mesma natureza, mais do que dominada, passa a ser também construída pela própria humanidade. Percebo que se comprovam as contribuições do uso das imagens tecnológicas no modo como se processa a criação e a percepção de espaços cênicos.

Vimos, por meio de grupos e artistas antes citados, que além da busca de uma cineficação das artes cênicas, as relações entre cinema e vídeo, somadas às artes da presença, podem modificar as relações entre espaços que se tornam rapidamente mutáveis. E essa investigação aponta que ter em mãos recursos tecnológicos pode redefinir as qualidades de lugar, espaço cênico e espacialidade de forma mais abrangente.

Haja vista que hoje os espaços virtuais do cinema /vídeo já cedem lugar à internet em cena, portais que se abrem ao vivo se relacionando com outros espaços em territórios outros. Cidades, países e continentes se abraçam em tempo real, subvertendo as espacialidades que antes eram limitadas. Com a inclusão das tecnologias digitais, podemos ampliar a ideia espacial de uma obra com simples transmissões ao vivo e até interações entre público e atuantes de lugares tão distantes como possíveis.

A grande maioria dos artistas escolhe a internet para a criação artística por suas características específicas, como o uso da hipermídia, a instantaneidade, a interatividade, a imaterialidade, o alcance mundial e a reprodutibilidade infinita. 
Muitas destas características já existiam antes do advento da rede mundial de computadores, mas é aqui que todas elas se encontram em um mesmo meio.

A internet, sob uma ótica regressiva, é uma soma dos veículos de comunicação impressos (jornais e revistas), do rádio e da televisão, podendo ainda ser encontradas nelas características do telefone, do fax e até mesmo do cinema. Ao acúmulo de características de muitos meios - imagens, sons, texto e animações - em um só, dá-se o nome de multimídia.

Esse termo pode adquirir significados diferentes conforme o contexto em que é utilizado: costuma-se chamar de multimídia artistas que diversificam sua produção em vários meios distintos. Com a inclusão do hipertexto e seus links na rede e em CDROMs, a multimídia se torna hipermídia:

\begin{abstract}
O que distingue a hipermídia é a possibilidade de estabelecer conexões entre as diversas mídias e entre diferentes documentos ou nós de uma rede. Com isso, os 'elos' entre os documentos propiciam um pensamento nãolinear e multifacetado. O leitor em hipermídia é um leitor ativo, que está a todo o momento estabelecendo relações próprias entre os diversos caminhos. (LEÃO, 1999,p.16)
\end{abstract}

$\mathrm{Na}$ Internet, a instantaneidade é explorada principalmente por meio das webcams, câmeras conectadas à rede mundial, que na maioria das vezes transmitem imagens ininterruptamente. $\mathrm{O}$ artista-cientista e performer Eduardo Kac desenvolve, desde 1989, uma forma de arte que denomina telepresence art. Em que um dos seus trabalhos mais conhecidos utilizando internet e webcams, Rara Avis, de 1996, o observador, via rede, podia habitar virtualmente um corpo de um pássaro-robô que se encontrava dentro de um aviário. Diana Domingues define como arte interativa a produção artística que

possibilitada pela inclusão das novas tecnologias digitais nas práticas artísticas, modifica e coloca novos modos de fruição para o público. A intenção é propor o trabalho artístico não mais como mera criatividade do autor, mas como possibilidade de ser fruído, distribuído em rede, conectado através de terminais de computador, sempre solicitando uma ação num determinado ambiente onde sensores, sintetizadores, mouses, teclados ou outros aparatos que captam o corpo, fazem gerar novas situações ao trabalho proposto pelo artista. Cada indivíduo pode se conectar, agir, modificar, intervir. Na Web e em outros meios tecnológicos, a interatividade aliada a instantaneidade de respostas a cada estímulo do indivíduo, marca a passagem da arte da representação para uma arte muito mais comportamental. (DOMINGUES, 1997, p.94) 
A arte interativa não é só um resultado visual, mas também o processo no qual se insere o indivíduo. A interatividade na internet apresenta-se, na maioria das vezes, nas decisões em textos hipermídia (utilizando-se dos links clicáveis) e por ações em ambientes virtuais. A imaterialidade é outro elemento importante dentro do discurso poético de artistas que produzem trabalhos especialmente para a internet - os web artistas.

A busca por meios e procedimentos imateriais dá-se junto com a busca de meios de propagação da informação de maneira instantânea, como o fax, o telefone, o vídeo-fone, a televisão e mais tarde, as redes de computadores. Todos os meios de comunicação de escala global ou regional juntos criam uma trama informacional de caráter imaterial, denominada ciberespaço. O termo é também usado freqüentemente para denominar a própria rede Internet, embora possua uma dimensão que a Internet ainda não possui.

Telefones, celulares, rádio e televisão; infra-estrutura de cabos de cobre ou fibras ópticas, ondas de rádio e redes locais (intranets, por exemplo) ou globais, tendo seus terminais de comunicação ou suas informações gerenciadas por computadores, formam o ciberespaço. (DUARTE, 2000, p.150)

Esse novo conceito de espaço sem referencial físico cria o que se pode chamar de ciberlugares, locais de troca de informação e relacionamento que não acontecem em espaços físicos mas em um fluxo informacional. A melhor maneira de tentar entender esse conceito é pensar onde ocorre um bate-papo via internet: no conjunto de computadores conectados a uma mesma sala de bate-papo, em cada um deles ao mesmo tempo.

'A obra de arte na era de sua reprodutibilidade técnica', um dos marcos da reflexão crítica sobre a produção cultural, ensaio escrito por Walter Benjamin, em 1936, propõe uma mudança nos conceitos da estética clássica, acreditando que a possibilidade de reprodução quase infinita das imagens altera o cerne da experiência artística $^{27}$. Embora na época, Benjamin tenha-se baseado principalmente na fotografia e nos primórdios do cinema, muito do que foi dito por ele hoje vale para entender o

\footnotetext{
${ }^{27}$ Benjamim (1892-1940) foi um ensaísta, critico literário, tradutor, filósofo e sociólogo judeu alemão. Associado à Escola de Frankfurt e à Teoria Crítica, foi fortemente inspirado tanto por autores marxistas como Georg Lukâcs e Bertold Brecht. No ensaio em questão aborda a arte do século XX, a era digital e que a analisa a sua existência na era da cópia e da fotografia.
} 
que acontece na internet, em que a cada acesso uma cópia é criada. Benjamin entendia a reprodutibilidade como algo positivo

\footnotetext{
por desmascarar a ideologia elitista da estética ocidental. Para ele, a arte não deveria ser pensada em oposição à indústria cultural, mas dentro dela. $\mathrm{E}$ as tecnologias seriam instrumentos para desmistificar teorias supostamente universais do belo, mostrando que, na verdade, elas não passavam de visões de classe sobre códigos socialmente compartilhados de comunicação (ANDERÁOS, 1997, p. 56)
}

A reprodutibilidade seria o fim da arte aurática - o culto ao objeto de arte único - e da autenticidade. E na rede, onde um trabalho de arte pode ser infinitamente reprodutível essas características desaparecem definitivamente. É claro que não se pode resumir a escolha de um artista por um meio em especial simplesmente por algumas características gerais.

É certo que a busca pelo novo, a instantaneidade, a interatividade, o uso da hipermídia, o caráter imaterial, o alcance mundial e a reprodutibilidade infinita são pontos tão importantes quanto os motivos pessoais do artista - como o baixo custo de divulgação de um trabalho ou mesmo a maior facilidade de lidar com o computador. Nestas considerações, passamos a falar sobre os trabalhos de arte realizados especialmente para a Internet e novos paradigmas de "espaço".

Vejo que com a entrada na era cibernética, os artistas são confrontados com novos contextos tecnológicos e culturais, novas práticas do espectador e novos instrumentos, e o teatro tradicional e clássico se afirma como um espaço 'santificado', resistente às evoluções trazidas pela era digital.

A relação que se estabelece com outras artes, entre o desenvolvimento tecnológico e as mudanças estéticas, não tem importância para o teatro atual? Se o teatro é um prisma através do qual o espectador pode acessar a realidade, como ele pode dar conta das novas percepções de espaço e tempo que acompanham a virtualização do mundo?

Ao tornar-se um conservador das formas tradicionais de representação, as artes cênicas nos mostra os espelhos que refletem uma realidade que se desvanece em novos espaços ao mesmo tempo que se constrói novas e ilimitadas formas de ler a espacialidade hoje em cena. 
Se soubermos ter a generosidade e a paciência de entender as novas relações entre o mundo digital e o mundo real, o mundo que pode ser agora plugado além de mesclar imagens tecnológicas, a relação espacial da cena pode realmente rasgar fronteiras espaciais, como não poderia ser feito numa época onde a transmissão ao vivo de cenas só era possível por recursos via satélite das redes de televisão.

Nossa ideia de tecnologia e de espaço nos dias de hoje, como vimos até aqui, é alterada e expandida num cosmos de possibilidades estéticas que na verdade ainda engatinham. Não podemos frear o cruzamento das linguagens artísticas, assim como nao podemos frear o desenvolvimento das mídias e o cruzamento dessas com o velho modo de representar. Estamos na infância de novos modelos de espacialidade e presença.

Todos os homens se falarão, compreenderão seus idiomas e quase se tocarão, mesmo estando uns num hemisfério e outros em outro Leonardo da Vinci (1452-1519) 


\section{Capítulo 2}

A Imagem-Tempo: A imagem tecnológica na criação de efeitos de tempo e memoria: passado e futuro

A velocidade de mudanças tecnológicas esta mudando as nossas vidas. Não é tanto uma revolução. É mais uma extensão de nossa relação como tempo presente. Merce Cunningham

O público que ver, ele não quer mais ouvir. É essa a justificativa da encenação moderna e é preciso evitar a tentação de pensar que isso ocorra em detrimento da inteligência ou da sensibilidade. É um outro meio lógico do qual o texto dispõe; já que o público aprendeu a olhar, o autor dispõe, para exprimir certos sentimentos, de meios visuais. E a encenação recupera o que o texto perde. Manu Jacob

Olhar é sempre mais que se vê. Maurice Merleau-Ponty

\subsection{Um primeiro olhar}

Como já abordei anteriormente, as tecnologias da imagem podem alterar e expander as relações de espaço, mas e as relações de tempo? Quais seriam as possibilidades de novas formas de recuperar memórias e tempos (passados e futuros) com o uso de imagens tecnológicas na cena atual? Qual é o lugar das contribuições dessas novas tecnologias da imagem em diálogo com questões a cerca do tempo?

Pensando nessa gama extremamente rica de possibilidades de experienciar o espaço-tempo que a cena contemporânea oferece, pretendemos nesse capítulo discutir o modo como se presentifica essas relações temporais, sublinhando a linguagem cinematográfica/videográfica e a soma da potência cênica, da presentificação do tempo aqui e agora, como expressão artística sobre a qual iremos dirigir nosso olhar para realizar essa reflexão.

Nesse intuito, procuramos estabelecer uma interlocução com o pensamento filosófico de Merleau-Ponty, no que se refere à compreensão do espaço e do tempo

Falar de espaço-tempo numa primeira instância é reconhecer que essas dimensões estão implicadas no próprio existir. O fenômeno do movimento engrenado e situado no desdobrar-se de uma vida manifesta a implicação dessas dimensões fundadas na nossa relação com o mundo e no mundo (MERLEAU-PONTY, 1994, p.73)

No que se refere às relações espaço-temporais na cena contemporânea, podemos observar que várias das suas produções vem propondo uma flexibilização da vivência do espaço e do tempo ao retratar corpos que buscam não se conter na sua própria extensão. Ao abarcar o 'entrelaçamento de diversas técnicas de potências 
cênicas, de uma pluralidade de linguagens e de uma multiplicidade de ações cênicas, sem negar os estilos que a antecederam' (SILVA, 2005, p. 17), entendemos que a cena contemporânea possibilita um redimensionamento dos usos do espaço e do tempo do corpo nas imagens tecnológicas, inserindo a voz, o canto, o virtual e materiais diversos, como elementos que podem integrar a configuração desse gênero de cruzamento entre cena presente e cena virtual.

No Brasil é possível destacar grupos e companhias, como o Cena 11 de Santa Catarina, que apesar das suas particularidades ressaltam em comum a possibilidade de trabalhar numa perspectiva de hibridação de linguagens, de não fixação em um único código temporal, instituindo muitas vezes um modo de configurar o movimento dançado/encenado/performado de forma inovadora, extremamente plástica, sem estabelecer uma hierarquização entre os códigos utilizados. O que traz dessa forma rupturas e novos entendimentos entre tempo real, dos atuantes / dançarinos e performers no palco, e imagens deles próprios, em projecões em tela ao vivo ou prégravado.

Durante muito tempo o teatro foi 'serviçal' das unidades aristotélicas (regra das três unidades ação, tempo e lugar), o que serviu para um ruptura cada vez maior com as questões do tempo na contemporaneidade, que recharça as regras e subvertem o tempo em massa transitória. Às vezes, a tecnologia pode contribuir como manipulação radical rascunhando novas possibilidades entre imagens tecnológicas e resultados com o tempo, como perceberemos em produções de artistas e grupos que citarei adiante.

Em muitas experiências com projeção de imagens já se nota a intenção de mutabilidade do tempo visto que nem sempre os tempos entre o que se projeta em cena está alinhado com a cena em si, ao vivo. O simples uso de imagens tecnológicas em cena pode recuperar estranhamentos entre as imagens, virtual e real. A seguir, recupero momentos das artes cênicas em que a questão das imagens também se relacionam com as questões do tempo.

\subsection{A imagem-tempo nos primeiros Happenings}

Pelo próprio caráter livre e anárquico, os happenings traziam desde seu início algumas experiências com imagens que tratavam de modificar as relações com o 
tempo. Apesar de ser definida por alguns historiadores como um sinônimo de performance, o happening é diferente porque, além do aspecto de imprevisibilidade, geralmente envolve a participação direta ou indireta do público espectador. Em alguns nota-se que a questão da durabilidade é central, como a fixação de certas imagens ou até mesmo na interatividade.

Durante os anos 50, filmes e slides foram projetados em paredes e tetos em alguns dos primeiros happenings, incluindo o estrondoso trabalho de Allan Kaprow, 18 Happenings in 6 Parts, de 1959, e a seminal performance intitulada 1952 Black Mountain College realizada por renomados artistas como John Cage, Robert Rauschenberg e Merce Cunningham.

Rauschenberg produziu slides abstratos, criados com gelatina colorida feito sanduíche entre placas de vidro e clipes de filmes projetados no teto, enquanto as imagens, gradualmente, se movem do teto para a parede e para o chão.

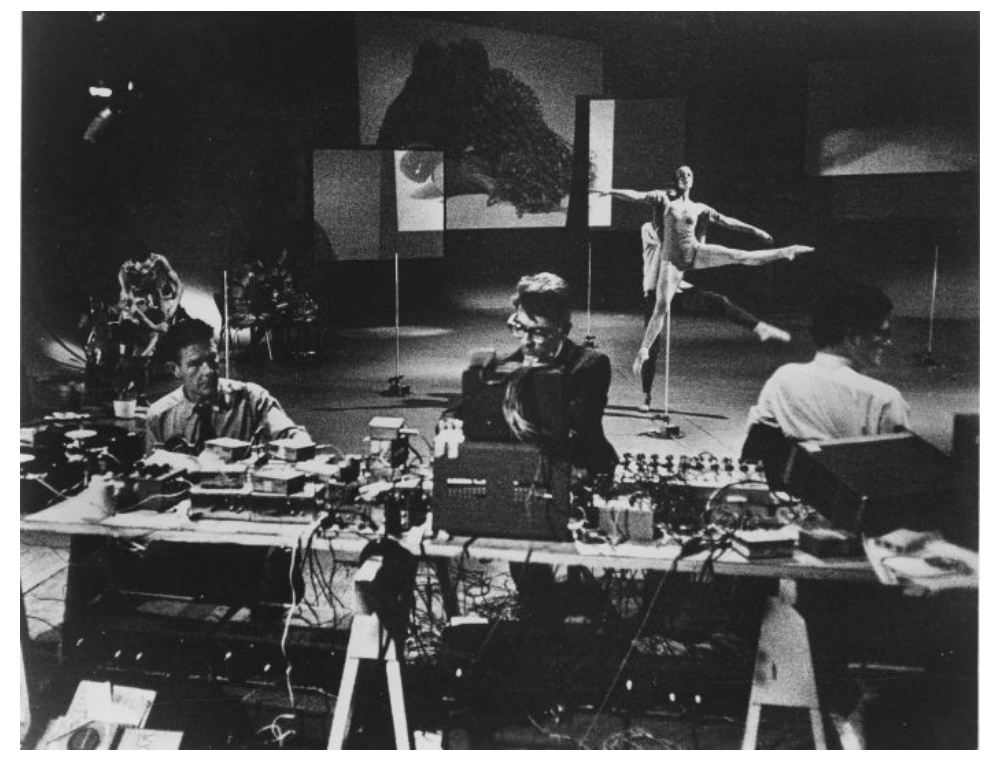

Fig.42 Cena do happening Variations VII, de 1965, com John Cage, David Tudor, Gordon Mumma Caroline Brown, Merce Cunningham, Barbara Dilley

Para Jean Jacques Lebel, autor de vários happenings em Paris, o 'primeiro objetivo é transformar em poesia a linguagem que a sociedade de exploração reduziu ao comércio e ao absurdo' (1969, p.22). Os happenings de Jean-Jacques Lebel já incorporavam a projeção de filmes no corpo nu de seus performers, como em Stoned in the Streets, em Amsterdã, de 1966, em que uma jovem pintora inglesa se funde com projeções de filmes de telas de Botticelli. No happening Despedaçamento, ocorrido em 25 de maio de 1965, durante o Segundo Festival da Expressão Livre de Paris, Lebel 
descreve:

do lado direito, começa a projeção de um cinema-colagem em cores. Cinco ou sei filmes aparecem simultaneamente na tela. Uma colagem que durará renovando-se sempre, durante mais ou menos uma hora, (por exemplo: o filme de Michaux sobre a mescalina, um sobre a feitiçaria em Dahomey e outro sobre partos - a Conduta Ativa do Parto, projetado às avessas, de modo que os bebês entram novamente no ventre das mães, em vez de saírem .Filmes de atualidade política no Vietnã, em São Domingos). Durante toda a apresentação do happening, o filme-colagem continua com o acréscimo da banda sonora e atos espontâneos que se desenrolam pela sala (LEBEL, 1969, p.80)

Artistas rebeldes, engajados, inconformados com a comercialização e exploração da arte e contra as outras formas de opressão da sociedade, acabam usando a tecnologia como denúncia. Em 1958, o alemão Wolf Vostell, do grupo Fluxus, colocou um conjunto de aparelhos de televisão na janela de uma loja de departamentos parisiense para a peça TV De-collages, em 1958.

Aos poucos percebemos um crescimento na utilização da tecnologia do vídeo para construção de imagens que tratam também do tempo e, nesse sentido, as questões do tempo cinematográfico irão diferir muito com a aparicão do vídeo. Enquanto para a estética cinematográfica o tempo é mais lento próximo do real (Manifesto do Cine Olho, de Vertov), os anos 60 marcam o início das experiências em vídeo e da vídeo linguagem, que por si só já acelera o tempo e as facilidades de edição. O que aponta para imagens em justaposição, ritmos fragmentados e tempo acelerado, como na tradição dos vídeoclipes.

\subsection{As inovações de Nam June Paik}

O artisita coreano Nam June Paik trabalhou em diversos meios da arte, sendo freqüentemente creditado pela descoberta e criação do meio conhecido como videoarte. Sua estética seria desenvolvida em trabalhos esculturais e monumentais usando centenas de aparelhos de TV mostrando cenas especialmente escolhidas e abstratas imagens coloridas.

Segundo Paik, 'a TV tem-nos atacado durante toda nossa vida (...) agora nós estamos batendo de volta! (...) a Vídeo Arte imita a natureza, não em sua massificação ou em seu aspecto físico, mas na sua estrutura temporal, na sua irreversibilidade' 
(2007, p.55). Nam June Paik especializou-se na arte eletrônica; participava de um movimento de arte neo-dadaísta, conhecido por Fluxus, que chegou à Alemanha na década de 60, e este movimento unia ao Concerto tradicional o som de objetos e elementos inusitados que não instrumentos musicais.

Sua grande estreia foi no Exposition ofmusic-eletronic television, espalhando diversos televisores por todos os lugares utilizando imãs para distorcer as imagens, obra conhecida como TV Magnet e que deu origem a vídeoarte. Foi um dos artistas responsáveis por transformar a vídeoarte em arte respeitável, digna de ser apresentada em grandes museus e galerias, como o Guggenheim e Whitney, que mostraram em anos diferentes uma retrospectiva da arte deste artista.

Arte como forma de expressão surgiu em Paik a princípio como resultado de movimentos anti-guerra e de cunho político dos anos 50 a 70 . Ele trabalhava com cinema, televisão, fitas cassetes e esculturas inanimadas. Recentemente tinha se mostrado interessado à tecnologia a laser. Sua última instalação, denominada 'pósvídeo' combina a imagem cinética movida a laser num tecido tencionado, enquanto cascatas de água e fumaça são vistos sobre a imagem.

A combinação do cinema e da TV nos é apresentada como uma advertência aos novos meios que irão surgir, revolucionando a tecnologia como nós a conhecemos. Com seu trabalho ele visa criar uma televisão universal cuja compreensão seja aberta ao mundo, cujo conteúdo seja um resultado das várias visões e análises propostas.

Fez trabalhos com colaboração da compositora Charlotte Moorman em performances musicais e com o uso de vídeos que contestaram a maneira tradicional de tocar e ouvir música. Em TV Bra, de 1968, Moorman é filmada sem sutiã, tocando violino e usando dois espelhos circulares sobre os seios, que refletiam câmeras focadas em seu rosto.

Paik e Moorman foram presos, em 1967, pela apresentação sem sutiã na Sextronique, em que as costas de Paik, sem camisa, tornaram-se o baixo para o arco de Moorman. 'Eu queria agitar as águas monótonas compostas por mulheres e homens assexuados, trajando ternos pretos, que tocavam música' (BERGHAUS, 2007, p.199), disse ele certa vez.

Em outros projetos polêmicos, como Concerto for TV, Cello and Vídeo Tape, de 1971, ela passava seu arco por pilhas de aparelhos de televisão que mostravam 
imagens dela, simultâneas e pré-gravadas, passando o arco pelas televisões (Fig.41) e o interesse de Paik era visualizar o tempo. 'É preciso enfatizar', ele escreveu em 1962, antes de sua apresentação na Galeria Parnass, em Wuppertal, 'que meu trabalho não é pintura, nem escultura, mas sim uma arte temporal: não gosto de nenhum gênero em especial' (BERGHAUS, 2007, p.198).

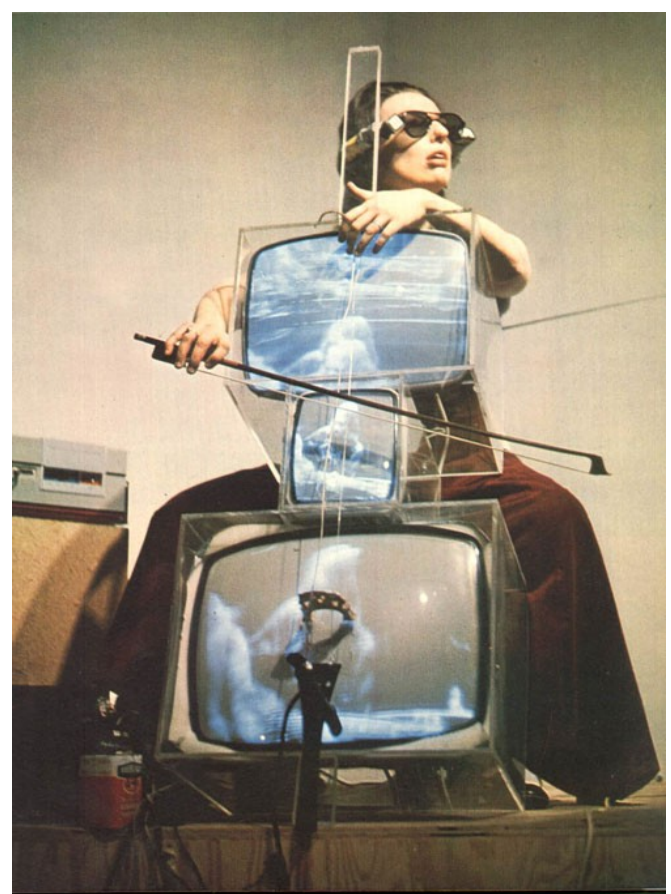

Fig.43 Concerto for T.V. Cello \& Videotapes, de Nan Jun Paik e Charlotte Moorman

As obras de Paik nos faz pensar sobre as novas possibilidades de uso dos meios tecnológicos e, principalmente, a reflexão sobre a cultura de massa e a possibilidade de uso mais elaborado e libertador desses veículos. A aula mais importante a ser tomada de Paik é que o artista tem que saber olhar para os movimentos conceituais dos anos 60, aprender com eles e saber criar formas alternativas de expressão tomando como base a própria tecnologia que impacta as nossas vidas.

Paik transforma não apenas as imagens mas o próprio aparelho televisivo como arte incorporando-o à sua escultura. Ele influenciou praticamente toda videoarte, contribuiu com uma das primeiras tecnologias inovadoras com seu sintetizador Paik/Abe, um mecanismo para colorização e manipulação de imagens, abrindo espaço para investigações posteriores como videoinstalações, performances e meios de produzir, ver e interpretar o vídeo. 


\subsection{A imagem-tempo invade o teatro e a dança}

O teatro soltou suas amarras a partir do texto dramático e se reinventou de formas vibrantes, de performances interdisciplinares, visuais e ambientais. Ao mesmo tempo, a dança foi se livrando de suas próprias raízes, de suas regras limitantes, quer clássica quer modernas, no trabalho de coreógrafos, incluindo Merce Cunningham, Ann Halprin, Trisha Brown, Lucinda Childs, Steve Paxton, Yvonne Rainer e Twyla Tharp.

O Living Theatre, importante companhia de teatro norte-americano, fundada em 1947, em Nova York, é um dos mais antigos e grupos de teatro experimental que combinou política revolucionária e misticismo para conceber o espetáculo Paradise Now, em 1968, em que o recurso vídeo já era sutilmente incorporado.

\footnotetext{
Essa interferência da teatralidade chama a atenção para os suportes dramáticos da linguagem fílmica, para aquilo que não deve ser exposto: a heterogeneidade do cinemático e sua dependência de uma situação "extracinematográfica". As convenções fílmicas são desnudadas pela exorbitância da teatralidade. O drama é a caixa-preta do filme. (MOTA, 2007, pág. 412)
}

Outro nível de representação alinha-se a projeção de imagens criando uma diversa referência de narrativas. A teatralidade passada para tela apresenta um horizonte de observância que compromete e interfere na identificação e compreensão do que se assiste, processo que pretendo analisar a seguir.

Com o surgimento de novas e mais revolucionarias tecnicas de projeção, edição e softwares para criação de produtos audiovisuais. Agora com a facilidade das novas tecnologias de projeção e o flerte cada vez maior com tendências da web, a projeção em cena deu grandes saltos desde as prioneiras experiências.

A cada nova experiência algo de novo era incorporado, de forma técnica ou estética, de forma que os anos 70 e 80 são importantes terrenos de experimentações das imagens tecnológicas, mas é sobretudo nos anos 90 e 2000, com a chegada dos recursos digitais, que as questões da imagem vão flertar com diversas temporalidades; às vezes se ajustando a elas, às vezes se opondo. Muitos artistas de outras áreas acabam por se render aos encantos da videolinguagem, o que acaba por acelerar as transformacões e contaminacões das artes cênicas pelas imagens tecnológicas. 
Como é o caso do artista norte-americano John Jesurun e o grupo teatral novaiorquino Wooster Group, que além de serem pioneiros no uso ostensivo do vídeo (uso de muitos televisores em cena e trasmissão de cenas ao vivo) influenciaram o trabalho de muitos artistas mais jovens nos Estados Unidos e em outros países; sobretudo outro grupo inglês, o Builders Association, cuja autodestruição é a definição virtual de um teatro pós-moderno com meios de comunicação de massa: 'Nós reanimamos textos teatrais clássicos, introduzindo-os em novos meios de expressão, $e$ depois remanejando-os dentro do contexto caótico da cultura global contemporânea.' (GIESEKAM, 2007, p.143).

Como em Jump Cut (Faust), de 1997, com textos de Jesurun e montagem visivelmente influenciada pelo Wooster Group, envolveu cenas de vídeo interativas e sofisticadíssimas, nas quais personagens do clássico Fausto de Goethe utilizavam cenas de um filme de Fausto (1926), do tempo do cinema mudo, de F.W. Murnau, e reagiam ao vídeo gerado por uma câmera colocada no palco.

Outras companhias de teatro experimental que quase sempre usam meios de comunicação de massa em seu trabalho incluem grupos como Squat Theatrer (fundado na antiga Chescoslováquia), Dumb Type (Japão), Impossible Theater (coletivo americano dos anos 80 cujo uso de métodos sofisticados nas produções, como meios de comunicação de massa, como Social Amnesia (Aminésia social), de 1986, tinha como objetivo criticar a tecnologia) e companhias associadas aos espaços alternativos para performances, como La MaMa ETC, em Nova York, para as quais artistas como Ping Chong com formação em cinema e dança, e o pesquisador Michal Rush, com formação em teatro e fotografia, também adotaram meios de comunicação de massa como elementos poéticos em obras abstratas que combinam música, dança e textos em ambientes visuais imagistas.

Porém nas relações entre imagem, tempo e memória as artes cênicas tiveram num artista canadense seus melhores resultados: é com Robert Lepage e seu grupo Ex maquina que as experiências temporais com uso de imagens tecnológicas dão um salto considerável. O uso das linguagens cinematográficas e videográficas fogem dos modismos e encaram uma funcionalidade em combinação com tramas que propõem um vem e vai no tempo, recuperando memórias de muitos personagens que se cruzam em tramas longas, no que alguns chamam de 'Teatro da memória' de Lepage. 


\subsection{O tempo na cena de Robert Lepage}

Como Robert Wilson, o diretor franco-canadense Robert Lepage trabalha com grandes formatos de multimídia. Com sua companhia Ex Machina, criou várias obras teatrais com meios de comunicação de massa, entre as quais Polygraph (Polígrafos), de 1990, Needles and Opium (Agulhas e ópio), de 1992 e The Seven Streams of the River Ota (Os sete afluentes do Rio Ota), de 1996, uma obra de sete horas que combinou filme, vídeo, música e dança, inspirada no cabúqui e no butô japoneses.

Rio Ota, que desdobrava e recorria a cenas em épocas diferentes do século XX, foi inspirada por uma visita a Hiroshima. Era uma obra complexa que utilizava de recursos do vídeo e da encenação para recriar e sobrepor fases do tempo, entrelaçando as vidas de pessoas que vivenciaram o Holocausto, o bombardeio de Hiroshima e a epidemia de AIDS. 'O tempo está implicitamente ligado a tecnologia', disse Lepage, que considera a existência de poesia na tecnologia e registra a tentativa usá-la de forma a não eclipsar a ação no palco. Sobre o uso de técnicas cinematográficas em cena, Lepage fala:

\footnotetext{
Eu não entendo tanto de cinema quanto de teatro, me interessa muito o cinema mas eu não domino sua linguagem caprichosa, é uma forma de arte muito nova com apenas 110 anos, e nós supomos que dominamos a linguagem mas ela está apenas começando. Interesso-me pelo cinema por ser uma outra forma de contar histórias. Por isso a maior parte dos meus filmes são adaptações de minhas peças onde posso explorar diferentes aspectos de um personagem, por exemplo, no "Far side of the moon", o uso de planos fechados, me fez aprofundar na composição dos irmãos para diferenciá-los. Ao mesmo tempo que o cinema possibilita o aprofundamento de certas questões, como a interpretativa, citada no exemplo, a concepção visual da peça era muito mais poderosa e poética que a do filme. $O$ que me interessa, portanto é explorar estes aspectos que o cinema possibilita e o teatro não. (BARONE, 2007, p.153)
}

Para discutir suas idéias, começo pelo espetáculo de 1984, Circulations, cujo ponto de partida tem dois objetos, um visual (carta) e outro sonoro (um curso de inglês num cassete) explorando os fluxos culturais entre a cultura francesa e a anglosaxã do hemisfério norte. Neste espetáculo a magia visual repousa sobre a simplicidade dos meios e não numa maquinaria sofisticada; rompendo com o mimetismo e indo em direção ao pensamento simbolista de utilizar o imaginário do espectador como espaço da mise en scene ou dos meios de seus prolongamentos. 
Em Circulations a temática nasce das imagens e não o inverso; dos objetos banais já citados, nasce todo um mundo. No espetáculo há diversas formas metafóricas de perceber o mundo; o teatro da imagem não nos apresenta o mundo como nossos olhos o vê (mimese tradicional) mas como nosso pensamento o imagina; o teatro da imagem deforma o real para abrir novas trajetórias não lineares. Por exemplo, quebra da perspectiva tradicional com o plano aéreo da cena Moon-hotel, em Circulations e certas cenas de Vinci e dos Sete afluentes. Com isto inaugura-se, no teatro de imagens, um possível 'meta-ponto de vista' via metáfora.

Em seguida analiso algumas características do uso de tecnologia das imagens no espetáculo 'Os sete afluentes do Rio Ota', informando dados sobre a origem e o processo criativo do espetáculo. Um dado interessante é a noção de holograma como metáfora.

O germe inicial da cena contém necessariamente a imagem de um holograma que reúne todas as informações relativas à forma; princípio de base para o trabalho de Lepage em que 'certas cenas constituem-se como verdadeiros microcosmos do espetáculo, (...) com um holograma que contém a imagem completa do objeto representado' (BARONE, 2007, p.153).

O teatro de imagens propõe um tipo de poética de jogo livre e fluido, da construção por fragmentos, uma construção em movimento, em que surgem novos territórios para criação e para o conhecimento. A obra teatral não mais se completa na cena, mas sim na relação entre artista e espectador, como construtores de rizomas dos sentidos, de circulações no interior da obra, integrando imagens e sons propostos a uma memória pessoal.

Lepage é um dos grandes nomes do teatro contemporâneo e também grande artista na fusão de tecnologia e cena que também usa as possibilidades da tecnologia no cinema, na ópera e em shows, como o espetáculo KA, do Cirque du Soleil, que tem sua direção e novamente abusa do uso de tecnologia como recurso. Ele afirma que foi influenciado pelos métodos de trabalho improvisados do diretor de teatro britânico Peter Brook, cuja companhia internacional com sede em Paris criou obras quase sempre baseadas em fontes clássicas e literárias, por exemplo The Mahabarata. Embora Brook tivesse sido tambem diretor de cinema no início da carreira ele não é significativo no que tange ao vídeo ao vivo, de grande formato, em sua produção de 
1992, The man who (O homem que), baseado no livro de Oliver Sacks, The man mistook his wifw for a hat (O homem que confundiu sua mulher com um chápeu), sobre um homem com lesão cerebral.

\begin{abstract}
O plurilinguismo é recorrente na obra do canadense. Presente como fio condutor na Trilogia, reaparecer com força intensa em Vinci e nos Sete Afluentes do Rio Ota. Podemos atribuir esse interesse do encenador num teatro de imagens, e não baseado em texto, foi mais facilmente exportáveis para o mercado Inglês. Nos anos setenta, oitenta, todas as pessoas que tiveram formação em Lecoq, por exemplo (Decroux, Barba, etc.), veio a Quebec e criou um teatro ou ensinou um teatro mais gestual, mais visual. Este ensinamento eu recebi no Conservatório de Arte Dramática de Quebec nos anos setenta e cinco, foi baseado no movimento corporal, a máscara, o trabalho físico. Pessoas que receberam essa formação fizeram, em seguida, um teatro de imagem. (BARONE, 2007, p.153)
\end{abstract}

A integração do vídeo veio um pouco mais tarde porque ele exige recursos que não eram necessariamente acessíveis para pessoas do teatro (Fig.44). É difícil, em Quebec separar o teatro gestual do teatro da imagem e então, nesses anos, a influência do teatro europeu e internacional começa a ser sentida com a dança-teatro de Pina Bausch e o teatro de Bob Wilson, trabalhos também considerados como teatro da imagem.

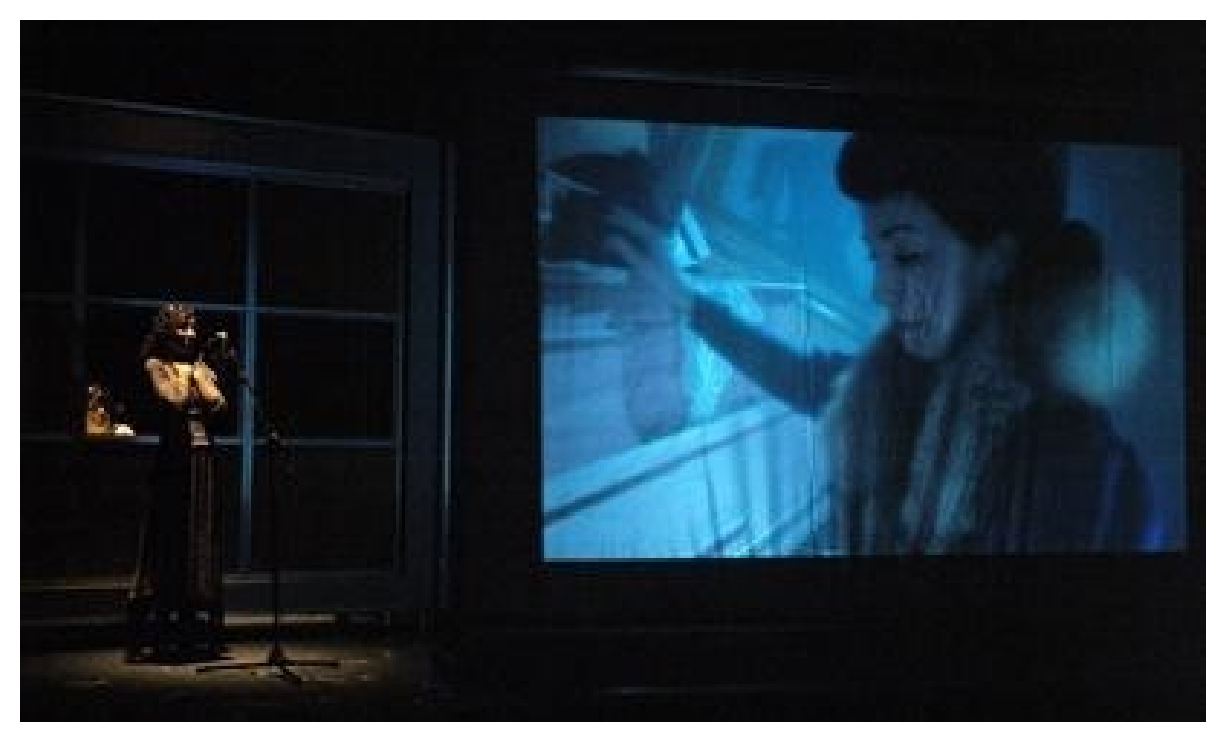

Fig.44 Cena de Lipsink, direção de Robert Lepage

Através de sete espetáculos criados e dirigidos por Robert Lepage (Vinci, Trilogia dos Dragrões, Agulhas e "Opio, Os Sete Afluentes do Rio Ota, Elsinore, Geometria dos Milagres e A Face Oculta da Lua) é analisado o modo singular pelo qual 
o encenador faz uso de sete elementos recorrentes em sua arte: o idioma, os objetos, as imagens, o espaço, a palavra, a memória e o jogo.

Apresentando a obra cinematográfica de Lepage, através da sinopse dos filmes Le Polygraphe, Nú, Le Confessional e La Face Cachêe de la Lune, relaciona sua criação teatral e cinematográfica, confluindo para a singularidade de sua poética multidisciplinar e híbrida. A vontade primeira de trabalhar um espetáculo que resultaria em Os Sete Afluentes do Rio Ota nasceu em Lepage, em 1993, quando esteve pela primeira vez no Japão (para dirigir Macbeth e A Tempestade no Tokyo Globe Theatre) e se fascinou com a cultura local. Além do impacto que sofreu com a diferença de percepção espacial, a visita a Hiroshima e a descoberta de seus contrastes, foi fundamental para a criação do espetáculo.

\begin{abstract}
Quando eu estive pela primeira vez no Japão, em 1993, eu visitei Hiroshima com um guia que, eu soube no último dia de minha visita, era um hibakusha, um sobrevivente da bomba. Ele tinha visto a bomba explodir com seus próprios olhos. Ele explicou que as primeiras coisas a serem reconstruídas em Hiroshima, foram as duas pontes. A cidade era construída as margens dos sete afluentes do Rio Ota, então era importante reestabelecer as conexões de transporte. Mas o que é interessante de notar é que eles construíram uma ponte Yin e uma ponte Yang, uma com formas fáicas e a outra com formas vaginais. Para que a vida retornasse a Hiroshima, eles tinham que prover a cidade de orgãos sexuais, de modo que uma metade pudesse acoplar-se à outra. Isto explica porque toda nossa atenção era voltada ao instinto de sobrevivência e a sexualidade, enquanto elemento de fecundidade (...) Se você quer revelar a vida e os instintos de sobrevivência e reprodução, você, as vezes, tem que abordá-los através da morte. Os Sete Afluentes do Rio Ota é inteiramente centrado neste contraste. Nada neste século representa a morte, o sentimento de vazio e a desolação tão bem quanto a bomba atômica. E ainda, para nós, ela inspirou um espetáculo muito vivo e extremamente sensual. Neste período extraordinário, eu aprendi que a recorrente aparição da morte e do suicídio em minhas peças tinha produzido o efeito contrário, que ela tinha nos levado de encontro à vida. (BARONE, 2007, p.153)
\end{abstract}

Documentos trazidos por Lepage do Japão foram explorados pelos atores, assim como o filme de Alain Resnais, Hiroshima mon Amour, cujo texto de Marguerite Duras inspirou o título da peça. O que se desenvolve, então, é um processo de brainstorm alimentado de muitas referências bibliográficas e iconográficas que passam a habitar a mesa de trabalho do Ex Machina.

Os atores vão sugerindo situações que são documentadas pelos lap tops e que serão utilizadas nas improvisações. Como fonte sensível, os atores partiram de uma máquina de fotografias instantâneas, que acabou gerando novas fontes, durante o 
processo de criação: a própria idéia do flash da máquina lembrava a explosão da bomba e a fotografia reveza seu papel, entre anteparo físico da memória e espelho que reflete o sujeito fotografado.

Os Sete Afluentes do Rio Ota tem início nos dias que se seguem ao primeiro bombardeio a Hiroshima, para contar a saga de diversas personagens que vão transitando entre gerações e países que vivem catástrofes modernas como o bombardeio e a consequente destruição da cidade de Hiroshima, o nazismo europeu e o holocausto dos judeus, a epidemia da AIDS e os sentimentos de desespero e necessidade de renascimento que acompanham essas vivências.

Montado em três fases de work in progress, o espetáculo estreou em 1994, no Festival de Teatro de Edinburgo, apresentando-se também na Inglaterra e na França. No ano seguinte, ganhou sua segunda versão, ampliada para seis horas de duração 'intermediadas por três intervalos de 20 minutos e um longo intervalo de uma hora para refeição' (COULBOURN, 1995, p.2) que estreou no Vienna Festival, na Áustria, viajando para Alemanha, Itália, Espanha, Suiça, Dinamarca e Japão, apresentando-se também no Canadá, ainda no final de 1995.

Em 1996, Os Sete Afluentes do Rio Ota chegou a oito horas de duração da versão final, que estreou no Quebec, cumprindo tournês pela Europa (Áustria, Alemanha, Dinamarca, Inglaterra, Suécia e França), América do Norte (Estados Unidos e Canadá) e Oceania (Austrália e Nova Zelândia)(Fig.45).

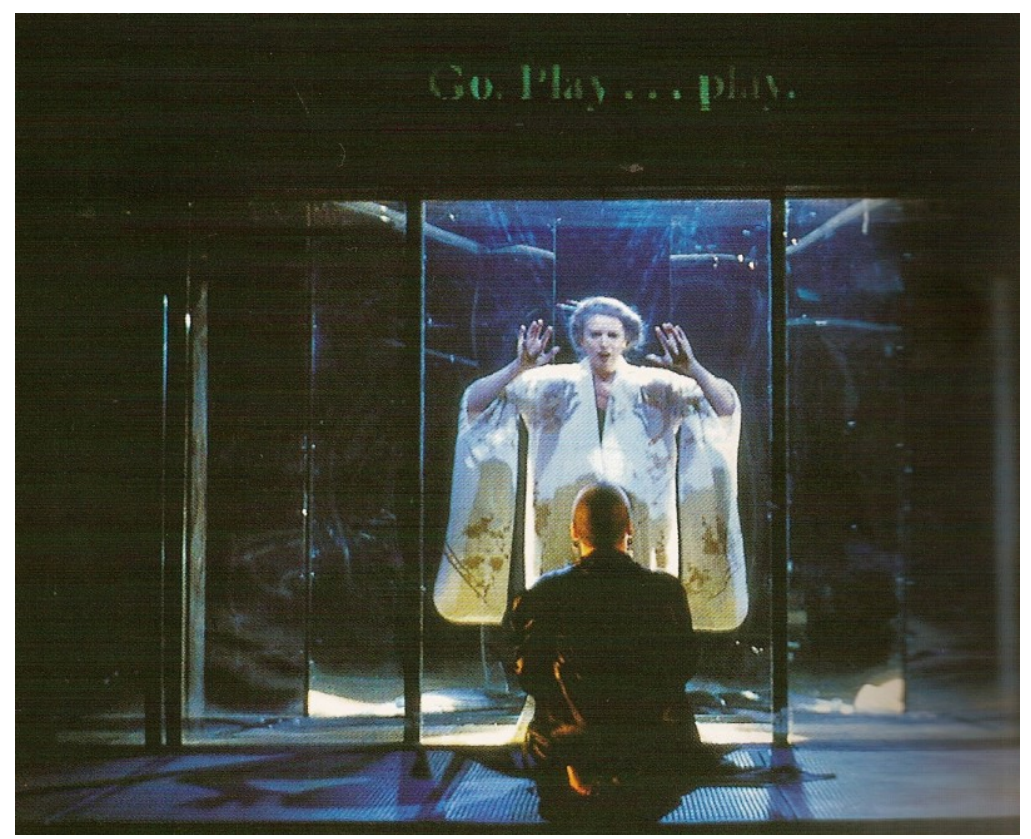

Fig.45 Cena de 'Os sete afluentes do Rio Otta', direção de Robert Lepage 
Em 2003, o espetáculo foi montado no Brasil, sob a co-direção de Monique Gardenberg e de Michele Matalon. Gardenberg, que havia fascinado-se com a montagem assistida nos Estados Unidos, em 1996, tentou trazê-la para o Carlton Arts, que produziu em 2001, mas como o Ex Machina não tinha a intenção de remontar o espetáculo, trouxe A Face Oculta da Lua.

A produtora e cineasta resolveu montar o espetáculo com uma equipe brasileira e, a partir do texto e de fitas de gravação da montagem original, enviadas pelo Ex Machina, realizou uma nova versão que se mostrou estritamente baseada na montagem original canadense, embora, em seu programa, Alberto Guzik afirme não se tratar de um clone da produção original de Lepage, mas uma leitura de Monique Gardenberg e sua trupe (Fig.46).

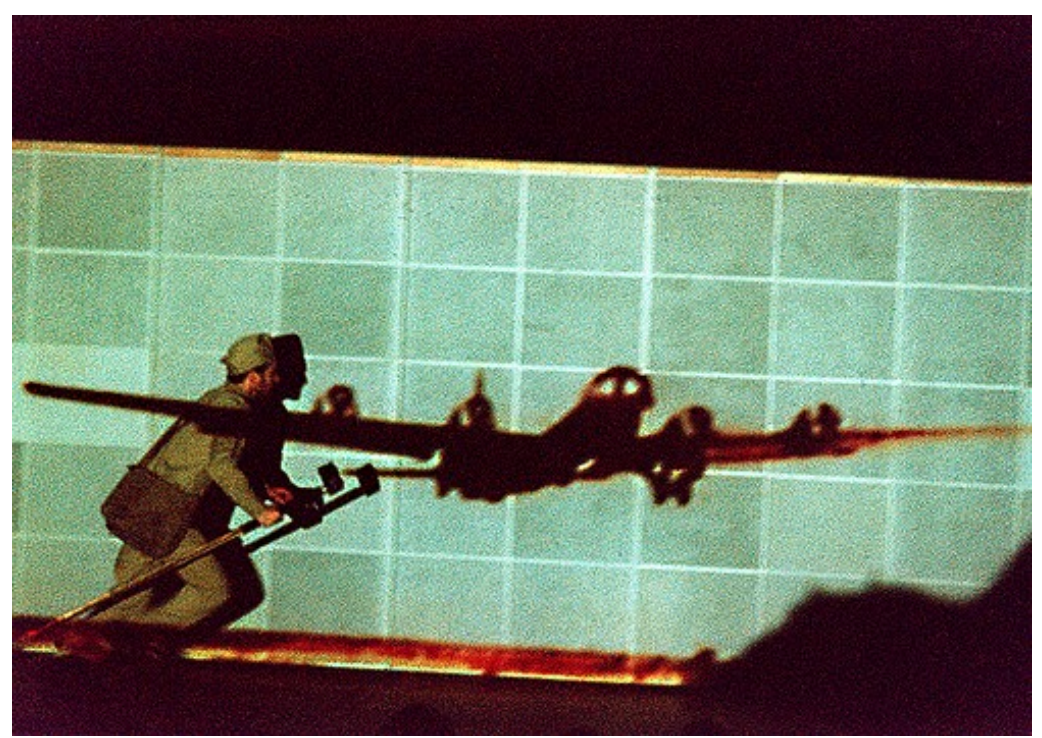

Fig.46 Cena de 'Os Sete Afluentes do Rio Ota', montagem brasileira com direcão de Monique Gardenberg

A memória é elemento sempre presente na poética lepagiana. Em seus espetáculos solo é a memória pessoal do encenador que inspira muitas das cenas durante o processo criativo. Mas uma espécie de memória coletiva também tem seu papel, em sua poética: é o caso dos espetáculos que se utilizam de fatos ou personagens históricos e nesses casos a inclusão do uso de linguagens do cinema ou do vídeo se torna sua característica especial.

Assim, encontramos na Trilogia dos Dragrões um fundo regional que refere-se as transformações ocorridas em uma rua específica da cidade de Quebec, além das referências ao ataque a Hiroshima, a filosofia de Mao Tsé-Tung, ao mito do Deus 
Kamikasi e aos pilotos suicídas, de mesmo nome. Em Vinci, assistimos ao encontro entre a memória pessoal de Lepage (habitada pela perda, então recente, de um amigo seu) com a memória coletiva, trazida à cena pela obra do artista renascentista Leonardo da Vinci.

Este encontro se repete em Agulhas e ópio em que cenas de artistas mundialmente conhecidos, como o francês Jean-Cocteau e o norte-americano Miles Davis são intercaladas com cenas protagonizadas pelo próprio Lepage, assumidamente chamado de Robert. Em Elsinore, é o texto mais conhecido de Shakespeare que garante a mobilidade da encenação, tornada solo: o conhecimento da trama facilita o estabelecimento das convenções cínicas que transformam uma personagem em outra, com muita simplicidade.

Em Geometria dos Milagres, é a vez de Frank Lloyd Wright e Gurdjieff emprestarem suas filosofias à arte lepagiana que traz à cena outras personagens reais extraídas da história dos mestres, para dar voz as temáticas da coletividade, da criação artística, da formação integral do indivíduo.

Em A Face Oculta da Lua, talvez o mais autobiográfico de seus espetáculos, é Lepage, na pele de Philippe, que apresenta diversos fatos ocorridos em suas relações familiares, ou desenvolvidos dramaturgicamente, a partir de sensações suas, conseqüentes daquelas relações. Paralelamente, a corrida espacial entre a antiga União Soviética e os Estados Unidos da América é abordada, sugerindo uma série de links no mosaico espetacular que se formula em cena.

Esta poética da memória, servindo-se de fatos ou personagens de conhecimento universal, convida o espectador a remeter-se a sua própria memória, na co-criação espetacular, estabelecendo os elos entre as personagens e fatos apresentados, através da ativação de sua própria bagagem cultural acerca deles.

Os fatos históricos, intrinsecamente ligados a personagens fictícios (muitas vezes criados a partir da bagagem pessoal do próprio encenador ou dos atores), formulam uma terceira memória, que revelando a trajetória das personagens fictícias, traz o histórico para um plano bastante pessoal: é a lembrança destes fatos ou as consequências na vida pessoal por eles provocadas nestas personagens criadas para a ficção que são exploradas pela trama espetacular.

As personagens históricas, através da recriação, pela ótica lepagiana, de sua 
memória ou de sua trajetória pessoal, são ou contrapostas a personagens fictícias que passam por questionamentos tangenciados a elas, ou apresentadas dentro de um recorte bastante específico que possibilita o questionamento abordado pelo espetáculo.

Assim, a memória na obra lepagiana é um dos pontos de partida do processo criativo e vai se fazer presente em cada recepção espetacular, ativada pela subjetividade de cada espectador que a ela recorre na identificação daquilo que é extraído da realidade universalmente conhecida.

A estética audiovisual de Lepage inclue diferentes tipos de imagens e muitos meios de comunicação, que são camadas da história da imagem (uma vez que temos o teatro de sombras até o teatro de imagens feitas, passando pelo vídeo). Sobre a relação que existe entre estas técnicas de imagem e a cena, Lepage afirma em entrevista a Ludovic Fouquet, em 3 de junho de 1997, que:

Eu sempre comparo o uso de vídeo a todas as técnicas chinesas de sombra, que existem a milênios. Esta 'tecnologia' é uma lanterna, ou luz elétrica, e um tema que vem a interromper a luz para criar uma poesia visual ou linguagem visual. Esta 'tecnologia' é aceite pelo público, pois ela sabe é feita, todo o mundo já brincou com a sua própria sombra. (BARONE, 2007, p.153)

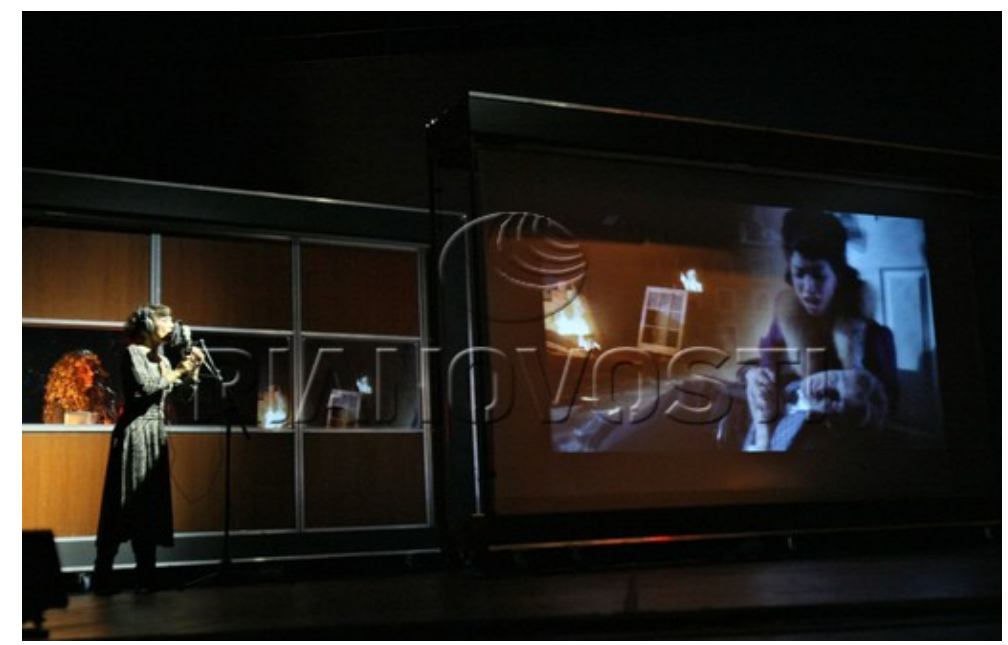

Fig.47 Cena de Lipsink, direção de Robert Lepage

Na década de sessenta, setenta e início dos anos oitenta, as projeções (vídeo, slides, multimídia) não eram conhecidas. As pessoas tinham televisão, mas ninguém sabia como ela funcionava. Foi muito estranho utilizar essas tecnologias no palco, 
porque os espectadores ficavam maravilhados ou subjugados a elas, eles não eram suficientemente sensíveis à poesia ou narrativa.

Tenho a impressão de que as coisas mudaram, agora podemos colocar o vídeo no palco: as pessoas têm uma câmera em casa. Estas tecnologias são desmistificadas, tornaram-se as sombras chinesas. As pessoas aceitam agora embarcar em uma viagem de poesia, quando se utilizam as possibilidades do vídeo. Fazemos filmes há décadas e somente hoje aceitamos mais naturalmente esta linguagem.

Em Elsenore e Os Sete afluentes do Rio Ota, as telas estão incorporadas à cenografia, caracterizadas por uma verdadeira ambivalência (suportes de imagens, elementos do dispositivo, objeto-decoração) e uma alta mobilidade. Assim vemos as memórias sendo garimpadas e as tramas costuradas aos recursos audiovisuais de forma que as imagens tecnológicas oferecem uma viagem à memória.

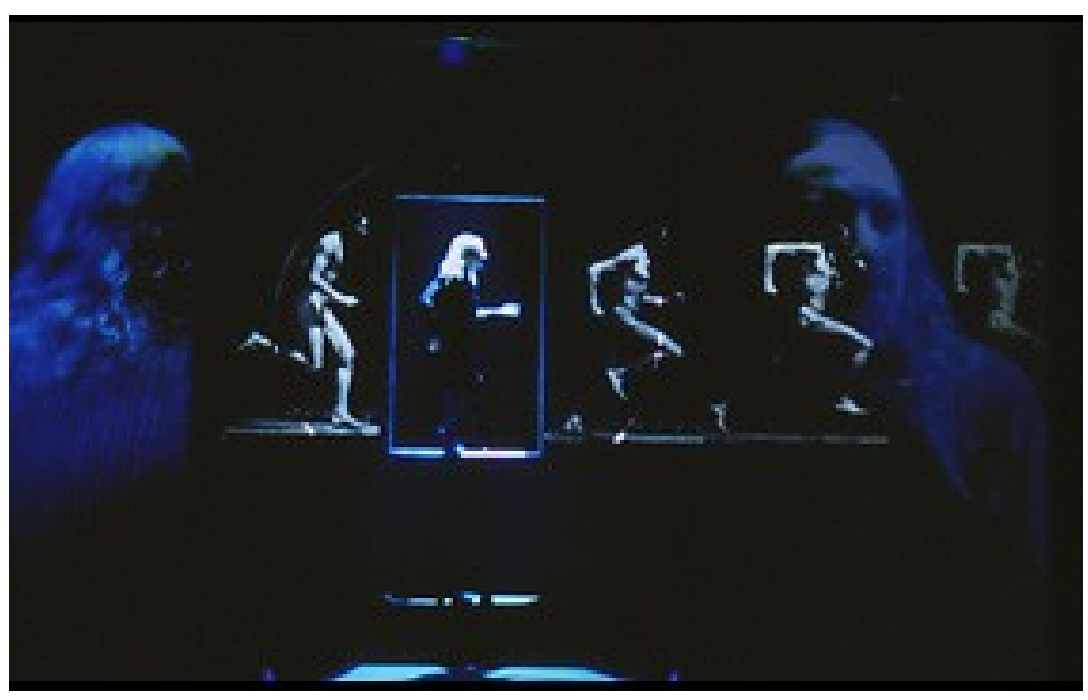

Fig.48 Cena de Elsenor, de Robert Lepage

Sobre seu relacionamento com o resto do conjunto da cena, Lepage afirma que o ator deve produzir duas impressões de si mesmo. Deve ser um ator 'cênico' e também é preciso ser 'tela', ou seja, ele deve estar ciente de sua sombra, tanto quanto a sua presença física, precisa construir sua imagem bidimensional (Fig.48). É o encontro destas duas maneiras de se expressar que faz a originalidade destes dois espetáculos. Às vezes não é muito feliz, às vezes é bem sucedido, às vezes algumas coisas surpreendem.

Em Elsenor há um momento que, enquanto ator, acho interessante: estou literalmente na beirada, na borda de um painel do palco. Eu estou na porta e falando com Horácio, o público está de um lado, por exemplo, na minha 
direita, e a câmera de outro. O espectador vê duas imagens, tem duas impressões: uma que é bidimensional, gigante de face (ele vê a minha rosto) e outra que é uma silhueta. Estas duas personagens estão sentadas, como interligados, como se um contivesse o outro e eu tenho que encenar as duas coisas ao mesmo tempo, para a câmera (e, portanto, para o espectador) e para a sala, e também para o espectador, mais diretamente. É muito ímpar. Acho que aqui, há uma abertura na reunião desses dois meios de comunicação social, com toda a sua complexidade e com tudo o que a sua magia. (...) Há algo de muito teatral. A primeira vez que eu vi os bailarinos de Butô, Sankai Juku, por exemplo, uma coisa me surpreendeu (...) um rapaz estava vestido como um soldado japonês, totalmente revestido com pó de arroz, ele estava no palco, ele se mexia. De repente, ele se moveu a uma velocidade louca, tão rápido que o pó permaneceu no local e tudo desapareceu. É um pouco como uma extensão da ideia da sombra. O teatro começa em uma direção e acendemos uma chama. Um contador de histórias se levanta e começa a dançar, ele conta uma história. Atrás dele, nas paredes da pedreira, a sua sombra é projetada, o seu duplo. Um contador de histórias nunca está sozinho, em princípio, e sua sombra, sua imagem bidimensional pode dizer muitas outras coisas. Para mim é um elemento que está presente no cinema desde o início. Então a cena evolui, a tecnologia evolui e no século XX, começamos a apagar as sombras. É o naturalismo que conduz a isso e mata o drama. O foco ainda está em nós e em doze sombras. Quando Josef Svoboda criou seu andar veneziano, com ripas de metal inclinadas, seguindo o ângulo do projetor os personagens não tinham mais sombra; ela é projetada no palco. Com Sankai Juku, eu entendi a ideia de sombra, essa espécie de vestígio. (BARONE, 2007, p.153)

Em outro espetáculo que fala das sombras, Dumb Type, eles assumiram o seguinte: em vez de fazer um black out, eles fizeram um white out. De repente, não havia mais sombras e sua ausência nos atormenta. Três macas entram, vemos três sombras no chão, e nós percebemos que esses são os personagens estendidos sobre as macas de vidro. Isso muda completamente a nossa relação com a ideia de vivos e mortos.

Em geral, parece que em Rio Ota a tecnologia tem, em uma narrativa que the é própria, o discurso das memórias no lugar dos personagens para evocar a experiência da bomba. Sobre esta memória da maior catástrofe tecnológica do século é representada pela tecnologia no teatro e Lepage conclui:

A imagem está lá por obrigação, pois Hiroshima tornou-se um evento fotográfico, talvez não fotográfico, mas o "fóton-gráfico". Há uma explosão, um enorme flash esmaga os homens e deixa nas paredes os traços de suas sombras. É realmente a idéia da foto cabine, do flash. O primeiro objeto que entra em cena é uma câmera fotográfica. Luke O'Connor, na primeira cena, não pode tirar qualquer foto do dia, sua entrada é recusada, ele retorna, então é noite, ele deve usar uma lâmpada. Há algo de indecente para um americano para colocar uma luz assim forte ou uma chama na frente do rosto de uma mulher que foi exposto à bomba. Luke é um fotógrafo e o trabalho que realiza é uma representação em miniatura do que os americanos fizeram em Hiroshima. (...) Estas imagens, que deixam muito 
espaço para a imaginação, a maior parte das vezes superpõem camadas de elementos visuais, bi ou tridimensional (sombras, elementos decorativos, atores reais). Tenho a impressão de que aquilo que eu, como encenador desejo em primeiro lugar, é criar imagens encarnadas, vivas, em volume, imagens artesanais e não jogadas em uma tela. Há uma coisa que me interessa no teatro, é a possibilidade de lentificar o tempo, ou acelerá-lo, ou apontar os eventos que temos e nos lembrar. É bom ter um personagem em tempo real, que faz qualquer ação, banal, mas devemos sentir, por detrás dele, o arrastar da sua sombra, o fantasma, a marcha lenta do seu ato, ou o momento da sua interrupção, mesmo se o ator tem de continuar a atuar. Isso me fascina muito. $O$ ator que interpreta na foto não tem nenhuma idéia de quando sua imagem será utilizada. Não é como nos filmes, onde você escolhe exatamente as imagens, há um lado aleatório que muda a relação da foto e do ator. (BARONE, 2007, p.153)

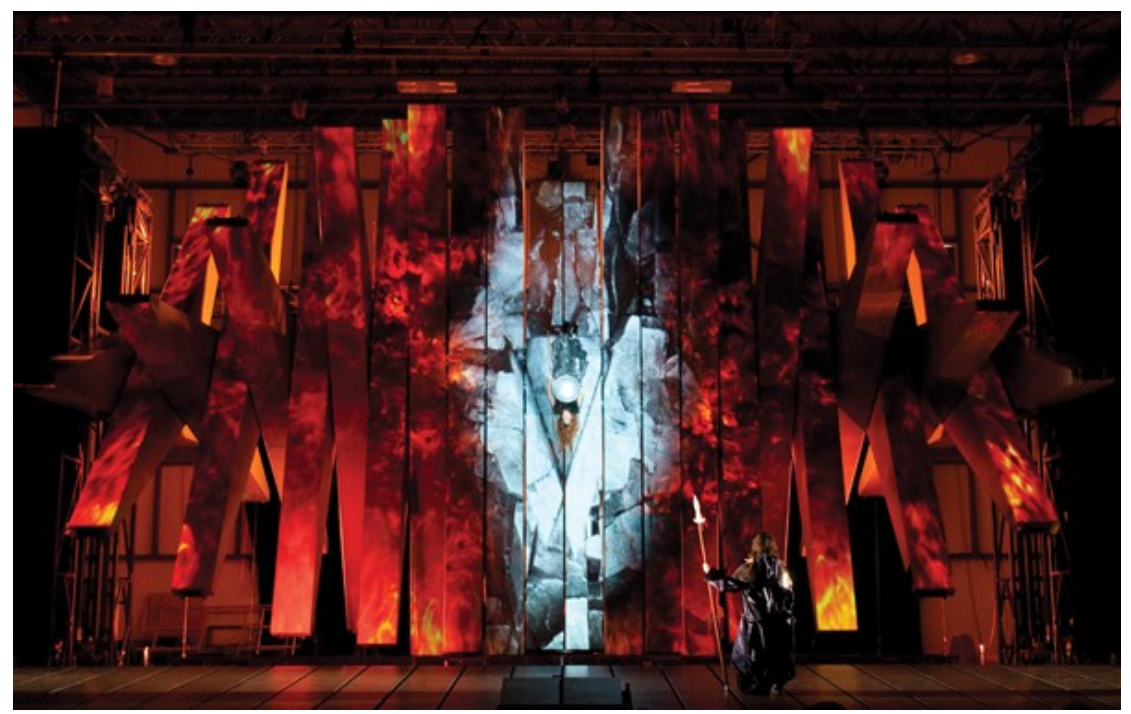

Fig.49 Cena da ópera Die Walküre, dirigido por Robert Lepage, que estreou em abril de 2010

Vemos que em 'Rio Ota' as propriedades da tela contaminam todo o sistema da narração. Tudo se torna tela, mesmo quando não existe fisicamente. 0 espelho torna-se uma tela, o cenário imaginário justapõe telas e assim o palco, há trezentos e cinqüenta figurantes que fazem coisas diferentes, a partir do momento que uma pessoa tem uma pequena moldura e a coloca em seu rosto, não olharemos nada mais que o seu rosto. Essa é a potência do quadro. $\mathrm{O}$ quadro estabelece uma fronteira entre teatro e realidade, mas isso não é o que materializa fronteiras ainda que ele seja transparente. 0 Wooster Group faz um trabalho interessante nesse sentido, mas não é incluído. Em Viena, eu vi seu show Fish Story, baseado na estética japonesa. Entre cenas, havia uma barra [grade] em que foi pendurada uma série de néon, tudo isso descia, tocava o palco, e mudava o cenário. Essa barrasubia novamente e foi o suficiente para dizer "A cortina caiu, mudamos o conjunto e agora nós partimos novamente". Foi suficiente apenas uma barra apoiada por dois fios. O Wooster Group começa sempre com um enorme cenário natural. Então ele remove elementos até que ele não faz mais do que duas ou três linhas. (BARONE, 2007, p.153)

Ludovic Fouquet indaga: Nos seus espetáculos, fotografias (com exceção de alguns registros) são revistas, ampliadas, reduzidas, coloridas. A imagem, seja capturada ao vivo ou não, é para você uma matéria móvel, animada, adaptáveis? O uso 

responde:

\begin{abstract}
Sim, o teatro é a mesma coisa, tudo deve ser ao vivo. Tem de haver mudanças. Isto coloca problemas, por exemplo, para informar um ator que está na frente da tela, você não pode fazê-lo de frente. Tudo combina para tornar o relacionamento "ator-tela" difícil. Em Elseneur, no fim, há uma luta com espadas, ao longo de todo o espetáculo, havia muitas fotos de lugares, paisagens projetadas. Novamente, o que eu gosto é que a tela fica completamente nua. E a luz é tão forte na minha camisa branca, que minha camisa ilumina a tela. Existe um diálogo entre a tela e a impressão luminosa do ator na tela. Mas ela ainda é percebida pelas pessoas com quem trabalho no espetáculo como um erro, não como uma perversão interessante. A tela coloca o seguinte problema: sentimos-nos sempre na obrigação de preenchê-la. Através da integração de outros universos, como cinema e vídeo, temos a impressão de que se redefine um novo público, que tem tanto o espectador tradicional, o leitor e o espectador de cinema (capacitado a ler didascalies, a dar saltos no tempo, a sobrepor as informações). Em Rio Ota passamos sem cessar de um período a outro mas essa capacidade de saltar no tempo não foi uma escolha do espectador. Foi imposta a ele. Quando nós colocamos as sete caixas em uma ordem cronológica para a versão de Rio Ota em Quebec, nos permitimos que ele acompanhasse melhor. Quanto a essa "redefinição" do espectador, acho que o intervalo é uma parte importante. As pessoas se explicam a peça, passeiam, e depois voltam. $O$ teatro foi aprisionado no século XX em uma estrutura onde você não pode passear, voltar atrás, se explicar as coisas. (BARONE, 2007, p.153)
\end{abstract}

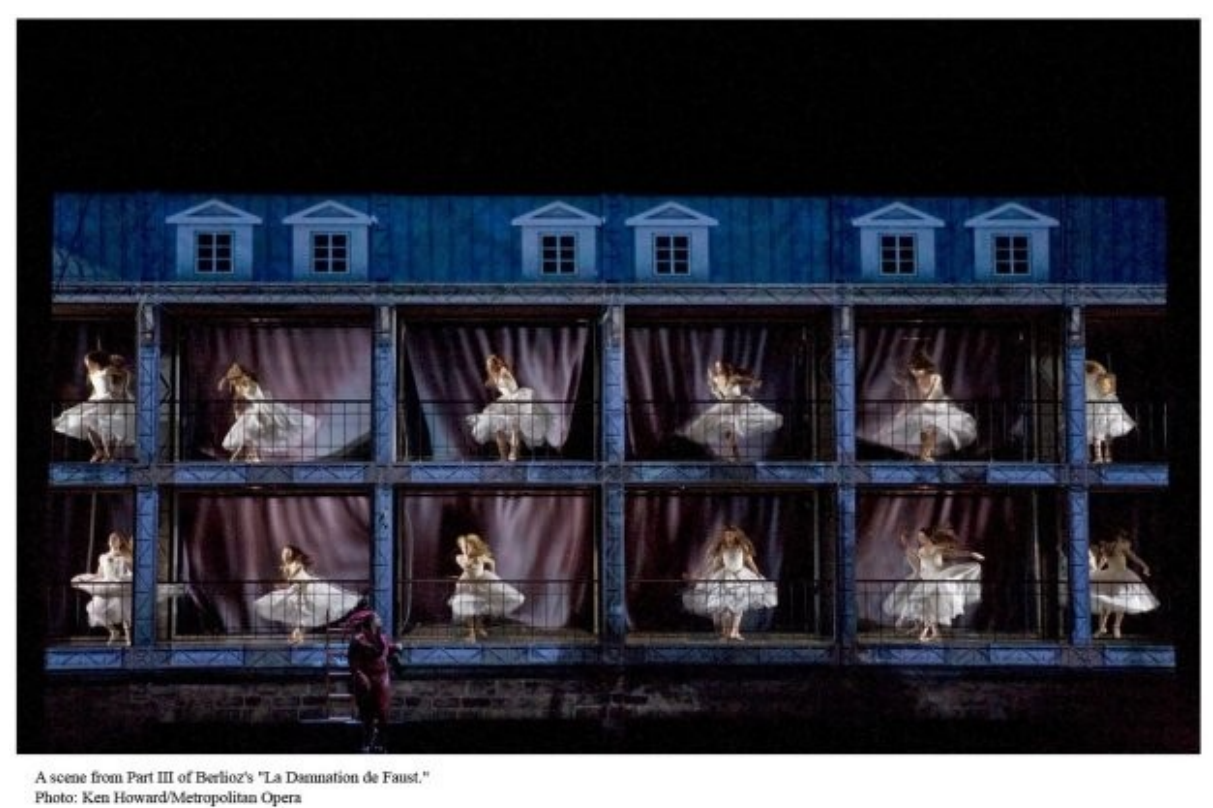

Fig.50 Cena de La Damnation de Faust, ópera de Hector Berlioz, dirigida por Robert Lepage, em 2010

Fouquet também indaga - integração de imagens e alterações visuais forçam o espectador a reconhecer a importância da convenção no teatro e a descobrir um raro prazer: o de contribuir para o processo de criação. Daqui resulta uma magia no trabalho. Estas obras dentro de outras obras são marcas do seu fazer teatral? 
Isto é importante porque se as pessoas não entendem como é que funciona, não há ilusão. Quando você vai para a Disneylândia, você olha para as coisas inimagináveis. Você vai embora e não para de dizer 'mas como é que eles fazem?' ou mesmo a Broadway, é soberbo mas dizemos 'eles têm dinheiro, eles têm máquinas, nós não sabemos como eles fazem, nós somos bestas, eles são inteligentes'. Isto não é para maravilhar com os efeitos, mas sobre a forma como eles são feitas. Penso, e é por isso que eu gosto de mostrar as cordas, o espectador deve se sentir inteligente. Então ele acha que ele pode criar com a gente. É preciso que o espectador em sua cadeira trabalhe, trabalhe. Acreditamos que o teatro é um lugar em que não se precisa trabalhar. Digo o contrário 'Venha, você vai trabalhar duro'. As pessoas querem trabalhar. Após um dia de trabalho, eles vão fazer ginástica ou outras atividades. Por quê? Devido a sua verdadeira energia criativa, que é uma energia biológica e não foi usada em seu local de trabalho. A mágica se dá pelo esforço mental, esforço físico que o espectador deve fazer para compreender. Qual diferença você faz entre meu trabalho no teatro e meu trabalho cinematográfico? Como me defino a relação com a imagem fílmica (cinema e teatro integrando uma projeção)? Fiz apenas dois filmes ${ }^{28}$. Acho que é difícil tirar conclusões. Após o segundo, eu descobri que os métodos são completamente diferentes. Nós não podemos contar a mesma história com duas mídias diferentes. $O$ espectador vem ao teatro para encontrar uma comunidade de artistas. E sua relação com o teatro é de ordem comunitária, ele irá vagar durante o intervalo com uma comunidade de pessoas. 0 espetáculo vai ser bom ou ruim, o público vai estar quente ou não. O filme é exatamente o oposto. A sala está cheia ou vazia, isso nada faz para mudar o que vemos. É um assunto íntimo entre o espectador e a imagem da personagem que ele vê na tela: ele não se identifica com o ator, mas com o personagem, o que é muito diferente. No teatro, os personagens nos afetam a partir de uma série de outras propostas. Enquanto o filme é realmente uma relação íntima. E esta relação é facilmente quebrada, se o filme é interrompido, se houver uma pane de som. No teatro, podemos retomar, as pessoas aplaudem para ajudar, elas fornecem um tipo de apoio. Francis Leclerc fez uma adaptação de Rio Ota para a televisão e foi preciso esclarecer, fazer escolhas radicais e procurar o que era o personagem principal de cada um dos atos. Vendo a edição, achei que deveria refazer todo o espetáculo, e tudo foi refeito a partir dessa primeira clareada. Isto rendeu coisas surpreendentes. A ideia de ter uma menina, no início, e que essa menina fosse Hanako, foi encontrada para o filme ${ }^{29}$. Eu vejo isso como um bom exemplo da possibilidade de rodar um filme baseado em uma peça, e de reescrever essa peça para o futuro. Eu poderia fazer outro filme sobre Rio Ota, embora houvesse agora sete vezes superiores aos 7 minutos porque agora há um rico campo para a linguagem do cinema. (BARONE, 2007, p.153)

\section{Sobre o projeto La Caserne ${ }^{30}$, Lepage afirma:}

\footnotetext{
${ }^{28}$ Le Confessionel, que teve lugar no primeiro Festival de Cinema de Cannes 1995, O Polígrafo, adaptação cinematográfica da peça, criada em 1989, várias vezes premiado. Le Polygraphe saia em Quebec, no momento da entrevista.

${ }^{29}$ Ele está incluído na versão teatral de Quebec.

${ }^{30}$ La Caserne, depois de muitas vicissitudes políticas e econômicas, foi inaugurada em 2 de Junho de 1997 na cidade de Quebec. Robert Lepage cria assimsua base, lugar de pesquisas, teatro, cinema e estúdio de criação de imagens (cada criador tem uma oficina-estúdio). Um lugar verdadeiramente versátil, como seu criador, um lugar, antes de tudo centrado no teatro, com uma abertura simbólica das
} 
Este é essencialmente um instrumento de exploração, experimentação, criação, produção, e não um local de distribuição. Vamos mostrar algumas vezes nosso trabalho, mas não se trata apenas de um teatro. $O$ nosso primeiro objetivo era ter um lugar para estar em casa. A Caserne foi projetada de uma maneira particular, sem a hierarquia que é utilizada freqüentemente em nossos teatros, e que faz com que o palco, administração, as oficinas os cenários, as salas de ensaio sejam separadas. Aqui, todos os interessados (contadores de histórias, pintores, atores, etc.) desenvolvem seu objeto teatral, toda a gente tem uma porta ou uma janela com vista para o corredor. Na fase de pesquisa, podem se consultar diretamente: a energia e a criatividade se cruzam. Aí está um conceito de teatro laboratório. No que diz respeito ao desenvolvimento, que será equipada com salas edição, gravação (...) é um centro de teatro, mas também cinema, um set de filmagem, ao mesmo tempo em que é um palco. Tecnicamente, trata-se de dois mundos, e decidimos estabelecer encontros entre eles em todos os níveis: na estética, técnica (...) o teatro e o cinema de amanhã, são duas formas de expressão que serão misturados, o que já começou. Portanto, em Elseneur e em Rio Ota há esta primeira união. (BARONE, 2007, p.153)

No momento Lepage ainda continua ser o amigo da tecnologia na cena teatral, e soma várias montagens onde os recursos das imagens tecnológicas é cada vez mais desenvolvida, utilizando cenários-telas mutáveis, telas de LEDs e muitos recursos desenvolvidos especialmente por sua equipe. Destaco as montagens 'Le projet Andersen', de 2008 (Fig.49), KA (Cirque du Soleil), de 2009, e as óperas 'Die Walküre', de 2010 (Fig. 47), 'La Damnation de Faust', de 2010 (Fig.48) e 'Lipsink', de 2008 (Fig.42 e 45).

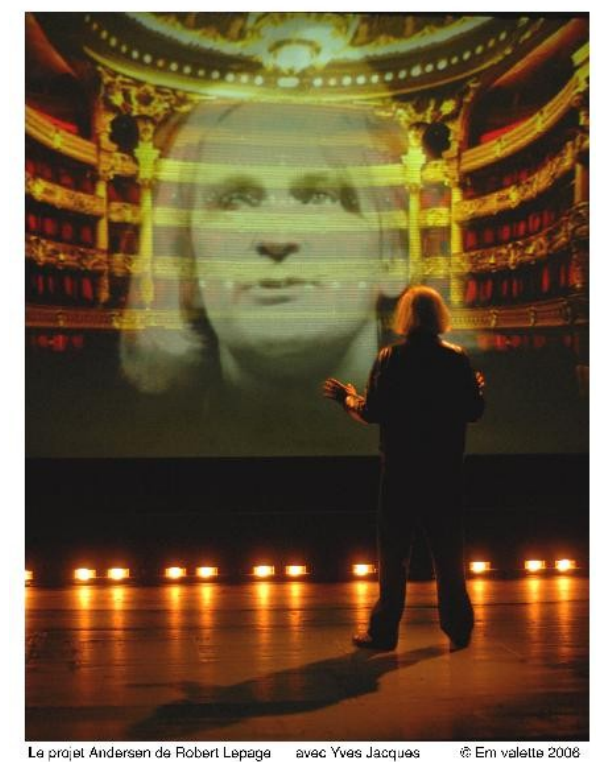

Fig.51 Cena de 'Le projet Andersen', direção de Robert Lepage, de 2008

cenasde rua: uma visão de fora, sendo que a cortina de ferro está aberta, o inverso dessa antiga caserna de bombeiros, é uma grande caixa preta cujo centro é a cena. 
Em todas elas vimos que mais que deslumbramento tecnológico, Lepage utiliza esses recursos das tecnologias da imagem como suportes essenciais na suas narrativas, e prova que a junção entre as linguagens cinematográficas e cênicas podem e devem criar novas e mágicas possibilidades.

\subsection{Experiências do grupo Cena 11 (Brasil)}

No Brasil, destaco o grupo de dança contemporânea Cena 11, que além da qualidade de seus trabalhos, mantém uma sequenciada e evoluída pesquisa entre dança, performance e tecnologia. A tecnologia em seus projetos reune teoria e prática, e incluindo ações que contribuem para a formação e profissionalização do ambiente onde estão inseridos. Os sistemas de interação entre corpo e tecnologia vem se sofisticando. Jamais empregada como alegoria, nem é tratada como um recurso para produzir efeitos especiais na coreografia ou na imagem do dançarino.

Ela atua, por exemplo, no sentido de produzir estados de inevitabilidade e prontidão nos corpos. O design do movimento acontece através de um método de controle para o não-controle. Os sistemas de interação entre corpo e modificação do ambiente utilizam sensores, câmeras, acelerômetros, robôs, programas de detecção de padrão e vídeos.

Nesse contexto o público não é apenas testemunha, ele é cúmplice e sua participação é necessária para a realização dos roteiros coreográficos no palco. Entre os elementos que vem constituindo o método que o Cena 11 vem criando ao longo dos pelo menos 10 anos, está a questão da inevitabilidade.

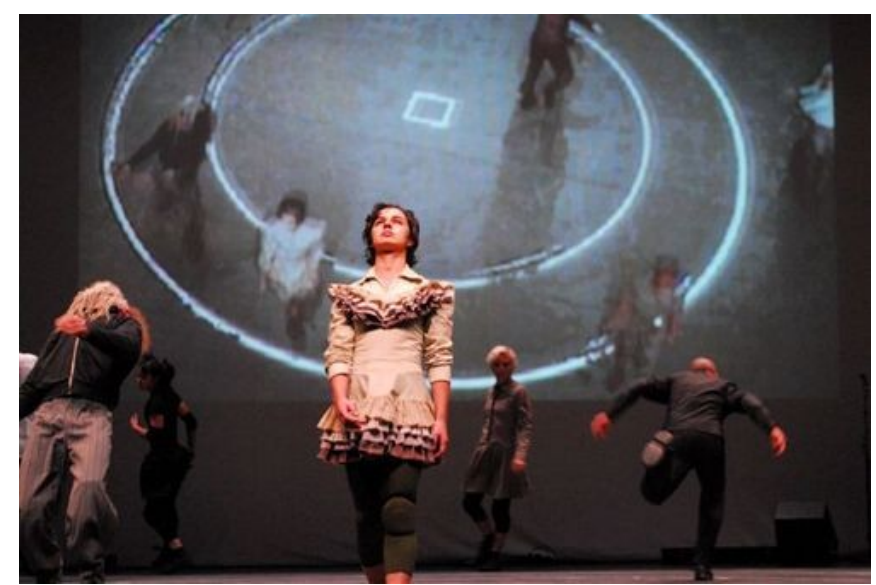

Fig.52 Cena do espetáculo 'PFdRSFi - Pequenas frestas de ficção sobre realidade insistente', de 2007 
A utilização de imagens e do vídeo é um interesse antigo e recorrente na trajetória artística dessa companhia. Desde 1994, no espetáculo 'Respostas sobre dor', esse recurso e linguagem vem constituindo cenas, fazendo ligações, brincando com memória e ausência, experimentando outro ambiente para o movimento.

Em 'PFdFSRi' passaram a fazer parte de um sistema mais complexo em que movimento, programação computacional e vídeo atuam co-dependentemente para produzir imagens tecnológicas que além de interativas, processam avatares dos bailarinos e também do publico, que também é incluso nas transmissões em tempo real (Fig.50).

A companhia assume publicamente ser parte de uma esfera específica da dança na qual a tecnologia já está incorporada e é entendida como possibilidade para o universo artístico. Assume, portanto, a tecnologia como marca registrada de sua arte como também acompanha a própria ideia de arte para o grupo.

\subsection{Outras experiências brasileiras}

Alguns artistas brasileiros têm se debruçado em experiências em imagens tecnológicas como função de negociar novas temporalidades e realidades. O Grupo Teatro para Alguém, em 2008, fez um espetáculo teatral transmitido pela internet. Bastando acessar o site do grupo para acompanhar a montagem.

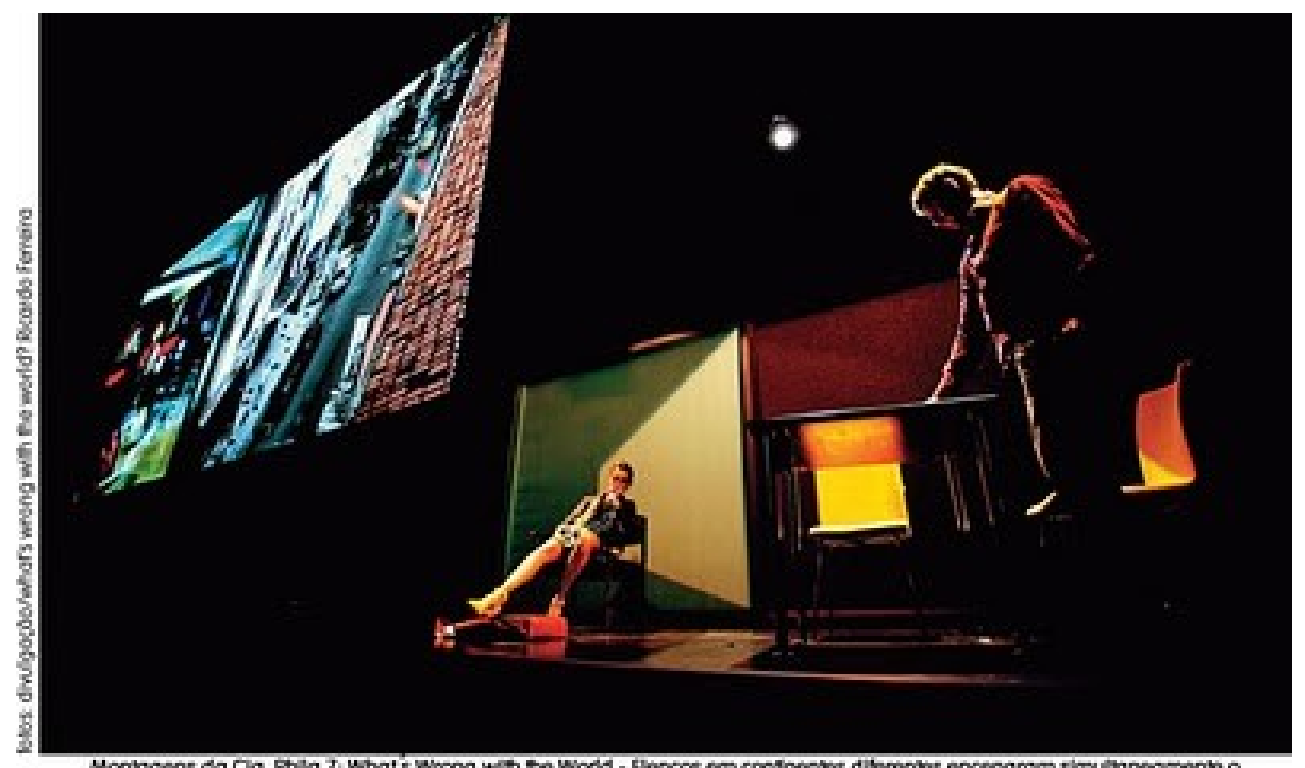

twesmo kxto e intorogltam uns com os ouros por imagets.

Fig.53 Montagem da Cia. Phila 7: What's wrong with the world - elencos em continentes diferentes encenaram simultaneamente o mesmo texto e interagiram uns com os outros por imagens 
Tarefa parecida fez também o grupo Teatro oficina com a transmissão em tempo real de sua epopéia 'Os Sertões' no site UOL. Porém nao se trata de uma mera transmissão do espetáculo, e sim de outra obra já que as imagens captadas por várias câmeras ao vivo, tem tom bastante intruso na encenação e as imagens são dirigidas e editadas em tempo real e transmitidas pela internet.

Os primeiros a misturar artes cênicas com tecnologia por aqui foram os integrantes da Cia. Phila7 (Fig.51). Capitaneada pelo diretor Rubens Velloso ${ }^{31}$, a Phila 7 tem desenvolvido um trabalho notável não somente sobre o palco, mas também no que se refere à pesquisa e ao embasamento conceitual dos seus trabalhos. Eles amadureceram muito a visão sobre a união entre artes cênicas e tecnologia nos últimos tempos com a série Play on Earth.

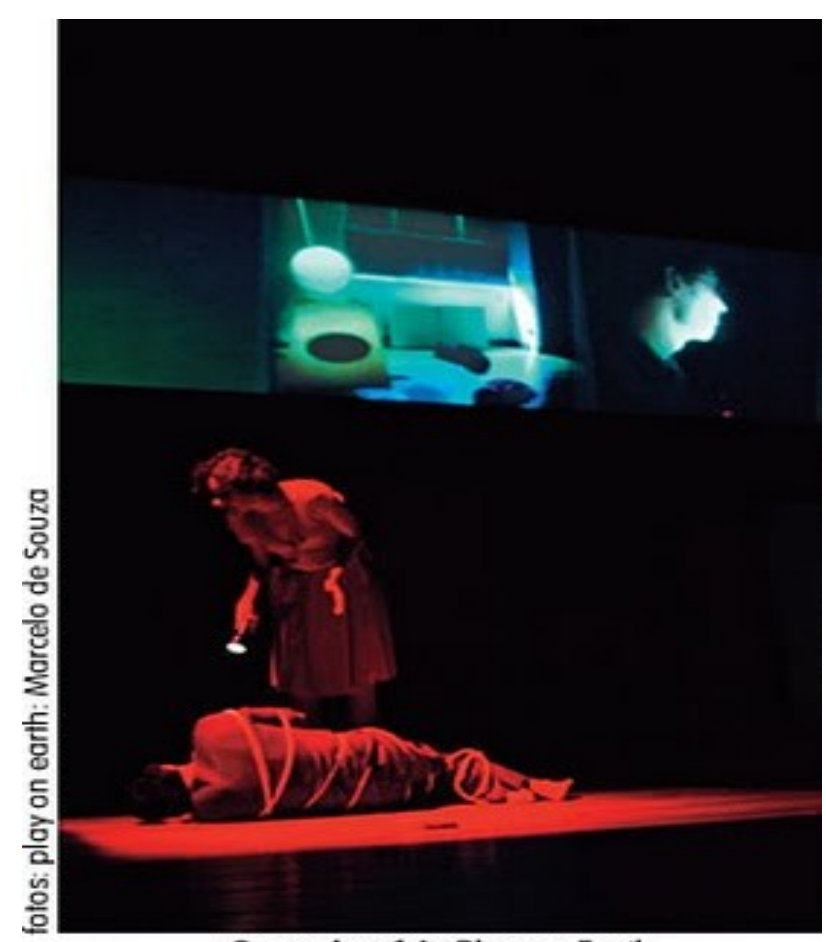

Fig.54 Cena da série Play on Earth

Cena da série Play on Earth

O grupo se formou em 2005, porém, foi no ano seguinte, com o primeiro espetáculo, que ele usou a internet para a criação e apresentação de uma peça. Nesta primeira experiência, três elencos em três continentes encenaram simultaneamente o mesmo texto. Conta o diretor Rubens Velloso

\footnotetext{
${ }^{31}$ Todas informações referente ao trabalho da Cia. Phila 7 e falas do diretor Rubens Velloso foram obtidas em WWW.gag.art.br/phila_7
} 
As companhias atuavam ao vivo, com público presencial, mas também com recortes estabelecidos com câmeras que mandavam imagens de um lugar para o outro. E isso era construído com um roteiro, como uma coreografia. (VELLOSO)

Além do paulistano Phila 7, o Station House Opera, em New Castle, na Inglaterra, e a Cia. Theatreworks, em Cingapura, participaram do espetáculo. O que nao só aparece como uma rica experiência com o tempo e claro com questões de espacialidade também. A montagem de What's Wrong with the World, segunda peça da série Play on Earth, foi feita em abril de 2008, no Rio de Janeiro e em Londres.

Não eram imagens pré-gravadas. O atuante que estava em Londres realmente estava naquela hora ali. Então, ele chegava em termos de imagem, mas a percepção para o público e para nós artistas era de uma presença clara. Ele estava lá. A gente apenas usava um suporte digital para trazer o sujeito de lá para cá. (VELLOSO)

Toda essa mistura de meios e formas, entretanto, deixa uma dúvida para quem assiste e até mesmo para quem faz. Será que esses espetáculos podem ser realmente considerados teatro? Para o grupo Phila 7, não. Comenta o pesquisador sobre a forte teatralidade contida.

Sinceramente, os experimentos contemporâneos não podem ser chamados com tanta certeza de teatro, videoarte ou performance. São obras cênicas que descendem da performance, do vídeo, do cinema, dos games, dos remixes, mas se articulam de maneira a produzir algo que, para mim, ainda não tem um nome. (VELLOSO)

Para transformar em realidade esses espetáculos, os idealizadores também têm de deixar o teatro convencional de lado e precisam estudar novas formas de pensar. 0 diretor Araújo Vellos completa:

Temos de pensar sobre estas formas que não eram pensadas antes. Para desenvolver o olhar, você tem de buscar novas estruturas de entendimento. Não adianta pensar em teatro, em vídeo, em imagem, tudo separado. Você tem de entender quais são as relações novas, sensíveis e concretas dessas novas formas de aproximação para poder reciclar a forma de ver o mundo. (VELLOSO)

A cena teatral paulista nos anos 2000 tem dado várias experiências em que as imagens tecnológicas vêm para ajudar as narrativas convocando a linguagem videográfica para operar trechos de memória, num jogo de tempo entre memória e 
inconsciente. Em 2009, os espetáculos 'Nu de mim mesmo', de Jeferson Miranda, 'Não sobre o amor', de Felipe Hirsh, e 'Entre o Céu e a Terra', de Sérgio de Carvalho, flertaram vídeo como viagem por tempo-espaço.

Hirsh, 36, que testou a alquimia entre teatro e vídeo pela primeira vez em 'Juventude' (1998) e volta a fazê-lo em 'Não sobre o amor' afirma que a projeção de imagens ou textos, em seus trabalhos, tem por intuito levar a ideia a outros lugares, intensificar o poder que a gente tem de decupá-la e traduzi-la. Mas não acho que usar vídeo dê mais liberdade para viajar por tempo e espaço. Esses cortes são absolutamente possíveis na própria dramaturgia. Já Sergio de Carvalho, 41, de 'Entre o céu e a Terra', diz buscar, com seu filme mudo comentado, a perturbação do cinema pelo teatro ' $O$ espectador está acostumado a se esquecer dentro da tela, entrar na ficção. Criamos um atrito, aí você assiste ao memso tempo de dentro e de fora, vê a construção do cinema e cria junto'. (NEVES, Folha S.Paulo, 18/2/2009)

Outro exemplo que cito como manipulação do tempo-memória sob os aspectos das imagens tecnológicas é o trabalho intitulado 'Festa de separação'(Fig.53), dirigido por Luiz Fernando Marques, mentor do Grupo XIX de Teatro. A montagem explora, além de lembranças e cartas pessoais, alguns vídeos do relacionamento de um casal que decide se separar, na vida real.

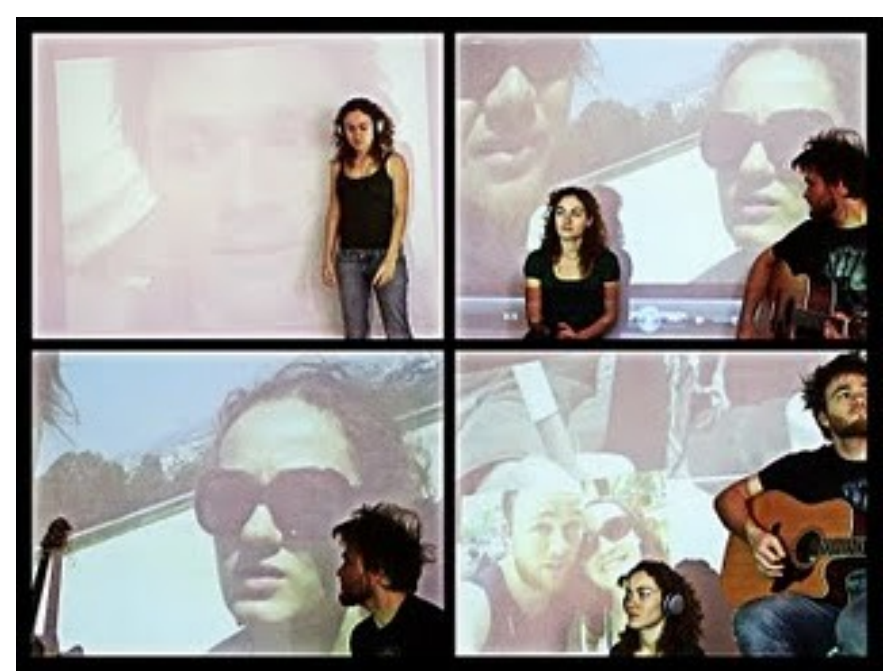

Fig.55 Cena de 'Festa de Separação', com direção de Luiz Fernando 'Fepa', em 2010

Depois de dez anos juntos o casal formado pelo músico Felipe Teixeira e a atriz Janaina Leite, que em parceria encenaram um trabalho sobre sua (real) separação. Aqui o vídeo é um franco recurso de recuperação de memórias, imagens, fotografias, documentos do passado em comum do casal que aos poucos são projetados no melhor estilo do Teatro Documentário. 
Com abordagem celebrativa o trabalho funde teatro, performance, música, vídeo e documentário, e as imagens tecnológicas aqui tem a missão de dar conta da exibição de um vasto material audiovisual íntimo, às vezes é um recurso cênico às vezes narrativo. O músico Felipe conta

Eu e a Jana já havíamos decidido usar os vídeos na peça. O Luiz Fernando ajudou a pensá-los cenicamente, enquanto o cineasta Evaldo Mocarzel capturou parte do material, pois a outra parte eu filmei e importei de arquivos pessoais. (SABATINELLI, 8/2010, p.20)

O diretor conta ainda que as imagens foram deixadas num DVD usado na peça e que não passou por nenhum tipo de autoração (criação de menus, atalhos e seleção de cenas). A informação chega a causar surpresa, afinal de contas, em determinado momento da peça, Janaina dialoga com o público e oferece à plateia quatro opções de vídeo, expostas em uma espécie de menu, e ela revela:

\footnotetext{
Aquele menu é falso! É uma imagem estática que dura os minutos necessários para a execução da cena, que tem essa interatividade com o público. É como uma faixa do DVD, apenas. A gente só tem o trabalho de mudá-la. As imagens de arcabolso memorial eram acessadas, porém trabalhadas por depoimentos, num claro resgate do tempo via imagens tecnológicas. (SABATINELLI, 8/2010, p.20)
}

\subsection{Experiências em 'Devorando Quixote'}

Dando continuidade a minha pesquisa aponto atividades pessoais como diretor e cenógrafo com uso de tecnologias da imagem. Em 2008, dirigi o espetáculo 'Devorando Quixote', com direção também de Márcio Pimentel, trabalho que aborda o mito do personagem de Miguel de Cervantes (Fig.56).

Com três telões em cena, oito câmeras e dois VJs operando as imagens junto aos atores, o trabalho imagético/tecnológico se desenvolveu em duas frentes, a manipulação de imagens pre gravadas e tomadas de imagens ao vivo e manipuladas em tempo real, sempre de forma diferente, mantendo características mais performativas, sem muita precisão ou obrigação com a repetição. 


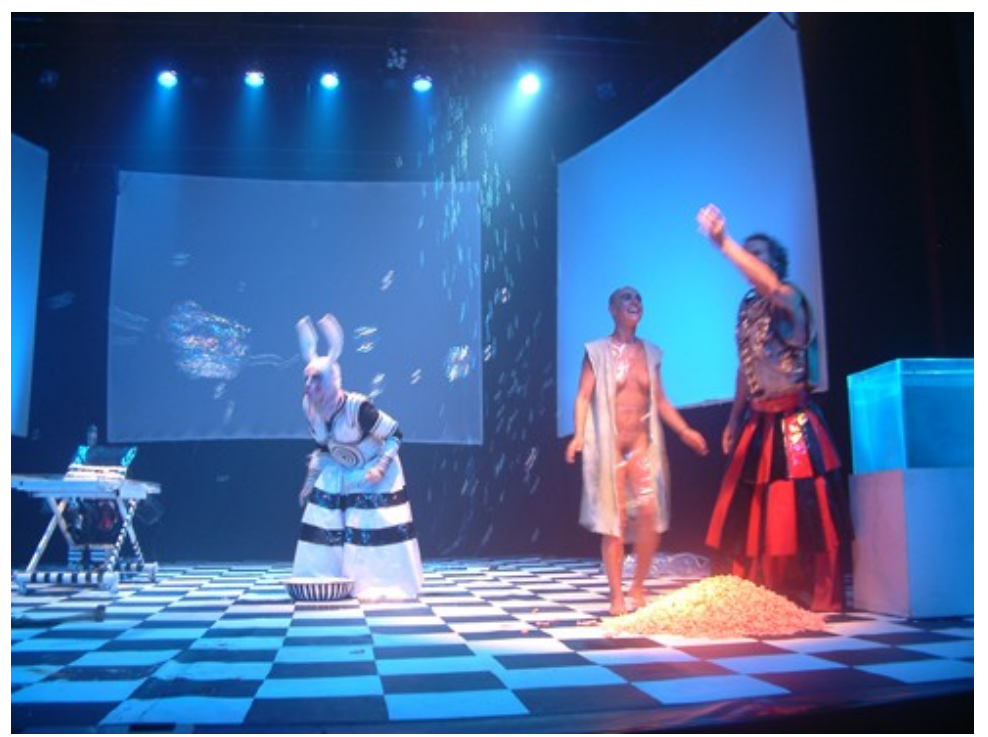

Fig.56 Cena de 'Devorando Quixote', direção de Marcelo Denny e Marcio Pimentel, em 2008

Em muitas cenas a ideia era alterar a noção de tempo, datas e horários que apareciam na tela e eram mudados sempre em oposição as marcações e tempos dos atuantes ao vivo. Enquanto a cena era feita em câmera lenta, o tempo na tela era acelerado e vice e versa.

Além disso, as memórias da vida da personagem principal eram frequentemente lançadas em cena, o que alterava também a 'interpretação' da personagem. A ideia da morte eminente do personagem era provocada com mutações de ritmo e tempo que o vídeo, via projeções, apontavam sob as variantes de cada dia, ou seja, as relações de tempo e ritmo da encenaçãoo eram utilizadas pelos recursos das imagens projetadas; e o papel da tecnologia como mantenedora da vida de pacientes terminais (situação da personagem principal) era também avaliada, ou seja, tempo e tecnologia também eram revistos dentro da narrativa do espetáculo.

\subsection{A imagem digital como tempo-memória}

Há muitas formas de perceber a presença de gesto, uma ação artística e seus contextos criativos, assim como há também muitas formas de falar do plano simbólico de uma imagem tecnológica em cena. As imagens tecnológicas em cena podem representar mundos invisíveis, redimensiona a imagem, coloca em choque o que acontece cenicamente, reposiciona o tempo ao vivo da cena ou da performance, 
criando uma fenda, uma possibilidade de deformação que representa a inscrição e a espiral do tempo.

A percepção do tempo é determinada por nossa capacidade de movimento em suas articulações espaço-temporais, diz respeito aqui a abordar aspectos existentes entre a imagem digital e a memória, na construção de uma qualidade de espaço sensório produzido pela deformação temporal de uma imagem, ou pelas chamadas anamorfoses cronotópicas.

O 'cronotopo' (tempo-espaço/espaço-tempo) ${ }^{32}$ é como um espaço de sensorialidade capaz de circunscrever o tempo e a memória. Assim percebemos que nas produções citados anteriormente, a presença de uma percepção temporal é inegável e ainda mais frequentemente compreendida como uma percepção de tempo e memória.

As anamorfoses cronotópicas produzidas pelas imagens tecnológicas em cena remetem à diferença de movimento produzida no interior de conjuntos contínuos de espaço-tempo, provocando a sensação de uma instantaneidade contínua na imagem digital. Nesse contexto, por meio de tais procedimentos, as anarmorfoses cronotópicas produzem uma espécie de dobra do tempo, que remete à suspensão do tempo. Essa dobra, impossível de ser visualizada na vida real ordena o espaço na suspensão de tempo. Ela é sentida como um lugar por onde se atravessa para um outro espaçotempo, como se fosse possível produzir por meio dela uma espécie de observação do tempo no espaço.

Assim ao recobrar tempos passados ou tempos futuros, e mesmo tempos ainda não vividos, imagens vindas do inconciente e da loucura, o tempo parace fluir de modo diferente que na imagem cinematográfica ou videográfica, pois aqui as imagens tecnológicas estão somadas a outras imagens e movimentos em tempo real, ou seja, essa soma entre a imagem tecnológica e a imagem real gera um outro modo de sentir e ler.

A imagem aqui muda de estatuto, adquire complexidade, não sendo mais concebida apenas como algo advindo da representação de mundos invisíveis mas

\footnotetext{
32 Termo que Mikhail Bakhtin utiliza para defenir o indissolúvel de tempo na literatura, especialmente no romance (MALDONADO, 2007, p.146)
} 
corresponde também à apresentação de uma experiencia física, como um tipo de vibração corpórea transmitida pela sensação física do movimento.

É como se a presença física do atuante, somada as imagens projetadas dentro do espetáculo, significasse uma soma e ao mesmo tempo o acréscimo do espectador que ao mesmo tempo que observa, tem sua atenção e sensibilidade alternada pelas imagens real e digital, ou real e virtual.

É quando é possível observar que há uma real apreensão, ou sensação reavivada da ação, pela capacidade que a imagem tecnológica tem de afetar contrastes de percepção. Nesse momento, a ação virtual e a ação física não apenas se tocam, mas se interligam simultaneamente.

\begin{abstract}
No mundo contemporâneo, permeado por fenômenos imagéticos extremamente caóticos produzidos pelos fluxos informacionais, refletimos muitas vezes como a imagem e a memória não mais pudessem se exprimir. Tamanho é o volume de informacnoes que agenciamos cotidianamente que temos dificuldades em discenir qualidades e diferenças que as regem. $O$ problema não é mais fazer com que a imagem ou a memória se exprimam, mas provocar-lhes uma outra instância de força que as atualize em nossa percepção. (MELLO, 2008, p.55)
\end{abstract}

Aponto que no embaralhamento de sentidos visuais e sonoros descontínuos, o olho de quem visita uma experiência cênica com imagens tecnológicas pode perceber ou buscar perceber um efeito de deslocamento entre uma imagem e outra, entre um som e outro, entre o deslocamento da imagem no som e entre o deslocamento do som na imagem, para que possa apreender um sentido poético total.

É nessa dimensão conceitual do tempo e memória das imagens tecnológicas que afirmo ser possível o uso dessas tecnologias como forma de apreensão sensível da realidade. Em sua capacidade de apreender o mundo como um conjunto de formas, revela alterações de movimento no esquema sensório da linguagem, ao mesmo tempo em que as imagens tecnológicas são, elas mesmas, expressas e reconduzidas a uma nova instância de força, tornando potente ela própria: memória e imagética contemporânea. 


\section{Capítulo 3}

A Imagem-Corpo: As tecnologias da imagem na construção de efeitos de presença do ator / performer

\subsection{Primeiras reflexões}

Qual o papel do corpo nas artes contemporâneas nos dias de hoje? Certamente essa questão esta na lista dos principais questionamentos da estética. As questões que envolvem o corpo e aquelas que de certa forma orbitam, como questões de sexualidade, gênero, posse, limites e poder, configuram uma constelação de temas e subdivisões que perpassam o corpo e seus limites, até questões onde a tecnologia cruza por matizes ainda mais complexas, como o cyber body e as questões do corpo pós humano.

É claro que as artes cênicas, em especial a performance e a dança, vão investigar de forma ostensiva essas relações do corpo com a tecnologia. Tentarei aplacar algumas relações possíveis entre as tecnologias da imagem e sua relação com o corpo dos atuantes, sejam atores, dançarinos ou performes; relações que podem mudar as expressões mais performativas em conjunto com as tecnologias que permitem um diálogo visando ampliar aproximações entre corpo e cena e também corpo e máquina.

O desenvolvimento humano sempre demandou a evolução dos meios de produção e comunicação obrigando cientistas, pensadores e artistas a acompanhar as modificações das necessidades do homem, sejam elas o aumento da produtividade, a confecção de novos meios de se vestir e interagir nas comunicações.

As vanguardas históricas sempre tiveram a evolução tecnológica em seu encalço, servindo-se dela à medida que se tornava disponível. Artistas visionários buscaram conectar-se às modificações sociais e transpassaram-nas em suas obras, mostrando que a arte, além de seu caráter utópico e sonhador, também é um discurso crítico da vida real, vejamos pelos futuristas e suas contestações revolucionárias, os dadaístas e suas visões sarcásticas, os surrealistas e seus mundos paralelos, até as primeiras manifestações contra a própria arte nos anos 60.

Uma das grandes questões neste período artístico dizia respeito à maneira como as tecnologias poderiam participar e modificar o campo criativo. Essas "novas" tecnologias apareceram como ferramentas capazes de produzir e transmitir conteúdos e 
linguagens artísticas, fixá-los em novos suportes e elevá-los a pontos antes inacessíveis. As evoluções tecnológicas trouxeram para as ultimas décadas múltiplos olhares a respeito do que conhecemos como cultura.

Numa dimensão mais contemporânea e mais adentro das possibilidades digitais pretendo refletir acerca da ampliação do entrelaçamento entre o humano e a máquina através das tele-tecnologias e da disseminação dos dispositivos e da lógica hipertextual que acabou por alcançar o próprio corpo, que é submetido a todo tipo de operações: modelizado por programas computacionais (no domínio do cinema e das experimentações artísticas); entregue ao jogo das aparências e da simulação das identidades nos chats e salas de conversação; conectado a próteses artificiais; vasculhado em seu interior - mas sem ser penetrado - pelas nanotecnologias ou pelos programas de realidade virtual, tornando lugar de implantes biotecnológicos; ou então movido e afetado à distância por meio dos dispositivos - técnicos e artísticos - que se servem da telepresença.

Poderíamos afirmar que, mais do que objeto de desejo (como comprovam todas as paixões eróticas que pululam na internet, das mais perversas às mais inocentes), o corpo aparece aí como um objeto de projeto - segundo a expressão do artista australiano Stelarc ${ }^{33}$.

Como em qualquer meio de expressão em que a tecnologia desempenha um papel importante, o trabalho mais dinâmico ocorre quando a tecnologia acompanha as visões dos artistas ou os artistas acompanham a tecnologia. (RUSH, 2006, p.186)

O que pretendemos demonstrar ao longo desta reflexão é que mesmo quando falamos do corpo e da sua hibridização, ou interação com a máquina, encontramos o vínculo entre o socius e a subjetividade, agora sob a forma de um corpo partilhado a distância. Desta maneira, consideramos que as metamorfoses sofridas pelo corpo, seja através do objeto artístico ou ainda pauta das experiências tecnológicas estão, antes de mais nada, imbricadas em estratos sócio-culturais, códigos culturais e fluxos de espaçotempo que além de modelizar o corpo metamodelizam a subjetividade contemporânea.

\footnotetext{
${ }^{33}$ Stelarc, artista, performer, cientista e pensador australiano conhecido por trabalhos na área de arte e tecnologia com destaque pelo pensamento uma nova relação entre corpo-tecnologia, psique-biologia, como ponto de contato com o pós-humano
} 
Nesse fluxo direciono minha reflexão às relações entre o corpo e a tecnologia nas artes cênicas, em especial as relações entre as imagens tecnológicas e o corpo, a presença e os efeitos de presença que essa mixagem podem obter. Num cruzamento entre as possibilidades entre o corpo do atuante e as imagens tecnológicas, avaliando trabalhos de artistas e grupos que utilizam as interfaces digitais para transcender o corpo em novas telas, poéticas, cenas, coreografias, movimentos e obtendo resultados que ainda hoje nos jogam em áreas movediças de percepção e novos paradigmas de se entender esses novos (não) limites do corpo junto as tecnologias da imagem.

\footnotetext{
O corpo humano sempre foi objeto do olhar e da criação artística. Neste século, mais acentuadamente neste final de século, quando nossos corpos atingem um nível de plasticidade extrema e de dissolução de suas fronteiras físicas, sensíveis, cognitivas, não é de se estranhar que o corpo tenha se tornado o grande tema, foco, representação, objeto performático e objeto simulado das artes. (SANTAELLA, 2002, p.204)
}

O corpo se transformou em suporte, instrumento, foco e emissor de informações, negando as convenções anteriores baseadas na pintura, música e literatura. A busca por mais liberdade de criação expandiu seus horizontes a ponto de avançar para além de sua pele e ocupar espaços fora de seu alcance físico por meio das novas possibilidades que as tecnologias ofereciam, aliadas à linguagem performática que expunha questões particulares dos performes, amplamente utilizadas por grupos como Wooster Group e artistas performáticos como Laurie Anderson e Robert Lepage.

O corpo passou a ser tudo que o representava, mudanças semelhantes aconteceram no campo da dança com as pesquisas de artistas como Merce Cunnighan, Pina Bausch e Trisha Brown, mesclando técnicas clássicas a danças populares, movimentos repetitivos e naturais, e da interação entre movimento/corpo e novas formas de tecnologias.

Devido às modificações no conceito de transmissão de mensagens durante as ultimas décadas, acentuadamente nos anos 80 e 90 por meio das mídias de massa (TV, cinema, telefone e internet), a transmissão de informações passou a ser desassociada de um suporte. Houve uma separação entre mensagem e suportes físicos que provocou uma modificação no modo de gerar, receber e apreender informação, ideias e conceitos.

A leitura de uma mensagem hoje pode ser feita em diversas camadas (estamos constantemente mergulhados num mar de áudios, textos, vídeos, fotos). Neste 
panorama, em que podemos produzir uma mensagem desprovida de um corpo, podemos produzir um corpo desassociado de mensagens. Um corpo que não carregue apenas significados prévios, históricos, mas um corpo que possua capacidade de relacionar, reagir e integrar-se aos ambientes que habita ou percorre.

Mais que transmitir informações e significados, um corpo que esteja disposto a mergulhar no espaço, aberto a receber estímulos, os processar de forma crítica e racional, codifica respostas e devolve ao ambiente sua contribuição alimentando assim um ciclo de informações ativa.

O corpo não é um lugar onde as informações que vem do mundo são processadas para serem depois devolvidas ao mundo. O corpo não é um meio por onde a informação simplesmente passa, pois toda informação que chega entra em negociação com as que já estão. O corpo é o resultado desses cruzamentos, e não um lugar onde as informações são apenas abrigadas. (GREINER, 2005, p. 130)

Nesse princípio retomo algumas experiências antigas, onde a presença da modificação do corpo por meios audiovisuais já era buscada por artistas, a seguir veremos os desdobramentos desse corpo junto a cada vez mais novas possibilidades da imagem, seja ela eletrônica ou digital. Para tanto essa nova tarefa exige do performer um cuidado maior do que o que o de simplesmente sincronizar suas ações com as seqüências programadas dos aparelhos e das imagens tecnológicas.

Ele deve analisar as reações que se passam em seu interior, os ecos que estes canais geram com as informações que ele já possui, assim como observa poeticamente David Rokeby ${ }^{34}$, citado por Diana Domingues em seu artigo 'Desafios da ciberarte: corpo acoplado e sentir ampliado':

Os artistas, em seus projetos, utilizam conhecimentos científicos e
provocam uma reação mais estreita da arte com os experimentos da ciência.
As produções não mais tratam somente de falar de forma metafórica sobre
as forcas vivas, vazios, mutações, regenerações, a dinâmica de corpos,
gerações de vida a partir da imaginação, em representação que beiram o
sonho, o delírio, a magia ou outro estado emocional. As produções
interativas usam estes conceitos como linguagem. Ao atuar de forma direta
com as tecnologias, conceitos científicos vão sendo acionados na obra-
sistema e os participantes da experiência agem em situações complexas
com interfaces, hardware e software especialmente preparados para
oferecer ao corpo um campo novo de experiências estéticas. Sinais captados

\footnotetext{
34 David Rokeby, artista canadense responsável por instalações interativas que envolvem o corpo humano e sistemas de percepção artificial. Seu trabalho inclui vídeos instalações, esculturas móveis e também performances exibidas em vários países da América, Europa e Ásia
} 
do ecossistema através de ruídos, vibrações, calor, fala, toques ou outro sinal são processados e contaminam-se e são devolvidos transformados. É como o eco sonoro do sino que vão até a floresta e retorna com qualidades contaminadas pelas qualidades da floresta. (ROKEBY apud SANTAELLA 2002, p.66)

Definitivamente o corpo hoje junto as imagens tecnológicas é um corpo performático e um corpo processador: recebe imagens, sons, texturas, cheiros. Os processa e os devolve, os torna parte de seus pensamentos e os mescla, transforma som em movimento, luz em ação, espaço em histórias; além disso o corpo somado as imagens tecnológicas transformam a informação em contato com outras, num processo de imput e output, qualidade que somente um corpo afetivo e sensível pode conter e processar e assim alcançando significados mais subjetivos e velados da alma.

Para entender os flertes entre atuante e tecnologia das imagens, me reporto agora, a algumas experiências num passado que já rascunhava o diálogo entre o corpo do atuante e as tecnologias das imagens, em que o jogo da presença e dos efeitos de presença já eram buscados com simples usos de projeções de luz e imagens com auxílio de espelhos e outras técnicas.

\subsection{A fantasmagoria, primórdios dos efeitos de presença}

Numa mistura de performance ao vivo, truques de imagens em espelhos, projeções, a fantasmagoria foi um tipo de espetáculo luminoso concebido por mágicos e cientistas no final do século XVIII. Seus primeiros representantes e mais conhecidos foram Paul Philidor ${ }^{35}$, Thomas William Robertson ${ }^{36}$ (Fig.55) e Étienne-Gaspard Robert $^{37}$. A exibição de fantasmagoria, usando a lanterna mágica, era uma forma mais elaborada de entretenimento visual: invocava o sobrenatural projetando imagens de espíritos dos mortos em misteriosos ambientes, com encenações complicadamente dirigidas.

\footnotetext{
${ }^{35}$ Paul Philidor artista do ilusionismo que iniciou a utilização de truques do gênero fantasmagoria

${ }^{36}$ Thomas Willian Robertson (1829-1871), dramaturgo irlandês que influenciou autores e inovou a direção de palco com produções teatrais em Londres na década de 1860

37 Étienne-Gaspard Robert (1763-1837), mais conhecido por 'Robertison', foi um proeminente ilusionista, mágico, físico e balonista belga e um influente colaborador da fantasmagoria
} 


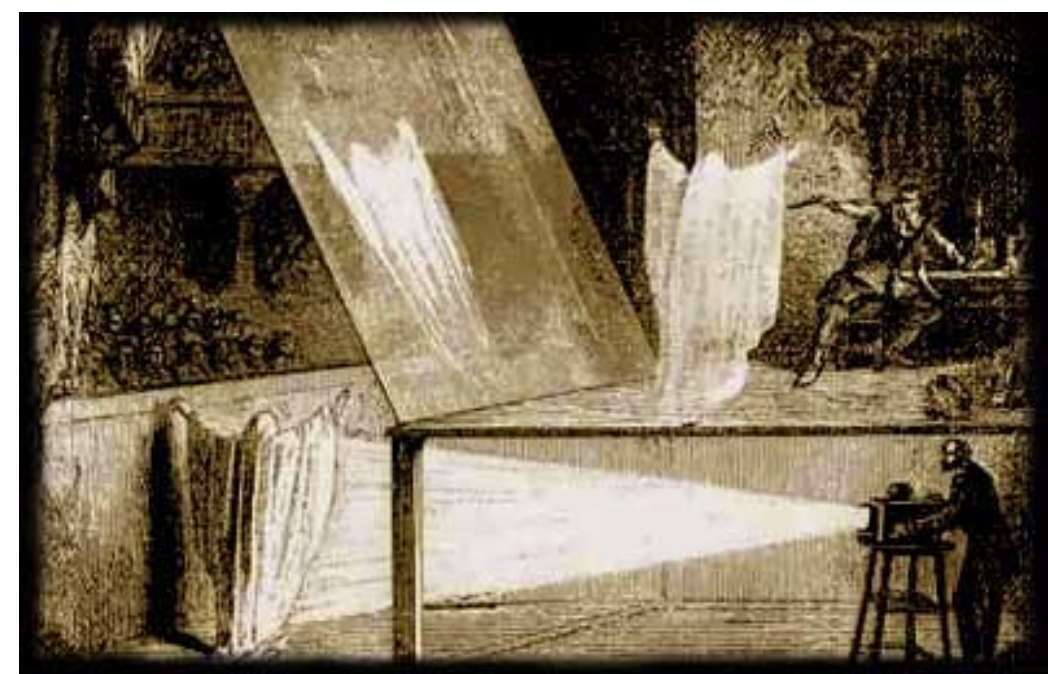

Fig.57 Espetáculo de fantasmagoria dirigido por Thomas William Robertson que projetava fantasmas com o uso de lanternas mágicas e espelhos.

A diferença destas exibições para as anteriores projeções de Lanterna Mágica é que com os aperfeiçoamentos da lanterna, se aprofundava a diegese ${ }^{38}$. O equipamento de projeção ficava escondido atrás da tela de forma que não fosse visto pelos espectadores, as projeções eram bem mais nítidas (graças a aperfeiçoamentos no tubo óptico da lanterna) e não mais apenas sobre as telas de pano tradicionais, mas sobre uma cortina de fumaça, criando um efeito mais realista, tridimensional.

A lanterna utilizada para esse tipo de exibição possuía rodas e se deslocava sobre trilhos para frente e para trás, proporcionando, além da já conhecida animação, o aumento ou diminuição das imagens, o que causava a impressão de que se moviam em direção à platéia. Além disso, ao início da exibição as luzes se apagavam, como parte da encenação planejada e, na maioria das vezes, as paredes da sala eram encortinadas de negro, possibilitando o escurecimento total da sala e acrescentando um tom fúnebre à encenação, reforçando, assim, as sensações dos espectadores (Fig. 56). Segundo os documentos da época, os espetáculos de fantasmagoria, ambiguamente, exploravam o gosto do público pelo obscurantismo, se esmerando na encenação para impressionar o público, ao mesmo tempo que tentavam combater a credulidade do povo em relação a feiticeiros e profetas.

\footnotetext{
${ }^{38}$ Conceito da narratologia, estudos literários, dramatúrgicos e do cinema que diz respeito à dimensão ficcional de uma narrativa. A diegese é a realidade própria na narrativa ('mundo ficcional', 'vida fictícia') à parte da realidade externa de quem lê (o chamado 'mundo real' ou 'vida real'). O tempo diegético e o espaço diegético são, assim, o tempo e o espaço que decorrem ou existem dentro da trama, com suas particularidades, limites e coerências determinadas pelo autor.
} 


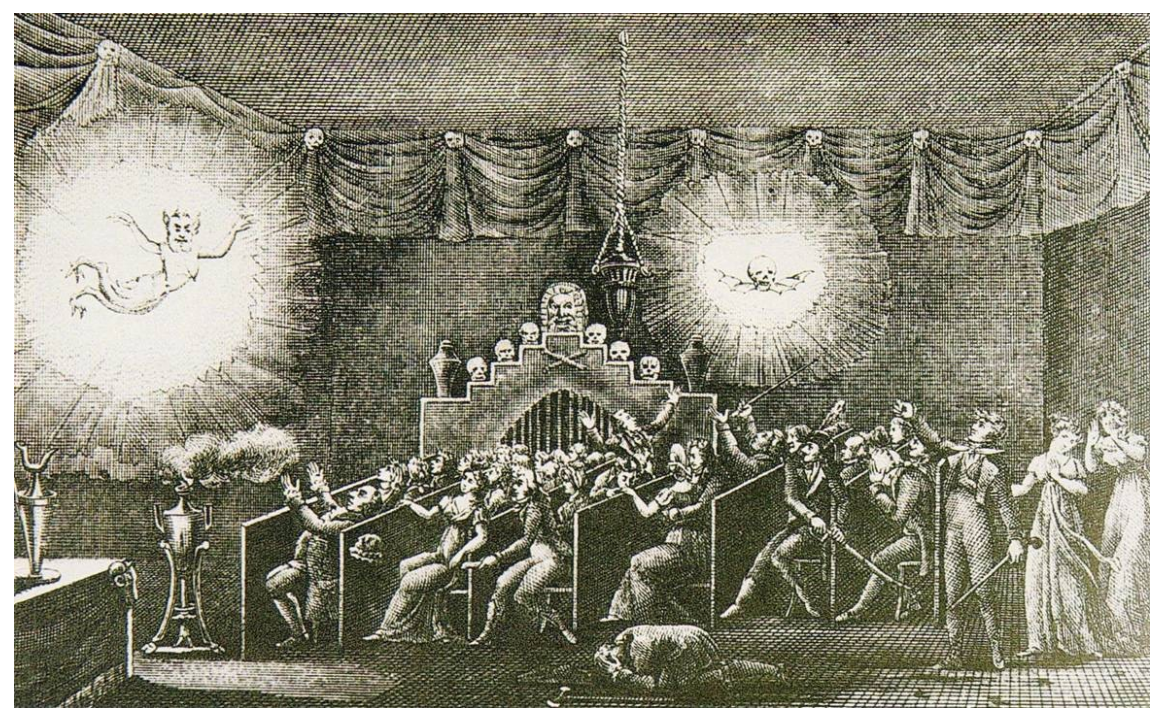

Fig.58 Fantasmagoria de Etienne-Gaspard Robertson, em Mémories récreatives scientifiques et enecdotiques, frontoscópicio, Paris, 1831

Assim, durante a exibição das fantasmagorias, os exibidores sublinhavam o aspecto das imagens de 'parecer, mas não ser real' (questões pertinentes, ainda hoje, no teatro tecnológico, sobretudo no campo das projeções de imagem em cena), advertindo os espectadores de que o que era projetado era apenas uma imagem, mas que, mesmo assim, se acreditaria ser real.

Entretanto, depois disso, as luzes se apagavam, e o espetáculo ilusionista começava com aparições de personagens históricos já falecidos, causando um inquietante tipo de medo nos espectadores, ainda que essas sessões fossem efetivamente anunciadas como ilusões ópticas.

Ainda hoje vemos esse o mesmo uso da fantasmagoria, em artistas cênicos contemporâneos, como é o caso dos diretores canadenses Michael Lemieux e Victor Pilon $^{39}$, que avançaram no uso da mesma técnica e fazem dela a grande característica de seus trabalhos. Há também reflexos sobre o fantasmagórico: o trabalho mídiaarqueológico da artista brasileira Rosângela Rennó ${ }^{40}$, de 2004, Experiencing Cinema. Consiste na projeção intermitente de fotografias numa tela volátil, feita de fumaça não tóxica, a partir de óleo vegetal, e também The influencing machine, de Tony Oursler ${ }^{41}$,

\footnotetext{
${ }^{39}$ Lemiuex e Pilon, dupla canadense de diretores, cenógrafos e compositores que desenvolveram a técnica da fantasmagoria

${ }^{40}$ Rosangela Rennó, artista plástica mineira nascida em 1962, formada em arquitetura e artes plásticas

${ }^{41}$ Tony Oursler, artista plástico americano, nascido em Nova York em 1957; explora em seus trabalhos as relações do vídeo e do corpo subvertendo as 'telas de projeção' com objetos tridimensionais. Tem seus trabalho expostos em importantes museus do mundo
} 
uma psicopaisagem para o Soho Square, em Nova York, que faz uma reflexão sobre os shows históricos que invocam o "espírito" do lugar, como a fantasmagoria. Vale também examinar os trabalhos de Gary Hill ${ }^{42}$, Douglas Gordon ${ }^{43}$ ou Laurie Anderson ${ }^{44}$.

\subsection{A dança (multimídia) de Loïe Fuller}

No campo da dança, destaca-se a dançarina Loïe Fuller que fornece um interessante exemplo realizando extraordinários experimentos, a partir de 1889, com a então "nova tecnologia" da eletricidade. Fuller, uma contemporânea de Isadora Duncan, atuou usando um enorme diáfano e semitransparente robe de gaze final segurando nas mãos, longos bastões estendidos ao longo do comprimento de seus braços (Fig.57).

Enquanto ela dançava e girava em círculos, os robes esvoaçantes se tornaram uma espécie de tela sobre a qual foram projetados feixes de luz multidirecionais e multicoloridos, incluindo aqueles emanados de um painel de espelho que a iluminava por baixo.

Os complexos jogos de luz sobre as grandes dobras que se estendiam ao longe no espaço, além dos restritos limites de seu corpo, transformavam (ou, na linguagem de computador, 'morphed') a forma do corpo da dançarina e sua forma visual. A então "alta" tecnologia da luz elétrica combinada com a "baixa" tecnologia de extensões de bastões de madeira estavam escondidos para transformar o fluxo de energia do corpo humano em uma imagem de pura energia e luz, que magicamente fazia aparecer metáforas de nuvens, borboletas e fogo dançante. Como nas manifestações de dança de hoje que utilizam de recursos tecnológicos, Fuller diminuía a corporeidade do corpo a fim de transformar sua materialidade, ou torná-lo imaterial, e apresentá-lo como uma metamorfose (tecnológica).

\footnotetext{
${ }^{42}$ Gary Hill, artista americano, nascido em 1951, um dos grandes nomes da vídeo-instalação

${ }^{43}$ Douglas Gordon, artista escocês, nascido em 1966, explora as relações do vídeo e da instalação, com trabalhos expostos na Bienal de Veneza e em grandes museus e galerias da Europa

${ }^{44}$ Laurie Anderson, artista experimental americana nascida em 1947, conhecida por suas performances multimídias e por álbuns musicais e clips realizados. Sua carreira é composta por numerosas performances, exposições, discos e colaborações diversas com artistas como William Burroughs, Peter Gabriel, Philip Glass, Ryuichi Sakamoto, entre outros.
} 


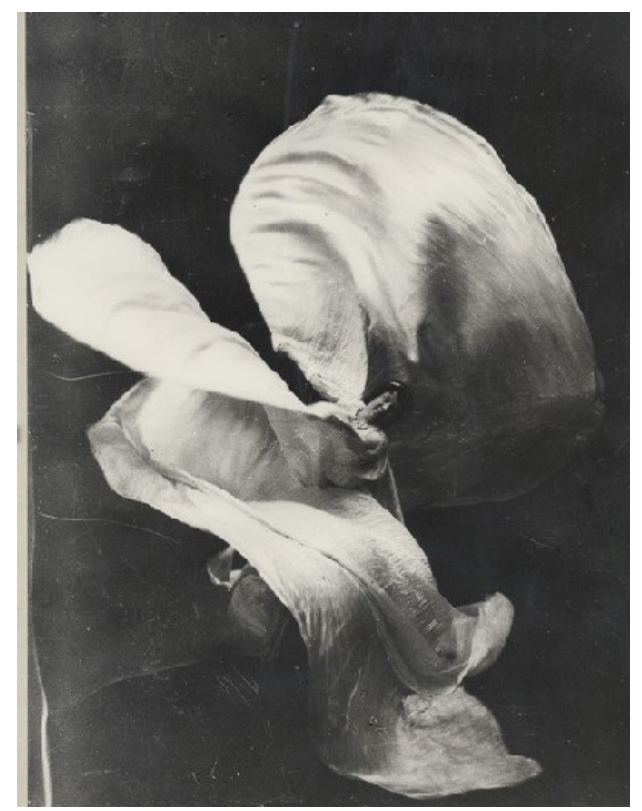

Fig.59 Conhecida como "Deusa da Luz", Loïe Fuller não tinha formação em dança, mas os movimentos feitos por ela foram inovadores e fez com que se tornasse um marco na história do cinema, figurino e da dança

Foi a primeira coreógrafa da dança moderna a usar novas tecnologias em seu trabalho, continuou seus experimentos até 1923, morreu em 1928, incorporando projeções de filmes e efeitos de sombra como um meio de transformar a forma de seu corpo em performance viva e criou uma peça onde ela tentava fazer com que suas roupas brilhassem.

A obra de Fuller pode ser vista como a pioneira em trabalhar a formação de mensagens com os efeitos de luz especiais fragmentadas no corpo dançante, fazendo-o parecer que muda de uma forma para outra, lançando algumas secções de seu corpo na sombra e iluminando outras.

Segundo críticos e pesquisadores, as influências das tecnologias vão sendo engendradas e trabalhadas por todos os movimentos de vanguarda, desde Schlemmer e os experimentos da Bauhaus de Gropius, até o futurismo, o construtivismo, o expressionismo, o dadaísmo e o surrealismo.

\subsection{O "Teatro do Futuro" de Robert Edmond Jones}

Ainda que pouco teatro multimídia tenha sido realizado nos anos 40 e início dos anos 50, por todo esse período Robert Edmond Jones foi um cenógrafo americano que desenvolveu projetos para a iluminação cênica e indumentária. A ele é creditado como a 
incorporação do novo stagecraft para o teatro americano (Fig.58). Seus projetos revolucionam elementos cênicos, antes utilizados separadamente e de forma indiferente, e seu estilo visual permeia do simplificado realismo ao arrojado.

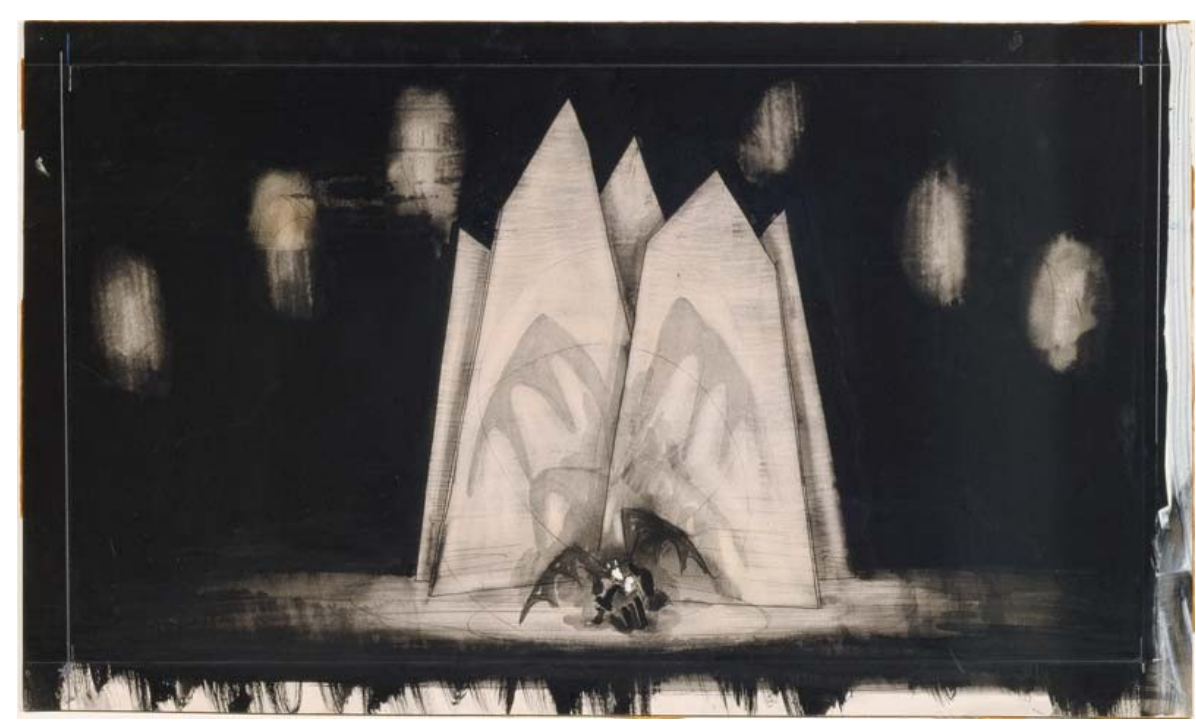

Fig.60 Desenho de cena de Robert Edmond Jones para a Ópera The Hand of Fate, 1930

Percorreu os Estados Unidos, entre 1941 e 1952, para pregar seus ensinamentos, o que Frederick C. Packard Jr. ${ }^{45}$ descreve como um "missionário ardoroso", fazendo palestras com títulos como "O Teatro do Futuro". A visão de Jones, inicialmente discutida em 1929 numa contribuição para a Encyclopedia Britânica, intitulada "Theory of Modern Production", foi a fusão de teatro e cinema. Segundo ele:

\begin{abstract}
No uso simultâneo do ator vivo e do quadro falante (...) o filme oferece uma resolução para o problema dos ali se encontra uma arte teatral inteiramente nova, uma arte cujas possibilidades são tão infinitas como aquelas do próprio discurso dramaturgos de teatro de expressar efetivamente a realidade íntima e subconsciente de seu caráter, uma vez que o filme oferecia uma 'uma expressão direta do pensamento antes que ele fosse articulado (...) o filme de cinema é o pensamento tornado visível. (DIXON, 2007, p.56)
\end{abstract}

Em seu "teatro do futuro", o ator ao vivo poderia assim representar o EU exterior do seu caráter e na tela imaginária o mundo mais íntimo da imaginação, do subconsciente e do sonho: os dois mundos que juntos formam o mundo em que vivemos. A síntese do filme e do teatro foi um tema amplamente discutido por Jones no livro The Dramatic Imagination, 1941, na época, o principal livro-texto para os estudantes de teatro americanos, e mais tarde retrabalhados e destilados como grandes

\footnotetext{
${ }^{45}$ Packard Jr, professor na área de artes da Harvard University durante 45 anos
} 
discursos, durante anos de palestra em viagens pelo país.

As palestras, finalmente transcritas por Delbert Unruh ${ }^{46}$ e publicadas em 1992 com o título Towards a New Theatre, essencialmente elabora as ideias expressas no artigo da Encyclopedia Britânica de 1929. Em seus artigos explica, em termos quase freudianos, como imagens de filmes podem ser usadas para revelar os pensamentos e sentimentos mais íntimos de um personagem:

No palco: sua vida exterior; na tela: sua vida mais intima. O palco usado objetivamente, a tela usada subjetivamente, em um tipo de contraponto dramático. O motivo é revelado na ação, mas a ação e motivo simultaneamente revelados para nós. A expressão simultânea dos dois lados de nossa natureza é um exato paralelo para nosso processo de vida. Estamos vivendo em dois mundos ao mesmo tempo, um mundo exterior da atualidade e um interno mundo da visão. (DIXON, 2007, p. 81)

Jones não fornece amostras de cenários e os poucos exemplos dos tipos de imagens de telas subconscientes que ele vislumbra são moderadamente desgastadas, sem melhores exemplos, defendendo intuitivamente que a plateia faria a diferenciação entre as realidades propostas. Ele deixa reflexões interessantes:

o visitante é levado ao cinema, onde ele descreve o filme como um meio de puro pensamento: Este drama da tela que estamos assistindo não é um drama de verdade - é o sonho de um drama, o pensamento de um drama (...) Durante as últimas horas nós estivemos sonhando (...) Esta é uma mídia de sonho. (...) O filme que ele testemunha, que ele assiste é um substituto, uma imitação, um teatro do "pobre homem," quando deveria ser pura seqüência de imagens, puro manancial de pensamentos, puro sonho. 0 visitante então corre para fora do cinema e entra num teatro por alguns poucos minutos para comparar os dois. Ele descreve as contrastantes ontologias do espectador nos dois espaços: a compartilhada, comunal experiência do teatro, sua platéia cada vez mais acordada; os espectadores sonâmbulos do cinema "uma aglomeração, não uma entidade, cada pessoa solitária e sonhando separada-mente, ainda que sonhem o mesmo sonho". (DIXON, 2007, p. 81)

Finalmente, Jones e o visitante comparecem a um teatro onde um comediante de vaudeville canta uma canção enquanto atrás dele uma imagem do filme dele é projetada. Este fragmento de uma comedia musical é "o germe de um novo teatro" de ilimitáveis possibilidades. "Um homem canta para nós e seu eu interior canta com ele. Tal coisa nunca tinha acontecido antes na história do teatro (...) é ínfimo, é tentativa, mas está vivo. E é o pivô".

Em seu relacionamento com o ator em cena, a imagem do filme se torna

\footnotetext{
${ }^{46}$ Unruh é cenógrafo e professor de teatro e cinema na Universidade do Kansas
} 
"pensamento visível" e "visível emoção", criando uma nova e expressiva forma de conjugar o subjetivo, a qualidade do sonho do filme com a força da atualidade em que "a parte desincorporada" do atuante encontra a parte incorporada.

Os esquecidos discursos de Jones constituem a primeira das principais teorias do teatro multimídia e permanecem importantes para nossa compreensão de muitos trabalhos de performance digital. Ele define os princípios fundamentais e divisões entre o teatro e a mídia de cinema, incluindo seus modos contrastantes de audiência que afetam as experiências sensorial e psicológica das plateias.

Essas ideias estão sendo agora infindavelmente re-ensaiadas e recicladas pelos numerosos escritores presos a definições ontológicas em discussões atuais de "vividez", normalmente sem qualquer referência a ele. Jones é um dos primeiros teóricos a analisar e definir precisamente porque nossas energias mentais e metabolismos físicos parecem se alterar quando assistimos uma performance ao vivo ou um trabalho gravado.

A compreensão de Jones dos corpos filmados e projetados como "desincorporados (...) parte do próprio eu enviado pela vontade", também prevê teorias paralelas do corpo virtual dentro da cibercultura, que eram consideradas ideias radicais no início dos anos 90 e que cinquenta anos antes Jones já havia teorizado.

O argumento de Jones difere em campos da teoria virtual no seu chamado para reunir os corpos, virtual e físico, desde que o corpo virtual em si próprio, como imagem no cinema, aparição, memória ou lembrança. Jones enfatiza que a cena deve ser levada para a conjunção com um corpo vivo para acionar um teatro total, baseado em um paradigma quase espiritual de tornar inteiro um corpo dividido.

\footnotetext{
Por outro lado, uma possível leitura da ciber-teoria do "corpo virtual", invoca a "divisão cartesiana entre a mente e o corpo: com efeito, a mente e o corpo permutam papéis com a mente projetada para fora, para se tornar um corpo virtual operando no ciberespaço. (LEMOS, 2002, p. 19)
}

O teatro de Jones diz respeito a sua unificação simbólica no espaço e tempo real e virtual, mente (filme) e corpo (palco). A metafórica trama de "Curious and Profitable" em que Jones conversa com seu próprio dublê, encaixa a metáfora central para o teatro que ele vislumbra "um teatro dublado, como estamos vendo hoje, onde atores e dançarinos atuam com seus dublês e com o seu "outro - eu" (alter-ego) 
projetado".

\title{
3.50 corpo vídeo
}

O vídeo surge em seus primórdios como meio de captar e reproduzir a realidade urgente, sem necessitar grandes maquinarias para a sua produção. Aparece como forma de extensão dos olhos, de ver o que acontece ao vivo ou num passado não tão distante e até mesmo o que não se pode ver com os próprios olhos, sem a necessidade de estar fisicamente no local do evento.

Por permitir essa intimidade no momento de sua produção, foi largamente utilizado por artistas para expor seus momentos cotidianos, confessionais e reservados. Usado como registro de algo passado, o vídeo substituía a ação em si tornando-se uma prova do acontecido uma marca no tempo, um instante congelado que poderia ser "reproduzido" ao infinito e superar a questão temporal. Nam June Paik, Bruce Nauman, Andy Warhol, Vito Acconci foram os primeiros a usar, nos anos 60 e 70, o vídeo como registro de performances suas ou de outros: ou de transformar algo comum num evento, recortar e direcionar o olhar do espectador para algum evento do cotidiano.

\begin{abstract}
Nos anos 70 fazer vídeo, era descobrir o vídeo (Nam June Paik, Bill Viola) mas a videoarte só toma real impulso nos anos 80 (Viola, Garry Hill, Zbigniew Rybcynski). O vídeo experimental - a ideia do videoautor (Arthur Omar, Édder Santos, Artur Matuk, Marcelo Tass, Marco do Valle, Walter Silveira, Paulo laurentiz, Sandra Kogut). Passa a ser reconhecido como domínio estético autônomo, domínio “impuro" em quer imagens de diferentes origens se combinam, numa fusão de campos e mídias. (BENTES, 2008)
\end{abstract}

Ao mesmo tempo de sua popularização começaram as experimentações com a linguagem videográfica, e suas possibilidades de colagem, recursividade, looping em trabalhos cênicos, como no grupo americano Wooster Group, e em experiências em dança. Ao mesmo tempo que o vídeo era o maior ícone da cultura de massa, torna-se também uma arma contra a cultura de massa, já que a apropriação e manipulação de imagens e ícones televisivos foi um dos pilares da videoarte.

Seguiram-se as manipulações da imagem, a fusão com a animação e a introdução do computador foi decisiva para gerar novos conteúdos. Linguagem foram 
desenvolvidas, o videoclipe assume sua forma fragmentada, a videoarte toma impulso nos anos 80 com experimentações inovadoras de artistas como Zbigniew Rybczynski ${ }^{47}$ com a colagem de vídeos em Tango (1981) e a manipulação de imagem distorcida em Fourth Dimension (1988). Assim inicia experimentações entre o vídeo e o corpo, seja em pequenas performances ou em vídeo instalações que também flertavam com o uso do vídeo sobre ou a partir do corpo.

\subsection{As imagens tecnológicas e o corpo}

A seguir mostro algumas importantes experiências no campo das imagens tecnológicas em diálogos tão ricos como poético com o corpo, em todos exemplos citados a seguir perceberemos um lugar de importância entre o corpo e o corpo que as vezes é representado pelas imagens projetadas ou transformado em soma com elementos de softwares de interação ou até mesmo a simples duplicação e transmissão desse corpo em lugares diferentes e em tempo real causando um efeito de presença que a poética reside justo na ausência do corpo real.

Neste seara indico o trabalho do artista e performer inglês Paul Sermon, pesquisador desde 2000 em ambientes temáticos e imersivos no Research Centre for Art \& Design, da University of Salford. É um dos pioneiros da arte telemática, conhecido por um dos trabalhos mais emblemáticos dos novos meios: Telematic Dreaming (Fig.59).

Neste trabalho, duas camas e duas pessoas em dois locais distintos e distantes; no topo de cada cama encontra-se uma câmera que filma o corpo de um, para que no outro local um projetor emita esta imagem na cama do outro. A primeira exibição do trabalho ocorreu em 1992 e podemos considerar como um dos mais importantes antecedentes da Realidade Virtual com implicações telemáticas.

\footnotetext{
${ }^{47}$ Rybczynski (1949) cineasta polonês, professor de fotografia digital e fotografia de cinema com reconhecimento internacional
} 


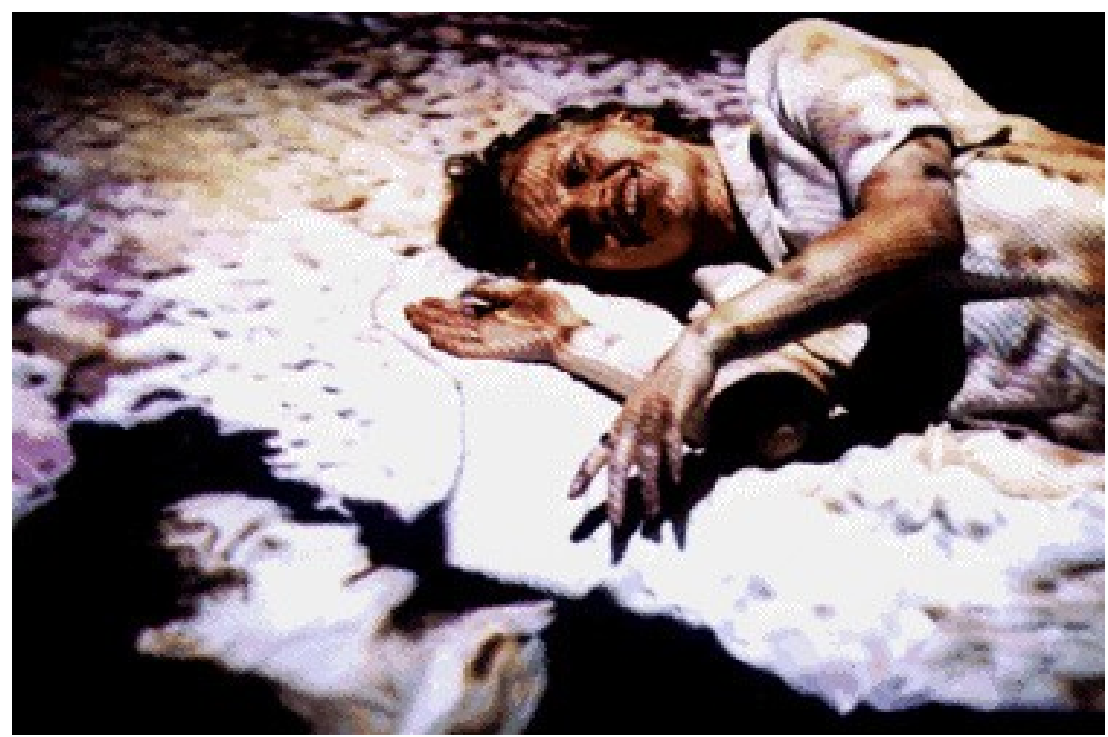

Fig.61 Cena da performance Telematic Dreaming, de Paul Sermon, projeto iniciado em 1992

As poéticas de leitura desse trabalho não só focam ao corpo, mas também ao efeito de presença de um corpo em uma cama, criando assim uma "interação" entre um casal que nunca se estabelece por completo, porque o casal é metade real e metade transmitido por projeções de vídeo em tempo real, essa distância real geográfica entre os corpos na cama, da obra de Sermon, potencializa de forma pertinente os tempos em que os relacionamentos são cada vez mais refletidos e questionados.

\subsection{Os corpos fantásticos de Tony Oursler}

Um dos primeiros artistas a trabalhar com formas físicas, basicamente rostos humanos em vídeo instalações foi o artista Tony Oursler, que já teve seus trabalhos expostos em importantes museus, tais como o Museu de Arte Moderna de Nova York, o Museu Whitney de Arte Americana e a Tate Gallery em Londres. É um artista cujo nome é destacado pela crítica mundial como uma das figuras mais importantes da recente história da videoarte.

Muitos o consideram um dos criadores da vídeo-escultura. Seu caráter inovador permitiu-lhe, ao longo dos anos, experimentar o vídeo como meio de expressão por meio das imagens em movimento buscando representar a cultura contemporânea. Ele não apenas queria expressar-se através das imagens de vídeo em sentido estrito, como 
também, de um modo mais original, utilizava e conjugava o vídeo com a escultura, o design, a instalação e a performance.

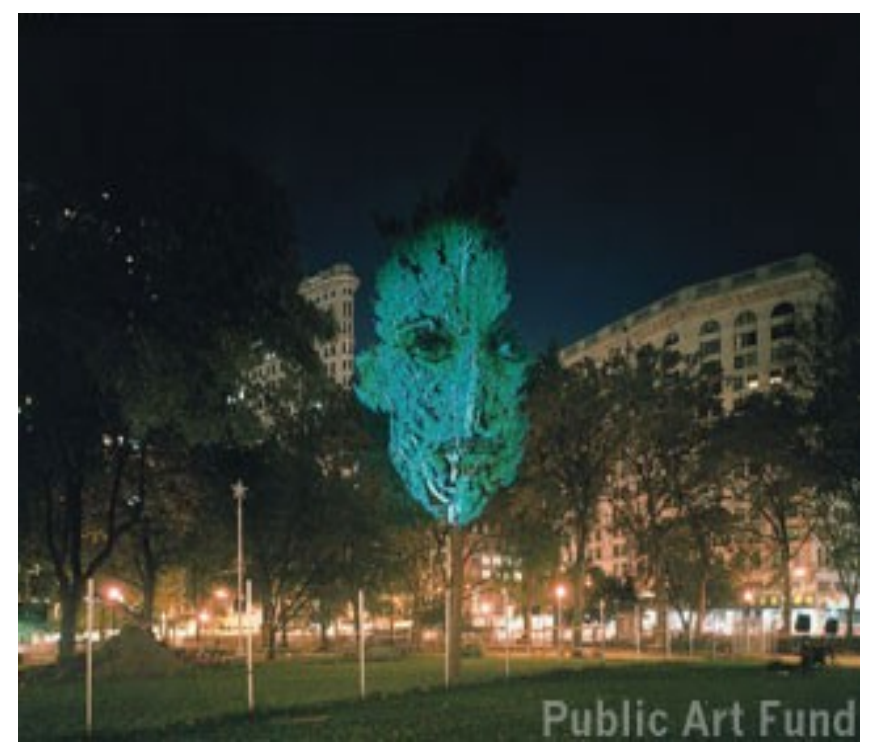

Fig.62 Cena da instalação The Influence Machine, realizada no Madison Square Park, em Nova York, 2000

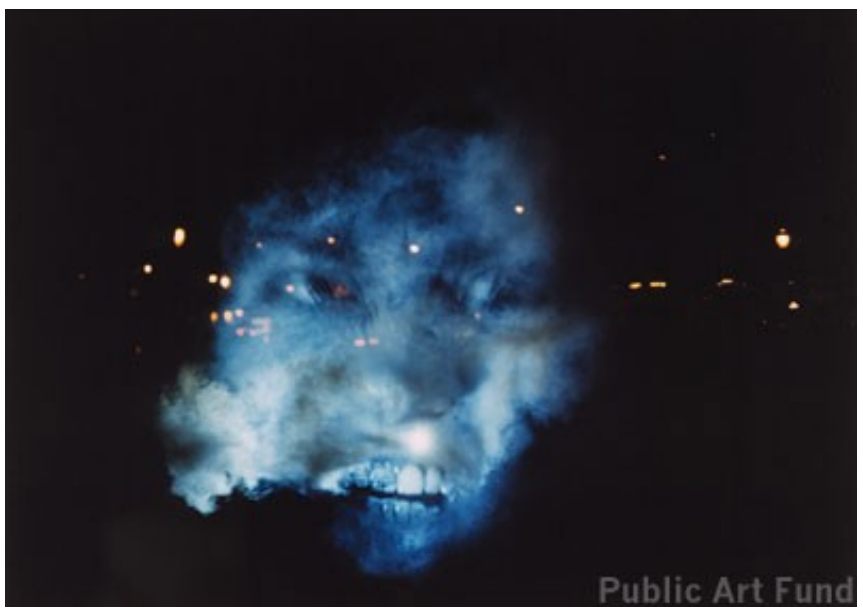

Fig.63 Cena da instalação The Influence Machine, realizada no Madison Square Park, em Nova York, 2000

Tony Oursler desenvolveu desde os anos 1980 um original processo de animação que o destaca entre os pioneiros da videoarte e das técnicas multimídia associadas à instalação, em que nunca projeta a imagem sobre uma tela plana. As obras de Oursler quase sempre incluem a animação de objetos com o uso de projetores, frequentemente fazendo uso de bonecos, que se tornaram a marca de seu trabalho. 


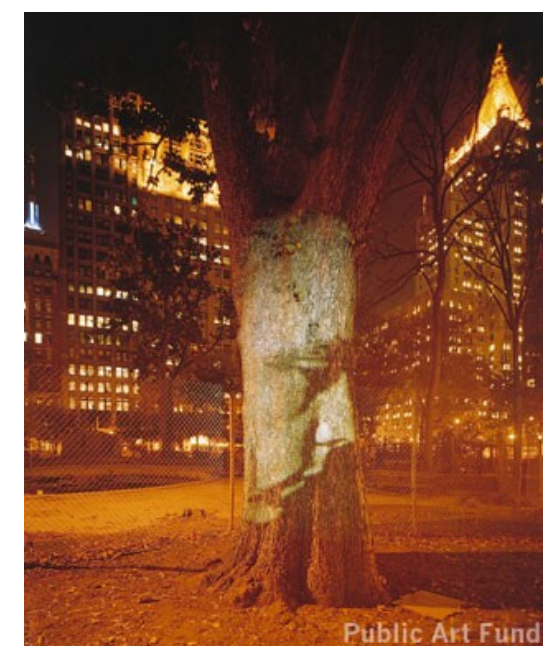

Fig.64 Cena da instalação The Influence Machine, realizada no Madison Square Park, em Nova York, 2000

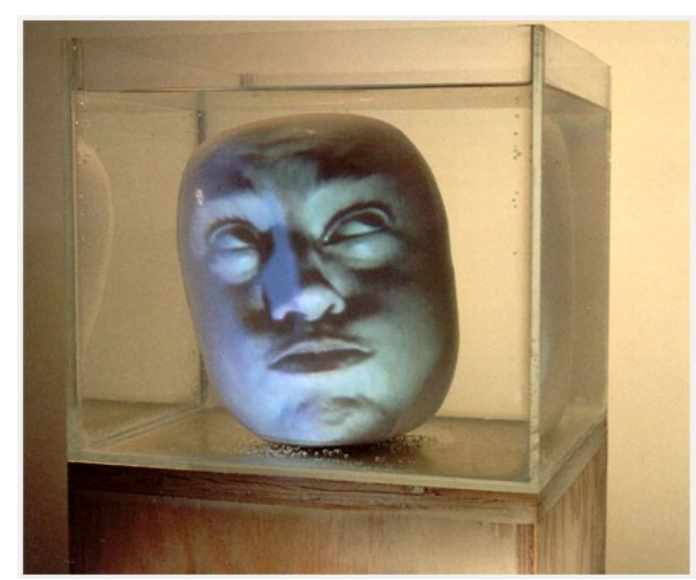

Fig.65 Cena da instalação Subemerged, de 2008

Oursler desenvolve um processo original de trabalho em animação que o destaca como um dos pioneiros da videoarte e das técnicas multimídia associadas às instalações. Em suas instalações, o espectador não observa imagens em uma superfície plana retangular. Ao contrário, o visitante vê flores animadas, olhos gigantes que piscam, bonecos que dialogam entre si, projeções de rostos falantes em nuvens de fumaça artificial, ou ate mesmo rostos de atuantes falando sendo projetados em copas de árvores, o que cria um atmosfera fantástica e delirante que nos devolve de forma crítica toda a imensa quantidade de imagens que consumimos diariamente (Fig. 62, 63, 64 e $65)$.

A temática de seus trabalhos é a falta de comunicação e o isolamento do sujeito na sociedade contemporânea, além de sua atração e obsessão pela esquizofrênica reprodução de imagens da cultura virtual norte-americana e global. Possibilitando toda 
uma nova forma de ver não somente o suporte das projeções do corpo, como também a recriação do corpo em suportes inusitados.

\subsection{As múltiplas faces de Denis Marleau}

Nascido em Valleyfield, em 1954, Tony Ourler influenciou diretamente o trabalho do diretor francês Denis Marleau. Alguns anos após os estudos no Conservatório de Arte Dramática de Montréal (Quebec), funda em 1982 o Théâtre UBU, no qual ainda hoje é o encenador principal. Já montou mais de trinta espetáculos, produzidos mais na Europa do que no Canadá.

Tendo como principal fio condutor do seu trabalho o texto teatral, já adaptou para o teatro textos de Schwitters, Tabucchi, Pessoa e Bernhard. Começou a sua atividade de encenador com peças de Tzaran, Picabia, Picasso, Stein e Appolinaire. Apesar de algumas incursões pelo teatro romântico alemão e pela dramaturgia quebequiana contemporânea, Denis Marleau nunca deixou de revisitar a vanguarda europeia, e mesmo a proto-vanguarda em Ubu Cycle (1989) e Les Ubs (1991), a partir de A. Jarry.

O trabalho de Marleau é particularmente visível no tratamento do corpo do ator que é submetido a dois processos diferentes, a mecanização e a desmaterialização, com o objetivo de combater a um certo realismo que privilegia a construção psicológica das personagens.

Ele também usa a projeção de rostos em cena sobre objetos, máscaras e, diferentemente de Ousrler, o diretor francês vai em busca de um espetáculo mais teatral. Foi assim com a adaptação de 'Os cegos', de Maurice Maeterlink ${ }^{48}$, precursor do que chamamos hoje de teatro pós-dramático; a montagem do canadense Denis está completamente condizente com as ideias do dramaturgo.

Marleau montou 'Os Cegos' (Fig.64 e 65) com uma animação de fotografias de pessoas que não interpretaram os personagens. A encenação é completamente tecnológica a ponto de que no final acende-se um pouco as luzes e o público pode ver o

\footnotetext{
${ }^{48}$ Maurice Maeterlink (1864-1862), dramaturgo, poeta e ensaísta; principal expoente do teatro simbolista
} 
aparato tecnológico utilizado. Rostos de atores / personagens projetados em máscaras feitas em gesso presas no palco escuro, as interpretações e dão somente pela presença das projeções, que se 'encaixam' perfeitamente ao rosto falso dos mesmos atores que antes foram gravados.

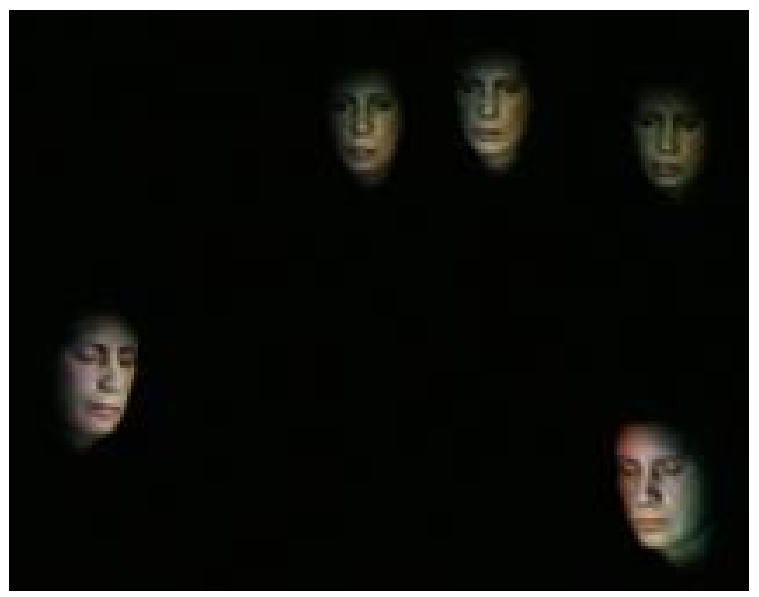

Fig. 66 Cena de 'Os cegos', com direção de Denis Marleau, em 2009

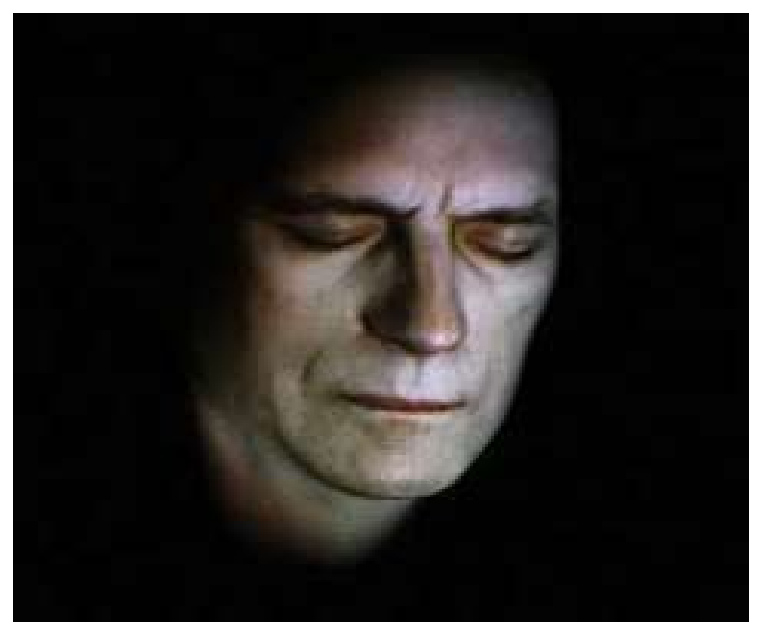

Fig. 67 Cena de 'Os cegos', com direção de Denis Marleau, em 2009

A encenação de Marleau nos remete muito a atmosfera incomunicável do dramaturgo ao contar a história de doze cegos que estão apavorados numa floresta esperando seu guia. A conversa, a ambientação sonora e a animação dos rostos nos remete ao que só consigo me referir como um sentimento de 'noite shakesperiana', em que tentamos penetrar o ambiente que nos é apresentado mas tudo está borrado, então o melhor a fazer é assumir a confusão e a falta de clareza.

A partir de projeções, a montagem da companhia Ubu Theatre, de Montreal, reproduz no palco os rostos dos atores, elimina sua presença física, e coloca em pauta os próprios limites entre o que é e o que não é teatro. Sentado em cima do palco, na 
penumbra, o público deve acompanhar de perto a agonia de um grupo de 12 cegos. Perdidos em uma floresta, eles não sabem que seu guia está morto, caído no chão, e acreditam que ele ainda voltará para buscá-los.

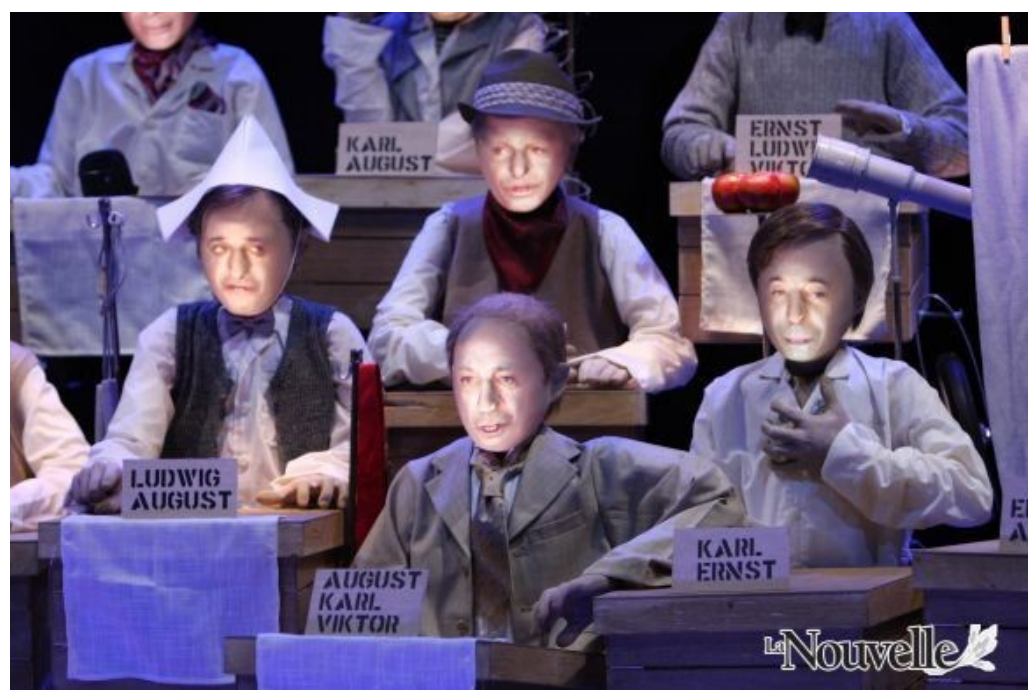

Fig. 68 Cena de 'Une fête pour Boris', direção de Denis Marleau, em 2010

No último trabalho de Dennis Marleau ele radicaliza os limites técnicos das imagens tecnológicas adquiridos em 'Os cegos' e cria o espetáculo 'Une fête pour Boris'(Fig.66), em que as projeções de rostos são retomadas, só que em bonecos móveis em que o mesmo ator maquiado e caracterizado de vários personagens interpreta 13 personagens, e seus rostos são novamente projetados em sincronia com o rosto feito em borracha látex.

Se trata de uma multiplicação do corpo (aqui, a face) em múltiplos bonecos, com múltiplas falas e nuances, aprofundando as possibilidades descobertas anteriormente e assim dando um salto não só técnico como estético. Mostrando novamente que o corpo via a projeção de imagens tecnológicas pode ser multiplicado, e desdobrado sobre suportes múltiplos.

\subsection{O hibridismo do Studio Azzuro}

Um dos maiores grupos de vídeo-arte internacional - o italiano Studio Azzuro fundado em 1982 pelos sócios Fábio Cirifino, Paolo Rosa, Leonardo Sangiorgi e Stefano Roveda o grupo trabalha no limite entre vídeo instalação e performance na possibilidade 
de encontrar poética e expressividade entre as tecnologias e as questões de sua época, através de vídeo ambientes, sensíveis e interativos e performance teatrais.

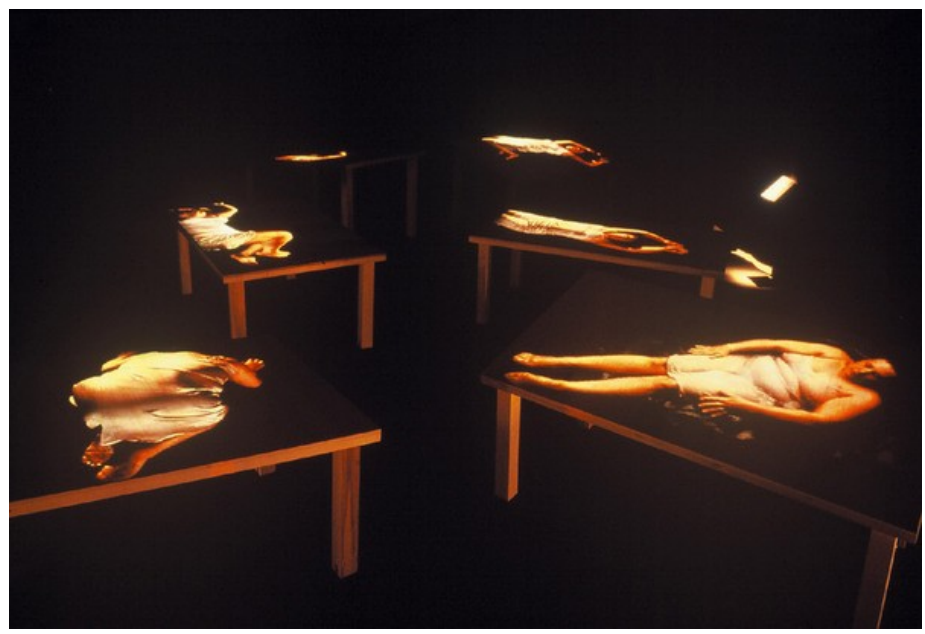

Fig.69 Cena do espetáculo do Studio Azzuro 'Partecipare La belleza', de 2009

Através da narração virtual, multimídia e interativa, o público vive uma experiência emocional podendo se colocar diretamente em contato com o universo do "Faber" um de seus trabalhos. A narrativa e as representações visual, textual e musical são cheias de lembranças e emoções e o público pode escolher qual imagem do compositor genovês partir para o desenvolvimento, em conexão com suas próprias vidas, através de quatro ambientes interativos que representam a poética, a música, os personagens e a vida.

Em seus trabalhos a linguagem do vídeo é levada a últimas potencias e a capacidade de projetar o corpo humano em mesas, objetos, telas circunferenciais e outros suportes, dão a imagem tecnológica do corpo sempre novos sentidos e possibilidade (Fig. 64).

\subsection{Marcel-li Antunez Roca e a imagem como interface para o corpo}

Um dos artistas que trabalham de forma mais inteligente com as questões de interatividade entre corpo e imagem tecnológica é o espanhol Marcel-li Antunez Roca, um dos membros fundadores do coletivo catalão La Fura dels Baus, grupo revolucionário na utilização do espaço cênico, mundialmente reconhecido, que criou uma estética muito particular, participando de diversas performances com o grupo até o ano de 1989. 
O artista é conhecido por suas instalações mecatrônicas e suas performances robóticas. Seus trabalhos mais recentes lidam com temas como o afeto, a identidade, a escatologia e a morte - na inserção entre o biológico e o artificial. Um dos seus trabalhos mais conhecidos é Epizoo, apresentado em diversos países. Com a intenção de produzir uma visão mais distópica da realidade virtual, o artista Marcel-li Antunez Roca, criou uma performance interativa a um só tempo delirante e assustadora.

'Epizoo' (Fig.67) foi primeiramente apresentada no México em 1994 e desde então foi vista em mais de 55 cidades; a obra foi vista no Rio de janeiro no Festival de Artes Cênicas do Rio, em outubro de 1997. O performer usa uma espécie de exoesqueleto metálico, uma pequena câmara presa numa luva, alto-falantes, e uma ampla tela de projeção elevada acima da pequena área de ação designada ao performer. Um computador também fazia parte do conjunto, mas se encontrava fora do círculo formado pela plateia.

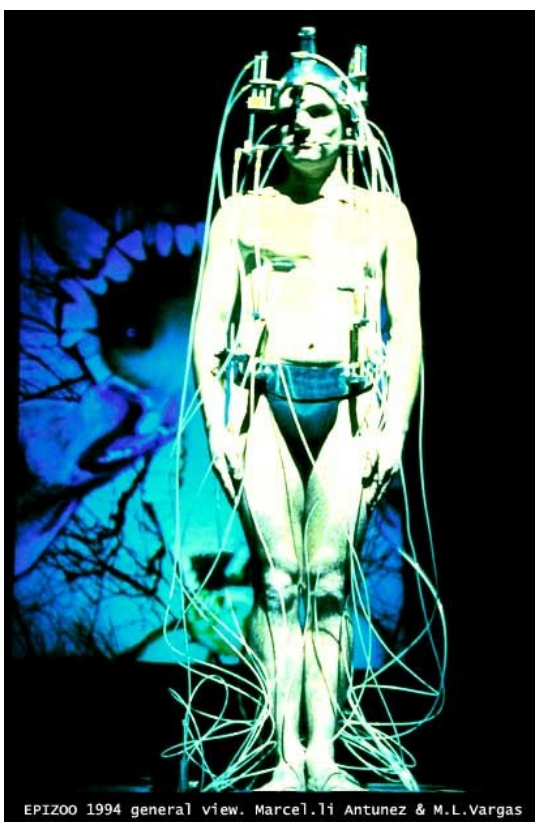

Fig.72 Cena da performance 'Epizoo', de Marcel-li Antunez Roca, de 1999

Marcel-li desenvolveu um exoesqueleto, que plugado ao seu corpo, reage aos movimentos dos membros e expressividades da face criando no palco a imagem de um cyborg, mistura de homem e máquina. No aparato havia componentes de metal que foram postos em várias partes do corpo do artista, como por exemplo no peito, nos ouvidos, na boca, no nariz e nas nádegas. À medida que uma pessoa ao computador ativava o corpo do artista, movendo suas partes numa coreografia peculiar, também 
ficou claro que a mobilidade limitada do artista era igualmente significativa, evocando os perigos das tecnologias de controle.

Seu corpo estava sob controle alheio. As imagens digitais vistas na tela mesclam de fotografias e animações que em geral incluíam a própria imagem do artista e funcionavam perfeitamente como uma interface para o seu corpo. Ao mesmo tempo bem-humoradas em seu tratamento e terríveis no conteúdo, tais imagens retratavam cenas de tortura e de violência, transformando as partes do corpo em elementos combinatórios e disponíveis.

O artista se virava regularmente para revelar todos os ângulos de vista possíveis. Com a luva-câmara (câmara presa à luva), ele acrescentou pontos de visão adicionais, levantando e balançando a mão. A edição em tempo real possibilitou ao público ver a combinação entre a interface digital e o vídeo ao vivo.

Marcel-li a partir desse trabalho desenvolveu e sofisticou esse princípio com outras obras como Protomembrana (Fig.68), Hipermembrana e Metamembrana; todas utilizando um diálogo inteligente e interativo entre as possibilidades de atuação junto aos movimentos de seu corpo preso ao exoesqueleto que controla todo o aparato de projeção de imagens num telão atrás do performer.

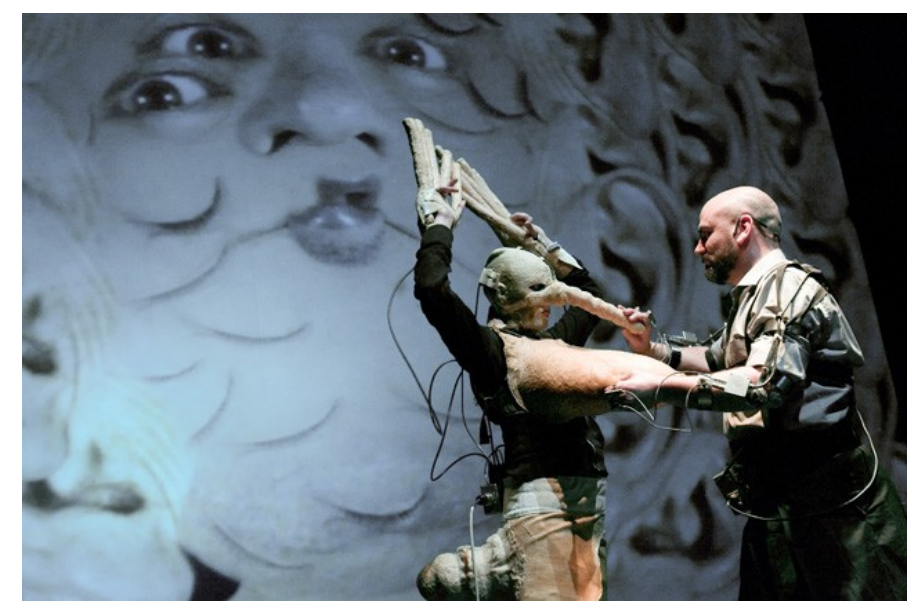

Fig.73 Cena da performance Protomembrana, de Marcel-li Antunez Roca, de 2006

Esses movimentos físicos do corpo de Marcel-li podem ativar, avançar e pausar todos os recursos do vídeo, criando assim uma edição videográfica que dialoga com sua proposta corporal ao mesmo tempo que altera profundamente nossa percepção, às vezes alternando como efeito pedagógico ilustrativo de suas teorias a cerca da 
tecnologia e o corpo, às vezes criando uma estranheza entre ação e imagem tecnológica ao fundo.

Suas performances provocam uma reflexão sobre temas e questões que configuram nossa vida cotidiana modificada por estímulos digitais que podem alterar o modo de viver. Em tom messiânico e muitas vezes engraçado, esse "bufão digital" faz uma dramaturgia de hiperlinks que se soltam e se sobrepõem como os vídeos, em geral desenhos feitos e animados por ele próprio.

Em todas as suas obras o corpo é sempre seu corpo e tem sido cenário e espaço físico onde se dá, além da interação corpo e tecnologia, suas poéticas frente aos mitos clássicos que se apropria para (re) desenhar uma nova mitologia de seres híbridos, cyborgs, que misturam fases da vida do próprio artista, aumentando a carga performativa do trabalho, ora também muito teatral, não abrindo mão de recursos clichês do teatro de variedades.

O importante de citar Marcel-li Antunez Roca é que carrega toda a provocação e inteligência que o coletivo catalão La Fura dels Baus tinha no início de sua carreira, mas agora em ações solo, em que a linguagem furera ainda toma espaços com radicalismos e possibilidades de transcender o corpo em cena, cenário, espaço e problematizar teorias sobre o futuro dos corpos hibridizados.

As imagens tecnológicas projetadas e alteradas a todo tempo são elementos gráficos presentes em todo seu trabalho, e funciona claramente como além de uma prótese, o vídeo é uma extensão do corpo do performer já que responde a todos estímulos (sonoros e físicos) do performer.

Podendo configurar muitas vezes imagens gravadas ao vivo de pessoas do público na platéia, que se tornam 'personagem' da vasta fauna de criaturas desenhadas por Marcel-li que às vezes são trocadas pela face de pessoas do público, trazendo a plateia personagens bizarros, que configura mais que simples interação com a plateia, mas rascunhos de possibilidades desses novos corpos que o artista profetiza.

O corpo biocibernético é a nomeação encontrada para a discussão que traz à tona as formas diferenciadas pelas quais o corpo trabalha com as tecnologias e as transformações, que podem se suceder do encontro do homem, em simbiose com a máquina. O corpo biológico invade os territórios das tecnologias e as novas noções 
podem modificar o corpo em sua limitação humana, trazendo um ser híbrido que manipula dispositivo em prol de uma superação do orgânico.

O artista Marcel-lí Antúnez Roca desenvolve seus trabalhos na integração do corpo e tecnologia e considera que a discussão interessante acontece entre os avanços técnicos e científicos em integração à natureza humana limitada.

O espetáculo 'Afasia', baseado na epopéia Odisséia, de Homero, mas que não faz uso do texto, ficando entre a fronteira do visual e o cênico, investiga as possibilidades interativas hipermidiáticas dos novos suportes e linguagens multimídia, assim como as novas interfaces corporais. Em 1996, Marceli-li junto com artista e performer brasileiro Eduardo Kac, desenvolveram um 'Manifesto da Arte Robótica', um texto provocativo que aponta questões que ambos artistas buscam sobre as experiências entre corpo e tecnologia:

Al expandir la definición limitada de robot en campos como la ciencia, la ingeniería y la industria, los ART ROBOTS (los robots artísticos) abren una puerta a la crítica social, las preocupaciones personales y el libre juego de la imaginación y la fantasía. Los robots son objetos que funcionan en el tiempo y el espacio. Sus estructuras espacio-temporales abiertas y diversas permiten dar respuestas específicas a diferentes estímulos. Algunas de las formas que puede tomar el arte robótica incluyen agentes autónomos de espacio real, autómatas biomórficos, prótesis electrónicas integradas con organismos vivos y telerobots (incluyendo a los webots).

Los robots no son solamente objetos que el público puede percibir-como ocurre con todas las otras manifestaciones artísticas-, sino que son capaces de percibir al público por sí mismos, respondiendo de acuerdo con las posibilidades de sus sensores. Los robots manifiestan comportamientos. El comportamiento robótico puede ser mimético, sintético, o una combinación de ambos. Al simular aspectos físicos y temporales de nuestra existencia, los robots pueden inventar nuevos comportamientos.

Una de las principales preocupaciones del arte robótica es la propia naturaleza del comportamiento de un robot: ¿Es autónomo, semi-autónomo, sensible, interactivo, orgánico, adaptable, telepresencial o de algún otro tipo? El comportamiento de otros agentes con los cuales pueden interactuar los robots es también un factor clave del arte robótica. La interacción que se produce entre todos los elementos que forman parte de una pieza determinada (robots, humanos, etc) define las cualidades específicas de esa pieza.

Los robots no son esculturas, pinturas o video arte. LOS ART ROBOTS no deben confundirse con las estatuas o esculturas estáticas y antropomórficas de aspecto mecánico (ni siquiera con las que muestran imágenes de video en movimiento). Los programas que recuperan información y realizan otras funciones en Internet, aunque reciben el nombre engañoso de robots de Internet, o Netbots, no tienen nada que ver con el arte robótica. El arte robótica siempre conlleva un componente de espacio real.

Los robots son una nueva forma de arte, y son propensos a hibridizarse con diversas tecnologías. Esta cualidad les hace trascender la categoría de objeto para difuminarse en el entorno. 
El arte robótica puede darse en espacios físicos, en el espacio telemático, en entornos virtuales o en cualquier combinación de estos espacios que incluya una ubicación real.

Los robots son algo nuevo en el mundo del arte. El arte robótica tiene antecedentes en el trabajo de artistas como Tinguely y Paik, pero constituye una forma de arte única por derecho propio, diferente de la escultura, el vídeo, la performance $y$ otras prácticas artísticas comunes. Hay prototipos en máquinas secuenciales que repiten incesantemente sus estructuras temporales. Sólo los microprocesadores permiten un comportamiento más complejo y distinto cada vez, ya sea de forma específica o aleatoria. Los microprocesadores son tan importantes para el arte robótica como lo son los pinceles, la pintura y los lienzos para la pintura.

Los robots pertenecen a una nueva categoría de objetos y situaciones que rompe con la taxonomía tradicional del arte. Donde antes se hablaba de límites y fronteras ahora encontramos nuevos territorios. Estos nuevos terrenos artísticos están abiertos a nuevas posibilidades y se relacionan entre ellos de manera productiva. En estos nuevos terrenos heterodoxos nacen criaturas híbridas sin un modelo que las preceda. Combinada con los medios de telecomunicaciones, la robótica da lugar al arte telepresencial, en que el robot es el huésped de un sujeto alejado.

Como género, los robots no aspiran a convertirse en formas cerradas y fijas. Pueden perecer como concepto si se produce una nueva situación que los abarque y los sobrepase. Los robots existen en una confluencia de debate creativo y exploración conceptual que se manifiestan en los extensos dominios de la telemática y la cibernética. (ROCA ${ }^{49}, 1997$, p.56)

Se retomarmos a carreira, não só em performances, mas também como artista plástico, que concebeu várias instalações interativas, sempre com eixo as relações entre tecnologia e via, notamos que sua trajetória existe um nítido movimento de incomodo e subversão do normativo e do aceitado.

O discurso polêmico que vai desde sua arte de ações, sempre buscou transgredir os limites estabelecidos a partir de recursos como o corpo e ironia, absurdo, ridículo e alcança potências em seus experimentos que hoje configura em destaque em qualquer antologia sobre arte e tecnologia.

\begin{abstract}
Uma possível leitura desta obra é a crítica à extrema racionalização do homem, que acreditando tanto no poder das máquinas, fez uso exagerado das mesmas e hoje se encontra dominado pela tecnologia e o elemento humano da performace é menosprezado. A performance mostra uma manipulação que evoca dor, sofrimento, desumanidade, mostrando os perigos dos excessos da tecnologia. Essa ideia de tortura e de agente torturador passa a ser mais dramática quando o público aceita o convite para ser o manipulador via tecnologia do corpo alheio. A crítica é ao homem e a tecnologia-máquina é o meio utilizado para a crítica ser feita. (KAC, 2002, p.16)
\end{abstract}

Este relato de Eduardo Kac, em seu texto Novos Rumos da Arte Interativa, revela

\footnotetext{
${ }^{49}$ Originalmente publicado em inglês em Leonardo Eletronic Almanac-Volume 5
} 
um tom assustador e prossegue afirmando que, após um assistente do artista provocar várias alterações no corpo de Marcel-li através dos clicks, o público era convidado a assumir essa postura manipuladora do corpo alheio e de potencial agente causador de sofrimento a este corpo.

Menos cientista que Sterlac, porém mais teatral e mais imagético, o trabalho desse artista espanhol não só aponta para as novas possibilidades do corpo, e o uso das imagens projetadas e alteradas em tempo real aqui nos dá a medida certa de sua poética, criando assim obras hipermídias e ao mesmo tempo fundindo elementos da escatologia, sangue, carne e outros fluidos corpóreos, a máxima potência de maquinarias com aparato digital.

Antunez abre fissuras no campo do uso da interatividade no uso do vídeo em cena, já que esse vídeo é alterado pelo próprio movimento do corpo do performer, dispensando um técnico ou Vjs como na maioria dos casos. Finalmente toda essa simbiose entre mundo digital e mundo corporal aponta para uma visão utópica nada pessimista, em que os cruzamentos e proposições que o artista indica são de cunho colorido, positivo, engraçado e múltiplo, um valdeville digital onde corpo e máquina pretendem habitar um só espaço.

\subsection{A dança telemática}

Ao se falar em dança telemática é preciso compreender primeiro o que é telemática. De acordo com as pesquisas, de forma bastante resumida, telemática é o conjunto de tecnologias de transmissão de dados, possível graças à integração entre os recursos de comunicação (telefonia, satélite, cabo, fibras ópticas) e de informática (computadores, periféricos, softwares e sistema de redes). A telemática permite o armazenamento e transporte de informação em curto prazo de tempo entre usuários de qualquer lugar do mundo.

A informação transformada em bits e bytes, ou seja, em dados computáveis, pode ser enviada e reconfigurada num tempo quase real através da telemática. E isso inclui processamento de grande quantidade de dados, como texto, imagem e som. Nesse terreno não podemos deixar de considerar um espaço para citar os trabalhos do 
bailarino Merce Cunningham ${ }^{50}$, responsável pelos maiores saltos qualitativos da dança do século $X X$.

Mas assim como a arte do corpo redescobre a máquina um movimento no sentido oposto também acontece ao mesmo tempo. No universo dos artistas que operam com meios tecnológicos, Cunningham marca uma redescoberta das possibilidades das imagens tecnológicas em cena, e seu trabalho marco nesse sentido é a coreografia Biped (1999) por inaugurar uma nova etapa na interação entre dança e tecnologia: a da busca de preservar e manipular o movimento humano em outro suporte que não o corpo (Fig.69 e 70).

Cunnigham, debilitado fisicamente há alguns anos sofrendo de problemas como artrose, conseguiu com auxílio do computador desenvolver um novo corpo mediador entre ele, sua dança e seus bailarinos. Esse corpo digital passou a favorecer suas necessidades criativas, como um novo meio de comunicação entre criador e criação.

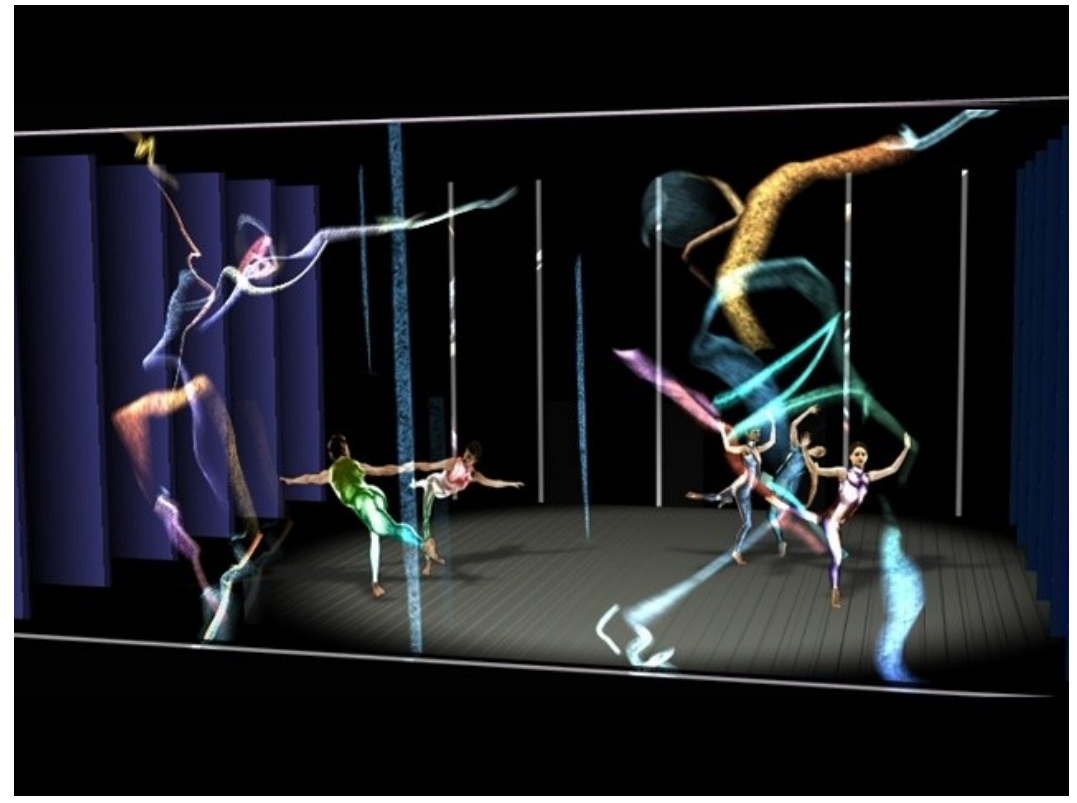

Fig. 74 Cena de 'Biped', de Merce Cunningham, de 1999

A ambientação de Biped é composta por projeções de imagens de corpos dançantes que Cunningham desenvolve nas suas pesquisas com simuladores de movimento humano, no computador. Linhas sinuosas, retas e pontos, que atravessam a

\footnotetext{
${ }^{50}$ Mercier Philip Cunningham, mais conhecido como Merce Cunningham (1919-2009), bailarino e coreógrafo norte americano, possuía como características marcantes de sua dança, o caráter experimental e o estilo vanguardista. Foi responsável por mudar os rumos da dança moderna. Criou mais de duzentas coreografias. Entre seus colaboradores figuram John Cage, Jasper Johns, Andy Warhol e Robert Rauschenberg.
} 
cena sem fluxo ou sentido regular, contribuem para a leitura dos corpos que estão em cena, reais e virtuais, a partir de suas geometrias. O espaço, estrela da peça, pulsa em todas as suas dimensões.

Com o desenvolvimento de Biped torna-se estranho o fato de que os bailarinos sejam prisioneiros do chão. A submissão à força da gravidade é o último traço que distingue os bailarinos de todos os outros corpos que dançam, aproximando-se e repelindo-se, no espaço. A música envolvente de Gavin Bryars ${ }^{51}$, os magníficos figurinos e a iluminação precisa são decisivos para sua beleza hipnotizante.

A dança enquanto expressão artística de nossa cultura atual é afetada e resignificada pelas tecnologias que nos perpassam. Valendo-se do uso tecnológico de diferentes maneiras, a dança também pode ser encontrada em telemática - entendida como uma performance realizada por bailarinos em diferentes localidades, via satélite ou internet.

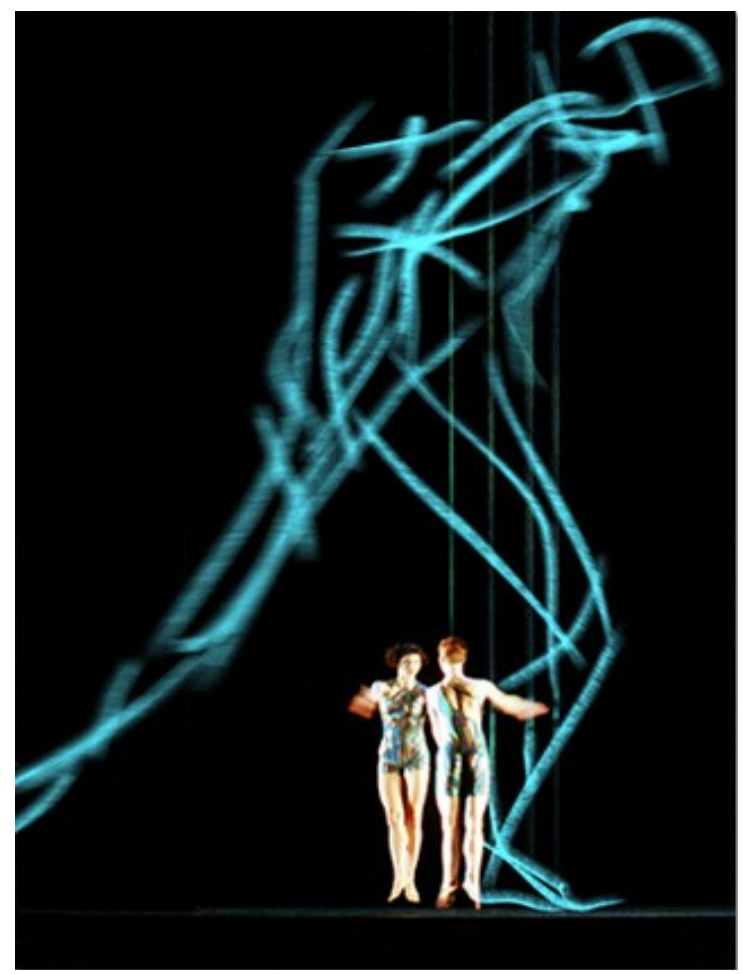

Fig.75 Cena de 'Biped', de Merce Cunningham, em 1999

Para que isso ocorra, o artista pode se valer de sistemas e softwares de animação, que encontram nas indústrias cinematográficas e de videogames suas principais investidoras. Um dos sistemas de digitalização do movimento humano é

\footnotetext{
${ }^{51}$ Músico americano nascido em Yorkshire (1943). Seu primeiro trabalho foi como baixista de jazz, que trabalhou com improvisação e diversos compositores relevantes
} 
chamado motion capture, como já citado no Capítulo 1, que câmeras e sensores óticos transferem a movimentação real para um equivalente virtual.

As câmeras servem para registrar os vários ângulos do movimento e idealmente trabalha-se com uma grande quantidade de câmeras (24 unidades permitem uma ótima captura). Os sensores são fixados nos corpos que serão digitalizados, sejam eles humanos ou não, e servem para transmitir as modulações do movimento. Os movimentos captados são enviados ao computador e transformados em dados que se reconfiguram como figuras virtuais ou avatares.

Uma série de etapas são necessárias para transformar esses dados num corpo tridimensional mas a leitura da captura do movimento pode ser vista de imediato. A movimentação convertida em informação digital reflete na tela do computador pontos luminosos que correspondem aos pontos onde foram fixados os sensores. Vale lembrar que o custo de um trabalho em telemática é muito alto, por vezes bem acima da realidade financeira dos projetos artísticos da área de dança e tecnologia.

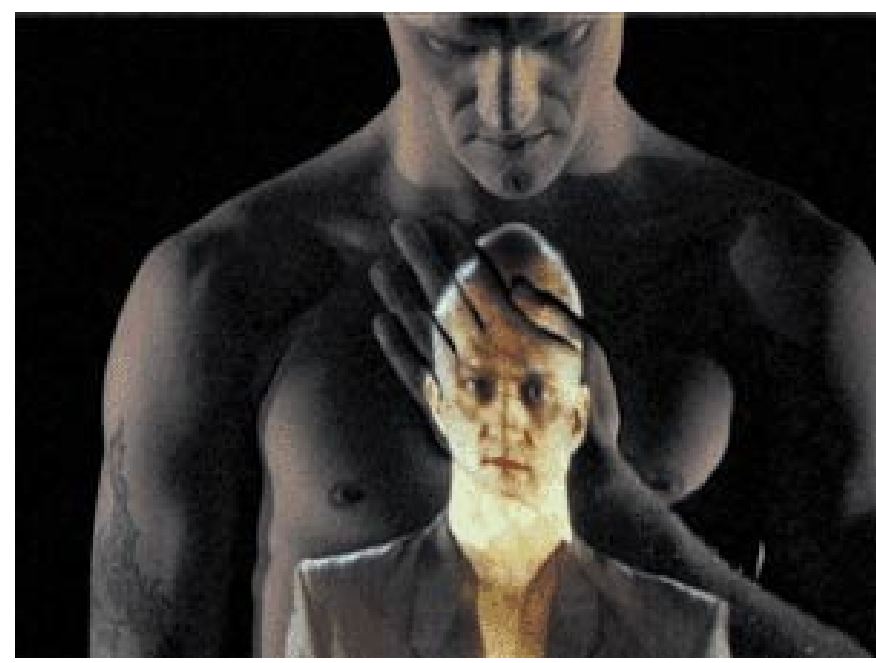

Fig.76 Cena da coreografia 'The Frozen Ones', de 2004

O trabalho 'The frozen ones' ${ }^{52}$ mostra uma curiosa relação com as imagens tecnológicas pois projeta imagem de cada bailarino em seu próprio corpo em tamanho real, de modo que todos os detalhes do corpo (olhos, boca, nariz e braços) são encaixados ao avatar digital projetado sobre o corpo, de forma que o efeito acaba causando vertigem pois, as ações mínimas de expressividade entre o bailarino real e o mesmo virtual projetado, se confundem e abrem para uma percepção sobre o duplo. As

\footnotetext{
52 Trabalho dos coreógrafos e bailarinos dinamarqueses Eva Ingemarssom e Niklas Ryden
} 
relações entre dança e novas tecnologias pontuam a história do corpo no espaço e no tempo e transcendem o contexto das mídias digitais e eletrônicas.

No cenário internacional, as décadas mais recentes também foram marcadas por essa confluência. O coreógrafo William Forsythe, diretor do Ballet de Frankfurt é uma referência importante desse processo. Ele incorporou a instalação 'Binary Ballistic Ballet', de 1995, do artista digital Michael Saup, na coreografia 'Eidos Telos', e também desenvolveu o CD-ROM 'Improvisation Technologies', em parceria com o ZKM - Museu de Arte e Mídia da Alemanha.

Outro trabalho de peso é o 'Ghoscatching', fruto de uma parceria entre Paul Kaiser, Shelley Eshkar (Riverbed Group) e o bailarino Bill T. Jones, que em seu produto final apresenta-se como uma instalação virtual de dança. A obra valeu-se do processo baseado no motion capture e nela trabalhou-se com sensores de luz (light-sensitives) colocados em 22 pontos do corpo do bailarino e oito câmeras que capturavam o sinal dos sensores no corpo que dançava no escuro.

Fig. 77 Cena da coreografia Mini@tures, do grupo francês Mulleras

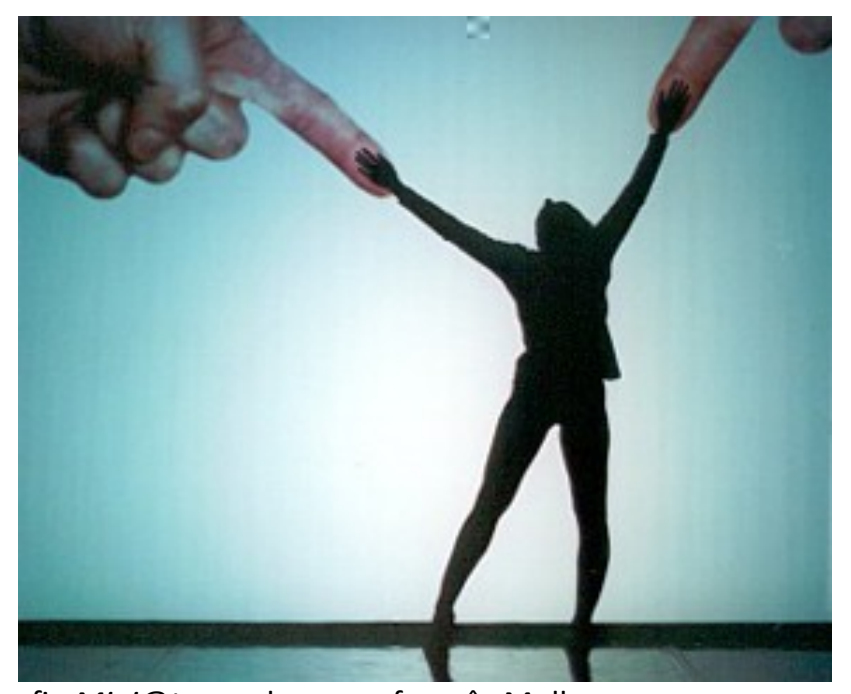

Nesse espetáculo, promoveu-se a interação, em tempo real, entre o movimento da bailarina, que interrompia o fluxo de conexão dos sensores, e as imagens e a composição, que eram reprocessadas e alteradas por sua participação. Paralelamente a esse trabalho, a bailarina Ivani Santana desenvolve ainda pesquisas particulares na área, buscando um tipo de corporalidade específica para a captura do vídeo e os processos de interferência na imagem em tempo real, utilizando softwares como o Image-ine, de 
processamento de imagens em tempo real, e o LifeForms, o famoso programa desenvolvido pela Simon Fraser University que teve Cunningham como primeiro usuário.

Realizado entre 1998 a 2001 e exibido nos principais eventos de arte e tecnologia do mundo, Mini@tures do grupo francês Mulleras (Fig.72), utiliza recursos da computação gráfica que mais do que produzir miniaturas de uma dança que pode caber na palma da mão, ampliam e refinam a discussão a respeito da relação da dança com as novas tecnologias. Isso porque não se limitam a utilizar novas mídias.

Antes, reinventam seus usos, permitindo assim novas construções de percepção, novas explorações para o movimento e novas organizações para o corpo no espaçotempo, que hoje se impõe conectado às dimensões virtuais das experiências desterritorializadas.

\subsection{Experiências brasileiras}

\subsubsection{As vídeo criaturas de Otavio Donasci}

Otavio Donasci é cenógrafo de teatro e produtor de eventos especiais, tornou-se conhecido no terreno da arte/tecnologia pelo seu projeto do videoteatro, primeiramente por meio de suas videocriaturas e posteriormente com de suas performances multimídia.

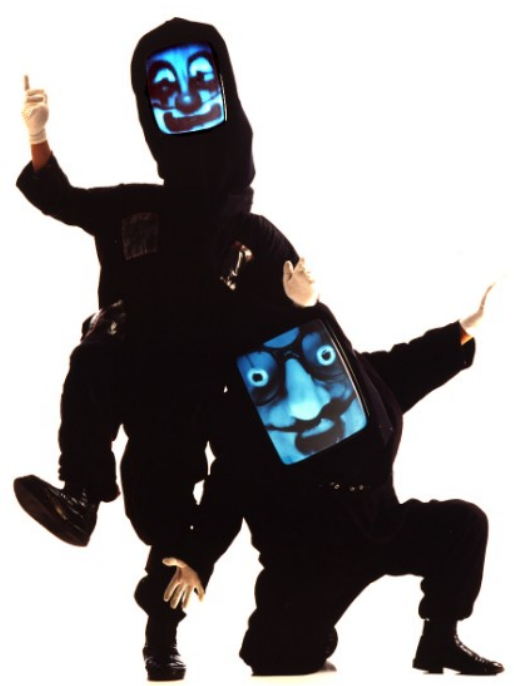

Fig.79 Proposta de videocriaturas de Donasci

A ideia básica da videocriatura era criar um híbrido, uma espécie de cyborg, metade gente e metade máquina, com um monitor de TV colocado, por meio de 
armações de plástico tubular (tubo PVC) moldado a quente, em cima de um ator escondido sob mantos pretos. Cada tela de monitor, ligada por cabos a um gravador de vídeo, nos mostrava a imagem de um rosto recitando monólogos ou dialogando ao vivo com o público ou com outras videocriaturas (Fig.74, 75 e 76). A proposta de Donasci é simples e precisa:

Ao vestir essa máscara eletrônica, sentiu meu corpo se deixar levar pelo comando desse rosto, como que tomado por outro ser, arrancando de mim expressões performáticas desconhecidas. Senti que formávamos, - eu e a imagem do rosto do ator fundida - uma terceira pessoa, híbrida de nós, diferente de nós, potencialização de nossas expressões e ao mesmo tempo estranho para nós. Chamei de videocriatura esse novo ser, uma espécie de 'Frankenstein' formado pela hibridização dimensional dessa máscara virtual no meu corpo vivo. Uma costura eletrônica. Sentia uma energia que vinha do rosto-tela direcionado pelo som, e que fluía direto até meu corpo sem minha interferência, comandando meus movimentos. Ficou claro desde o começo que esse ser pedia mais que a contemplação passiva de um vídeo ou espetáculo cênico: pedia uma relação física direta com o público. E a participação ativa do público já acontecia nas primeiras performances onde a Videocriatura avançava sobre a plateia, e tirava as pessoas para dançar um tango. Lembro-me bem que as pessoas se abandonavam nos braços desta criatura talvez devido a sentimentos confusos de medo e excitação. Um distanciamento brechtiniano novo e diferente me permitia assistir a performance de dentro desse ser, vendo as expressões assustadas e divertidas das pessoas como se não fosse comigo e sim com esse ser incorporado em mim. Trata-se de ampliar os recursos expressivos do ator com a incorporação da linguagem dos meios audiovisuais. (...) Quando o personagem morre, por exemplo, seu rosto vai aos poucos saindo de foco; quando ele está esbravejando contra o público, sua boca vai entrando num big close-up, através de uma zoom-in, até ocupar todo o rosto-tela. Ao mesmo tempo, o vídeo ganha a dimensão cênica do teatro, libera-se da fatalidade bidimensional e pode relacionar-se fisicamente com a platéia. Em síntese, o videoteatro faz uma espécie de "costura" eletrônica de vários recursos simbólicos, criando uma linguagem híbrida, que une as formas mais antigas de expressão da humanidade e as mais recentes. (...) ' $O$ Profeta' foi realmente a primeira performance concebida totalmente para uma videocriatura, coagulando as experiências de construção de protótipo, criação de rostos e expressão corporal num espaço não teatral. Ela foi o resultado dos primeiros laboratórios faciais que revelaram uma espécie de catálogo de possibilidades dessa nova linguagem, o Videoteatro. Na época, realizei longas sessões com Osmar di Pieri, ator versátil para esse começo de trajetória, com o qual explorei desde o texto clássico com inflexão teatral até sons guturais sem nexo, passando pela dublagem de cantores famosos do passado até uma versão do hino nacional brasileiro cantado de forma iconoclasta. Como um profeta apocalíptico pós-moderno, a primeira videocriatura, enrolada em panos pretos montados improvisadamente, descia aos gritos a rampa da Galeria de Arte São Paulo numa raiva santa que ia se transformando, se entristecendo, até chegar ao cínico, ao humorístico, à perplexidade e por fim, à morte quando seu rosto desfoca-se no meio do povo. A videocriatura usava cabo de transmissão de sinais de RF (rádio freqüência) e força que eram arrastados e enrolados pelo meu assistente na época, o performer Théo Werneck, de modo ostensivo e performático. Corporificar as experiências faciais transpondo o ritmo da edição de vídeo 
para as transições dos movimentos corporais foi o grande desafio desse primeiro trabalho. Descobri que a cumplicidade entre o movimento dos olhos no rosto eletrônico e a intenção do gesto no corpo era fundamental para a 'costura' entre os dois e condição número um para que a inusitada experiência flua da videocriatura para a plateia. (DONASCI, 2002, p.66-67)

Vários protótipos de videocriaturas foram experimentados. O mais antigo, que corresponde à descrição feita acima, é também o mais conhecido. Existem variantes, entretanto. O videofantoche, que utiliza um monitor de apenas cinco polegadas, imita perfeitamente um bonequinho de teatro infantil que se manipula com os dedos, com a diferença que eleva as possibilidades fisionômicas do fantoche ao infinito. Uma videocriatura enorme, que utiliza um monitor de 24 polegadas em cima de dois atores, foi mostrada em 1984 no Videobrasil.

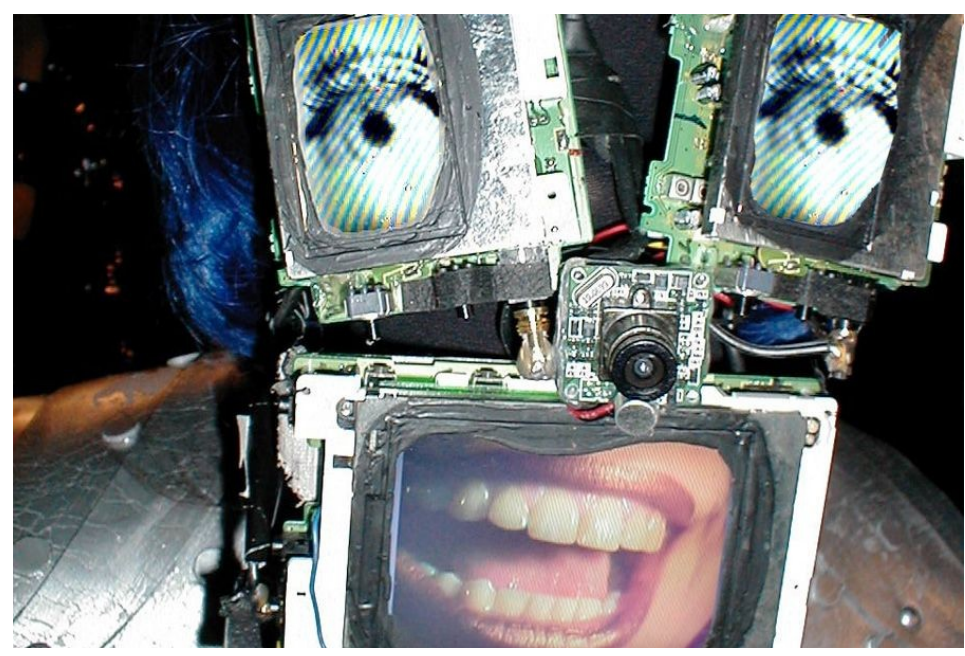

Fig.80 Proposta de videocriaturas de Donasci

Nesse mesmo festival, Donasci mostrou a mais importante inovação de seu projeto: a tomada e emissão simultâneas do rosto da criatura, condição fundamental para permitir a improvisação e o diálogo direto com a plateia. Donasci afirma:

Minha vocação para espaços não convencionais surgiu desde o início. Eu sentia que era importante a videocriatura estar no mesmo espaço que a plateia, interagindo diretamente com as pessoas. Apesar de funcionar muito bem num palco italiano, a criatura eletrônica brilhava mais quando disputava o mesmo espaço de um ser humano, tanto físico como emocional. Daí a terceira performance ser na rua, com a videocriatura perseguindo alguém. Nesta atuação, a videocriatura levava apenas um olho, gravado no lugar do rosto, e emitia sons guturais. Aquele ser inquietante, espécie de ciclope eletrônico, surgia de uma van, onde ficava o equipamento, e iniciava uma perseguição a um olho holográfico, pelo qual simulava uma paixão, um olho videografado atraído por um olho holografado. Ivan Isola, na época diretor do Museu da Imagem e do Som de São Paulo, fugia pelo centro movimentado da cidade de Curitiba, no Paraná, levando este olho desejado. Até que vencido ele o entrega 
ao apaixonado ser. A criatura-cíclope dirige-se então até um parlatório, numa região da cidade conhecida como "Boca Maldita", onde uma boca imensa surge em seu rosto-tela e passa a criticar as bocas que calam e não dizem o que sentem. Nessa época a criatura ainda requeria cabos de trinta metros e uma tomada de força. No entanto, a quarta performance, ainda no espaço público, celebrou a independência dos cabos e da força: videocassete e baterias surgiram acoplados à um cavalo montado por um vídeo-cavaleiro de olhos vazados, descendo uma ladeira de um quilômetro. (DONASCI, 2002, p.68)

As últimas invenções de Donasci são as chamadas performances multimídia que possibilitam ao videoteatro avançar ainda mais um passo. A ideia dessas performances são simples, mas o efeito final é poderoso. Por exemplo, na performance apresentada por ocasião da 20 a Bienal Internacional de São Paulo vê-se um ator contracenando ao vivo com a imagem de uma mulher projetada num telão.

Como esse telão foi confeccionado num tecido bastante elástico, a atriz que forneceu a imagem projetada pôde, ela própria, colocar-se atrás da tela e modelá-la com seu corpo, sem ser vista pelo público. A impressão que tem o público é que a imagem da mulher, projetada no telão, torna-se viva e tridimensional, permitindo ao ator real abraçá-la e até mesmo fazer amor com ela no palco. O mesmo processo foi utilizado também por Donasci, com maior radicalidade, na encenação da peça de Marcelo Paiva ‘525 Linhas', em 1989.

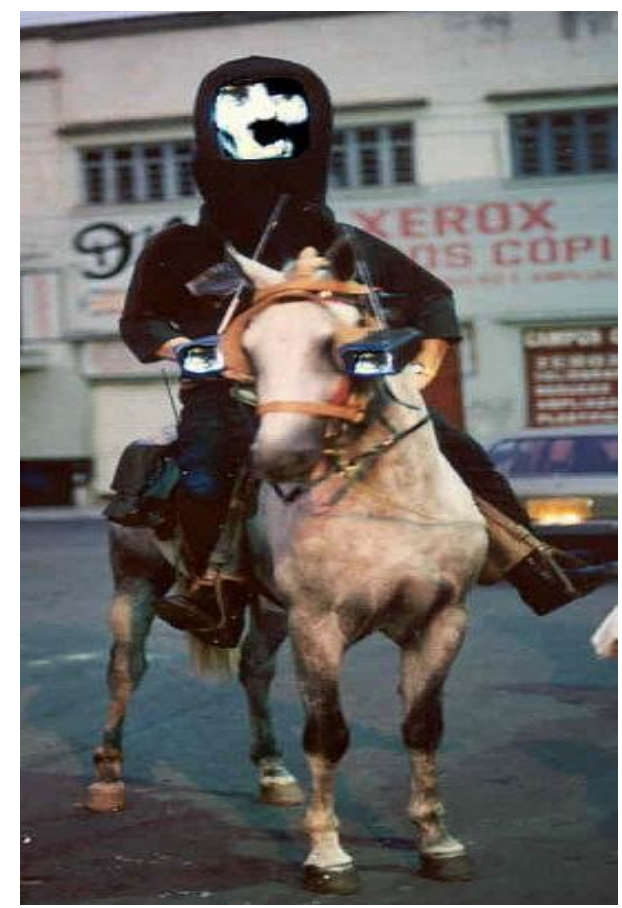

Fig.81 Proposta de videocriaturas de Donasci 
A cada nova experiência, Donasci destila o seu processo e avança na direção da síntese do teatro com as novas tecnologias. No Videobrasil de 1992, ele dá mais um passo nesse sentido:

\footnotetext{
Os rostos agora tridimensionais flutuam como velas no espaço, soprados por ventiladores montados junto com projetores em torres que se movimentam em cena, sobrevoando as cabeças dos espectadores, chocando-se com a platéia, simulando que os engolem. (DONASCI, 2002, p.73)
}

Donasci afirma seu lugar na seara das artes performativas brasileiras, bem como no diálogo entre corpo e tecnologia, em que as imagens tecnológicas não são projetadas, mas emitidas por televisores de toda ordem que assumem mais próteses, mais que máscaras criam um corpo híbrido entre o bufão, o performer, o técnico, o editor, o câmera e o público.

\subsubsection{Os rituais eletrônicos de Renato Cohen}

Artista multimídia, pesquisador das mediações e dos novos suportes na cena, autor de experimentos radicais. Xamanismo e redes telemáticas, o corpo mediado na rede e as narrativas projetadas na internet. Arte e interatividade, performance e tecnologia. Estas são palavras-chave, às quais poderíamos acrescentar, ainda, linguagens híbridas, cultura das bordas e tecnoculturas, que talvez ajudem a definir o perfil do artista, pesquisador e professor Renato Cohen.

O corpo do ator é um dos elementos fundamentais da expressão cênica e a forma como ele é trabalhado passa por transformações no contexto histórico. Deste modo, interage com o estilo ou movimento ao qual pertence, conjugando-se com os demais elementos da composição da encenação. Segundo Cohen 'a performance é antes de tudo uma expressão cênica'.

É neste sentido que se pretende situar o corpo na performance: no viés da expressão cênica, por entender que o artista plástico e o artista cênico concebem a utilização do corpo de maneira diferenciada, pelo percurso e interesse, próprios das linguagens. A forma com que o corpo se expressará, sofrerá transformações no contexto histórico, apesar de existirem certas discrepâncias na forma com que é trabalhado pelo ator. 
O corpo é contagiado pelas tecnologias e as mutações deste encontro são os novos questionamentos dos artistas que estão em face das hipóteses e reflexões sobre até que ponto pode-se chegar, se é que exista um ponto de chegada, ou seja, a polêmica causada é: quem gera a dinâmica de absorção e a pesquisa de que corpo é este. De acordo Lúcia Santaella

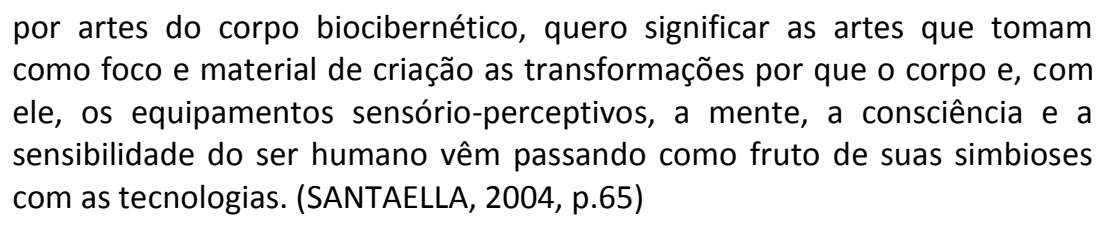

por artes do corpo biocibernético, quero significar as artes que tomam como foco e material de criação as transformações por que o corpo e, com ele, os equipamentos sensório-perceptivos, a mente, a consciência e a sensibilidade do ser humano vêm passando como fruto de suas simbioses com as tecnologias. (SANTAELLA, 2004, p.65)

Presentes em suas publicações, ementas de disciplinas e de linhas de pesquisa, em apresentações de obras artísticas e em catálogos de artistas contemporâneos brasileiros, elas podem, juntamente com os próprios veículos de sua produtividade, dar uma ideia de sua fértil e ousada carreira de artista vinculado à Universidade, desbravando fronteiras e avançando nos territórios de vanguarda.

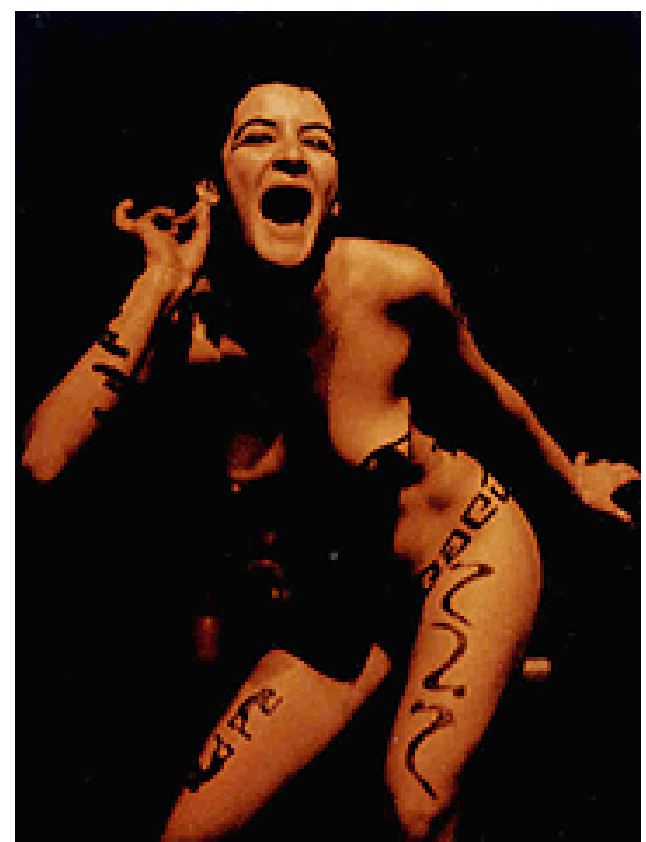

Fig.82 Cena da performance $K A$ - $A$ sombra da alma, de Renato Cohen

Na Unicamp seu vínculo inicia em 1998 em que atua como diretor do espetáculo KA - A sombra da alma (Fig.82), exibido no Museu da Cidade, em Campinas; e participa como docente da reestruturação do curso de mestrado e proposta de doutorado em Artes do IA, na linha de pesquisa interdisciplinar 'Arte e Mediação', orientando trabalhos de criação em artes cênicas. 
Suas aulas, no mestrado, eram laboratórios de experimentação, chamados por ele de 'seminários artísticos', perfil que leva também a coordenação das sessões do GT Grupo de trabalho 'Territórios e Fronteiras', da Abrace - Associação Brasileira de Pesquisa e Pós-Graduação em Artes Cênicas. Sua pesquisa articula as duas principais vertentes de sua obra, tratando da 'Performance na Era da Tecnologia'.

Nas suas próprias experiências radicais, como as performances interativas com uso do espaço computacional, conta com a parceria de Johannes Birringer (Ohio), autor da sala tecnológica que recebe inputs em tempo real - em contraposição à sala instalação, remetida às artes plásticas.

Finalmente, o conceito de environment que Renato Cohen formulou como energia psíquica presente na performance e veículo de troca, poderia nos auxiliar a entender como xamanismo e redes telemáticas aparecem juntos no elenco das palavraschave de sua obra. Tanto um como outro conectam pessoas, estabelecem redes de contato e convivência. É uma relação que se pode estabelecer na sua teoria, mas que soa, sobretudo, como seu desejo de conectar pessoas, mundos, idéias.

\subsubsection{A tecno-dança do grupo Cena 11}

O Grupo Cena 11 Cia. de Dança é uma companhia de formação e pesquisa em dança, situada em Florianópolis, Santa Catarina, e desenvolveu uma técnica que pode ser acessada por todos e está em constante diálogo com acadêmicos e pesquisadores interessados em suas ações. Três sólidos conceitos fazem parte da pesquisa do grupo:

- ética e estética sobre o corpo e o ambiente onde este corpo está inserido;

- produção unida à pesquisa artística, dança e tecnologia;

- e, mais recentemente, o intercâmbio de estudo e prática com outros grupos de arte e dança. 


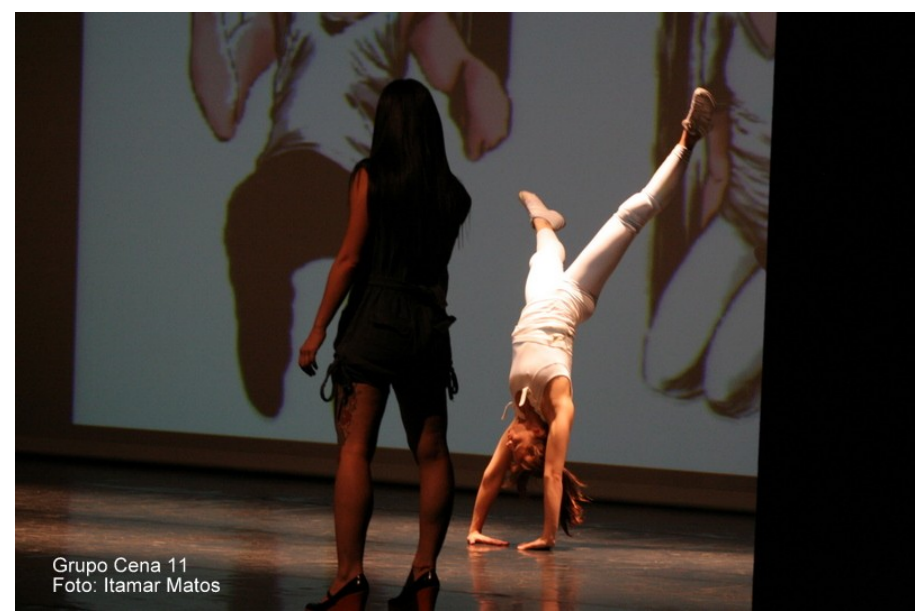

Fig.83 Cena do espetáculo 'Embodied Voodoo Game', do grupo Cena 11, de 2011

Esses conceitos podem ser observados em seus espetáculos 'Guia de Ideias Correlatas', 'Embodied Voodoo Game' (Fig.83) e 'SIM - Ações integradas de consentimento para ocupação e resistência'. Em uma de suas entrevistas o coreógrafo do grupo, Alejandro Ahmed, foi questionado sobre a função de recursos como patins, câmeras, projeções de slides e a importância dessas mesclas, ao que ele respondeu:

\footnotetext{
São extensões do corpo. Eles surgem de uma maneira circunstancial, mas também estimulados pelo pensamento que a gente está tendo. Como nossa dança é em função do corpo, tudo aquilo que seja necessário dar a ele para que consiga manifestar a idéia com mais propriedade, não temos pudor de usar. E claro que isso tem um tratamento estético vinculado aos créditos que damos para a coisa. (AHMED, 2003, p. 43)
}

As tecnologias compreendidas como extensões do corpo permeiam a construção artística do grupo. As tecnologias que são extensões do ser humano engendram modificações nas relações estabelecidas na organização social. Pense-se em uma extensão pontual, o vestuário. Certamente, o vestuário exerce a função de agasalhar, ou seja, o vestuário, como extensão da pele, pode ser visto como um mecanismo de controle térmico e como meio de definição do ser social.

Essas são idéias que parecem compreendidas pelo grupo mas o vestuário também interfere em outros meios e extensões do ser humano na sociedade, pois as extensões do ser humano são produtores de acontecimentos que modificam as relações estabelecidas socialmente.

A roupa é uma forma de manifesto não verbal que pode engendrar relações diante de sua utilização. A não-utilização da roupa diante de toda a carga de 
sensibilidade altamente visual e retorcida das sociedades industriais faz com que o contato visual com a pele possa ser algo chocante.

Nos espetáculos do grupo, a nudez participa da composição cênica. Em uma das cenas de Skinnerbox, um dos dançarinos da companhia entra nu e acoplado a seu corpo somente há um par de sapatos de palhaço vermelhos. Apesar de serem sapatos extremamente chamativos e provocantes, a atenção de alguns espectadores voltou-se para o fato de o corpo do dançarino estar nu, por isso causar certo incômodo. Sobre isso, o dançarino comenta:

Aquela cena do nu sozinho ali numa luz branca, o que tem ali de mais que chama a atenção deveria ser o sapato, que é vermelho, que é também um sapatão bem grandão. E às vezes, a pessoa está tão interessada, tão incomodada com a situação que ela de repente... ninguém falou do meu sapato vermelho. (ABRÃO ${ }^{53}, 2007$, p.34)

Assim, as utilizações de roupas que são extensões do corpo e que produzem acontecimentos engendram relações e sentidos ao corpo em si. O corpo que dança no Grupo Cena 11 vem dialogando com muitas das possibilidades de extensões criadas socialmente. Para muito além das roupas, equipamentos de tecnologia mais elaborados, como robôs, vêm compondo a organização cênica do grupo. As tecnologias são consideradas pelo grupo como forma de ampliar a maneira de comunicar.

\begin{abstract}
A perspectiva imediata para o homem ocidental, letrado e fragmentado, ao defrontar-se com a implosão elétrica dentro de sua própria cultura, é a de transformar-se rápido e seguramente numa criatura profundamente estruturada e complexa, emocionalmente consciente de sua total interdependência em relação ao resto da sociedade. (MCLUHAN, 2005, p. 69)
\end{abstract}

Sabe-se que muitas das extensões possíveis são consideradas possibilidade para a autonomia do ser humano diante da organização social. Assim, muitas das extensões produzidas socialmente adentram a produção artística do Grupo Cena 11. O diálogo com essas extensões vem carregado de múltiplas possibilidades e, no particular da arte do Cena 11, em muitos momentos, as extensões recebem destaque frente à organização da arte do grupo.

Como ilustra a análise do espetáculo 'SKR - Procedimento 01', o tratamento estético dado à tecnologia pelo grupo, em alguns momentos, parece ressaltar as

\footnotetext{
${ }^{53}$ Elisa Abrão, Mestre em Educação Física pela Universidade Federal de Santa Catarina na linha de Teoria e prática pedagógica, em seu artigo 'As relações entre arte e tecnologia: a dança híbrida do Cena 11', publicado na 'Revista Pensar a prática' da UFG - Universidade de Goiás
} 
tecnologias em si. No espetáculo em questão, do total de 25 cenas, apenas 12 não apresentam o uso de equipamentos tecnológicos, quatro são somente constituídas por equipamentos tecnológicos e nove consideram-se mistas, as quais compostas por dançarinos e equipamentos tecnológicos. Os indicadores mostram o número de 13 cenas, nas quais estão presentes equipamentos tecnológicos e um número menor, 12, sem a presença deles. Na arte do Cena 11, esses dados indicam uma possível analogia entre o universo tecnológico e o artístico.

Além da presença marcante das tecnologias na arte da companhia, a busca por um corpo eficiente para realizar a técnica corporal desenvolvida pelo grupo parece fortalecida pela utilização das tecnologias. O entusiasmo diante das tecnologias, na crença da superação dos limites físicos, principalmente diante das possibilidades das tecnologias digitais, parece florescer na arte do Cena 11. Esse entusiasmo é observado em muitas das relações humanas atuais. A eficiência das tecnologias digitais parece ter fortalecido sua utilização ou ser a argumentação para fundar seu predomínio em nossa sociedade.

De uma tecnologia de base física, como a analógica, que na execução de trabalhos ou no gozo do lazer demandava de homens e mulheres habilidades, destrezas físicas, treináveis ao longo da vida, passa-se para uma nova e desafiadora situação em que a demanda se volta a qualificações mentais, à capacidade de abstração. (BIANCHETTI,2001, p. 13)

Assim, as relações do seres humanos com as tecnologias modificaram as exigências de qualidades humanas para tal relação ocorrer. Parece que a pretensão do grupo é a utilização da tecnologia cada vez mais automatizada. Como comenta uma das integrantes do grupo:

Agente trabalha meio no que o Álvaro chama de tecnologia do artesanato. A gente gostaria muito que as estruturas se movimentassem em cima das pessoas (risos), mas não é uma realidade tão próxima. (ABRÃO, 2007, p.34)

O grupo parece entusiasmado diante das possibilidades tecnológicas e de toda a eficiência existente em tal universo. Uma grande questão para o grupo é o acesso ainda ser restrito às tecnologias, situação também enfrentada por relevante parte da sociedade, que busca interminavelmente mais qualidade tecnológica. 
se coetâneos (as) ao seu tempo, a rever formas, métodos de ensinar e aprender - na escola e no trabalho -, uma vez que a tradição, a experiência e a formação/treinamento pontual deixaram de ser critério de qualificação para a vida/trabalho. (BIANCHETTI, 2001, p. 13)

Isso, em certa medida, pode ser observado na arte do Grupo Cena 11. Apesar do grupo em questão ter um treinamento físico específico, até mesmo por se tratar de dança na qual o corpo, até o momento, se faz necessário para ela ser realizada, parece que também as tecnologias vêm adentrando suas produções e criando novas relações e métodos para o universo da dança.

Assim, os saberes desenvolvidos nas áreas tecnológicas tornam-se tão necessários quanto os artísticos, apesar dos limitantes financeiros. Ilustra essas relações entre o universo artístico e tecnológico na arte do grupo a fala de uma de suas dançarinas:

\footnotetext{
Eu sei que dentro do que a gente pode estar fazendo estamos fazendo o melhor que a gente consegue. Mas eu gostaria que fosse melhor, pois acho a coisa ainda muito devagar. 0 robô podia ser (...) se tivesse alguém dessa área trabalhando junto, desenvolvendo, seria melhor. Não que ele esteja ruim, mas eu tinha na minha cabeça [que], se a gente tivesse mais dinheiro pra comprar o nosso projetor, a nossa luz, essa coisa tecnológica seria sempre a mesma, sempre seria a mesma qualidade de imagem, mas como a gente tem que locar o projetor em cada espetáculo, então, tem cidade a que tu chegas, olhas daquele jeito a definição. Então, eu acho que a gente podia construir mais, se tivesse uma sede, um lugar pra deixar tudo montado. la partir pra um outro lugar. (ABRÃO, 2007, p.34)
}

Demonstra-se a vontade do grupo de desenvolver e ampliar essa relação com as possibilidades tecnológicas, tanto pelo desejo de adquirir os aparatos tecnológicos quanto de contratar um especialista na área. Assim, compreendemos que a Companhia Cena 11 almeja o que, de certa forma, é pretensão vigente em nossa sociedade: que as tecnologias digitais predominem sobre as analógicas. A grande vantagem da linguagem binária está no maior diálogo entre os aparatos tecnológicos, que possibilita encurtar espaço e tempo, além de oferecer uma automatização tão desejada.

As tecnologias fazem parte da história da humanidade, e não se quer negá-las, mas se acha necessário que o entusiasmo diante de todos esses avanços seja crítico, capaz de compreender as contradições presentes no desenvolvimento das tecnologias. Deve-se não tê-las como imprescindíveis para o ato de dança, mas sim como possibilidade de ampliar algumas relações que estabelecemos com o mundo enquanto dançamos. Entretanto, elas podem, em alguns momentos, limitar o fazer artístico. A 
utilização da tecnologia na dança soa como algo natural, nas palavras de um dos integrantes da Companhia:

\begin{abstract}
Eu acho que, desde que surgiu essa tecnologia, ela já começou ser usada pela arte. Isso tem a ver com o trânsito entre ciência e arte. Então, esse trânsito sempre ocorreu de uma forma ou outra. Sempre houve cientistas interessados em arte e artistas interessados em ciência, e esse trânsito, de alguma forma, sempre em algum ponto, convergiu para que se produzisse algo. Então, tem uma tendência pra o quanto a tecnologia evolui, e os modos de produzir arte também se diferenciam. (ABRÃO, 2007, p.34)
\end{abstract}

Assim, a ciência parece validar a arte por meio da tecnologia, legitimação em certa medida necessária, em um mundo cada vez mais tecnocrata, onde a ciência valida verdades e determina comportamentos. A presença das tecnologias na vida das pessoas e no universo da dança passa despercebida com o decorrer do tempo, pois o maior uso e a maior quantidade de aparatos levam à naturalização dela. Uma das dançarinas mais antigas do grupo comenta que:

Desde o primeiro espetáculo que a gente fez, já tinha microfone, música ao vivo. O Álvaro sempre pensou desse jeito, então, é uma coisa que não surpreende mais. Dizer tem vídeo é igual a dizer tem uma roupa, está normal [...] tá bem incorporado assim. (ABRÃO, 2007, p.34)

Assim, as tecnologias, como vídeo, são compreendidas pelo grupo como tão construtoras da arte quanto o ato de dançar, semelhantes às tecnologias que já passam despercebidas, como roupas, iluminação. Tal compreensão parece firmar a hipótese de compreensão da relação de diálogo entre o universo tecnológico e artístico pelo grupo.

A tecnologia, de forma geral, permeia a vida das pessoas, como também as relações interpessoais, não estando ausente nas artes. A presença das tecnologias na vida das pessoas e no universo da dança aparece de forma concreta na arte do grupo, e muitos recursos tecnológicos dele já se dissolveram e passam despercebidos. Para questionar as diversas funções assumidas na utilização das tecnologias acopladas ao corpo na arte do Cena 11, apresento uma reflexão de Tomaz Tadeu da Silva ${ }^{54}$ :

As tecnologias ciborguianas podem ser: 1. restauradoras: permitem restaurar funções e substituir órgãos e membros perdidos; 2 . normalizadoras: retornam as criaturas a uma indiferente normalidade; 3. reconfiguradoras: criam criaturas pós-humanas, que são iguais aos seres humanos e, ao mesmo tempo,

\footnotetext{
${ }^{54}$ Tomaz T. Silva é Ph.D. pela Standford University, 1984, atualmente é professor colaborador do Programa em Pós-Graduação em Educação da Universidade Federal do Rio Grande do Sul
} 
diferentes deles; 4. melhoradoras: criam criaturas melhoradas, relativamente ao ser humano. (SILVA, 2000, p.14)

A arte do Grupo Cena 11 é permeada por muitas dessas possibilidades citadas por Silva no uso das tecnologias. Percebemos que muitas das intervenções, modificações sobre o corpo, que vêm ocorrendo, sobretudo na modernidade, justificam a denominação pós-humano, mas se questiona se, ao fazer isso, não se estaria negando o próprio caráter histórico do humano.

Spanghero ${ }^{55}$ utiliza o termo "pós-humano" para referir-se aos dançarinos do Cena 11, aproximando-os da idéia de hologramas, na descrição da coreografia Violência. A autora corrobora a idéia proposta por Tomaz Tadeu da Silva, ao usar esse termo, pois acoplados aos corpos dos dançarinos da companhia estão: pernas e braços metálicos, bogobol, patins, separador bucal, botas, joelheiras, dentre outros recursos.

Essas peças artificiais tornam seus corpos mais altos, mais fortes, amplificados, assimétricos, capazes de pular, virar míssil e se arremessar. As próteses lhes garantem superpoderes e com elas sua dança é feita. (SPANGHERO, 2003, p.94)

Como a história do coreógrafo permeia profundamente a história do grupo, e sabendo que ele "superou" uma doença genética por meio da dança, pode-se compreender a tecnologia tanto como normalizadora quanto restauradora. Na dança do Cena 11, o que é entendido como imperfeições são os limites da materialidade corpórea, ao passo que as tecnologias são vistas como possibilidades, como, por exemplo, as próteses que ampliam a potência do corpo. Englobam-se as possibilidades reconfiguradoras da tecnologia, para criar criaturas melhoradas, relativamente ao ser humano, ou seja, mais ágeis e fortes, dentre outras características.

\footnotetext{
${ }^{55}$ Maíra Spanghero é Doutora em comunicação e semiótica, professora da PUC/SP e autora do livro 'A dança dos encéfalos acesos' (Itaú Cultural, 2003)
} 


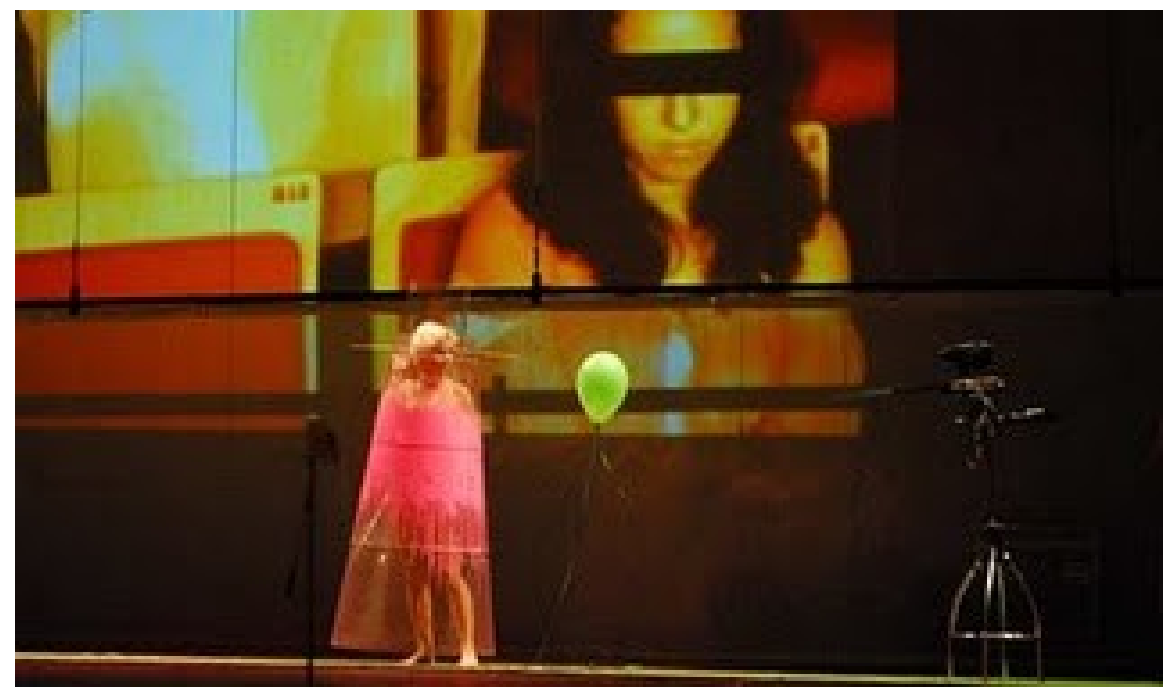

Fig.84 Cena do espetáculo Skinnerbox, do Cena 11, em 2009

Para o espetáculo Skinnerbox (Fig.79, 80 e 81) foram desenvolvidos acessórios que distendem o corpo para ele mais bem lidar com o ambiente, de forma a ampliar a qualificação na preparação técnica, e isso parece aproximar as tecnologias ciborguianas como melhoradoras. Constituem criaturas melhores relativas ao ser humano, com o uso dos artifícios que determinam uma amplificação inusitada das capacidades humanas e a busca por lidar bem com o ambiente.

Como existe a busca por certa adaptação e preservação na temática do espetáculo Skinnerbox, a tecnologia vem funcionando, ao mesmo tempo, como normalizadora e melhoradora da relação indivíduo-ambiente-indivíduo. É necessário refletir sobre se essa condição, atrelada à idéia de superação na sociedade hodierna, permeada pelos ideais da ciência, leva em conta que a própria tecnociência criada pelo capital vem sendo responsável pela deterioração dessa mesma relação. Importante é ressaltar que as melhorias e o progresso não necessariamente garantem que seremos mais felizes, porém, engendram relações ambíguas entre os seres humanos, que necessitam ser tratadas conscientemente.

A função que a tecnologia desempenha na dança do Cena 11, para vencer os limites corporais, compreendida como superpoderes ao ampliar potências, parece permeada pela idéia de progresso. Na ciência, em especial, no âmbito das ciências biomédicas, a máxima moderna de que tudo que é possível deve ser feito faz-se presente e é permeada com sua pretensa neutralidade, objetividade e eficiência. 


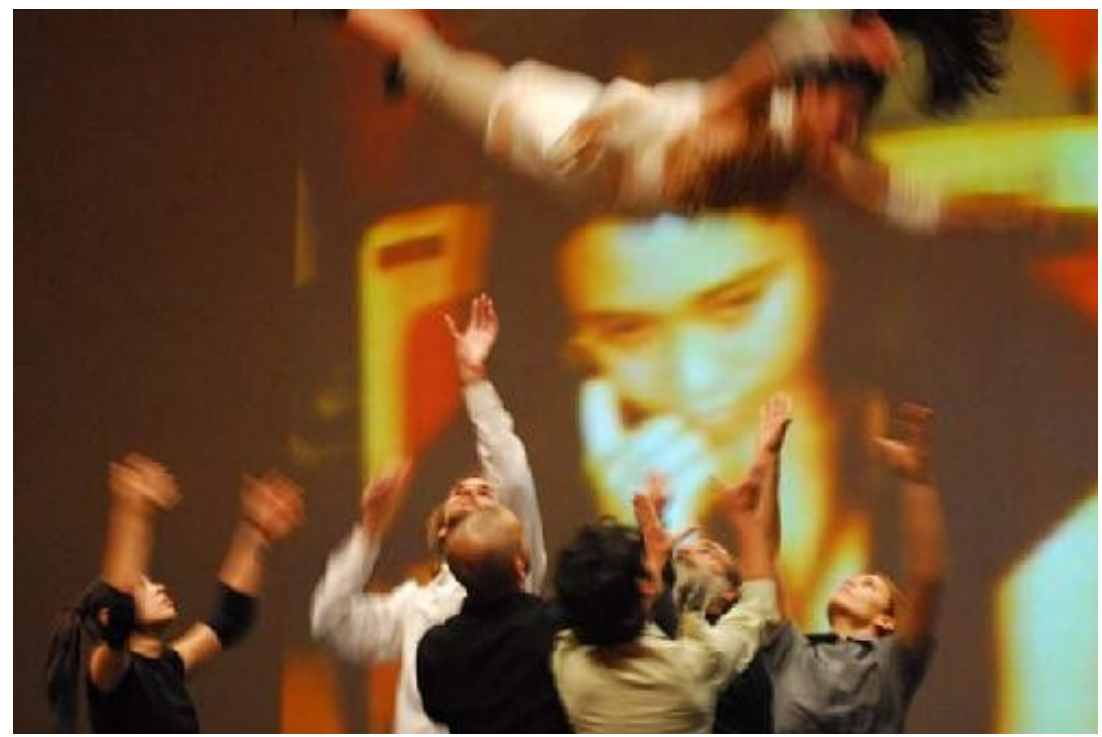

Fig.85 Cena do espetáculo Skinnerbox, do Cena 11, em 2009

Indústria e ideologia são voltadas a esse trabalho, subsidiadas por uma ciência e uma tecnologia que, concomitantemente, desprezam os limites da materialidade e exaltam a noção moderna do indivíduo livre, baseada na ambígua e perigosa crença de que se pode ter o corpo que se quer (...) A reconstrução e reestruturação do corpo presentes no processo civilizatório e as modificações corporais extremadas contemporaneamente permeiam a dança, como uma manifestação artística que acompanha a humanidade em sua trajetória. Na dança, esse processo ocorre, e todas essas práticas sociais que se propõem a ser uma intervenção sobre o corpo têm como fundamento, em maior ou menor grau, os conhecimentos produzidos pela ciência e, em especial, pelas ciências biomédicas. (SILVA, 2001, p. 5-62)

O grupo compreende as tecnologias como algo que possibilita a superação dos seres humanos diante dos outros animais, assumindo a influência da teoria evolucionista em sua produção, são idéias que permeiam a construção artística do grupo. Como comenta um dos integrantes do grupo:

É essa coisa, até que o Álvaro fala: a lança, o homem é bem mais frágil que um urso, por que que a gente evoluiu bem mais que o urso? Por esse nosso fascínio de conseguir fazer coisas que vão estender a nossa força? A gente não conseguia correr que nem um leopardo daí a gente fez o avião, o que foi que a gente adaptou, pra nossa sobrevivência? (ABRÃO, 2007, p.34)

Com essa perspectiva, os integrantes do Cena 11 põem o próprio desenvolvimento das tecnologias na busca por fortalecer os humanos, tornando-os assim mais adaptados diante dos outros animais e garantindo sua sobrevivência. As relações entre ser humano, tecnologia e outros animais estavam colocadas no espetáculo Skinnerbox, como comenta um dos dançarinos sobre o espetáculo:

Me chamou a atenção por trabalhar com um ser que é a Nina, bem primitivo, bem eficaz, é claro, porque foi feito um trabalho ali com ela, e um robô que é 
bem futurístico e o homem. Essa relação é muito interessante. O homem tá dominando as duas coisas. Tem algum momento que tu podes até viajar que o cachorro domina, que também domina ele. Tá ali, ele também te impede algumas coisas, se não estivesse, tu poderias fazer, mas quem manda ali é o homem, sempre vai mandar. É o homem, independente, a máquina. Ah! O homem que pensou aquilo ali, ele evolui mais que a máquina pra fazer a máquina. Eu não posso ficar inferior à máquina. Como construir uma coisa inferior a ele?[...] O homem só pode ser destruído por ele mesmo. Só homem destrói outro homem, não vai ser a máquina que vai destruir um homem. (ABRÃO, 2007, p.34)

Assim, se reafirma a máxima moderna do homem como senhor da natureza. 0 projeto científico ocidental parece ter a dominação em sua essência. De certa forma, isso ocorre com os próprios seres humanos envolvidos nesse contexto, tendo de ter controle sobre os animais, sobre as máquinas e sobre si próprios, em suas relações mais intrínsecas, como as sensações de medo, dor, vaidade para sobreviverem como dançarinos do Grupo Cena 11.

São relações de domínio humano sobre a natureza no controle da existência dela, e essa existência, sendo relativa à existência humana, pode ser observada pela presença de Nina na arte da companhia. Em uma das observações de treino, uma dançarina comentou que "Nina foi comprada com mais dois cachorros, e ela foi a escolhida como a mais capaz, que reuniu as qualidades para a função". Isso deixa claro que a Nina existe no grupo por essa finalidade. As qualidades para a função de dançar no grupo foram alcançadas pela cachorra, "que durante dois anos passou por um treinamento com adestrador". Ainda sobre o cachorro, a dançarina comentou que tem de educar o cachorro e o dono do cachorro, para não perder o treinamento.

O grupo parece resumir, em alguns momentos, a existência da cachorra às necessidades do próprio grupo. Demonstrou, em muitos momentos, a não-importância da cachorra como ser vivo em si, ressaltando apenas as funções que ela realiza no grupo. Acerca do Cena 11, o coreógrafo comenta:

Vejo o corpo como um aparato tecnológico (tecnologia = técnica aplicada). A relação com a tecnologia já vem em criar uma técnica ou utilizar uma técnica para alguma coisa. Ballet clássico ou jiu-jitsu (técnicas) transformam-se em tecnologia quando são aplicados para, por exemplo, criar dança contemporânea. Óbvio que isso se estende para as relações que o Cena 11 tem com o vídeo, slides (...) mas não acho que aí está o nosso forte em tecnologia; isso é o que as pessoas em geral entendem por tecnologia - que é um conhecimento muito pequeno. Não sentimos que o sapato é uma tecnologia, o corpo se adaptou ao sapato. Andar de sapato é uma técnica. E dança é ciência. (AHMED, 2003, p.42) 
Essas idéias do coreógrafo possibilitam reflexões importantes para compreender a arte do grupo. Inicialmente, entender o corpo como um aparato tecnológico parece resumi-lo a um objeto que executa técnicas aplicadas, além de reforçar uma concepção dualista de ser humano.

Contraditoriamente, essa idéia pode restringir o próprio ser humano e a dominação da natureza atrelada à tecnologia, tal como ocorre desde os primórdios da modernidade, e parece se reafirmar na dominação do corpo que dança no grupo Cena 11. A natureza deixou de ser objeto de contemplação para ser explorada por saberes e práticas sociais.

A idéia de humanidade que não se contrapunha à natureza e que se entendia como parte dela parece ter sido abandonada. A concepção que fundamenta a tecnociência há muito já mostrava estabelecer as relações entre sujeito e objeto como parâmetros matemáticos. Cabe refletir se essa concepção não permeia a arte do grupo em questão, sobrepondo-se a outras concepções e características antes associadas ao universo da arte.

Em um dos treinos observados, o coreógrafo comenta como os integrantes do grupo teriam de se sentir como uma porta e cair, e não usar outro estímulo, simplesmente cair como uma porta. O coreógrafo comenta a ideia de configurar o corpo rápido nas pequenas quedas para agüentar quedas maiores.

A arte do grupo parece corroborar a idéia do dançarino, de um objeto que realiza a ação. A tecnologia que parecia ser um dos motes da arte do grupo apresenta-se como continuação dos pensamentos que constituem sua técnica corporal, na qual compreende o corpo como objeto que processa informações, como comenta uma das integrantes do grupo:

A tecnologia tá na maneira de produzir um movimento, [...] a gente trabalha com robô, a gente trabalha com [...], mas nada disso é tecnologia de ponta, isso é uma maneira de ampliar a tecnologia do corpo. (ABRÃO, 2007, p.34)

O corpo parece entendido como objeto, afirma-se como um dos aparatos tecnológicos da dança prevista. A separação entre sujeito e objeto parece estabelecer relação com a arte do grupo, engendrando conseqüências ético-políticas de grande importância. A separação entre sujeito e objeto é considerada característica típica da 
racionalidade científica moderna, que se apresenta indispensável à objetividade científica.

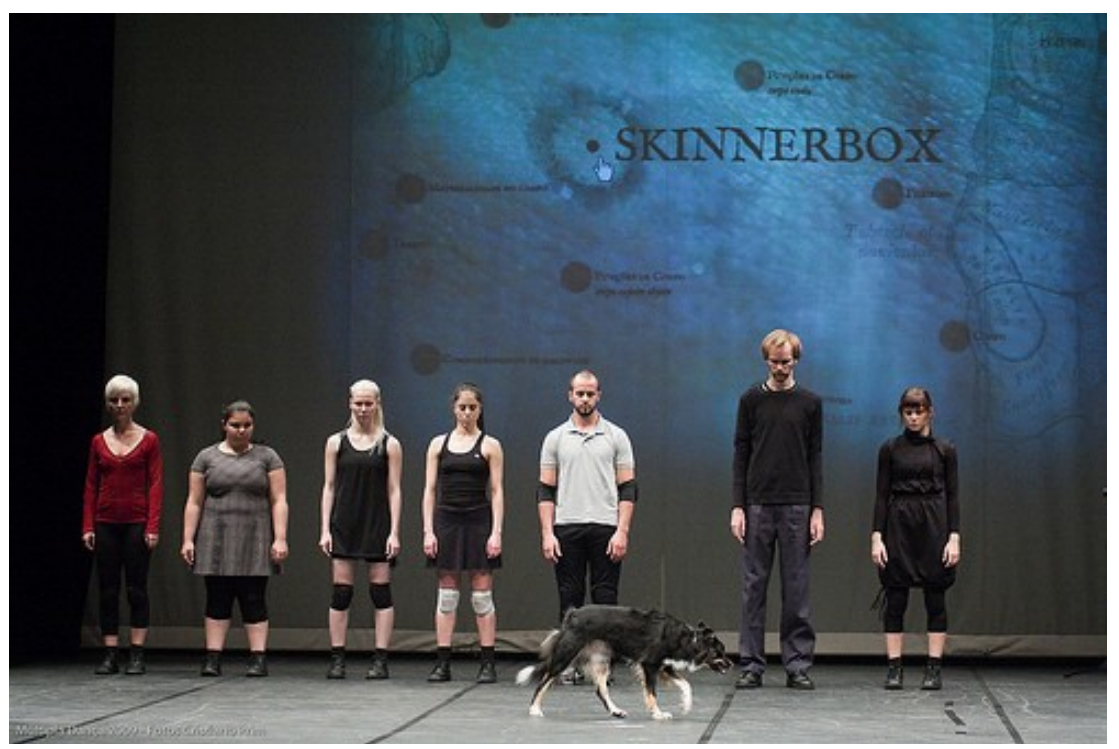

Fig.86 Cena do espetáculo Skinnerbox, do Cena 11, em 2009

O afastamento do objeto não possibilita que o ser humano se reconheça no objeto, em nome da tão famosa objetividade científica. A extrema separação não parece possível e, com isso, o sujeito não se reconhece mais como tal, pois acaba tendo uma relação a serviço da exploração e dominação da natureza.

\footnotetext{
Delineia-se já aqui uma espécie de paradoxo em termos lógicos, o distanciamento infinito do sujeito com relação ao seu objeto não constituiria uma objetividade absoluta, mas simplesmente a perda [dele]. (...) Em nossa sociedade, esse distanciamento não parece ter limite, e juntamente com o desenvolvimento das forças produtivas, esse paradoxo se expressa, em termos político-existenciais, na alienação, na coisificação generalizada. $O$ desvario universal é, ao mesmo tempo, o seu produto e a condição propícia para o seu florescimento. (DUARTE, 1988, p.115-117)
}

Parecem existir algumas contradições referentes ao entendimento de tecnologia e técnica, além das já discutidas de corpo como aparato tecnológico. A dança é constituída por técnicas corporais, seja de ballet ou jiu-jitsu, dentre outras, e utilizar outras técnicas não a transforma em tecnologia, e sim coloca novas possibilidades de técnicas corporais para o ato de dançar.

A própria utilização de equipamentos e recursos nas movimentações exige determinadas técnicas específicas para realizá-las. A ideia fomentada pelo grupo de que andar de sapato é uma técnica parece correta. Andar é técnica e concorda-se com que andar de sapato é a técnica de andar de sapato, pois o aparato influencia a própria 
técnica corporal executada. O grupo, porém, entende que o sapato não é uma tecnologia pois percebe que o corpo se adaptou a ele.

Essa adaptação naturaliza para o grupo o aparato tecnológico, considerando-o pertencente à natureza humana. Frente a isso, questiona-se: Se o sapato não é uma tecnologia, por que o corpo que dança o seria? O corpo desenvolve técnicas e, por isso, é considerado um aparato tecnológico para o grupo, e por que o sapato, no qual o ser humano aplica técnica, não é tecnologia? Ainda, questiona-se a utilização do conceito de aplicar, referente às técnicas corporais que podem ser realizadas para o ato de dançar, visto que possivelmente o conceituado executar seria o mais correto. Assim, questionase: se as técnicas de jiu-jitsu e balé clássico fossem utilizadas para andar ou dançar isso as transformaria em tecnologia?

Percebe-se que não existe limiar que possibilite classificar a tecnologia utilizada na dança como boa ou ruim. Entrementes, encontram se relações ambíguas, apresentando questões que merecem atenção, frente à grande valorização do uso da tecnologia no universo artístico com pouca reflexão. Muitos argumentos sustentam-na como pertencente à noção de progresso, o que já permite questionar uma apologia ao presente e um esquecimento das tradições.

A utilização da tecnologia nas produções artísticas é uma das formas pelas quais o ser humano se distancia de uma simples imitação da natureza. Essa concepção de ser humano entendido como um aparato tecnológico parece ser uma negação a tudo que remeta à natureza humana. Essas ideias parecem corroborar o que aponta Huisman sobre uma nova perspectiva de arte, na qual:

\footnotetext{
Quanto menos ela é natural mais é artística. Uma obra de arte tem necessidade de ser sobre-real para poder ser autêntica. Se a pintura é de extrema monotonia é porque constitui uma imitação servil da natureza. A arte digna desse nome abstém-se de tomar por tema o pôr-do-sol no Adriático ou a pequenez do homem face ao mar Antárctico. Porque ela se sente nesse ponto tão inferior à própria Natureza que não teria nenhuma vantagem em rivalizar com Deus. (HUISMAN,1994, p.75)
}

A arte contemporânea é influenciada por seu tempo, no qual as tecnologias, com as mais diversas funções, permeiam-na. A utilização de tecnologias na arte vem se apresentando como tendência, e o Cena 11, de forma geral, é compreendido como um dos grupos que mais inovam no universo da dança. A grande influência do Cena 11 nesse 
universo coloca-o em um lugar de destaque, tornando-o capaz de ditar e reforçar tendências presentes no universo artístico da dança.

\subsubsection{Outras experiências brasileiras}

Como temos visto são inúmeras as possibilidades de uso das imagens tecnológicas junto ao corpo, nas funções de ampliação, distorção e novos entendimentos poéticos acerca de um corpo que pode agora ser fragmentado, editado e projetado em superfícies múltiplas; assim alcançando novos entendimentos somente pelo suporte onde a imagem esta projetada.

Analisei dois exemplos dos quais participei como diretor ('Devorando Quixote', de 2008 - Fig.87) e como diretor de arte ('Devorando Fausto', de 2008). No primeiro exemplo, usamos a imagem de um skyline do mar, a partir de uma praia, com ondas e imagem colorida, como metáfora de transcendência no espetáculo, essas imagens com som natural eram sempre utilizadas, porém a forma como estas imagens surgiram (que aqui eram como um lite motive do espetáculo) foi em encontro ao que neste capítulo abordo, o uso do corpo como suporte ou do corpo como imagem alterada pela projeção.

O personagem Quixote, interpretado por Sergio Khair, tem sua armadura medieval aberta pelo personagem Alice (Carol Pinzan), que como num oratório, abre a armadura e se vê projetada no peito do ator, com a imagem com áudio do oceano, e depois ao fechar essa imagem passa para três telões gigantes, ampliando o sentido poético do "mar interno" do personagem que se inicia no corpo (peito) e abre-se até as telas. 


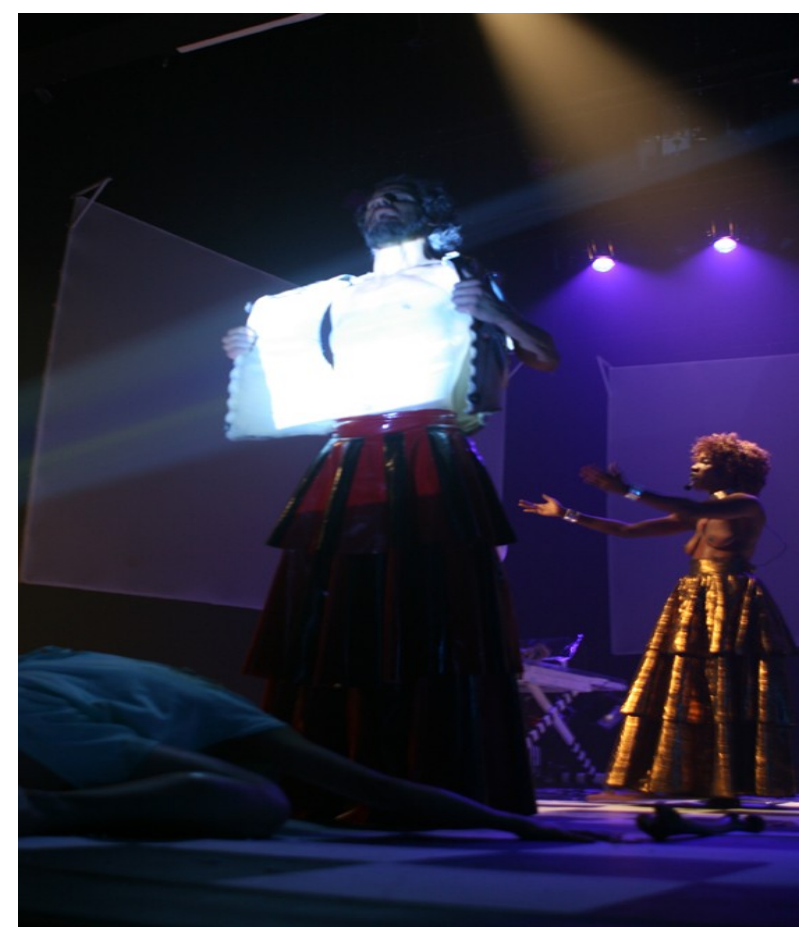

Fig.87 Cena de 'Devorando Quixote', de 2008

Em outro momento um dos personagens "engole" uma microcâmera que era usada para gravar pequenos detalhes de uma cena feita com bonecos minúsculos, o ator engole a câmera que por ter recurso de infra vermelho, mostra todo o interior e o início da garganta do ator que é projetado em três telas. O público vê a atuação do ator que se move lentamente com o corpo todo pintado de azul, mas também tem a dimensão do que ocorre dentro de sua boca, detalhando dentes, língua e saliva, imagens que eram editadas e saturadas em tempo real por Vjs.

Tomo como base uma cena em que o diretor italiano Romeo Castelucci usa no espetáculo 'Julio Cesar' (Fig.83) em que um ator engole uma câmera de endoscopia, e nas telas em cena se vê a movimentação das cordas vocais do ator funcionando, ou seja a palavra-texto shakesperiana dita, pode ser vista também sendo realizada pelos movimentos das cordas vocais; o que amplia a ideia de palavra já que vemos como ela se forma na garganta do ator.

No segundo exemplo de ampliação do corpo pelas imagens tecnológicas, cito uma cena do espetáculo 'Devorando Fausto', com direção de Marcos Bulhões, em que numa cena intitulada 'Guerra Santa', realizada dentro de uma capela do Forte dos Reis Magos, um performer caracterizado de Jesus Cristo, corta com um bisturi cirúrgico a pele sobre seu coração, numa alusão clara a iconografia das imagens bíblicas. 


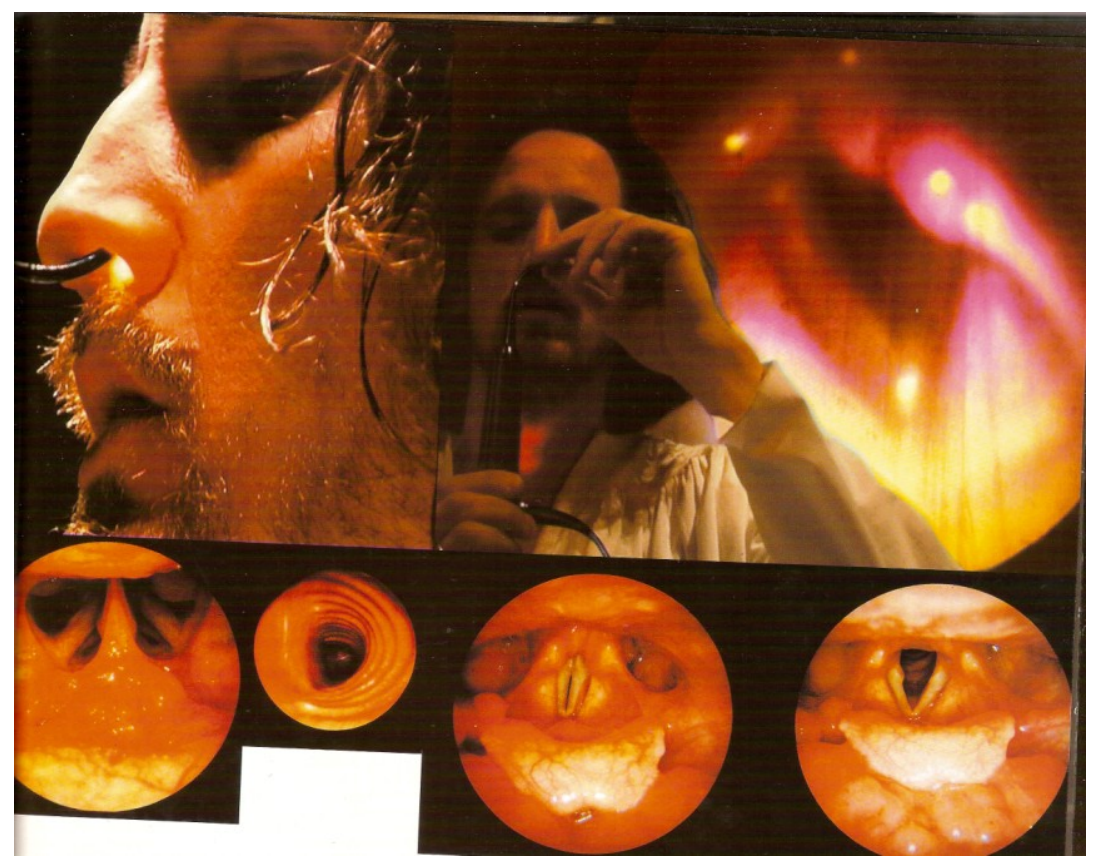

Fig.88 Cena de 'Julio Cesar', com a Societas Raffaello Sanzio com direção de Romeo Castelucci, em 1997

Com o corte e o escorrer do sangue real do performer, uma câmera grava ao vídeo a cena que é simultaneamente projetada no telhado branco da capela, em que dentro existe outra cena ocorrendo. Vemos o corte em detalhes sendo registrado e projetado em tempo real sobre a capela, e aos poucos a capela é "tingida" de vermelho, pelo sangue do performer que escorre pelo seu peito. Mais um exemplo do corpo ou do detalhe do corpo ganhando uma dimensão estética gigante, já que detalhes do corpo são ampliados e cobrem objetos, aqui uma capela que por si só reage signicamente a cena.

Com recursos parecidos também indico algumas experiências que o performer Rick Seabra ${ }^{56}$ propõem a importância da exploração de texto como origem da imagem poética. A ideia é que a partir de técnicas de escrita e do atiçamento da imaginação se possa criar conteúdo inusitado para a perfomance, evitando os clichês mais comuns utilizados nas artes cênicas.

\footnotetext{
${ }^{56}$ Rick Seabra é artista visual, autor, designer e performer brasileiro e norte- americano, nascido em Washington e criado em Brasília. Se formou pela Parsons School of Design em Nova lorque em Comunicação Visual e tem um mestrado em desenho industrial pela Design Academy Eindhoven na Holanda onde viveu 8 anos. Entre 2002 e 2006 foi artista residente do Kunstencentrum em Mechelen na Bélgica.
} 


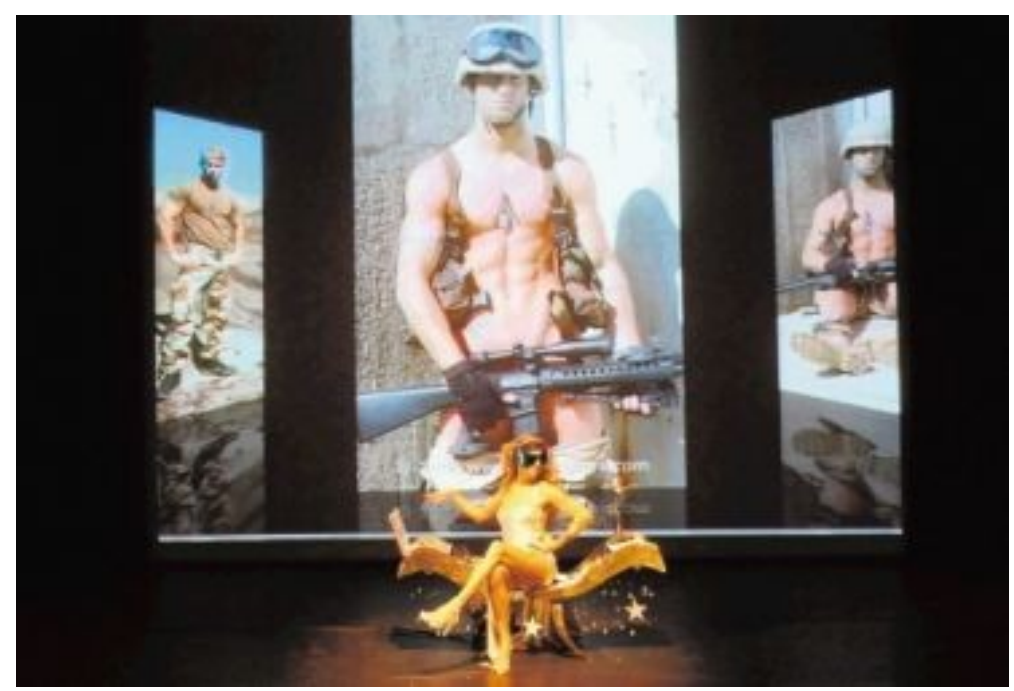

Fig. 89 Cena da performance 'Império, Love to Love You, Baby!', de Rick Seabra, em 2010

Além disso, Ricky instiga sobre o uso de imagens (especialmente o vídeo) em obras, como os projetos em colaboração que já começaram a tomar corpo entre os artistas-bolsistas, materiais gerados durante imersões poéticas.

O espetáculo 'Isadora.Orb, a metáfora final' (Fig.85), do designer e performer Ricky Seabra e da coreógrafa e bailarina Andrea Jabor ${ }^{57}$, explora artisticamente o potencial poético do espaço. É a arte funcionando como uma nova ferramenta para a ocupação do homem no universo. Em cena, através de metáforas de mar e mergulho, profundidade e altura, os artistas encontram-se virtualmente e criam diálogos entre imagens e movimentos. O trabalho flue entre dança, teatro de objetos, contação de histórias e documentário, às vezes se torna um manifesto contra o monopólio das ciências sobre a exploração espacial.

Enquanto Seabra constrói imagens com cartões, fotografias, pratos e discos fazendo projeções ao vivo, Andrea dança dentro dessas imagens na tela, e atua como DJ criando sons para o espaço. O público está sempre ciente de como as imagens são construídas enquanto assistem os artistas envolvidos no processo criativo em cena. Os artistas apresentam obras inéditas ao público, como a primeira canção escrita no espaço e uma replica da única obra de arte que existe na lua.

\footnotetext{
${ }^{57}$ Andrea é esposa de Ricky Seabra e formada pela School for New Dance Development, em Amsterdã (Holanda)
} 


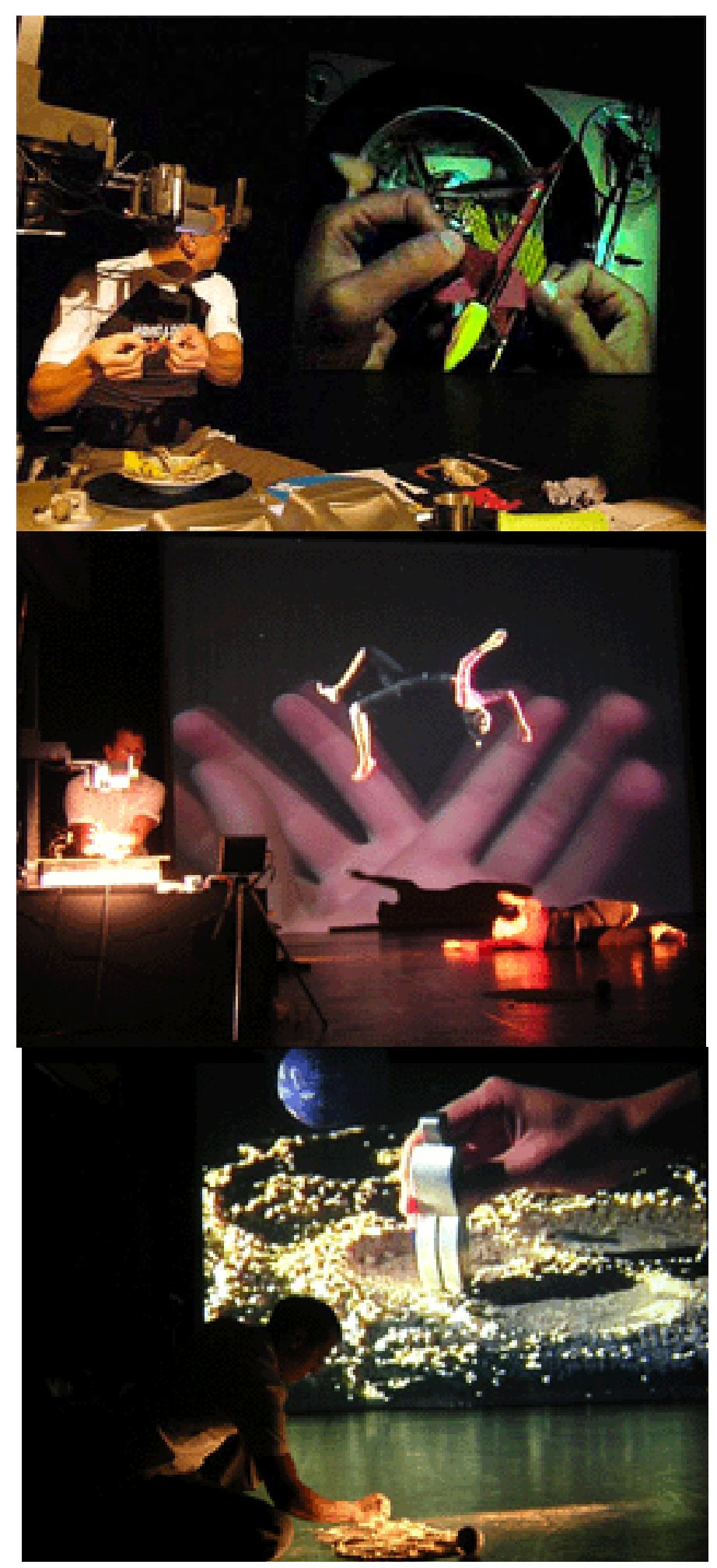

Fig. 90 Cenas da performance 'Isadora.Orb, a metáfora final', de Rick Seabra

A ideia do espetáculo é fruto da tese de mestrado em Desenho Industrial de Ricky na qual propõe a criação de um módulo espacial 'The ISADORA Module', para abrigar artistas a bordo da Estação Espacial Internacional (ISS). O projeto foi apresentado em conferências espaciais na Europa e nos Estados Unidos. Ao investigar a gravidade zero, o 
movimento orbital e a representação do espaço como um lugar novo e inexplorado, os artistas pretendem desvendar 'A Metáfora Final'.

Ainda indico o trabalho de diálogo com imagens tecnológicas no Brasil, o trabalho @.com, do performer amazonense João Fernandes ${ }^{58}$, em que seu 'personagem' dialoga em tempo real com pessoas em chats de sexo, criando uma 'dramaturgia' do acaso, e possibilitando ver imagens de pessoas por todo Brasil em pequenas janelas de imagem e texto que se fricciona com apresentação do performer em tempo real.

O diretor Lenerson Palonini à frente da Cia. Nova de Teatro, com montagens de Beckett, Joyce, Heiner Muller, amparadas pela teatralidade associada as transmissões de imagens tecnológicas ao vivo, sempre em destaque as interações com o corpo do atuante. E ainda os artistas Cris Bierrenbach ${ }^{59}$, como sua performance 'Fala verdade', de 2009, em que de forma interativa os espectadores são convidados, um por vez, a estabelecer um diálogo com a artista e com a plateia, mediado por um detector de mentira (polígrafo) em tempo real e as reações do aparelho são projetadas em tempo real sobre uma tela ao fundo, assim como o close do espectador interrogado.

O performer Shima ${ }^{60}$ com sua obra 'Entrelinhas 60', de 2009, onde os corpos dos espectadores, bem como de Shima, são usados como parte da tela, em que trama-se um processo que embaralha tempos, espaços e dimensões num jogo de telas sobrepostas, entre o efêmero e o perpétuo, o medido e o estimulado, de projetos e reflexões.

Aponto ainda os trabalhos de: Chico Fernandes ${ }^{61}$ e a performance 'Interself $I$ ', de 2003/2006; Fernando Salis ${ }^{62}$ com a obra 'Veni, Veni', de 2009; Tatiana Abitante ${ }^{63}$ com a obra 'De onde vem a cor? Vermelho', de 2009; o performer de suspensão T. Angel ${ }^{64} \mathrm{com}^{\circ}$ a obra 'Inhale Exhale', de 2010; Eduardo $\mathrm{KAC}^{65}$ com a performance 'Time capsule' onde

\footnotetext{
58 João Fernandes, diretor da Companhia de Ideias, de Manaus.

${ }^{59}$ Fotógrafa, repórter e ilustradora em diversos periódicos nacionais, dentre eles Marie Claire, Veja e Criativa. Responsável como diretora de arte da película FilmeFobia, de Kiko Goiffman, de 2007

${ }^{60}$ Shima (Marcio Shimabukuro) nasceu em São Paulo em 1978. É bacharel em Desenho Industrial e realizou residências artísticas na Holanda (2007) e no Japão (2008). Representou o Brasil no 11으 Internacional Performance Art Festival Interackje.

${ }^{61}$ Chico Fernandes trabalha principalmente com performance, vídeo e fotografia. Participa de exposições individuais e coletivas, em museus e galerias como Novembro Arte Contemporânea, Funarte, Itaú Cultural e Museu Nacional de Belas Artes.

${ }^{62}$ Salis é cineasta, ator e professor da Escola de Comunicação da UFRJ.

${ }^{63}$ Abitante é performer, artista plástica e estudante de Artes Visuais da ECA-USP

${ }^{64} \mathrm{~T}$. Angel é performer especializado em body modification e suspensão

${ }^{65}$ Eduardo KAC é artista contemporâneo e pioneiro da arte digital, arte holográfica, arte da telepresença e bioarte; mestrado em artes plásticas School of the Art Institute of Chicago
} 
ele introduz um chip em seu corpo enquanto é transmitido por redes de televisão em 1997 e a pesquisadora Bia Medeiros ${ }^{66}$ com o seu grupo Corpos informáticos, entre outros.

\subsection{Sobre interação entre corpo e imagem tecnológica}

Neste capítulo pretendi refletir acerca da ampliação do entrelaçamento entre o humano e a máquina através das imagens tecnológicas e da disseminação dos dispositivos e da lógica hipertextual que acabou por alcançar o próprio corpo, que é submetido a todo tipo de operações: modelizado por programas computacionais (no domínio do cinema e das experimentações artísticas), entregue ao jogo das aparências e da simulação das identidades nos chats e salas de conversação, conectado a próteses artificiais, vasculhado em seu interior - mas sem ser penetrado - pelas nanotecnologias ou pelos programas de realidade virtual, tornado lugar de implantes biotecnológicos, ou então movido e afetado à distância por meio dos dispositivos - técnicos e artísticos.

A aproximação entre o corpo físico natural e a máquina tecnológica está sendo elaborada nas mais variadas instâncias de pesquisas e estudos. E usar esses recursos tecnológicos não garatem qualidade as artes cênicas, pois se tratam de mais uma ferramenta. Um prótese ao corpo ou uma extensão ao corpo do atuante/performer.

O homem [...] tornou-se uma espécie de "Deus de prótese". Quando faz uso de todos os seus órgãos auxiliares, ele é verdadeiramente magnífico; esses órgãos, porém, não cresceram nele e, às vezes, ainda lhe causam muitas dificuldades [...]. As épocas futuras trarão com elas novos e provavelmente inimagináveis grandes avanços nesse campo da civilização e aumentarão ainda mais a semelhança do homem com Deus. [...] contudo, não esqueceremos que atualmente o homem não se sente feliz em seu papel de semelhante a Deus. (FREUD, 1976, p.111)

O corpo, transformado e desfigurado nas imagens tecnológicas, não traduzem um apelo de deslumbramento tecnológico (típico da pós-modernidade) pois não apresenta uma estética que não seja a de ampliar o olhar sobre o corpo. Certamente é, sem dúvida, o apelo mais evidente às novas formas de 'ver o corpo' outros sentidos de que o corpo, profundamente passa através desses processos tecnológicos a ser marcado e alterado,

\footnotetext{
${ }^{66}$ Bia Medeiros é coordenadora do grupo de Pesquisa Corpos Informáticos. Possui mestrado em estética e doutorado em artes pela Sourbonne, atualmente é professora do departamento de artes visuais da UNB
} 
convoca o espectador a atirar-se na vertigem de um novo ponto de vista.

Produz-se, assim, uma modalidade de olhar que consiste em mostrar um até um corpo deformado e mutilado, pela imagem tecnológica sem que esteja em jogo o dar-se prazer, visto que quem altera o corpo atende a um imperativo categórico formulado nos seguintes termos: é preciso intervir no corpo de todas as maneiras possíveis.

As encenações com forte presença e questões sobre o corpo, secreções, decepamentos, cortes, entre outras modalidades de alterações corpóreas, encontram agora nesses tempos das telas digitais, múltiplas possibilidades de tornar o corpo, para além da body art, para além dos pixels, uma forma que transcende as próprias barreiras biológicas e no campo do pós-humano, as artes cênicas se cercam de possibilidades da dimensão do sublime, quando o corpo é elevado à categoria de obra viva e pulsante sem qualquer enquadramento formal ou ordenação pré-via.

É preciso salientar que essas tecnologias da imagem no corpo não objetiva ser uma arte que retrate o corpo ou uma arte no corpo e sim uma arte que se faz com o corpo, em simbiose, sociedade, amalgamando corpo e técnica e assim configurando-se o acontecimento cênico. 


\section{Considerações Finais}

Ao longo dessa pesquisa tentei mostrar qual é o lugar das imagens tecnológicas na cena hoje. O que muda com a inclusão das linguagens cinematográficas, videográficas e agora a internet nas artes cênicas na contemporaneidade? Quais seriam as contribuições desses cruzamentos entre o teatro, a performance art, a ópera e a dança, quando utilizam as linguagens audiovisuais? A reflexão sobre essas questões foi levantada com base em três pilares de análise: a relação das imagens tecnológicas com o Espaço, o Tempo e, finalmente, o Corpo.

Sempre entendo que o espaço das artes cênicas está entre o fazer e a presença de seus atuantes em diálogo com os avanços do cinema, do vídeo e dos múltiplos recursos de imagem do mundo contemporâneo, incluindo o universo digital da internet. Esse contexto exige novas formas de fazer e receber arte, seja pela simples mistura entre tecnologias de imagem (e aqui me refiro a projeções e à presença de imagens variadas em cena), seja a partir de interatividade e virtualidade, conceitos que se expandiram com o desenvolvimento das artes em geral, e em especial entre as formas do fazer cênico.

Percebemos que essa hibridização das artes cênicas, junto às artes eletrônicas e digitais, vem sendo utilizada para circunscrever uma área de atuação de artistas e grupos que começaram a surgir principalmente a partir dos anos 1930 (com a cineficação) e, a seguir, com o cinema e o vídeo nos anos 1960 (com os happenings e as performances), com a difusão e a facilitação de múltiplos recursos de vídeo nos anos 1980 e 1990 e, nos anos 2000, como a "internetização" da cena. Nesse caso, acontecem as múltiplas possibilidades de interação com recursos de meios de comunicação como as redes sociais, as transmissões via WEB de cenas e personagens tão distantes quanto estranhos aos olhares mais conservadores do teatro.

O que se percebe é que as artes cênicas recuperam seu espaço em plena revolução tecnológica contemporânea, e tentam incorporar e dialogar com outras linguagens artísticas que também se apropriam de recursos tecnológicos e conceitos cientificos. Sob essa perspectiva, torna-se muito difícil falar de "arte" como espelho e filtro da vida sem dialogar com aspectos da tecnologia, como virtualidade, interação e hibridizacão tecnológica. O que não é garantia de qualidade final dos trabalhos. Afinal, 
a tecnologia, bem como as imagens tecnológicas na cena, são apenas mais um recurso de que dispomos hoje. Mas se entendermos que essa ferramenta é rica e contém em si possibilidades múltiplas, provendo recursos cada vez mais acessíveis, que hoje funcionam quase como extensões do corpo, por que nao incorporá-la e adaptá-la ao filtro estético das artes?

Mesmo com a tradicional recusa de novas tecnologias no teatro, e a presença da tradição de mais de cinco mil anos, alguns artistas e grupos advindos, muitas vezes, de outras linguagens, têm infectado as artes cênicas de modo indelével, com novos avatares, espaços virtuais, interatividades e comunicação para além do simples palco do aqui e agora.

À abordagem do tema "arte e tecnologia" cabe sempre uma diferenciação entre aquilo que se considera técnica e o que se considera tecnologia. A técnica é aquilo que cria conhecimento. Portanto, o uso de determinadas técnicas pode ou não implicar um repertório tecnológico, repertório este idêntico a todos os outros tipos de repertórios culturais.

Ainda assim, quando as artes cênicas colocam-se diante das múltiplas possibilidades que os meios digitais proporcionam, um ponto em particular sempre volta a ser questionado: a interatividade com o público. A questão precipita uma polêmica, porque nem sempre a interatividade é a questão mais importante entre as questões relacionadas ao trabalho com mídias digitais. No território cênico, a questão da interatividade muitas vezes é reduzida à técnica pela técnica, e às vezes um espetáculo alimentado com tecnologia pode assumir signos vazios.

As misturas são complexas e nelas existem riscos. Os cruzamentos entre as artes cênicas, ou seja, as artes da presença, e as artes eletrônicas e digitais, que usam a virtualidade, podem alcançar momentos de sublime tecnológico. Mas, se mal empregadas, podem resultar em desastre total, caindo no pobre campo dos modismos.

Aqui tentei indicar exemplos de produções que se negam a entrar nesses modismos. Pelo contrário, os exemplos que cito nessa pesquisa são de importantes artistas que, pioneiros ou contemporâneos, pensam as imagens tecnológicas em cena de forma inteligente, artística e sensível. 
Se o fazer cênico já é tão rico hoje, quando ele se lança no cenário vertiginoso das interatividades digitais suas potências cênicas reinstauram novos paradigmas no imaginário e nas poéticas de recepção. Essas formas de criação com meios digitais foram importantes não tanto pelos recursos quase inesgotáveis que ofereciam - às vezes, até paralisantes para a criatividade -, mas por terem modificado nossas concepções de poesia. Como já mencionei, a poesia é a única palavra capaz de dar conta dessa dimensão imagético-tecnológica que pesquiso aqui, da complexidade e da fluidez da criação artistíco-científica no universo em expansão das novas tecnologias. Estamos fadados à poesia.

No momento em que vemos o cinema e a tecnologia em geral e o teatro como duas linhas de fuga, empobrecemos nosso imaginário, bem como restringimos a possibilidade de crescimento e ampliação das artes da cena. Nesse trabalho, tecnologia e criação cênica formam uma mesma linha de fuga, pois muitas outras linguagens estão fazendo o mesmo.

Hoje em dia, em muitos países da Europa, é impensável a criação de uma escola de artes que não tenha um estreito canal de troca com as novas tecnologias. Acredito que esse seja um caminho sem volta. Claro que podemos sempre optar pelo rústico, pelo tradicional, mas não podemos negar as influências que mudam nosso ser, nossa sociedade e nossa forma de nos entender e entender as relações hoje.

Dessa maneira, investiguei aqui como a tecnologia, através de recursos de projecões e transmissões digitais, pode mudar nossas percepções sensíveis, poéticas e estéticas da cena.

Iniciei a pesquisa investigando as relações entre as imagens tecnológicas e a espacialidade dos espetáculos, tema do primeiro capitulo. Nele pudemos perceber que o potente surgimento do cinema, no início do século $X X$, influenciou o teatro, que inicialmente procurava emprestar características da linguagem cinematográfica, como close-ups, travelings, cortes. Nesse momento, o nome de Meyerhold é decissivo, pois o encenador cria o teatro cineficado tanto internamente (quando não utiliza meios de projeção) quanto externamente, quando usa projeções de imagens e legendas em cena. Dessa maneira, o uso inicial de imagens cinematográficas em cena já possibilita uma modificação no modo de receber o espetáculo teatral. 
As possibilidades cinematográficas também impulsionaram as linguagens do teatro político e documentário de Erwin Piscator, na Alemanha da década de 1930, onde imagens especialmente filmadas eram utilizadas. Ali percebemos as primeiras possibilidades de leitura das imagens tecnológicas em cena. Inicialmente, a possibilidade de "figurativar" um espaço, como na tradição cenográfica do telão típico do teatro clássico, que se extendeu até o século XIX. Não desenvolvi essa função meramente figurativa, de indicar um lugar, por considerá-la óbvia, pobre e pouco complexa, embora ainda seja muito utilizada nos dias de hoje. Acredito que essa forma de utilização figurativa não cria um efeito dialético. Por sinal, era esse efeito que pioneiros como Meyerhold e Piscador buscavam, ou seja, a inclusão das imagens cinematográficas no teatro deveria causar um estranhamento capaz de catapultar a forma de ver a cena, através de justaposição de imagens outras, editadas, que se transformam rapidamente.

Além disso, o uso do cinema na cena pode criar um efeito alargado da realidade apresentada, possibilitando trabalhar a percepção do espectador a partir de várias janelas, e por consequência, criar vários espaços. Esse estranhamento dialético, somado a cenas e, às vezes, a sentidos poéticos e sensíveis, poderia expandir as noções que a encenação buscava e até ampliar as formas de interpretação, já que cenas cinematográficas, somadas a atuações ao vivo, configuram uma reação diferente na leitura final do espectador, pois os dois estímulos, cinematográfico e teatral, resultam num terceiro, que altera os dois anteriores.

Com a chegada dos anos 1960 e 1970, a ampliação da espacialidade da arte via instalações, e depois video-instalações, influenciou não apenas a cenografia contemporânea, mas também as formas de exibição e transmissão de imagens e atmosferas na cena, desde as experiências mais em video, até o momento em que o vídeo abre janelas de espaços paralelos (às vezes fora do campo de visão do público). Desse modo, percebemos que nas novas formas de dialogar com outros espaços, como na tradição da TV e dos sites na internet, temos imagens tecnológicas que "abrem janelas" de outros espaços, que não são possíveis de apreender no campo de visão frontal de um palco italiano, a caixa preta, ou até mesmo de uma galeria, a caixa branca. 
Como pudemos perceber, o cruzamento entre conceitos de virtualidade foram francamente expandidos em várias experiências cênicas analisadas. Apropriando-se de técnicas videográficas de interatividade, ou de cinema digital, ou até mesmo de recursos interativos, o teatro, a dança e as outras artes cênicas expandiram seus recursos, diferentemente das artes não presenciais. Pois, os efeitos de virtualidade somados às presenças físicas e reais do palco resultam em um novo tipo de percepção, trazendo uma "realidade expandida" ou o também chamado "teatro expandido".

Aparentemente novo, o movimento em cena, conseguido hoje através das mudanças rápidas das edições audiovisuais, já era previsto por mestres do passado como R. Wagner, A. Appia, G. Craig e A. Artaud, e experimentado por nomes como E. Piscator e Meyerhold e, posteriormente, por J. Svoboda e J. Polieri. As possibilidades técnicas foram gradativamente se ampliando, até tomarem forma em espetáculos de completa imersão entre imagem tecnológica e atuantes. Porém, estamos na infância desse tipo de cruzamento. Ainda existe muito por vir. As telas se tormam maiores, os recursos de projeção, som e interatividade também crescem rapidamente, e isso pede que os paradigmas de interpretação e encenação também se desloquem no sentido de poderem dialogar com as novíssimas possibilidades que se aproximam.

O teatro documentário encontrou no uso das imagens tecnológicas um perfeito recurso para trazer tempos passados e memórias, fazendo uso de imagens de fatos, reais ou não, e podendo assim, da mesma forma que na tradição do documentário cinematográfico, legitimar e sensibilizar a cena.

Vimos também que, com o crescente avanço tecnológico de projetores e telas, pudemos ter um diálogo maior entre encenação, cenografia e imagens tecnológicas na cena, como no caso de Meyerhold e Svoboda, que traziam possibilidades de elucidação da cena ou desconstruíam a ideia de tela plana (como no caso de Svoboda), ampliando as sensações das imagens projetadas sobre superficies de relevos variados, corpos e formas abstratas. Diferentemente do cinema, as imagens aqui ganham novas texturas, dados os novos suportes da cena, o que amplia e renova as possibilidades de recepção dessas imagens, agora com o acréscimo do signo que a imagem traz, e também do signo de onde a imagem projetada está.

Indico também os riscos negativos do uso de imagens tecnológicas em cena, que muitas vezes podem despontencializar a presença cênica. Por vezes, o "fazer 
cênico", o acontecimento, a presentificação de algo potente, radical e arriscado, são trocados por imagens digitais que suavizam e pacificam o que poderia ser real. São riscos do cruzamento entre linguagens que podem destemperar muitas cenas, indo pelo "caminho mais fácil" e esquecendo que tratamos aqui de potência cênica, ou seja, da arte da presença, cuja potência as linguagens digitais nao podem "matar". A ideia é que nesse cruzamento podemos somar ganhos com a tecnologia e nunca "esfriar" presentificações que só teriam sentido na proximidade, no real ou na interatividade. Confirmo aqui os perigos existentes nessas misturas, e aponto os riscos que são notados com muita frequência, quando o uso das imagens tecnológicas não está devidamente amadurecido e "casado' aos conceitos poéticos e estéticos do projeto cênico.

Para além, e muito além, da idéia antiga do estático telão pintado do século $\mathrm{XIX}$, as novas telas tecnológicas que aqui foram estudadas podem e, com frequência, oferecem um diálogo com a cenografia, ou com os figurinos, compondo nuances e texturas, e até mesmo com os recursos de iluminação. Até porque as imagens projetadas são, primeiramente, luz em cena, e enquanto símbolo da cena podem relacionar-se com ela e colorir seus elementos, conferindo a eles outras nuances e atmosferas.

As imagens tecnológicas podem ampliar as relacões sígnicas da cena, com o uso de estranhamento, onde o que se mostra nas imagens aparentemente não dialoga com o que os atuantes fazem em cena. Esse efeito de sobreposicão ou de justaposição, de estranhamento, pode ser de grande valia para resultados dialéticos ou quando apontam para resultados mais abertos e subjetivos.

Em sua variação pós-moderna, a justaposicão estranhada das imagens tecnológicas constitui uma negativa pelo simulacro. Nesse caso, o estranhamento pode acionar um tormento na contemplação única, redimencionando sentidos e poéticas e, num efeito rizomático, se interligando a outras imagens num sentido de desdobramento de entendimentos. Mesmo com a resitência ao espanto, esse estranhamento aponta para a aparição e o ganho do novo.

Vimos as contribuições das imagens tecnológicas enquanto criadoras de novos espaços, na ampliação de territórios, seja pela transmissão de imagens pregravadas ou de imagens gravadas ao vivo dentro da cena, seja até mesmo por imagens gravadas 
em outros países, e transmitidas via satélite ou web. Com recursos simples hoje disponíveis na seara dos computadores, podemos transmitir e até criar caminhos paralelos ao espetáculo, como sites, blogs e twiters, que podem ampliar as idéias de território em determinado espetáculo. A internetização das artes cênicas é um fato sem volta, haja visto a crescente revolução tecnológica em que vivemos, com as extenções de nosso eu via redes sociais e outros programas de entrelaçamento entre pessoas de todo mundo. Essas formas são incorporadas pelas cenas de hoje, o que altera de forma radical o que entendemos como presença.

Aponto também a importância do uso de imagens digitais em cena como modo de alteração do tempo ou como recurso de resgate de tempos passados, da memória, ou até mesmo de tempos só vividos em termos inconscientes, em pensamentos, devaneios e na loucura. Os recursos das imagens tecnológicas podem resgatar e, ao mesmo tempo, dialogar com atuantes que também se posicionam em tempos cênicos diferentes, criando ambiguidades e ambientes fugidios de percepção temporal. Ao contemplar a subjetividade, os recursos tecnológicos abrem espaços e tempos de experiências muitas vezes particulares entre o espectador e seu tempo. Esse jogo de interrelações, trânsitos e cruzamentos de temporalidades, digitais ou não, abre novas perspectivas de apreensão e carrega em si sentidos múltiplos a cada tempo, a cada dia, a cada temporada e cultura.

No caso das performances de Vjs com música, essa percepcão do tempo está "linkada" aos tempos e ritmos musicais que podem ou não se sobrepor à música e aos sons, ou vice e versa. A impressão e a recepção do tempo estão também ligadas aos níveis de edição e ritmo empregados e apresentados. O contraste entre o tempo artístico apresentado e esses recursos digitais, somados ao tempo da vida de quem assiste, resultam em mudanças de percepcão. Haja visto que nas artes da presença temos em jogo "muitos tempos", e os recursos das imagens tecnológicas podem e devem penetrar e recriar novas noções de tempo.

A interferência de teatralidades e performatividades junto aos recursos digitais de imagem causam sempre um acréscimo de identificação, diálogo, facilitação, estranhamento, sublimação, interrelações, metáforas. Seja no campo teatral, ou no performativo, os recursos e exemplos que apresentei sempre trarão em si imagens, e essas sempre conterão em si conceitos de temporalidade. O tempo embutido em 
todas as imagens editadas, transmitidas ao vivo, criam um cronotopo, ou seja, uma relação de aliança espaço-temporal, permitindo uma metaforizacão temporal. Como acontece nas obras de diretores como Robert Lepage.

Aponto também que muitos recursos sofisticados de imagens tecnológicas já são incorporados e utilizados em produções nacionais, como software sensíveis a interações de movimentos, sons e reacões de público e atuantes, e que já temos toda uma tradição no uso de imagens tecnológicas para além dos modismos ou dos usos "vazios". Indico alguns grupos e artistas que apresentam em seu discurso estético questões importantes e relações poéticas entre tecnologia e corpo, real e virtual, imagem real e imagem tecnológica. O que também mostra um apetite por mudanças e avanços nessa área, sempre incorporando novos modos tecnológicos e novos modos de relação entre a tecnologia analógica/eletrônica e digital.

Confrontando esse homem de hoje, extendido por tantos aparatos tecnológicos numa dinâmica pós-humana, ou do humano expandido, essa tecnologia se abre para diálogos que vão além do atuante e do público, incorporando pessoas fora do "jogo cênico", animais, plantas, teorias filosóficas, antropológicas, sociais, políticas, games, numa orgia rizomática e transdiciplinar que só avança discussões pertinentes ao nosso tempo do aqui e do agora.

Vivemos num tempo em que as relações sociais se tormam cada vez mais distantes e, ao mesmo tempo, mais próximas. As tecnologias da comunicação tem avançado muito na tentativa de juntar pessoas de todo mundo, mas essas mesmas tecnologias tem nos afastado, indissincrasias típicas de nosso tempo. As relações corporais também estão se modificando. Aquilo que se percebe hoje como real pode ser apenas mais um avatar construído e rapidamente desconstruído para a recriação de outros, um labirinto digital onde nos perdemos em tantas telas, em tantos "fios de Ariadne". O uso de imagens tecnológicas também aponta para a natureza cada vez mais caótica dessas relações, podendo servir de instrumento crítico e reflexivo, de painel de análise, de mesa de discussão e problematização das relações entre o mundo real e o mundo virtual/tecnológico.

Nessa pesquisa, aponto vários exemplos de produções artísticas em que a tecnologia mostra, de forma radical, nossas ausências, nossas faltas e nosso despreparo para viver com essas extencões que, ao mesmo tempo que aparentam ser 
obrigadas, são apenas próteses. E mostro também que o uso ostensivo de tecnologia em um trabalho artístico ou cênico pode justamente nos convidar à reflexão sobre a real necessidade desse uso e sobre nosso desencantamento e nosso falso deslumbramento frente aos "progressos conquistados". A tecnologia que escraviza, e que domina, versus a tecnologia aliada e construtiva. Na criação de novos platôs de entendimento e sensibilidade, vamos experimetando as novas ferramentas para descobrir quem somos.

Ao casar a imagem tecnológica ao nosso corpo, como uma nova vestimenta, podemos refletir sobre os limites que ainda nos esperam, como homens e artistas. Para além dos manisfestos, para além das poéticas que tanto buscamos, que a arte possa, junto a esses efeitos tecnológicos, não perder de vista as perguntas que nos guiam nesse labirinto de sensações, estéticas, formas, utilizações, de "inovações aceitáveis" e também não aceitáveis. Pois é só pelo estranho, pelo novo e pelo controverso que podemos nos rever e construir um novo modo de fazer e ver nosssas potências cênicas.

Espero ter apontado algumas reais contribuições das imagens tecnológicas às artes cênicas hoje, trabalhando com o reflexo do passado, as mudanças do presente e as inovações que se seguirão em um futuro cada vez mais próximo. A tradição teatral não precisa ser esquecida. Mas penso que a tradição se refaz a cada dia e que as novas tecnologias, ao mesmo tempo que nos refletem para o bem e para o mal, podem abrir e fazer aflorar a potência de novos fazeres artísticos, de novas perguntas nesse colorido e variado caleidoscópio digital que é a vida dentro ou fora de um palco. 


\section{Relação de Figuras}

Fig.1. Ilustração de Le Bal masqué dirigido por V. Meyerhold, de 1917

Fig.2. Maquete de La Terre cabrée, de Meyerhold, em1923

Fig.3. Representação da montagem La Forêt, de 1924

Fig.4. Espetáculo experimental da Bauhaus, dirigido por Schlemmer, em 1926, com efeitos de iluminação e projeção em jogos de sombras

Fig.5. Ilustração de projeto de Gropius como 'Teatro Total', de 1926

Fig.6. Projeção do perfil do próprio Piscator em cena de Hop là, nous vivons, direção própria em 1927

Fig.7. Fotomontagem do espetáculo Hoppla, wir leben!, por Ernst Toller, de 1927

Fig.8. Cena de Raz-de-marée, dirigido por E. Piscator, no Teatro Volksbuhne, Berlim, em 1926. A projeção do filme insere dramaticidade a ação e faz um jogo complementar entre a cena e a imagem

Fig.9. Projeção com interação em cena em L'Eveil du Printemps, de 1936, direção de M. Kouril, encenada no Teatro Nacional de Praga

Fig.10. Cena de Odisseus, direção de Josef Svoboda

Fig.11. Cena de Odisseus, direção de Josef Svoboda

Fig.12. Ilustração da cenografia de Svoboda para o trabalho L'Instruction, de 1966

Fig.13. Projeções no espetáculo M.T.M. do La Fura dels Baus, em 1994

Fig.14. Cena de M.T.M. de La Fura Del Baus, em 1994

Fig.15. Interação com vídeo no espetáculo F@ust 3.0, de 1998

Fig.16. Interação com vídeo no espetáculo F@ust 3.0, de 1998

Fig.17. Cena do espetáculo $X X X$, do grupo La Fura dels Baus

Fig.18. Cena do espetáculo El martiri de sant Sebastiá, do grupo La Fura dels Baus

Fig.19. Cena do espetáculo $X X X$, do grupo La Fura dels Baus

Fig.20. Montagem da ópera ' $O$ Anel de Nibelungo', de Richard Wagner, pelo grupo catalão La Fura dels Baus sobre direção de cena de Carlos Padrissa e regência de Zubin Mehta

Fig.21. Montagem da ópera 'O Anel de Nibelungo', de Richard Wagner, pelo grupo catalão La Fura dels Baus sobre direção de cena de Carlos Padrissa e regência de Zubin Mehta

Fig.22. Cena de Sonntag, de Karlheinz Stockhausen, direção de Carlus Padrissa, da trupe catalã La Fura Dels Baus

Fig.23. Cena de Tristão e Isolda, dirigido por Peter Sellars com intervenção videográfica de Bill Violla

Fig.24. Cena de Tristão e Isolda, dirigido por Peter Sellars com intervenção videográfica de Bill Violla

Fig.25. Cargo Sofia - traseira de caminhão frigorífico adaptada para acomodação da plateia

Fig.26. Cargo Sofia - traseira de caminhão frigorífico adaptada para acomodação da platéia

Fig.27. Cena do espaço de projeção de imagens para o trabalho Saturday Night Shot, do grupo Gob Squad

Fig.28. Cena do espaço de projeção de imagens para o trabalho Saturday Night Shot

Fig.29. Plateia em vídeo instalação Black Mirror

Fig.30. Imagens de Video Mapping, realizado na cidade de Lion - França, pelo artista François Wunschel 
Fig.31. Imagens de Video Mapping, realizado na cidade de Lion - França, pelo artista François Wunschel

Fig.32. Imagens de Video Mapping, realizado na cidade de Lion - França, pelo artista François Wunschel

Fig.33. Cena de Não sobre o amor, com cenografia de Daniela Thomaz

Fig.34. Trechos de Não sobre o amor com variações cenográficas de Daniela Thomaz

Fig.35. Cenas de 'Yulunga - Poema para um Deus morto', realizado em 2006, na cidade de São José dos Campos, direção de Marcelo Denny

Fig.36. Cenas de 'Yulunga - Poema para um Deus morto', realizado em 2006, na cidade de São José dos Campos, direção de Marcelo Denny

Fig.37. Cena do "Auto de Natal", direção de Marcos Bulhões, cenografia de Marcelo Denny. Acima, tela de projeções em forma triangular que dialogavam com imagens ao vivo, da encenação, e também com imagens previamente gravadas

Fig.38. Cena do personagem Mefistófeles projetado por vários projetores, simultaneamente, nos muros do Forte dos Reis Magos, em Natal, para o espetáculo "Devorando Fausto", em 2008, direção de Marcos Bulhões, direção de arte de Marcelo Denny

Fig.39. Cena de espetáculo Glow, do grupo Chunk Move, de 2010

Fig.40. Cena de espetáculo Mortal Engine, do grupo Chunk Move, de 2008

Fig.41. Espetáculo de dança em 3D 'Stravinsky's The Rite of Spring' da dançarina Julia Mach e direção de Klaus Obermaier, de 2011

Fig.42. Cena do happening Variations VII, de 1965, com John Cage, David Tudor, Gordon Mumma Caroline Brown, Merce Cunningham, Barbara Dilley

Fig.43. Concerto for T.V. Cello \& Videotapes, de Nan Jun Paik e Charlotte Moorman

Fig.44. Cena de Lipsink, direção de Robert Lepage

Fig.45. Cena de 'Os sete afluentes do Rio Otta', direção de Robert Lepage

Fig.46. Cena de 'Os Sete Afluentes do Rio Ota', montagem brasileira com direcão de Monique Gardenberg

Fig.47. Cena de Lipsink, direção de Robert Lepage

Fig.48. Cena de Elsenor, de Robert Lepage

Fig.49. Cena da ópera Die Walküre, dirigido por Robert Lepage, que estreou em abril de 2010

Fig.50. Cena de La Damnation de Faust, ópera de Hector Berlioz, dirigida por Robert Lepage, em 2010

Fig.51. Cena de 'Le projet Andersen', direção de Robert Lepage, de 2008

Fig.52. Cena do espetáculo 'PFdRSFi - Pequenas frestas de ficção sobre realidade insistente', de 2007

Fig.53. Montagem da Cia. Phila 7: What's wrong with the world - elencos em continentes diferentes encenaram simultaneamente o mesmo texto e interagiram uns com os outros por imagens

Fig.54. Cena da série Play on Earth

Fig.55. Cena de 'Festa de Separação', com direção de Luiz Fernando 'Fepa', em 2010

Fig.56. Cena de 'Devorando Quixote', direção de Marcelo Denny e Marcio Pimentel, em 2008

Fig.57. Espetáculo de fantasmagoria dirigido por Thomas William Robertson que projetava fantasmas com o uso de lanternas mágicas e espelhos

Fig.58. Fantasmagoria de Etienne-Gaspard Robertson, em Mémories récreatives 
scientifiques et enecdotiques, frontoscópicio, Paris, 1831

Fig.59. Conhecida como "Deusa da Luz", Loïe Fuller não tinha formação em dança, mas os movimentos feitos por ela foram inovadores e fez com que se tornasse um marco na história do cinema, figurino e da dança

Fig.60. Desenho de cena de Robert Edmond Jones para a Ópera The Hand of Fate, 1930 Fig.61. Cena da performance Telematic Dreaming, de Paul Sermon, projeto iniciado em 1992

Fig.62. Cena da instalação The Influence Machine, realizada no Madison Square Park, em Nova York

Fig.63. Cena da instalação The Influence Machine, realizada no Madison Square Park, em Nova York

Fig.64. Cena da instalação The Influence Machine, realizada no Madison Square Park, em Nova York

Fig.65. Cena da instalação Subemerged, de 2008

Fig.66. Cena de 'Os cegos', com direção de Denis Marleau, em 2009

Fig.67. Cena de 'Os cegos', com direção de Denis Marleau, em 2009

Fig.68. Cena de 'Une fête pour Boris', direção de Denis Marleau, em 2010

Fig.69. Cena do espetáculo do Studio Azzuro 'Partecipare La belleza', de 2009

Fig.70. Cena da performance Exoskeleton Cyborg Frictions, de 1999

Fig.71. Cena da performance-palestra com Sterlac, de 2003

Fig.72. Cena da performance 'Epizoo', de Marcel-li Antunez Roca, de 1999

Fig.73. Cena da performance Protomembrana, de Marcel-li Antunez Roca, de 2006

Fig.74. Cena de 'Biped', de Merce Cunningham, de 1999

Fig.75. Cena de 'Biped', de Merce Cunningham, em 1999

Fig.76. Cena da coreografia 'The Frozen Ones', de 2004

Fig.77. Cena da coreografia Mini@tures, do grupo francês Mulleras

Fig.78. Cena da vídeo performance 'Marca Registrada', de Leticia Parente, de 1975

Fig.79. Proposta de videocriaturas de Donasci

Fig.80. Proposta de videocriaturas de Donasci

Fig.81. Proposta de videocriaturas de Donasci

Fig.82. Cena da performance $K A$ - $A$ sombra da alma, de Renato Cohen

Fig.83. Cena do espetáculo 'Embodied Voodoo Game', do grupo Cena 11, de 2011

Fig.84. Cena do espetáculo Skinnerbox, do Cena 11, em 2009

Fig.85. Cena do espetáculo Skinnerbox, do Cena 11, em 2009

Fig.86. Cena do espetáculo Skinnerbox, do Cena 11, em 2009

Fig.87. Cena de 'Devorando Quixote', de 2008

Fig.88. Cena de 'Julio Cesar', com a Societas Raffaello Sanzio com direção de Romeo Castelucci, em 1997

Fig.89. Cena da performance 'Império, Love to Love You, Baby!', de Rick Seabra, em 2010

Fig.90 Cenas da performance 'Isadora.Orb, a metáfora final', de Rick Seabra 


\section{Referências bibliográficas}

Obras sobre Artes / Artes Cênicas e Tecnologia

ABAD, Mercedes (org). La Fura dels Baus 1979-2004, Barcelona, Electa, 2004.

ARANTES, Priscila. Arte e Mídia - Perspectivas da Estética Digital, São Paulo, Editora SENAC, 2005.

BAUDRILLARD, Jean. Tela-total- Mito-ironias da era do virtual e da imagem, São Paulo, Editora Sulina, 1997.

BAUGH, Christopher. Theatre, Performance and Technology, New York, Palgrave, 2005.

BEIGUELMAN, Giselle. Link-se arte/mídia/política/cibercultura, São Paulo, Editora Peirópolis, 2005.

BERGHAUS, Gunter. Avant-garde performance-Live events and electronic technologies, London, Palgrave, 2005.

BIRRINGER, Johannes. Performance, technology e science, New York, PAJ Publications, 2008.

. Media \& Performance - along the border, New York, PAJ Books, 1998.

CHAPPLE, Freda. Intermediality in Theatre and Performance, New York, Rodopi, 2006.

COHEN, Renato. Performance como Linguagem, São Paulo, Editora Perspectiva, 1989.

. Work in Progress na Cena Contemporânea, São Paulo, Editora Perspectiva, 2004.

DAVIDSON, Andréa. Danse et nouvelles tchnologies, Paris, Bains, 2006.

DERY, Mark. Velocidad de escape, Madrid, Ediciones Siruela, 1992.

DIXON, Steve. Digital Performance, A history of new media in theater, dance, performance art, and installation, London, The MIT Press, 2007.

DOMINGUES, Diana (org) Arte e vida no século XXI, Tecnologia, ciência e criatividade, São Paulo, Editora UNESP, 2003.

. A Arte no século XXI - A humanização das tecnologias, São Paulo, Editora UNESP, 1997.

Arte, Ciência e tecnologia - passado, presente e desafios, São Paulo, Editora UNESP, Itaú Cultural, 2007. 
FRY, Maxwell. A arte na era da máquina, São Paulo, Editora Perspectiva, 1976.

GIANNETTI, Claúdia. Estética Digital-Sintopia da arte, a ciência e a tecnologia, Belo Horizonte, Editora C/Arte, 2006.

GIESEKAN, Greg. Staging the screen, the use of film and vídeo in theatre, Palgrave, 2007.

GOSCIOLA, Vicente. Roteiro para as novas mídias, São Paulo, Editora Senac SP, 2003.

GOLDBERG, Roselee. A Arte da performance, do Futurismo ao presente, São Paulo, Martins Fontes, 2006.

Performance Live Art Since the 60s. London, Thames \& Hudson, 2004.

GLUSBERG, Jorge. A Arte da Performance, São Paulo, Editora Perspectiva, 2003.

GRAU, Oliver. Arte Virtual da ilusão à imersão, São Paulo, Editora UNESP, Editora SENAC, 2003.

KAYE, Nick. Multi-Media-video-installation-performance, London, Arts \& Humanities Research Council, 2007.

LACHAUD, Jean-Marc. Arts et Nouvelles Technologies, Paris, L’Harmattan, 2007.

LAVIGNE, Emma. Electric Body Lê Corps em Scéne, Paris, Beaux Arts, 2003.

LEHMANN, Hans-Thies. Teatro Pós-dramático, São Paulo, COSACNAIFY, 2007.

LEMOS, André. Cibercultura-Tecnologia e vida social na cultura contemporânea, São Paulo, Editora Sulina, 2002.

JENKINS, Henry. Cultura da convergência, São Paulo, Editora Aleph, 2006.

MACHADO,Arlindo. Arte e mídia, Rio de Janeiro, Zahar, 2007.

MANNONI, Lurent. A grande arte da luz e da sombra, São Paulo, Editora UNESP, Editora SENAC, 2003.

MELLO, Christine. Extremidades do vídeo, São Paulo, Editora SENAC, 2008.

- Marcelina - Revista do Mestrado em Artes Visuais Faculdade Santa

Marcelina, São Paulo. 2008

NICOLÒ, Daniela. Lo vivo nelle cose-Appunti di viaggio da 'Rooms" a Pasolini, Milano, Ubulibri, 2006.

PARENTE, André (org) Imagem Máquina a era das tecnologias do virtual, São Paulo, Editora 34, 2004.

PIZZO, Antonio, Teatro e mondo digitale, Veneza, Marsilio, 2003. 
ROCA, Marcel-lí Antúnez. Marcel-Lí Antunez Roca - Performances, Objects \& Drawings, Espanha, 1998.

Protomenbrana, Espanha, 2008.

RUSH, Michael. Video art, London, Thames \& Hudson, 2007.

. Novas mídias na arte contemporânea, São Paulo, Martins Fontes, 2006.

SABBATTINI, Nicola. Pratique Pour Fabriquer Scenes et Machines de Theatre, Paris, Dês et Calendes la Bibliotheque dês Arts.

SALIS, Fernando. Performance presente futuro, vol II, Rio de Janeiro, Aeroplano, 2009.

SANTAELLA, Lúcia. Culturas e artes do pós - humano, da cultura à cibercultura, São Paulo, Paulus, 2003.

. Mídias e artes-Os desafios da arte no início so século XXI, São Paulo,

Editora UNIMARCO, 2002.

SANTANA, Ivani. Dança na cultura digital, Salvador, Bahia, EDUFBA, 2006.

. Corpo Aberto, Cunningham, dança e novas tecnologias, São Paulo, EDUC,

FAPESP, 2002.

SMITH, Marquard. Sterlarc The Monograph, London, The Mit Press, 2005.

SPADONI, Cláudio. Plessi II Teatro Eletrônico Della Memória, Bologna, Edizioni Gabriele Mazzota, 2001.

TRIBE, Mark. New media art, Lisboa, TASCHEN, 2007.

VALLIAS, André. Rumos (do) jornalismo cultural, São Paulo, Summus, 2007.

VALLIN, Béatrice Picon(org) A arte do teatro, entre tradição e vanguarda. Meyerhold e a cena contemporânea, Rio de Janeiro, 2006.

. La Scène et lês images, Paris, CNRS Editions, 2004.

VALLIN, Béatrice Picon(org) Lês Écrans sur la scène, Paris, Editions LÀge d`Homme, 1998.

VENTURELLI, Suzete, Arte-espaço, tempo e imagem, Brasília, Editora UnB, 2004.

Outras obras de referência

ABRANTES, Bebeto. Multiplicidade, Rio de Janeiro, Aeroplano, 2009.

AGAMBEM, Giorgio. O que é contemporâneo? E outros ensaios, Chapecó, ARGOS, 2009.

AMARAL, Ana Maria. Teatro de Formas Animadas.São Paulo: EDUSP, 1996. 
ANNE, Ubersfeld. Semiótica Teatral, Madrid, Cátedra / Univerdad de Murcia, 1989.

APPIA, Adolphe. A Obra de Arte Viva. Lisboa, Ed. Arcádia.

AUGUSTO, Maria de Fátima. A montagem cinematográfica e a lógica das imagens, São Paulo, AnnaBlumme, 2004.

BABLET, Dennis et alikês Revolutions Sceniques du XXe Siecle. Paris, Societe Internationale D’Arte XXe Siecle, 1975.

BAIXAS, Joan. Escenes de L’Imaginari, Barcelona, Disputació de Barcelona, 1998.

BERTHOLD, Margot. História Mundial do Teatro, São Paulo, Editora Perspectiva, 2000.

BILKOVÁ, Marie. A Mirror of World Theatre II, Praga, Theatre Institute Prague, 2003.

BOGATYREV, P. et ali O Signo Teatral - A Semiologia Aplicada à Arte Dramática, Porto Alegre, Editora Globo, 1977.

BONNET, Eric. Théâtre et Arts plastiques- Entre Chiasmes et Confluences, Le MontHouy, Presses Universitaires de Valenciennes, 2002.

BOUSSO, Vitória Daniela. Metacorpos, São Paulo, Paço das Artes, 2003.

BROOK, Peter. O Teatro e seu Espaço, Petrópolis, Vozes, 1970.

CARLSON, Marvin. Teorias do Teatro, São Paulo, UNESP, 1997.

CASTANHEIRA, José Manoel. Scénographies 1973-1993, Lisboa-paris, Nobilis, 1993.

CASTELLUCCI, Romeo. Epitah, Milão, Ubulibri, 2003.

COPEAU, Jacques et alilnvestigaciones Sobre el Espacio Scenico, Madid, Alberto Corazon Editor, 1970.

COTTON, Gustave. Le Théâtre en France au Moyen Age. Paris, Press Universitaires de France, 1948.

CYPRIANO, Fabio. Pina Bausch, São Paulo, Cosac Naify, 2005.

DAVIS, Tony. Stage Design, London, RotoVision, 2001.

DE LAGE, Christophe Raynaud. Intérieur Rue - 10 ans de Théâtre de Rue, Paris, Éditions Theatrales, 2000.

DELEUZE, Gilles. A Imagem-tempo, São Paulo, Editora Brasiliense, 1990.

. A Imagem-movimento, Lisboa, Assírio \& Alvim, 2009.

DEMPSEY, Amy. Estilos, Escolas \& Movimentos, São Paulo, Casac \& Naify,2003.

DONDIS, Donis A. Sintaxe da Linguagem Visual, São Paulo, Martins Fontes, 2003. 
ECHENIQUE, Maria Mercedes Marambio. Espacio sobre Espacio Las Oportunidades que Entrega la Instalacíon Plástica al Trabajo Del Diseñador Teatral, Santiago, Universidade de Chile, 2003.

EISENSTEIN, Sergei. A forma do filme, Rio de Janeiro, Jorge Zahar Editor, 2002.

FABRINI, Ricardo Nascimento. A Arte Depois das Vanguardas, Campinas, Editora da UNICAMP, 2002.

FAGIOLO, Maurizio. La Scenographie Dalle Sacre Rappresentazioni al Futurismo, Firenze, Sansoni, 1973.

FELINTO, Erick. A religião das máquinas-ensaios sobre o imaginário da cibercultura, Porto Alegre, Sulina, 2005.

FONTANEL, Beátrice. O Teatro no Mundo. São Paulo, Editora Melhoramentos. 1995 GOODWIN, John. British Theatre Design the Modern Age, London, Weidenfeld \& Nicolson London, 1980.

GILDER, Rosamond. Contemporary Stage Design-USA, New York, International Theatre Institut of The Unidted States, 1974.

GRIFFITHS, Trevor R. Stagecraft, the Complete Guide to Theatrical Practive, Oxford, Phaidon, 1982.

INGARDEN, Bogatyrev. O Signo Teatral, Porto Alegre, Editora Globo, 1977.

IRVIN, Poliiy. Directing for the Stage, London, RotoVision, 2003.

JUNG, C. G. O Homem e seus Símbolos, São Paulo, Nova Fronteira.

Yoshida, Chiaki. Kabuqui, Japão, Color Books, 1983.

KOUDELA, Ingrid D. Heiner Müller - 0 espanto no teatro, São Paulo, Editora Perspectiva, 2003.

LATIL, Pierre de. 0 pensamento artificial-Introdução à cibernética, São Paulo, IBRASA, 1968.

LEBEL, Jean Jaques. Happenning, Rio de Janeiro, Editora Expressão e Cultura, 1969.

LECERCLE, Jean-Jacques. Frankenstein - Mito e filosofia, Rio de Janeiro, José Olimpio Editora, 1991.

LÉVY, Pierre. O que é virtual?, São Paulo, Editora 34, 1996.

LIMA, Mariângela Muraro Alves de (org) Imagens do Teatro Paulista, São Paulo, Imprensa Oficial do Estado, 1985.

MACIEL, Kátia. Transcinemas, Rio de Janeiro, Contra Capa Livraria, 2009. 
MAHONY, O Marie. Cyborg - the man machine, London, Thames \& Hudson, 2002.

MANTOVANI, Anna. Cenografia, São Paulo, Editora Ática, 1989.

MEDEIROS, lone de. Grupo Oficcina Multimédia, Belo Horizonte, I.T. Medeiros, 2007.

MEDEIROS, Maria Beatriz. Espaço e performance, Brasília, Universidade de Brasília, 2007.

. Tempo e performance, Brasília, Universidade de Brasília, 2007.

MIRALLES, Alberto. Novos Rumos do Teatro, Rio de Janeiro, Salvat Editora, 1979.

MOLDOVEANU, Mihail. Composition, Lumière et Couleur dans le Théâtre de Robert

Wilson-Léxpérience Comme Mode de Pensée, Paris, Alain de Gourcuff Éditeur, 2001.

NASCIMENTO, Otávio do. Videocriaturas - Análise de videoperformances realizadas entre 1980 e 2001, Escola de Comunicação e Artes da Universidade de São Paulo, São Paulo, 2002.

PAVIS, Patrice. A Análise dos Espetáculos, São Paulo, Editora Perspectiva, 2003. . Dicionário de Teatro. São Paulo, Editora Perspectiva. 2001.

. A encenação contemporânea - origens, tendências, perspectivas, São

Paulo, Editora Perspectiva, 2010.

PELEGRINI, Sandra (org) Dimensões da Imagem, Maringá, UEM, 2005.

PERES, Francisco Serpa. O corpo tecnológico - intersecções entre performer e mídias. Escola de Comunicações e Artes da Universidade de São Paulo, 2008

PIRES, Beatriz Ferreira. O Corpo como Suporte da Arte, São Paulo, Editora SENAC, 2005.

POLIERI, Jacques. Scénographie, Sémiographie, texts et réalisations, Paris, Denoël/ Gonthier, 1971.

RANGEL, Otávio. Técnica Teatral, Rio de Janeiro, S.E., 1948.

RIEMSCHNEIDER, Burkhard, Arte Actual, Madrid, Taschen, 2001.

PÉRIER, Jean-Marie. Le Rêve, Un Spectacle créé par Dragone, Paris, Flammarion, 2005.

RATTO, Gianni. Antitratado de Cenografia, São Paulo, Editora SENAC, 1999.

RODRIGUES, Mauro Roberto. O Espaço do teatro: Estudos e Registros do Espaço Teatral de Tipo Múltiplo, São Paulo, Dissertação de Mestrado ECA-USP, 1999.

ROUBINE, Jean Jacques. A Linguagem da Encenação Teatral - 1880-1980. Traducão e apresentação de Yan Michalski, Rio de Janeiro: Zahar, 1982.

RUDIGER, Francisco. Cibercultura e pós-humanismo, Porto Alegre, ediPUCRS, 2008. 
Introdução às teorias da cibercultura, São Paulo, Editora Sulina, 2007.

SÁ, Nelson de. Diversidade Um guia para o teatro dos anos 90, São Paulo, HUCITEC, 1997.

SANTAELLA, Lucia. Culturas e artes do pós-humano, da cultura à cibercultura, São paulo, Paulus, 2003.

SCHENBERG, Mário. Pensando a Arte, São Paulo, Nova Stella, 1988.

SMITH, Romm. American Set Design 2, New York, Theatre Communications Group, 1991.

SONREL, Pierre. Traité de Scénographie. Paris-França, Odette Lieutier, 1943.

SOUTHERN, Richard. Manual Sobre a Montagem Teatral - Para Amadores e Profissionais, São Paulo, Moraes Editores.

SOUZA, Newton de. A Roda, a Egrenagem e a Moeda-Vanguarda e espaço no teatro de Victor Garcoa no Brasil, São paulo, Editora UNESP, 2003.

STANISLAVSKI, Constatin. A Criação de um Papel. Rio de Janeiro, Editora Civilização Brasileira, 1972.

STRANGRET, Lech. Tadeusz Kantor - L’Escena de La Memória, Madrid-Barcelona, Fundacion Arte Y tecnologia, 1997.

UBERSFELD, Anne. Lire le Théâtre II, L’école du Spectateur,Paris, Belin Sup Lettres, 1996.

VAZQUEZ, Adolfo Sánchez. Convite à Estética, Rio de Janeiro, Civilização Brasileira, 1999.

VILLEGAS, Juan. Del Escenario a la Mesa de la Critica. Barcelona.McNaughton \& Gunn Inc, 1997.

VINCENDON, Daniel. As máquinas vivas, Brasil, Hemus, 2007.

WOOD, Paul. Arte Conceitual, São Paulo, Casac \& Naify, 2002. 